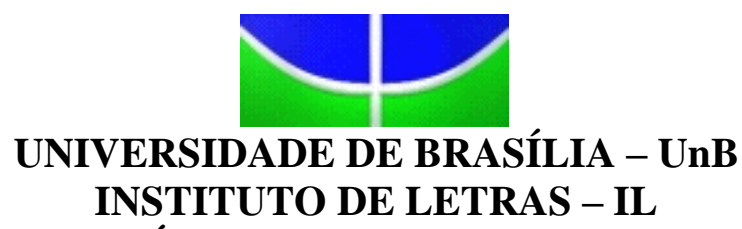

DEPARTAMENTO DE LÍNGUAS ESTRANGEIRAS E TRADUÇÃO - LET PROGRAMA DE PÓS-GRADUAÇÃ̃ EM ESTUDOS DE TRADUÇÃO POSTRAD

\title{
LEGENDAS E INTERMEDIAÇÃO: \\ HUMOR E SENSIBILIDADE EM TRADUÇÃO
}

\author{
CLÁUdia SUZANO DE ALMEIDA
}

DISSERTAÇÃO DE MESTRADO EM ESTUDOS DA TRADUÇÃO

BRASÍLIA - DF

AGOSTO/2015 
UNIVERSIDADE DE BRASÍLIA - UnB

INSTITUTO DE LETRAS - IL

DEPARTAMENTO DE LÍNGUAS ESTRANGEIRAS E TRADUÇÃO - LET

PROGRAMA DE PÓS-GRADUAÇÃO EM ESTUDOS DE TRADUÇÃO POSTRAD

\author{
LEGENDAS E INTERMEDIAÇÃO: \\ HUMOR E SENSIBILIDADE EM TRADUÇÃO
}

CLÁUDIA SUZANO DE ALMEIDA

ORIENTADOR: PROF. DR. MARK DAVID RIDD

DISSERTAÇÃO DE MESTRADO EM ESTUDOS DA TRADUÇÃO

BRASÍLIA/DF

AGOSTO/2015 


\section{REFERÊNCIA BIBLIOGRÁFICA E CATALOGAÇÃO}

ALMEIDA, Cláudia Suzano. Legendas e intermediação: humor e sensibilidade em tradução. Brasília: Departamento de Línguas Estrangeiras e Tradução, Universidade de Brasília, 2015, 168 f. Dissertação de mestrado.

Documento formal, autorizando reprodução desta dissertação de mestrado para empréstimo ou comercialização, exclusivamente para fins acadêmicos, foi passado pelo autor à Universidade de Brasília e acha-se arquivado na Secretaria do Programa. O autor reserva para si os outros direitos autorais, de publicação. Nenhuma parte desta dissertação de mestrado pode ser reproduzida sem a autorização por escrito do autor. Citações são estimuladas, desde que citada a fonte.

\section{FICHA CATALOGRÁFICA}

\footnotetext{
Almeida, Cláudia Suzano

Legendas e intermediação: humor e sensibilidade em tradução / Cláudia Suzano de Almeida - Brasília, 2015.

$168 \mathrm{f}$.

Dissertação de mestrado - Programa de Pós-Graduação em Estudos da Tradução (POSTRAD) do Departamento de Línguas Estrangeiras e Tradução (LET) da Universidade de Brasília (UnB).

Orientador: Mark David Ridd.

1. Tradução. 2. Legendagem. 3. Humor. 4. Linguagem sensível. I. Universidade de Brasília. II. Legendas e intermediação: humor e legendagem em tradução.
} 
UNIVERSIDADE DE BRASÍLIA - UNB

INSTITUTO DE LETRAS - IL

DEPARTAMENTO DE LÍNGUAS ESTRANGEIRAS - LET

PROGRAMA DE PÓS-GRADUAÇÃ̃O EM ESTUDOS DE TRADUÇÃO POSTRAD

\author{
LEGENDAS E INTERMEDIAÇÃO: \\ HUMOR E SENSIBILIDADE EM TRADUÇÃO
}

CLÁUDIA SUZANO DE ALMEIDA

DISSERTAÇÃO DE MESTRADO SUBMETIDA AO PROGRAMA DE PÓS-GRADUAÇÃO EM ESTUDOS DA TRADUÇÃO DA UNIVERSIDADE DE BRASÍLIA - UNB, COMO PARTE DOS REQUISITOS NECESSÁRIOS PARA A OBTENÇÃO DO TÍTULO DE MESTRE EM ESTUDOS DA TRADUÇÃO.

APROVADA POR:

Prof. Dr. Mark David Ridd, UnB (orientador)

Prof. Dr. Lauro Maia Amorim, UNESP (examinador externo)

Prof. ${ }^{a}$ Dr. ${ }^{a}$ Alessandra Ramos de O. Harden, UnB (examinadora interna)

Prof. ${ }^{a}$ Dr. ${ }^{\text {a }}$ Soraya Ferreira Alves, UnB (suplente)

BRASÍLIA, 7 DE AGOSTO DE 2015 


\section{DEDICATÓRIA}

Dedico esse trabalho a você, leitor, pois nada do que se escreve tem vida se não houver alguém para ler.

Dedico também a meu pai (in memoriam), que estaria/está bem orgulhoso agora. 


\section{AGRADECIMENTOS}

Ao meu orientador, Professor Mark David Ridd: eu, sempre tão cheia de palavras, não tenho nenhuma para expressar meu reconhecimento por seu apoio inabalável, motivação inesgotável, inspiração imensurável, e por não desistir; meu agradecimento é $\infty$.

À professora Germana Henriques Pereira de Sousa, pelo incentivo constante e entusiasmo contagiante; e pela energia admirável dos queridos que fizeram comigo essa caminhada: Clarissa, Gabriela, Fernanda, Jakeline, Lorena, Agnes, Patrícia e Rodrigo obrigada, vocês fizeram e fazem a diferença.

À minha mamy querida, por estar sempre presente e atenciosa.

Ao Luiz Cláudio, pelas idas e, principalmente, pelas vindas; e às três lindas companheirinhas das minhas madrugadas insones, e de todos os meus dias.

Ao meu amigo Uver, pelo estímulo - essencial e fundamental - nessa história.

Aos amigos Danny, Valeska, e Dani, por ser; e estar.

Ao Thiago, por me trazer de volta ao centro.

Aos queridos Jorge Díaz-Cintas e Frederic Chaume, catedráticos da legendagem e da dublagem, que tive o privilégio de conhecer recentemente; vocês são fonte de inspiração. 


\section{RESUMO}

A legendagem, no âmbito da tradução audiovisual, é a chamada tradução diagonal, que apresenta, por escrito, o ato da fala. As legendas evidenciam os diversos elementos linguísticos e culturais presentes nesse ato, com todo o arcabouço de ideias, valores, e crenças de uma língua. Partindo do pressuposto que as legendas explicitam as escolhas tradutórias que refletem esses elementos, este trabalho consiste no estudo das instâncias de humor e linguagem sensível na legendagem de comédias brasileiras, em DVDs com legendas em inglês. Usando como base teórica para identificar e analisar as decisões tradutórias a Teoria do Script Semântico de Humor, de Victor Raskin, a Teoria Geral do Humor Verbal, de Raskin e Attardo, a Teoria do Escopo, de Reiss e Vermeer e a Teoria Funcionalista de Christiane Nord, assim como a definição das práticas de tradução para legendas de Jorge Díaz-Cintas e os procedimentos e estratégias tradutórias de Heloísa Barbosa e Henrik Gottlieb, procurou-se descrever os tipos de humor e linguagem sensível nas legendas de comédias brasileiras e analisar as estratégias nelas adotadas e efetivadas.

Palavras-chave: Tradução, legendagem, humor, linguagem sensível. 


\begin{abstract}
Subtitling, within the scope of audiovisual translation, is the so-called diagonal translation, which presents, in written form, a speech act. Subtitles convey the various linguistic and cultural elements found in this act, together with the framework of ideas, values and beliefs of a given language. Assuming that subtitles set forth the translational choices that reflect these elements, this work aims at analyzing occurrences of humor and sensitive language in Brazilian comedies, in DVDs with English subtitles. To identify and investigate the translational choices, the theoretical framework used was Victor Raskin's Script-based Semantic Theory of Humor, Raskin and Attardo's General Theory of Verbal Humor, Reiss and Vermeer's Skopostheorie and Christiane Nord's Functionalist Theory, as well as the definition and subtitling practices by Jorge DíazCintas and translation procedures and strategies by Heloísa Barbosa and Henrik Gottlieb, with the purpose of outlining the types of humor and sensitive language in the subtitles of Brazilian comedies and analyzing the chosen strategies.
\end{abstract}

Key words: Translation, subtitling, humor, sensitive language. 


\section{LISTA DE FIGURAS}

Figura 1. Proposta de categorização dos procedimentos técnicos da tradução, de Heloísa Gonçalves Barbosa .57

Figura 2. Processo de Tradução Centrada no Usuário .59

Figura 3. Tradução diagonal (GOTTLIEB, 2004) .62

Figura 4. Estratégias de tradução para legendagem de elementos culturais

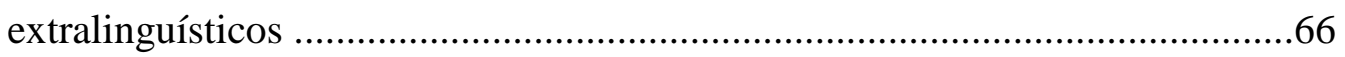

Figura 5. Capa do DVD do filme Lisbela e o prisioneiro .............................................74

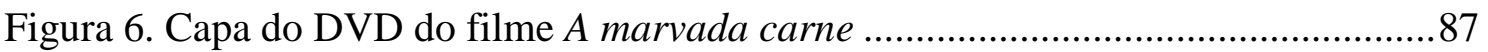

Figura 7. Capa do DVD do filme Quincas Berro D'Água ...........................................95

Figura 8. Capa do DVD do filme $O$ auto da Compadecida ......................................... 108

Figura 9. Capa do DVD do filme Cine Holliúdy .......................................................... 119

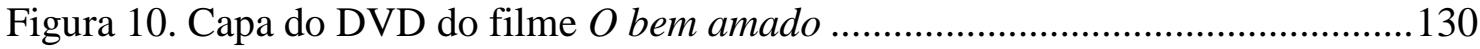

Figura 11. Capa do DVD do filme E aí... сотеu? ................................................... 141 


\section{SUMÁRIO}

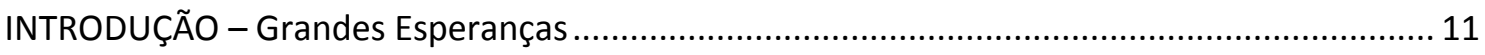

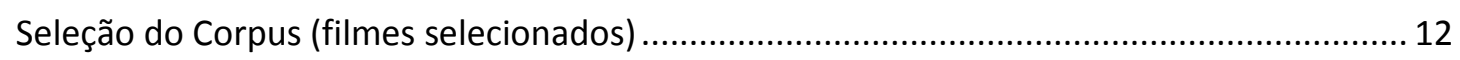

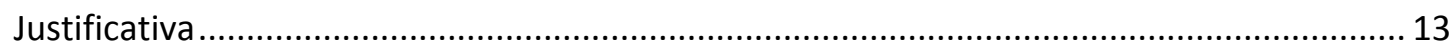

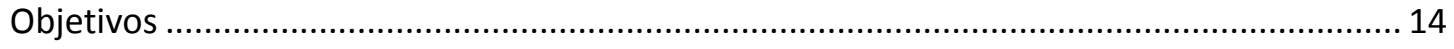

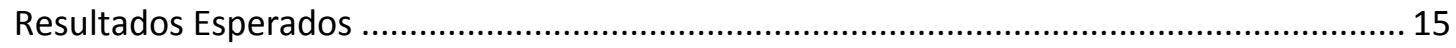

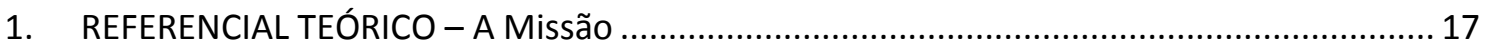

1.1. Humor... - Apertem os Cintos, o Piloto Sumiu! ........................................................ 19

1.1.1. Teoria dos Dois Scripts / Teoria Geral do Humor Verbal / Teoria OntológicoSemântica do Humor..................................................................................................... 22

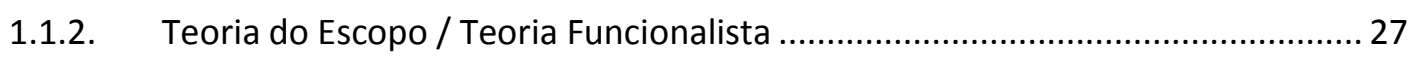

1.2. ... e Sensibilidade... - Razão e Sensibilidade ................................................................ 37

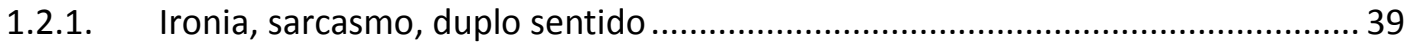

1.2.2. Preconceito, tabu, linguagem erótica ……........................................................ 44

1.3. .... na Tradução - Muito Além do Jardim ...................................................................... 49

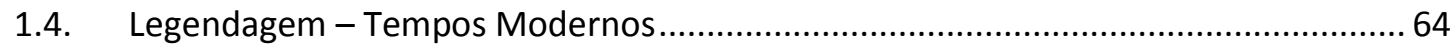

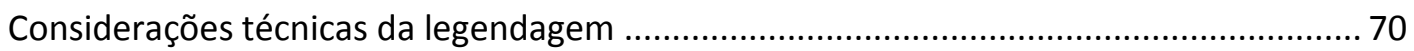

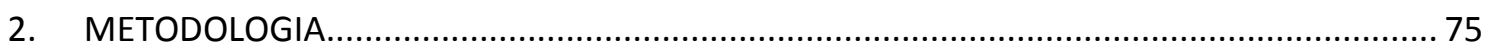

3. ANÁLISE DOS FILMES - A Última Sessão de Cinema …….................................................... 77

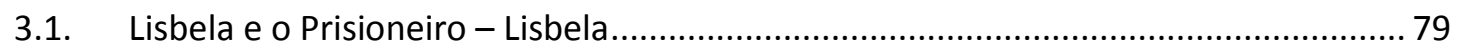

3.2. A Marvada Carne - Strong Meat............................................................................. 92

3.3. Quincas Berro D'Água - Quincas Wateryell ........................................................... 100

3.4. O Auto da Compadecida - A Dog's Will .................................................................. 113

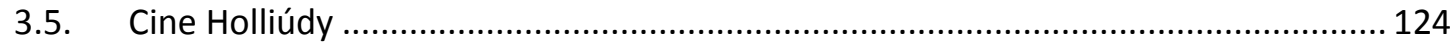

3.6. O Bem Amado - The Well Loved One ..................................................................... 135

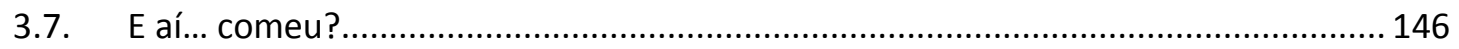

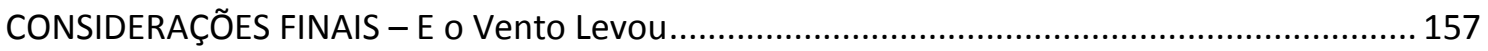

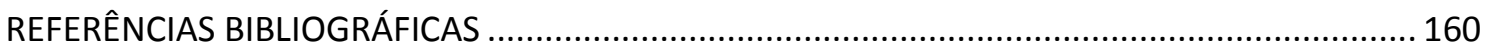

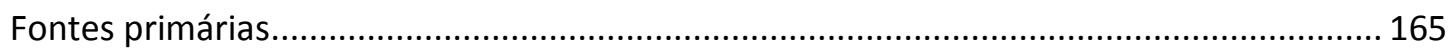

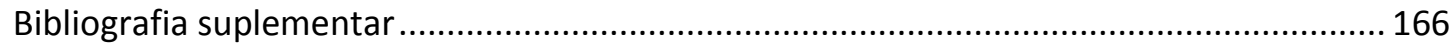




\title{
INTRODUÇÃO - Grandes Esperanças ${ }^{1}$
}

\author{
Devagar e cuidadosamente, com infinito respeito, \\ o Tradutor vai descascar as camadas \\ de palavras, sentidos, estruturas, \\ personagens, cenários, vozes e movimentos, \\ colocando-os sob a luz e inspecionando-os \\ paciente e amorosamente, \\ e começar do zero a mágica alquimista da transformação \\ - só que nesse caso o truque é ainda mais complicado - \\ de transformar ouro em ouro. ${ }^{2}$
} Thomas Rose-Masters

A tradução é definida, de forma geral e genérica, como "o processo de converter a fala ou a escrita de uma língua (a língua fonte) para outra (a língua meta)" 3 (ATTARDO, 2002, p. 173). Esta definição, ainda que talvez por demais abrangente e passando ao largo da crucial questão da significação - o terceiro elemento que se interpõe na tradicional dicotomia 'significado' e 'significante', a relação vertical que se estabelece no interior do signo linguístico - presume que a prática da tradução seja uma arte, pois envolve escolhas linguísticas subjetivas com a intenção de manter a substância/significação do enunciado. Ampliando esse espectro, a tradução de humor traz ainda maior complexidade, pois, além das escolhas linguístico-culturais relacionadas ao conteúdo em si, há também a forma, o enunciado, com a intencionalidade do efeito que o texto deseja produzir, ou seja, o riso e o divertir-se, por vezes até impondo a mudança de sentido para manter a hilaridade na outra língua, na outra cultura.

A subjetividade e a complexidade da tradução do humor encontram mais um condicionante quando se trata da tradução de humor em legendas audiovisuais. A

\footnotetext{
${ }^{1}$ Os títulos deste trabalho vêm seguidos de um título de filme, numa alusão ao que será desenvolvido no capítulo em questão. Ressalte-se que a alusão se refere ao título do filme, e não necessariamente ao seu enredo. Inseri informações sobre cada filme em nota de rodapé; tais informações foram retiradas da página da internet Adoro Cinema (www.adorocinema.com). Grandes Esperanças (Great Expectations) é uma "modernização do clássico de Charles Dickens sobre o órfão Bell, seu amor pela bela e fria Estella, criada por senhora cruel que busca vingança contra os homens por ter sido abandonada na beira do altar, $\mathrm{e}$ o misterioso benfeitor que muda o destino do rapaz". Há 3 versões do filme - de 1946, de 1988, e de 2012.

${ }^{2}$ Ao longo deste trabalho, decidi manter as citações sempre em português. No caso de textos em língua inglesa ou espanhola, o texto original será colocado em nota de rodapé. Quando não houver indicação contrária, as traduções são de minha autoria. "Slowly, carefully, with infinite respect, a Translator will peel away the layers of work, meaning, structure, character, setting, voice and movement, hold them against the light, inspect them patiently and lovingly, and begin anew the alchemist's magic of transformation - only in this case the trick is even more impossible - of turning gold into gold." 3 "The process of changing speech or writing from one language (the source language) into another (the target language)."
} 
legendagem - uma das formas de tradução audiovisual - é considerada por muitos como uma 'adaptação', visto que há uma transferência da linguagem oral para a linguagem escrita e as limitações espaço-temporais exigem o estabelecimento de prioridades na tradução. A adaptação aqui se refere tanto a um procedimento de 'equivalência situacional', como indicado por Vinay e Darbelnet (RAW, 2013, p.22), como a um processo tradutório proposto por Julie Sanders: "uma tentativa de tornar o texto 'relevante' ou facilmente compreensível para públicos e leitores por meio de processos de aproximação e atualização"4 (SANDERS, apud RAW, 2013, p. 22). Segundo Ali Hajmohammadi (2004), "boa legendagem significa decidir o que é secundário e o que é vital na informação." ${ }^{\circ}$ O humor na legendagem precisa ser construído de forma inequívoca, isto é, todas as peças precisam se encaixar com cuidado e maestria para que não haja desconcertos e a mensagem seja clara, pois só há uma chance de transmiti-la - o espaço restrito de uma legenda.

Reconstrução também se manifesta na tradução de linguagem sensível, especialmente para legendagem, pela sua evidenciação extremada, ou seja, o texto estará lá, 'grudado', queimado na imagem. O imperativo de esclarecer o que é dito esbarra nos limites éticos e (até) morais do tradutor e de sua prática tradutória. Como afirma Santaemilia (2008, p. 224), "autocensuras podem incluir todas as formas imagináveis de eliminação, distorção, atenuação, desajuste, infidelidade, e por aí vai."6 $\mathrm{O}$ ato tradutório passa a ter peso redobrado, pois se torna mais vulnerável a atenuações e/ou amplificações. Trata-se de dar todo o colorido do texto original, na medida do possível, com a paleta de cores da língua alvo.

\section{Seleção do Corpus (filmes selecionados)}

O corpus de filmes foi selecionado a partir da análise de alguns títulos de comédia da cinematografia brasileira com legendas em inglês que, além de apresentar possibilidades de análise do humor verbal, também aludem a conteúdos de caráter mais sensível, seja pela linguagem carregada no erotismo, seja por fazer referência a tabus ou a um ideário cultural muito peculiar ou restrito. De uma

\footnotetext{
4 'an attempt to make text 'relevant' or easily comprehensible to new audiences and readerships via the processes of proximation and updating."

5 "[...] good subtitling means deciding what is padding and what is vital information."

6 "Self-censorships may include all the imaginable forms of elimination, distortion, downgrading, misadjustment, infidelity, and so on."
} 
listagem de filmes, havia ainda o imperativo de haver, no mercado, cópias com legendas em inglês. Os filmes escolhidos foram: Lisbela e o Prisioneiro, O Auto da Compadecida e O Bem Amado, de Guel Arraes; Cine Holliúdy, de Halder Gomes; E aí... Comeu?, de Felipe Joffily; Quincas Berro D’Água, de Sérgio Machado; e A Marvada Carne, de André Klotzel.

Definidos os filmes, segue-se o detalhamento teórico da pesquisa e a investigação das legendas em inglês dos filmes acima mencionados, em suas manifestações humorísticas ou de linguagem sensível. Segundo Shuttleworth \& Cowie (apud SÁ, 2014, p. 8), a intenção de uma pesquisa descritiva é explicar "o fenômeno de traduzir e da tradução como ele se manifesta no mundo de nossa experiência"7. Para tal, este estudo está dividido em duas partes: uma visão teórica da tradução do humor e das instâncias em que a fala se caracteriza como peculiar ou sensível (com suas implicações e conotações), assim como das técnicas de tradução e legendagem utilizadas nas legendas em inglês dos filmes supracitados; e uma análise de instâncias de humor e linguagem sensível nesses filmes, sob a luz das teorias pesquisadas.

A divisão do presente projeto tem por objetivo: (i) definir o tipo de humor encontrado nos filmes; (ii) especificar as estratégias tradutórias das legendas com vistas a manter a estrutura essencial do humor; e (iii) examinar as instâncias nas quais a linguagem utilizada possa conter matizes de linguagem mais sensível e sua resolução na tradução. Foram selecionados trechos dos filmes com instâncias de humor, variantes regionais, linguagem tabu e toda sorte de elementos prosódicos que desafiam a tradução; neles serão observadas, descritas e analisadas as escolhas feitas pelos tradutores - que não são identificados em nenhum dos DVDs, nem ao menos a empresa responsável, uma falha bastante grave no contexto globalizado atual - e o resultado na recriação do aspecto humorístico ou cultural por meio das legendas.

\section{Justificativa}

A tradução audiovisual é uma necessidade nos dias globalizados de hoje, em que as urgências se manifestam em todas as áreas, inclusive na velocidade da comunicação.

\footnotetext{
7 “... describe the phenomena of translating and translation(s) as they manifest themselves in the world of our experience."
} 
No entanto, segundo Jorge Díaz-Cintas (DÍAZ-CINTAS; REMAEL, 2007, p. 57), seria impossível transmitir todas as informações - em especial as de relevância cultural - no espaço restrito de uma legenda, ou seja, legendas não têm notas de rodapé. Numa situação de escolha linguístico-cultural, qual seria a opção? Existiria uma alternativa que pudesse compensar uma eventual perda ou conflito na tradução? Ou a suposta perda poderia se transformar num imprevisto ganho, enriquecendo o composto multimodal do filme?

Minha motivação para esse estudo foi, em princípio, a simples curiosidade de entender o porquê de determinadas escolhas linguísticas em legendas de filmes e/ou seriados de TV. Essa curiosidade me levou a fazer diversos cursos na área e perceber que tal conflito talvez seja, em termos linguísticos e culturais, inevitável, ainda que bem-vindo, uma vez que as escolhas revelam juízos e discernimentos sincrônicos, evidenciando o momento linguístico/cultural tradutório. Esse enfoque parece manifestar certa ótica melancólica em relação à tradução, como expresso por Susana Kampff Lages, ao explicar que o tradutor vive em constante estado de melancolia, de conviver com escolhas que fatalmente eliminam outras opções. Para Ortega y Gasset (em LAGES, 2002, p.66),

\footnotetext{
o tradutor, à semelhança do falante da língua, tem que fundar sua atividade numa renúncia: para o falante, renunciar a dizer a totalidade daquilo que lhe ocorre; para o tradutor, trata-se de renunciar a traduzir tudo o que se encontra potencialmente no original, e assim conviver com uma incompletude, com uma falta que são a própria condição da linguagem e do traduzir.
}

Para ele (MARTíN, 1995, p. 246), mais do que o que se diz, a essência da linguagem se compõe de silêncios, e aí reside a miséria e o esplendor da tradução: a enorme dificuldade da tradução é que ela quer dizer num idioma exatamente o que este idioma tende a silenciar. Tendo isso em vista, o questionamento que se faz é sobre as alternativas linguísticas para minimizar ou dirimir possíveis conflitos tradutórios e avaliar o quanto se ganha com eles.

\section{Objetivos}

O presente projeto tem como propósito abordar alguns aspectos da tradução para a legendagem de instâncias humorísticas e aspectos sensíveis da linguagem, que 
envolvem tabus, preconceitos, inferências eróticas, levando em consideração tanto aspectos linguístico-culturais da tradução quanto aspectos técnicos da legendagem. Pretende também verificar ganhos e/ou conflitos linguísticos ou culturais no processo de legendagem de passagens humorísticas de filmes brasileiros com legendas em inglês, examinando ainda prismas linguísticos da tradução de linguagem sensível.

Sendo a intenção deste estudo analisar as escolhas linguísticas efetivadas nas legendas em inglês de trechos de comédias brasileiras, examinando possíveis conflitos e ganhos nas opções feitas, a fundamentação para tais escolhas e alternativas que poderiam enriquecê-las, ampliá-las ou torná-las mais comunicativas ou acessíveis para o público de língua estrangeira, estabeleceram-se as seguintes perguntas de pesquisa: (i) Como o humor foi traduzido no espaço limitado da legenda? (ii) Nesse mesmo espectro tradutório, como é mostrada a linguagem dita sensível, isto é, referente a aspectos culturais explicitados em ironia, tabus, preconceitos e afins? (iii) Há ganhos ou conflitos - tanto linguísticos quanto culturais - perceptíveis nessas ações tradutórias? (iv) Quais foram as estratégias adotadas e como foram realizadas nas legendas? (v) Quais foram as opções feitas para solucionar eventuais conflitos, caso constatados ou percebidos?

Esse estudo poderia ainda ser uma observação de nuances da tradução de humor, tanto no aspecto socializador como na perspectiva de incongruência e/ou preconceito ou tabu. O humor aparece de diversas formas, pode incluir ou excluir, e frequentemente evidencia desafios tradutórios que merecem uma análise mais aprofundada, em suas potenciais ampliações ou possíveis cicatrizes tradutórias. ${ }^{8}$

\section{Resultados Esperados}

1. Após análise de trechos de comédias brasileiras com legendas em inglês, observar as estratégias utilizadas para a tradução de instâncias humorísticas no espaço exíguo da legenda, com a intenção de determinar a existência de ganhos

\footnotetext{
${ }^{8} \mathrm{O}$ termo 'cicatrizes tradutórias' foi anotado pela pesquisadora durante uma apresentação da professora Alice Maria de Araújo Ferreira no $23^{\circ}$ Café Científico, realizado em Brasília em 04/05/2015 (acesso: https://www.youtube.com/channel/UCBvSIDrzH29cJSrJ4NuAtmw)
} 
ou conflitos linguísticos e/ou culturais, assim como examinar as estratégias tradutórias e de legendagem utilizadas.

2. Nesse mesmo escopo, refletir sobre as escolhas linguísticas e como elas carregam consigo todo um arcabouço de ideias, estereótipos, pré-conceitos e preconceitos, isto é, linguagem sensível ou culturalmente particularizada, que poderia implicar em desafios tradutórios, e evidenciar a solução de tais conflitos. 


\section{REFERENCIAL TEÓRICO - A Missão ${ }^{9}$}

O tradutor não oferece mais ou menos informação que o produtor de um texto de partida; o tradutor oferece outra informação $e$ de outra maneira.

R. Soellner

A fundamentação teórica para o desenvolvimento desse estudo é a Teoria dos Dois Scripts, ou Teoria de Script Semântico de Humor (TSSH), de Attardo (RUYTER, 2012), a Teoria Geral do Humor Verbal (TGHV), de Raskin e Attardo (ROSAS, 2003), a Teoria do Escopo de Reiss e Vermeer (ROSAS, 2003), em consonância com sua extrapolação e aprofundamento, a Teoria Funcionalista desenvolvida por Christiane Nord, composta por elementos extra e intratextuais que determinam o propósito ou função do texto, assim como o arcabouço das várias teorias e ideias que culminaram nas formulações mais alicerçadas das teorias acima. Há também pinceladas da recente Teoria Ontológico-Semântica do Humor (OSTH Ontological Semantic Theory of Humor), ainda em progresso, desenvolvida a partir das teorias acima mencionadas, por Raskin, Triezenber, Hempelmann e Taylor, que combina a tecnologia ontológico-semântica com a teoria revisada de humor. Ainda, buscar-se-á o respaldo da definição de práticas de tradução para legendas de Jorge Díaz-Cintas (DÍAZ-CINTAS; REMAEL, 2007), assim como diversos autores, brasileiros e estrangeiros, que discorrem sobre tradução de humor, tradução de ironia e linguagem sensível e tradução audiovisual em geral.

Além disso, o estudo vai buscar sustentação nos procedimentos de tradução pormenorizados por Heloisa Barbosa (2007) e nas análises linguísticas de humor de Sírio Possenti (1998; 2010). Ainda, os procedimentos técnicos dos padrões de legendagem propostos por Karamitroglou $(1998 ; 2000)$ serão detalhados, no intuito de esclarecer as diversas restrições - e também as potenciais vantagens - que a tríade imagem-som-legenda impõe ao espectador de filmes legendados.

\footnotetext{
${ }^{9}$ A Missão (The Mission) é um filme de 1986 com o seguinte enredo: no final do século XVIII, Mendoza (Robert de Niro), um mercador de escravos, fica com crise de consciência por ter matado Felipe (Aidan quinn), seu irmão, num duelo, pois Felipe se envolveu com Carlotta (Cherie Lunghi). Ela havia se apaixonado por Felipe e Mendoza não aceitou isso, pois ela tinha um relacionamento com ele. Para tentar se penitenciar, Mendoza se torna um padre e se une a Gabriel (Jeremy Irons), um jesuíta bem intencionado que luta para defender os índios, mas se depara com interesses econômicos.
} 
Em princípio, o humor é de fácil definição. Segundo Jeroen Vandaele (2002, p. 147), "humor é o que causa diversão, hilaridade, um sorriso espontâneo ou uma risada". ${ }^{10}$ Mas há vários matizes nessa resposta espontânea, que pode ser uma reação à incerteza, a surpresas, e a percepções únicas criadas por nossas mentes. Em princípio, a tradução também é de fácil entendimento; no entanto, pode ser vista como arte, metáfora, estratégia, e mais. Se já foi dito que tradutor de poesia tem que ser poeta, tradutor de humor tem que ser comediante? E em princípio, legendagem também seria de fácil compreensão, mas há particularidades que tornam a atividade bastante desafiadora. A tradução de humor para legendagem é, assim, um grande desafio linguístico e cultural.

O humor depende não só do mote em si, mas principalmente da complexa interação entre a piada, a pessoa que conta a piada, e a plateia. Para Possenti (SILVA, 2006, p. 3), deveria haver uma preocupação maior em descrever os 'gatilhos' do humor. A graça está na percepção sensorial de quem ouve a piada e, no caso do humor traduzido e legendado, a piada é, na maioria das vezes, claramente visível e perceptível, já que o produto final de um filme legendado é "polissemiótico, isto é, transmite mensagens por meio de diversos códigos"11 (CHIARO (ed.), 2012, p. 4). Dessa maneira, as reações ao humor verbal, traduzido e legendado não são meramente uma questão de distanciamento ou aproximação cultural, mas são também influenciadas pelo distanciamento ou aproximação emocional.

$\mathrm{O}$ que dizer da linguagem sensível, que pode se apresentar como e representar um tabu, um preconceito, uma piada de duplo sentido, uma alusão ao erotismo? Segundo Santaemilia (2010, p. 139), "traduzir a linguagem relativa ao sexo é, sem dúvida, uma área muito sensível, o lugar de confluência entre as interdições sociais e os limites éticos de cada tradutor". ${ }^{12}$ Poderia haver algum tipo de manipulação - consciente ou não - da tradução e elaboração linguística e retórica da linguagem do amor e do erotismo? Qual seria a medida dos cuidados tradutórios em relação à tradução de humor, amor, tabu, sexo, erotismo? Há muita controvérsia num tema tão repleto de sutilezas.

\footnotetext{
10 "Humor is what causes amusement, mirth, a spontaneous smile and laughter."

11 “...polysemiotic; that is, they transmit messages by means of diverse codes."

12 "Traducir el lenguaje relativa al sexo es, sin duda, un área muy sensible, el lugar de confluencia entre las interdicciones sociales y los límites éticos de cada traductor."
} 


\subsection{Humor... - Apertem os Cintos, o Piloto Sumiu! ${ }^{13}$}

$O$ riso provém de uma expectativa que se resolve subitamente em nada.

Kant

Dentre os vários matizes da língua, temos a linguagem do humor. A definição de humor pode parecer simples, mas o humor é , em geral, bem mais complexo; são vários os fatores que precisam se associar para tornar um enunciado humorístico, ou engraçado. Pode-se rir "com" ou rir "de", e há sempre a quebra de expectativa, "quando há incongruência entre o que é esperado e o que de fato ocorre" (ROSAS, 2002, p. 25). O humor pode ser universal, mas também, segundo Irala e Fernández (2004, p. 4), tem suas variantes, pois “é, sem dúvida, um sentimento social, distinto e peculiar em cada sociedade."14

São tantas as variantes de linguagem humorística quanto são as definições de humor, desde a dicionarizada "ação de rir ou de fazer outra pessoa rir; característica ou atributo do que é engraçado ou divertido; graça, jocosidade ou jovialidade" (http://www.lexico.pt/humor/), passando inclusive por seu significado fisiológico até a visão psicológico-filosófica de humor, que percebe o humor como uma forma de enganar nossa censura e assim provocar alívio e o riso, tendo, portanto, uma função catártica. O humor pode ser puramente verbal, visual, ou uma mistura de ambos, fazendo referências linguísticas ou culturais, sejam regionais, nacionais ou universais, desde os trocadilhos, passando pelas incongruências e à comédia pastelão.

O que determina se algo é engraçado - e causa riso - ou não? Seria a reação ou a ação criadora? Vandaele (RIETVELD, 2008, p. 20) sugere que a definição minimalista seria a melhor: o humor vem do efeito de uma ação ou enunciado. Pode ser uma piada, um trocadilho, um gracejo, uma anedota, uma paródia, um comentário sarcástico ou irônico, o que quer que produza uma reação de divertimento. "O humor necessita de e busca a cumplicidade" 15 (ROMERO, 2013, p. 46), pois nos obriga a estabelecer valores para determinar se vamos rir de alguém ou fazer com que alguém ria.

\footnotetext{
${ }^{13}$ Apertem os cintos... o piloto sumiu! (Airplane!) é uma comédia de 1980 que conta as desventuras do piloto Ted Striker (Robert Hays), ex-combatente de guerra, é forçado a assumir os controles de um avião quando a tripulação sucumbe à comida contaminada. Elaine (Julie Hagerty), sua namorada, tem de ser aeromoça e copiloto. Juntos, eles vão tentar salvar os passageiros e terminar o voo com sucesso, mas há um problema: ele é neurótico.

14 "El humor es, sin duda, un sentimiento social, distinto y peculiar en cada sociedad."

${ }^{15}$ El humor necesita y busca la complicidad.
} 
Rir de alguém é assumir os valores de quem propõe a piada e rechaçar os valores daquele de quem rimos. Este tipo de humor busca, portanto, a estigmatização do outro, sua segregação: rir de alguém é separá-lo do conjunto. O riso baseado na ridicularização forma um cinturão de isolamento em relação ao objeto do riso. ${ }^{16}$ (ROMERO, 2013, p. 46)

As teorias de humor podem ser classificadas em três grandes grupos não excludentes, segundo uma abordagem multidisciplinar mais abrangente (http://www.iep.utm.edu/humor/\#H1): teoria da superioridade, teoria da incongruência e teoria do alívio. A teoria da superioridade parte do pressuposto que o humor vem de um sentimento de superioridade em relação ao outro ou ao objeto de nosso riso, uma sensação de "glória repentina" ${ }^{17}$, ou o prazer diante do infortúnio alheio. Foi criticada por não contemplar situações simples como trocadilhos e a possibilidade de rir de si mesmo. A teoria da incongruência ou incoerência preconiza que o riso vem da incoerência entre a expectativa e a realidade, isto é, a associação de ideias opostas ou da impossibilidade lógica de algo que temos como natural. Essa teoria é a mais ampla em relação ao gatilho do humor. E a teoria do alívio é uma forma de remover a tensão, de produzir uma catarse, e tem fundamento na psicologia. Há ainda a teoria da brincadeira (play theories), que classifica o humor como uma forma de brincadeira semelhante à dos animais, isto é, instintiva e que resulta em divertimento.

O humor se manifesta, fisicamente, no riso. Para Bergson (SILVA, 2006, p. 115), o riso se relaciona à inteligência, e acontece mais espontaneamente em contato com outras inteligências, isto é, é mais fácil e eficaz na coletividade, além de ser um indicador das ações de sociabilidade. "O riso deve ser alguma coisa desse tipo, uma espécie de gesto social" (BERGSON, apud SILVA, 2006, p.26). Assim, "o riso decorrerá, ou não, da forma pela qual o ouvinte fará sua interpretação do discurso e do que essa interpretação significa para ele" (SILVA, 2006, p.90).

Por seu caráter socializante, o discurso do humor é relevante por diversas razões; piadas são como um 'sintoma' social, isto é, podem revelar manifestações culturais e ideológicas, assim como valores e crenças arraigados. Piadas são também material de pesquisa de representações de estereótipos (portugueses burros, baianos preguiçosos, etc.) e ainda evidenciam um discurso "proibido, subterrâneo, não

\footnotetext{
16 "Reírse de alguien es asumir los valores del que propone el chiste y rechazar los valores de aquel de quien nos reímos. Este tipo de humor busca, por tanto, la estigmatización del otro, su segregación: reírse de alguien es separarlo del conjunto. La risa basada en la ridiculización forma un cinturón de aislamiento respecto al objeto de la risa."

17 "Sudden glory", termo cunhado por Thomas Hobbes.
} 
oficial, que não se manifestaria, talvez, através de outras formas de coletas de dados" (POSSENTI, 1998, p. 26). Ainda, sob o ponto de vista linguístico, as piadas são interessantes como dados textuais que mostram, em sua análise e interpretação, um "domínio da língua de alguma forma complexo" (POSSENTI, 1998, p. 28).

Em relação à recepção do humor, Possenti (1998) afirma que há polêmica e contradições na tentativa de encontrar sentido na tríade autor-texto-leitor. Na verdade, nenhum deles é suficientemente autônomo para controlar o sentido do texto; os três são interdependentes e complementares, repletos de 'semias', pois "há uma coautoria e interação no processo de construção de sentido". Isso vale, naturalmente, para a tradução também. A fragmentação dessa tríade custaria o resultado final do riso ou divertimento. Possenti (ROSAS, 2002, p. 27) acrescenta que não existe uma linguística do humor, pois não há uma abordagem explícita dos ingredientes humorísticos necessários para tornar um texto humorístico. Tampouco há uma linguística "que explicite ou organize os ingredientes linguísticos que são acionados para que o humor se produza" (ROSAS, 2002, p. 27), ou que verifique se os mecanismos para a geração de humor são exclusivos.

Embora não exista uma linguística específica do humor - o que surpreende porque o humor é abundante, provavelmente existente em todas as culturas - há teorias que buscam explicar a realização e a recepção do humor verbal. Elas enfocam a "importância da enunciação, ou seja, o modo de formulação do elemento verbal" (ROSAS, 2002, p. 26). Algumas delas serão explicitadas a seguir, levando em consideração que:

\footnotetext{
“a maioria das teorias de humor já propostas são, na verdade, teorias mistas, e muitos pesquisadores contemporâneos acreditam que o humor em sua totalidade, é um fenômeno muito grande e multiforme para ser incorporado a uma única teoria."18 (KRIKMANN, 2006, p.28)
}

\footnotetext{
18 "Most of the humour theories ever proposed are actually mixed theories, and many contemporary researchers believe that humour in its totality is too huge and multiform a phenomenon to be incorporated into a single integrated theory."
} 


\subsubsection{Teoria dos Dois Scripts / Teoria Geral do Humor Verbal / Teoria Ontológico-Semântica do Humor}

A Teoria dos Dois Scripts (ou Teoria do Script Semântico de Humor TSSH), concebida por Victor Raskin, foi aplicada primeiramente apenas à explicação de piadas. Anteriormente, Arthur Koestler já havia determinado que o "humor envolve um paradoxo, pois o riso é uma reação fisiológica a uma variedade de diferentes e complexos estímulos intelectuais e emocionais ${ }^{19}$ " (KRIKMANN, 2006, p.29) e, ainda que sua teoria não tenha recebido muita atenção por não ser especificamente voltada para a comicidade, a ideia de criatividade e bissociação de construtos abriu uma linha de pensamento para o estudo particularizado do humor. A Teoria Geral do Humor Verbal, de Raskin e Attardo, revê e amplia a Teoria dos Dois Scripts, incluindo, além da semântica, a linguística textual, a teoria da narratividade e a pragmática, explicitando que a "existência de um desvio que quebra as expectativas de leitura é o que confere ao texto o seu caráter humorístico" (ROSAS, 2003, p.144). Por fim, uma pincelada da Teoria Ontológico-Semântica do Humor, que prevê uma análise algorítmica/matemática da oposição de scripts, e caminha para a subversão, revisão e expansão dos enunciados das teorias anteriores.

Particularizando a teoria da incongruência - e de certa forma, todas as outras, já que elas não são excludentes - e adentrando um âmbito mais linguístico, o humor verbal busca teorias que possam descrever seu labiríntico conjunto de possibilidades. As teorias que mais respondem a essa demanda são a Teoria dos Dois Scripts, desenvolvida por Raskin e a Teoria Geral do Humor Verbal, de Raskin \& Attardo, explicitadas a seguir, precedidas pela 'arte da criação' de Arthur Koestler e sucedidas pela Teoria Ontológico-Semântica do Humor.

Ao que tudo indica, a primeira referência formal a uma teoria do humor foi a visão de Arthur Koestler em seu tratado O Ato de Criação (1964). A tese central da teoria - que envolve não só humor, mas também arte e ciência - estabelece que os processos criadores partem de uma 'bissociação', que seria a conexão de níveis de experiência ou sistemas de referência. No pensamento rotineiro, fazem-se associações; no pensamento criativo, bissociações. O ato criador origina conexões entre dimensões de experiências antes não relacionadas. No caso do humor, isso

\footnotetext{
19 “...humour involves a paradox, because laughter is a universal physiological reaction to a very great variety of different complex intellectual and emotional stimuli."
} 
significa "uma colisão ou oscilação cômica entre duas estruturas de referência mundos discursivos - códigos - contextos associativos"20 (KRIKMANN, 2006, p.28). A bissociação súbita entre duas matrizes incompatíveis causa um salto abrupto entre tais estruturas, e essa tensão encontra solução no riso. Essa primeira referência ao humor como estrutura singular passível de estudo e teorização foi um impulso para o desenvolvimento de teorias que ressaltavam também a regulação social e a não uniformidade do riso.

A Teoria dos Dois Scripts - ou Teoria do Script Semântico - de Victor Raskin, carrega a hipótese de que um texto - pois se refere exclusivamente ao humor verbal - pode ser caracterizado como humorístico se atender a duas condições básicas: a) o texto é compatível, parcial ou totalmente, com dois scripts diferentes; e b) os dois scripts com os quais o texto é compatível são opostos.

Um script é um trecho de informação sobre algo (em sentido mais amplo). É uma estrutura cognitiva internalizada pelo falante que proporciona ao falante informações sobre como as coisas são feitas, organizadas, etc. ${ }^{21}$ (ATTARDO, 1994, apud RUYTER, 2012, p.17).

Tal teoria - precedida por uma descrição exaustiva da essência do humor, dos elementos constitutivos do ato de humor, de conceitos básicos da pesquisa e dos tipos de riso - é uma "tentativa de explicar a competência humorística dos falantes nativos de uma língua, segundo a qual um texto humorístico tem necessariamente dois scripts" (FRANCO e BRANDÃO, 1998, apud ROSAS, 2002, p. 30). De certa forma, a competência humorística se assemelharia à competência linguística de Chomsky; o falante da língua sabe distinguir o que é gramatical e o que não é, e também o que é engraçado e o que não é. Já a noção de script vem da psicologia: como visto acima, um script é uma "estrutura cognitiva internalizada pelo falante que lhe permite saber como o mundo se organiza e funciona" (ROSAS, 2002, p. 31).

A hipótese da TSSH preconiza que um texto de apenas um script pode ser lido ou entendido de maneiras diferentes. Por exemplo, se alguém diz: Vou dizer algo profundo: núcleo da terra. Há dois scripts diferentes evocados pela palavra 'profundo' - a primeira condição foi então satisfeita. Mas isso não necessariamente

\footnotetext{
20 “....comic collision of or oscillation between two frames of reference - worlds of discourse - codes associative contexts."

21 "A script is an organized chunk of information about something (in the broadest sense). It is a cognitive structure internalized by the speaker which provides the speaker with information on how things are done, organized, etc."
} 
cria um texto humorístico. A segunda condição precisa ser atendida também, isto é, é preciso haver uma oposição entre os scripts, que se realizam entre o que é real $\mathrm{x}$ irreal, normal x anormal, possível x impossível. No caso da piada acima, pode-se dizer que a expectativa de algo 'profundo' não se realizou, não foi o que se esperaria como 'normal'. Apesar de o núcleo da terra ser profundo, essa profundidade se refere apenas a um aspecto físico/geográfico, ao passo que o esperado - a expectativa - seria de algo profundo no sentido filosófico.

A TSSH de Raskin também segue máximas de comunicação; são elas: a máxima da quantidade: ou quanto menos informação, melhor; a máxima da qualidade: ou ater-se ao universo da piada; a máxima da relação: ou apoiar-se apenas no que é relevante para a piada; e a máxima da maneira: ou como ela é contada. Se as condições para a realização da piada e as máximas para que ela seja comunicada eficientemente forem seguidas, a aplicabilidade da teoria é verdadeiramente transcultural. A ressalva feita à TSSH seria o fato dela estar restrita a piadas, revelando dificuldades de aplicação a outros tipos de textos humorísticos ou instâncias humorísticas.

Em suma, o humor frequentemente se apresenta em duas grandes categorias: a incongruência e o absurdo (nonsense). A resolução de tiradas humorísticas busca 'resolver' essa incongruência ou absurdo. Uma teoria linguística de humor - a Teoria do Script Semântico do Humor (TSSH) - foi desenvolvida por Raskin em 1985 e foi mais tarde (1991) revisada e ampliada com a colaboração de Attardo, e renomeada Teoria Geral do Humor Verbal (TGHV). Como visto, segundo essa primeira teoria, o humor é produto de um mecanismo básico chamado Oposição de Scripts, que se enquadra em três classes: "verdadeiro vs. não-verdadeiro, normal vs. anormal, possível vs. impossível. As três classes são exemplos de uma oposição básica entre situações reais e irreais nos textos" (SILVA, 2006, p. 18). Isso significa que o humor deriva da incongruência entre dois scripts diferentes que são compatíveis e se sobrepõem no mesmo texto.

A alteração e extrapolação da TSSH - que se restringia ao estudo de piadas responde agora por qualquer tipo de humor verbal e aponta que tal oposição de scripts vem acompanhada de "ferramentas do conhecimento" que Raskin e Attardo chamaram de 'knowledge resources', a saber: a língua, ou seja, o tipo de linguagem usada para contar a piada ou outra forma de expressão humorística, ou a 
verbalização do pensamento; a estratégia de narração, que pode ser um diálogo, uma adivinha, uma charada; o alvo, que diz respeito ao sujeito ou aos sujeitos ridicularizados na piada, se for o caso; a situação, ou o contexto em que a piada está envolvida e que vai dar o 'suporte logístico' da piada; e o mecanismo lógico, que diz respeito à forma em que os scripts em oposição na piada serão conduzidos, seja justaposição direta, falsa analogia, ou outro mecanismo que sobreponha os scripts incongruentes. Em relação aos mecanismos lógicos, Attardo os considerava seus enfants terribles, pois são ao mesmo tempo ferramenta do conhecimento e uma função da oposição de scripts, que motiva a sobreposição. O mecanismo lógico é um elemento problemático porque "lógico não se refere à lógica dedutiva ou à lógica formal, mas deve ser entendido de uma forma mais comum, como 'pensamento e ação racional', ou até 'possibilidade ontológica”,22 (KRIKMANN, 2006, p. 37).

Para compreender essa oposição e a utilização das "ferramentas" para a recepção do humor, vejamos um exemplo de uma piada traduzida do inglês. $A$ couple of cannibals was going to cross the street. The husband offers to give the wife a hand. She says: thanks, I've had lunch already. E sua tradução: Um casal de canibais ia atravessar a rua. O marido oferece o braço à esposa. Ela diz: obrigada, já almocei. A língua, ou formulação verbal, é direta, sem meandros, com frases curtas e pontuais, em um misto de narração e diálogo como estratégia narrativa. $\mathrm{O}$ alvo - ainda que insensato - são os canibais, sujeitos da piada. A situação é uma situação real e corriqueira - atravessar a rua - e o mecanismo lógico é a oposição entre a situação real e a referência feita ao canibalismo. Se não houvesse a menção ao canibalismo, a piada perderia quase toda a graça. Também perderia a graça se a formulação verbal fosse mais formal ou extremamente literal (como 'o marido se oferece para dar a ela uma mão’).

A visão de humor verbal se coloca como dois scripts sobrepostos e opostos, mas percebidos pelo recipiente como um script único, cuja ambiguidade linguística gera o riso. No entanto, ele depende não só da piada, mas da complexa interação entre contador e receptor da piada. Por ser o humor um ato social de mão dupla, ele vai além das várias teorias compiladas e combinadas e poderia enfocar não apenas as

\footnotetext{
22 "Here, logical does not stand for deductive logic or strict formal logicality but rather should be understood in some looser quotidian sense 'rational thinking and acting' or even 'ontological possibility'.
} 
oposições de scripts e os mecanismos lógicos, mas principalmente a 'lógica social', como nas palavras de Tony Veale (2004, apud KRIKMANN, 2006, p. 54):

[...] O que é necessário não é um mecanismo lógico como tal, ou uma lógica de oposições, mas uma lógica social que admita uma teoria que baseie a interpretação nas questões e preconceitos específicos do ouvinte como agente social. $^{23}$

Seguindo essa linha de pensamento, e levando em consideração que novas teorias surgem da revisão e/ou da subversão das predecessoras, a TSSH e a TGHV foram reconsideradas e a vem paulatinamente dando lugar à Teoria OntológicoSemântica do Humor (TOSH), que tem sua base na Tecnologia Ontológico-Semântica, que oferece procedimentos para descobrir a oposição principal numa piada, um algoritmo que, segundo os autores, "será um passo inicial, esperamos, em direção à compreensão de como piadas são montadas e quais são suas lógicas internas/falsas"24 (RASKIN, HEMPELANN e TAYLOR, 2009, p. 286).

A Teoria Ontológico-Semântica do Humor é um passo a frente nas teorias de humor verbal porque alia conhecimentos linguísticos a conhecimentos do mundo e do ser para se chegar aos passos necessários à compreensão da piada, a saber:

a percepção do absurdo da premissa inicial, sua aparente validação por incapacidade de ser questionada ou revidada, e uma pseudo-resolução com um componente de aparente 'plausibilidade', todos eles detectáveis e acessíveis ao processamento Ontológico-Semântico do sentido do texto. ${ }^{25}$ (RASKIN, HEMPELMANN e TAYLOR, 2009, p. 307)

As teorias que tentam explicar o humor e o que faz rir são várias, multifacetadas e não exclusivas, assim como os gatilhos do humor.

No que diz respeito ao humor, sabe-se que não é fácil dar uma definição que possa conter as numerosas nuances e facetas do seu campo semântico, tratando-se de uma categoria profundamente ligada às estruturas pragmáticas e socioculturais da sociedade de que é expressão e à (variante de) língua em que se realiza (DE ROSA, 2011, p. 1).

\footnotetext{
${ }^{23}[\ldots]$ What is needed is not a logical mechanism as such, or a logic of oppositions, but a social logic that allows a theory to ground the interpretation in the specific concerns and prejudices of the listener as a social agent.

24 "This will be an initial step, we hope, towards understanding how jokes are put together and what exactly their internal/false logics are."

25 "the realization of the absurdity of the initial premise, its apparent validation by failure to question or reject, and a pseudo-resolution with a piece of apparent 'plausibility', are all detectable by, and accessible to, the OST processing of the meaning of the text."
} 
Levando-se em consideração as tantas teorias relativas ao humor verbal e os motivos que levam ao riso, tantas serão também as teorias que esmiuçam a tradução do humor. Assim como todas as teorias, elas se complementam ao subverter e/ou acrescentar percepção e lucidez à(s) anterior(es). Segundo Vandaele (2002, apud DE ROSA 2011, p. 3),

A escassez de trabalhos sérios sobre a tradução de humor nos estudos de tradução sugere que a tradução de humor é qualitativamente diferente de 'outros tipos' de tradução e, consequentemente, não se pode escrever sobre tradução de humor da mesma forma que se escreve sobre outros tipos de tradução. $^{26}$

\subsubsection{Teoria do Escopo / Teoria Funcionalista}

Ainda no âmbito das teorias que definem o humor, e já adentrando o universo da tradução, encontramos teorias abrangentes no que diz respeito à linguagem e particularizadas no tocante à tradução. Assim sendo, as teorias a seguir, a Teoria do Escopo e a Teoria Funcionalista, respondem à tradução de humor e linguagem sensível ao abordar sua função no texto.

A Teoria do Escopo, de Katharina Reiss e Hans Vermeer, afirma que "o mais importante na tradução é sua finalidade e por isso toda ação tradutória deve se adequar para atingir tal objetivo.” (ROSAS, 2003, p. 45). Segundo Reiss e Vermeer (2013), "uma ação tenciona alcançar um objetivo e assim alterar o atual estado das

coisas." ${ }^{27}$ O que interessa e importa é a função da língua no texto. É, portanto, uma abordagem funcionalista e pragmática da tradução, referida pelos autores como translação ou ação translativa, pressupondo que:

Toda ação visa (de forma mais ou menos consciente) a um determinado
objetivo e se realiza de modo que tal objetivo possa ser alcançado da melhor
forma possível na situação correspondente. [...] A produção de um texto é
uma ação que também visa a um objetivo: que o texto 'funcione' da melhor
forma possível na situação e nas condições previstas. (REISS e VERMEER,
apud ROSAS, 2003, p. 145)

Assim, trata-se de uma teoria de ação complexa, pois não se trata de como agir, mas de como - e se - continuar a ação. Além da decisão de agir, é necessário

\footnotetext{
${ }^{26}$ The dearth of serious work on humour translation in the translation studies suggests that humor translation is qualitatively different from 'other types' of translation and, consequently, one cannot write about humour translation in the same way one writes about other types of translation.

27 "An action aims to achieve a goal and thus to alter the current state of affairs."
} 
definir a estratégia de ação, sabendo que o "princípio dominante de toda translação é sua finalidade" (ROSAS, 2003, p. 145). Em suma, em tradução, o fim justificaria os meios. As finalidades de cada ação translativa dependem do contexto e da situação, assim como das relações existentes entre os interlocutores. É o "para quê" da tradução: segundo os autores, a regra do escopo é que "pode-se definir o escopo como uma variável dependente dos receptores" (ROSAS, 2002, p. 47).

Há três fases distintas nesse processo: determinação do escopo, atribuição de novos valores a esse escopo e a realização do escopo. Na fase da determinação do escopo, define-se quem são os receptores da translação, para saber qual a função da ação; na fase de atribuição de novos valores, decidem-se as possíveis alterações que ocorrerão no ato tradutório, seja prévia ou posteriormente; e na última fase, de realização do escopo, tomam-se as decisões tradutórias seguindo os critérios estabelecidos nas etapas anteriores.

É necessário um conhecimento da cultura destinatária, já que a translação implica uma transferência cultural e linguística, ou seja: "as culturas e línguas são 'indivíduos', razão pela qual os textos, como estruturas formadas por partes de estruturas culturais e linguísticas, são também “indivíduos"” (ROSAS, 2002, p.49). Rosas explicita que:

é evidente que, na realização de uma transferência para uma estrutura diferente, os valores dos elementos transferidos devem mudar necessariamente, já que estes serão introduzidos em um novo contexto de inter-relações, o que pressupõe a impossibilidade de ressurgimento do mesmo conjunto de implicações do texto de partida. Daí decorre o fato de a tradução ser uma operação sempre transvalorativa: diferentes valores são inevitavelmente alocados no texto traduzido. (ROSAS, 2002, p. 49)

A base teórica da teoria do Escopo são três premissas: uma ação translacional é uma função de seu escopo; uma ação translacional é uma oferta de informação produzida numa cultura e língua alvo sobre uma oferta de informação produzida numa cultura e língua fonte; e a oferta de informação alvo é representada como uma transferência que simula a oferta de informação fonte. Sendo assim, a ação translacional é regida por seu propósito e é uma forma específica de interação, que precisa ser coerente em si e em relação ao texto fonte.

Também a Teoria Funcionalista desenvolvida por Nord sugere que a tradução é uma forma de interação que tem um propósito amplamente comunicativo. Tal 
propósito é alcançado por meio de um modelo que usa as três funções da linguagem descritas por Bühler (NORD, 1997, p. 48) - referencial, expressiva, e apelativa acrescida da função fática, que seria o foco em um canal aberto entre emissor e receptor. O propósito da tradução determina a escolha pelo método e estratégia; é o princípio da funcionalidade.

As abordagens funcionais da tradução são anteriores ao século XX, pois há muito se observa que há situações em que são necessários ajustes para alcançar o público alvo. São Jerônimo e Lutero (NORD, 2014, p. 4) acreditavam que havia instâncias em que o tradutor deveria reproduzir o texto "ao pé da letra" e outras passagens em que seria mais importante mostrar o sentido ou ajustar o texto ao público alvo. Nida aponta numa direção semelhante, com seus conceitos de equivalência formal e dinâmica ${ }^{28}$, o que Nida chamou de abordagem sociolinguística, pois analisa a validade de cada tradução de acordo com a resposta do receptor, obviamente levando em conta as diferenças culturais e diversidades nos sistemas de valores, suposições e antecedentes históricos.

A partir do trabalho de Nida, enaltecido por Gentzler como "a base sobre a qual uma nova área de investigação no século vinte - a 'ciência da tradução - foi fundada" ${ }^{29}$ (NORD, 2014, p. 6), a própria definição de tradução foi revista e ampliada, e a linguística passou a desfrutar de um protagonismo inédito - nos anos 1950 e 1960. Segundo Oettinger,

Tradução pode ser definida como o processo de transformar signos e representações em outros signos e representações. Se os originais têm alguma significância, geralmente é necessário que as imagens também tenham a mesma significância, ou, mais realisticamente, a maior significância possível. Manter a significância invariável é o problema central na tradução entre línguas naturais. ${ }^{30}$ (NORD, 2014, p. 6)

Ao mesmo tempo em que as teorias funcionalistas da tradução se desenvolviam, nos anos 1970, também tomava forma mais definida a concepção

\footnotetext{
28 “A tradução de equivalência dinâmica visa a completa naturalidade de expressão, e tenta relacionar o receptor a modos de comportamento relevantes dentro do contexto de sua própria cultura; não insiste que ele compreenda os padrões culturais do contexto da língua fonte para compreender a mensagem." (NORD, 2014, p. 5)

29 "the basis upon which a new field of investigation in the twentieth century - the 'science of translation' - was founded."

30 "Translating may be defined as the process of transforming signs or representations into other signs and representations. If the originals have some significance, we generally require that their images also have the same significance, or, more realistically, as nearly the same significance as we can get. Keeping significance invariant is the central problem in translating between natural languages."
} 
estruturalista de universais linguísticos, que impulsionava a ilusão de que a língua e, portanto, a tradução, uma vez que também consiste em uma operação linguística poderiam ser objeto de 'investigação científica'. Isso significaria que a tradução que anteriormente era vista como uma arte ou ofício - agora seria uma ciência dentro da linguística aplicada. Uma definição de Catford, de 1965, menciona a "substituição de material textual em uma língua (LF) por material equivalente em outra língua (LA)"31 (NORD, 2014, p. 6/7).

As abordagens de então viam a tradução como uma operação de mudança de códigos, na qual o conteúdo, a forma, o estilo e a função da língua fonte deveriam ser preservados. Por exemplo, Justa Holz-Mänttärdi apresentou, em 1981, uma teoria e metodologia do ato translacional, em que a ênfase estaria nos 'transmissores de mensagens ${ }^{32}$, tornando a tradução uma ação mais complexa, para alcançar um propósito específico. Segundo ela,

\begin{abstract}
A ação translacional é o processo de produção de um transmissor de mensagem de um determinado tipo, concebido para ser empregado em sistemas de ação superordenadas de forma a coordenar a cooperação de ação e comunicativa. ${ }^{33}$ (NORD, 2014, p. 13)
\end{abstract}

Diferentemente das teorias de cunho linguístico, os funcionalistas, como Reiss, Vermeer e Nord, buscavam os aspectos mais pragmáticos e culturais da tradução, analisando as perspectivas inter e extra textuais da ação comunicativa. Tal abordagem ajudaria a identificar os elementos relevantes tanto no texto fonte como no futuro texto alvo. No entanto, teóricos dessa abordagem forçosamente se viam em situações tradutórias em que a tradução não literal respondia melhor às necessidades de compreensibilidade. Fez-se mister uma nova teoria - e prática - que pudesse atender essas demandas, sem contudo eliminar todo o arcabouço de conhecimentos e práticas já testados e criticados. As teorias funcionalistas da tradução revisitaram os princípios de equivalência e destrincharam a relação entre textos fonte e alvo.

Segundo as teorias funcionalistas da tradução, toda tradução é uma ação. A tradução é uma forma de interação translacional, intencional, interpessoal, que

\footnotetext{
31 "the replacement of textual material in one language (SL) by equivalent material in another language (TL).

${ }^{32}$ Segundo a autora, material textual combinado a outros meios, como quadros, sons e movimentos corporais.

33 "Translational action is the process of producing a message transmitter of a certain kind, designed to be employed in superordinate action systems in order to coordinate actional and communicative cooperation."
} 
possibilita criar uma ligação entre culturas. A tradução é também uma ação comunicativa, intercultural e processual, pois ocorre em situações concretas que envolvem membros de culturas diferentes. A língua é uma parte intrínseca da cultura, principalmente se ela for definida como a "totalidade do conhecimento, da proficiência e da percepção" 34 (SNELL-HORNBY, apud NORD, 2014, p. 23). Essa visão foi esmiuçada por Ward H. Goodenough (NORD, 2014, p. 23) e serviu como ponto de partida para as abordagens funcionalistas da tradução:

\begin{abstract}
Em meu ponto de vista, a cultura consiste de tudo o que alguém sabe ou acredita, de modo a funcionar de maneira aceitável a seus membros, e assim em qualquer papel que eles aceitem para si. A cultura, no sentido do que as pessoas aprendem além de sua herança biológica, deve consistir do produto final do aprendizado: conhecimento, no senso mais geral, ainda que relativo, do termo. Com essa definição, pode-se notar que a cultura não é um fenômeno material. Não consiste de coisas, pessoas, comportamentos ou emoções. É mais uma organização dessas coisas. São as formas das coisas que as pessoas têm em mente, seus modelos de perceber, relacionar e até de interpretar tais coisas. $^{35}$
\end{abstract}

Os primeiros teóricos a abordar de forma efetiva a ação tradutória como uma relação entre texto fonte e texto alvo de forma funcional foram Katharina Reiss e Hans J. Vermeer. Eles afirmavam que a tradução era uma ação humana e, como tal, obedecia a um sistema de ações intencionais e elaboradas. Assim também seria a tradução, vista como "uma forma de ação translacional baseada num texto fonte, que pode consistir de elementos verbais e/ou não verbais (ilustrações, projetos, tabelas, etc.) ${ }^{, 36}$ (NORD, 2014, p. 11).

\begin{abstract}
Qualquer forma de ação translacional, incluindo aí a própria tradução, pode ser entendida como uma ação, como o próprio nome diz. Toda ação tem um objetivo, um propósito. [...] A palavra skopos, então, é um termo técnico para o objetivo ou propósito da tradução. [...] E mais: uma ação leva a um resultado, uma nova situação ou evento, e possivelmente a um 'novo' objeto. $^{37}$ (NORD, 2014, p. 12)
\end{abstract}

\footnotetext{
34 "... a totality of knowledge, proficiency and perception."

35 “As I see it, a society's culture consists of whatever it is one has to know or believe in order to operate in a manner acceptable to its members, and do so in any role that they accept for any one of themselves. Culture, being what people have to learn as distinct from their biological heritage, must consist of the end product of learning: knowledge, in a most general, if relative, sense of the term. By this definition, we should note that culture is not a material phenomenon; it does not consist of things, people, behavior, or emotions. It is rather an organization of these things. It is the forms of things that people have in mind, their models for perceiving, relating, and otherwise interpreting them."

36 "a form of translational action based on a source text, which may consist of verbal and/or non-verbal elements (illustrations, plans, tables, etc.)"

37 "Any form of translational action, including therefore translation itself, may be conceived as an action, as the name implies. Any action has an aim, a purpose. [...] The word skopos, then, is a technical term for
} 
A teoria do Escopo, então, é uma teoria de ação proposital. O propósito consiste em deslocar a ideia de tradução de um enfoque unicamente linguístico para uma ação intencionalmente cultural, levando em conta as necessidades comunicativas do receptor da mensagem. Por ser uma ação proposital, além do escopo, tem palavras-chave para seu funcionamento. Finalidade (aim), ou o resultado final pretendido com uma ação; propósito (purpose), que é um estágio para se alcançar a finalidade; função (function), o que o texto significa ou pretende significar para o recipiente; e intenção (intention), o plano de ação ou função da ação.

O funcionalismo "contempla a tradução como uma comunicação intercultural, na qual texto de partida e o texto de chegada pertencem a sistemas culturais distintos" (LEAL, 2006, p. 2). Para a teoria funcionalista, um texto "é um ato comunicativo que só se completará no momento da recepção” (id., 2006, p. 2), ou seja, seu escopo só se realiza se o texto encontrar reflexo. Para tal, ele tem funções específicas a desempenhar, que não são excludentes. A função de uma tradução pode ser analisada sob uma perspectiva dupla: foco na relação entre o texto alvo e seu público receptor, ou foco na relação entre o texto alvo e o texto fonte. Segundo Nord (2014, p. 46),

Por um lado, uma tradução é um texto que pretende funcionar para um grupo de receptores-alvo e, como tal, pode ter qualquer função comunicativa. Por outro, uma tradução é um tipo de representação de uma cultura-alvo ou substituta de um texto da cultura-fonte. Como tal, ela pode desempenhar funções diferentes em relação à fonte. ${ }^{38}$

Essas funções explicitadas por Nord têm objetos e referências diversas. A função referencial analisa a natureza do objeto ou referente envolvido; é frequentemente apresentada por meio do valor denotativo do item lexical presente no texto, podendo ou não ser familiar aos recipientes. A função expressiva (também chamada emocional) se refere à atitude do emissor em relação aos objetos e fenômenos do mundo; as sub-funções podem ser: emotiva, avaliativa, ou irônica, tendo essas também desdobramentos. Essa função é claramente voltada para o

the aim or purpose of a translation. [...] Further: an action leads to a result, a new situation or event, and possibly to a "new' object."

38 "On the one hand, a translation is a text which is intended to function for the target receivers and, as such, may be intended for any communicative function. On the other, a translation is a kind of targetculture representation or substitute for a source-culture text. As such, it may carry out quite different functions with regard to the source." 
emissor da mensagem. A função apelativa, como o nome diz, apela para a sensibilidade ou disposição do receptor da mensagem. Similar à função conativa de Jakobson, a função apelativa tenta induzir o receptor a responder de uma determinada maneira. Essa função é voltada para o receptor da mensagem. Por fim, a função fática - acrescentada por Nord à Teoria do Escopo, e também presente no esquema de Jakobson - seria a ligação entre emissor e receptor; ela "objetiva estabelecer, manter ou finalizar o contato entre o emissor e o receptor" ${ }^{39}$ (NORD, 2014, p. 44). Faz uso de meios linguísticos, não linguísticos e paralinguísticos para definir o quê e como se passa a comunicação entre emissor e receptor, se a relação será formal ou informal, simétrica ou assimétrica, ou seja, a forma do contato.

A função referencial é "principalmente expressa por meio do valor denotativo dos itens lexicais presentes no texto" ${ }^{40}$ (NORD, 2014, p. 40/41); ela se refere a objetos em universos reais ou fictícios, e pode ser um problema para a tradução se fonte e alvo não compartilharem do mesmo conhecimento cultural prévio. Por exemplo, uma referência às 'águas turvas do Rio Negro' ${ }^{41}$ poderia se perder na tradução, caso o receptor não tenha familiaridade com a hidrografia brasileira. A função expressiva vai além do aspecto estético dos textos, para demonstrar a atitude do emissor em relação aos objetos e fenômenos do mundo. A tradução dos 'olhos de ressaca de Capitu' (Dom Casmurro, Machado de Assis, publicado em 1899) poderia expressar algo positivo ou negativo, que foi traduzido por Helen Caldwell (1953) por 'eyes like the tide', pois 'hangover eyes' poderia soar um pouco ofensivo. ${ }^{42} \mathrm{~A}$ função apelativa não se realiza se o receptor não cooperar, pois ocorre em exemplos, alusões, comparações e metáforas, como comparar a dificuldade de aprender uma língua oriental - o Mandarim, por exemplo - com a dificuldade de 'assobiar e chupar cana'. Por fim, a função fática determina que, mais importante do que o quê se fala ou como se fala, é o contato entre emissor e receptor. Os textos costumam ser multifuncionais, isto é, possuem marcadores de verbais e não verbais de duas ou mais funções.

\footnotetext{
39 “... aims at establishing, maintaining or ending contact between sender and receiver."

40 "...mainly expressed through the denotative value of the lexical items present in the text."

${ }^{41}$ Ainda mais porque as águas do Rio Negro são transparentes em comparação com as águas barrentas e turvas do Rio Solimões, por exemplo.

${ }^{42}$ Aqui também há o problema do duplo sentido (ressaca = efeito da bebedeira / ressaca = o mar revolto), o que não é absorvido por 'tide'.
} 
A língua é um sistema. A língua é parte de uma cultura. Na prática translacional, há um sentido buscado em um texto numa língua e resistematizado em outra. Para a teoria do Escopo, o sentido é a referência; mais que tradução interlíngua, há uma tradução intercultural. O tradutor tem um papel essencial no processo, pois ele é leitor e escritor ao mesmo tempo, refletindo seus valores linguísticos e culturais; como qualquer pessoa, não vemos as coisas como elas são, mas sim como nós somos.

Sendo assim, um conceito muito importante para a teoria do Escopo é o conceito de equivalência. Segundo Reiss e Vermeer, equivalência "é a relação entre um texto alvo e um texto fonte que pode alcançar a mesma função comunicativa no mesmo nível nas duas culturas envolvidas"43 (REISS \& VERMEER, 2013, p. 128). Equivalência é um conceito relacionado ao produto ou ao resultado e alcançá-la "requer redefinir as prioridades de todos os fatores que influenciam o processo de tradução"44 (REISS \& VERMEER, 2013, p. 153).

Tem-se que uma ação translacional - em substituição ao termo tradução - é mais que intralingual ou interlingual; ela é intercultural. São vários os fatores que determinam o escopo da ação translacional intercultural, como tradições, sistemas de valores, normas e atitudes. A ideia é que não vemos as coisas como elas são, mas sim como nós somos. Levando isso em consideração, na prática translacional, "o significado é extraído de um texto fonte e então recodificado no texto alvo." 45 (REISS \& VERMEER, 2013, p. 29) Isso significa que o significado é o fator crucial da tradução, e o núcleo que deve se manter inalterado, ou constante. Uma ação translacional é uma oferta de informação. Como é uma forma específica de interação, "uma ação translacional é governada por seu propósito."46 (REISS \& VERMEER, 2013, p. 123)

Em suma, a teoria geral de ação translacional consiste em três suposições, a saber: uma ação translacional é uma função de seu escopo; uma ação translacional é uma oferta de informação para uma cultura e língua alvo sobre uma oferta de informação feita numa cultura e língua fonte; a informação alvo é representada por

\footnotetext{
43 "Equivalence is the relationship between a target text and a source text which (can) achieve the same communication function at the same level in the two cultures involved."

44 “... requires resetting the priority of all the factors influencing the translation process."

45 "In translational practice, the meaning is extracted from the given source text and then re-encoded in the target text."

46 “A translational action is governed by its purpose."
} 
uma transferência que simula a oferta de informação fonte. É um processo complexo que resulta num 'translatum' que deve ser coerente por si próprio e coerente com o texto fonte (REISS \& VERMEER, 2013), e que deve entender a equivalência como uma forma de adequação. Segundo Reiss \& Vermeer (2013, p. 128),

Em nossa definição, equivalência é um tipo específico de adequação, isto é, adequação na condição que o escopo exige para que tanto o texto fonte quanto o texto alvo atinjam a mesma função. ${ }^{47}$

Então, a equivalência textual é um conceito dinâmico relacionado ao escopo do texto alvo e à relevância dos elementos do texto, e com o escopo desse texto no processo de comunicação. Sob esse prisma, o foco do tradutor é primeiramente na "língua como um meio de comunicação, ainda que não no sentido de um uso da linguagem simples e unidirecional"48 (REISS \& VERMEER, 2013, p. 135) Mais que isso, a linguagem é uma ferramenta que facilita a comunicação do que uma cultura quer expressar.

E aqui o tradutor tem papel principal, pois ele, antes de tudo, é um leitor, com suas competências, sua compreensão individual do texto fonte, sua visão pessoal e padrões de qualidade, que vão determinar o processo de tradução. Ou seja, ele é um intermediador do processo de comunicação interlingual e intercultural. $\mathrm{O}$ caminho passa pelo emissor do texto, que oferece uma informação, engatilhando um processo de comunicação, e pelo texto em si, ou seja, a representação linguística da oferta de informação. A interação nesse processo vai determinar o sucesso da ação translacional.

Como todas as teorias que buscam explicar e multiplicar seus pressupostos, tanto a teoria do Escopo de Reiss e Vermeer quanto a teoria Funcionalista de Nord foram criticadas, principalmente por sua abordagem voltada para o alvo. As críticas são questionamentos referentes à intencionalidade, ao propósito e à orientação ao alvo e não à fonte, assim como indagações acerca do papel do tradutor, do status do texto original e de adaptações. Num âmbito mais teórico, questionou-se a possibilidade de teorias funcionalistas 'alongarem' demasiadamente os contornos do

\footnotetext{
47 "In our definition, equivalence is a particular kind of adequacy, i.e., adequacy under the condition that the skopos requires that the source and target texts achieve the same function."

48 "... language as a means of communication, although not in the sense of a simple, one-dimensional use of language."
} 
conceito de tradução, tornando-os um pouco vagos; além disso, a própria teoria foi criticada por não ser original e ser por demais prescritiva.

Em resposta às críticas e questionamentos, Nord (2014) faz uma listagem e explicita o posicionamento da Teoria do Escopo e de sua abordagem Funcionalista para cada um dos pontos mencionados. Toda teoria que vem a público passa a ser objeto de análise e escrutínio; é a argumentação e refutação que vão dar à teoria sustentação e possibilidade de amadurecimento e desenvolvimento. Em relação à crítica de que o funcionalismo não respeita o texto original, Nord (2014, p. 119) considera que:

\begin{abstract}
para responder a essa crítica, devo assinalar que as abordagens funcionalistas se baseiam num conceito sociológico do que é um texto. A forma com que um texto se apresenta a um tradutor é produto de muitas variáveis situacionais (tempo, lugar, destinatários) que o originaram, e a maneira como essa forma é interpretada e entendida pelo tradutor ou qualquer outro receptor é guiada pelas variáveis da nova situação de recepção, incluindo, claro, a competência do tradutor em análise de texto, o que pode ajudá-lo a relativizar seu próprio ponto de vista. ${ }^{49}$
\end{abstract}

A Teoria do Escopo foi, segundo Nord, o modelo translacional necessário para mudar paradigmas e responder ao foco cada vez mais intenso "na comunicação como ocorrência social e voltada à cultura, nos indivíduos envolvidos, nas condições espaço-temporais da comunicação, e nas intenções e funções comunicativas." 50 (NORD, 2014, p. 123). A teoria era pragmática, voltada à cultura, consistente, prática, normativa, abrangente e especializada.

Nord vai um pouco além e acrescenta à abordagem funcionalista o conceito de função mais lealdade (function plus loyalty), que são complementares, ainda que por vezes tais conceitos pareçam contraditórios. A função se refere aos "fatores que fazem com que o texto funcione da forma pretendida na situação alvo", ao passo que a lealdade se refere às "relações interpessoais entre o tradutor, o emissor do texto

\footnotetext{
49 "To answer this criticism, I should point out that functionalist approaches are based on a sociological concept of what a text is. The form in which the source text lies before the translator is a product of the many variables of the situation (time, place, addressees) in which it originated, and the way this form is interpreted and understood by the translator or any other receiver is guided by the variables of the new reception situation, including, of course, the translator's competence in text analysis, which may help them to relativize their own standpoint."

50 "....on communication as a social, culture-bound occurrence, on the individuals involved, on the spatiotemporal conditions of communication, and on communicative intentions and functions."
} 
fonte, os receptores no público alvo e o iniciador" ${ }^{\text {51 }}$ (NORD, 2014, p. 126). O princípio da lealdade acrescenta à teoria funcionalista duas qualidades importantes: ele faz com que a teoria do Escopo não seja universalista, pois o tradutor precisa estar ciente das diferenças entre as duas culturas, e reduz o caráter prescritivo do funcionalismo 'radical', pois induz o tradutor a respeitar as intenções comunicativas do emissor.

Essa abordagem vem ao encontro do tipo de estudo aqui pretendido, pois a Teoria do Escopo e a teoria Funcionalista se ocupam da função que o texto traduzido vai produzir no público receptor dos filmes legendados, isto é, a tradução é uma atividade com propósito. É imprescindível ter em conta aspectos culturais e pragmáticos da tradução, e informar aos receptores sobre o gênero, o valor artístico e a beleza do original, de certa forma mostrando que o texto original merece ser traduzido. A ação translacional é uma ação 'proposital':

No âmbito dessa teoria [do Escopo], um dos fatores mais importantes na determinação do propósito da uma tradução é o destinatário, que é o receptor ou público pretendido para o texto alvo, com seu conhecimento do mundo e da cultura, suas expectativas e suas necessidades comunicativas. ${ }^{52}$ (NORD, 2014, p. 12)

\section{2.... e Sensibilidade... - Razão e Sensibilidade ${ }^{53}$}

A ironia é o primeiro indício de que a consciência se tornou consciente.

Fernando Pessoa Livro do Desassossego

É mais fácil destruir um átomo do que um preconceito. Albert Einstein

\footnotetext{
51 “...factors that make a target text work in the intended way in the target situation. [...] interpersonal relationship between the translator, the source-text sender, the target-text addressees and the initiator." 52 "In the framework of this theory, one of the most important factors determining the purpose of a translation is the addressee, who is the intended receiver or audience of the target text with their culturespecific world-knowledge, their expectations and their communicative needs."

${ }^{53}$ Razão e sensibilidade (Sense and sensibility) é um drama de 1986 com o seguinte enredo: em virtude da morte do marido, uma viúva e as três filhas passam a enfrentar dificuldades financeiras, pois praticamente toda a herança foi para um filho do primeiro casamento, que ignora promessa feita no leito de morte de seu pai que ampararia as meias-irmãs. Neste contexto, enquanto uma irmã (Emma Thompson) é mais prática e usa a razão como principal forma de conduzir as situações, a outra (Kate Winslet) se mostra emotiva, sem se reprimir nunca com uma sensibilidade à flor da pele.
} 
Há muito mais na linguagem que a comunicação de fatos, ideias, pensamentos, opiniões, emoções. Ela contém também o não dito, o implícito, e as modulações do que é percebido como realidade, ou ainda, a pluralidade dessa percepção da realidade. Como visto acima, a linguagem do humor se manifesta de forma verbal e/ou visual; assim também com a linguagem sensível, que contém referências étnicas, sexuais, sociais, ou quaisquer outras que expressem susceptibilidades ou particularidades específicas a um grupo ou comunidade. São formas de expressão cultural, como coloca Carbonell (em ALVAREZ e VIDAL, 1996, p. 81):

Representação, estereotipagem, estratégias de significação e poder: a rede na qual uma cultura é elaborada parece uma textura de signos ligados por infinitas conotações e denotações, um sistema de significados de inextricável complexidade que é refletido, desenvolvido e registrado no multifacetado ato de escrever. ${ }^{54}$

"Semanticamente, vários significados são ativados por formas idênticas ou similares num texto" ${ }^{, 55}$ (VANDAELE, 2011, p. 180). Assim, será de extrema importância a intencionalidade do enunciado, sua significação dentro de cada cultura, e como ele é comunicado, interpretado, aceito, rechaçado, correspondido, aprovado ou desaprovado. Para examinar essa inter-trans-culturalidade, itens referenciais de manifestação dessa linguagem complexa e sensível serão explicitados a seguir, levando em consideração sua potencial tradução e sua inserção na cultura fonte e alvo, pois, segundo Krikmann (2006, p. 54), essa "experiência é um ato social bilateral e cooperativo" 56 :

Nosso condicionamento social significa que é gratificante ver narrativas onde a ostentação é esvaziada, a autoridade excessiva é frustrada, a modéstia é recompensada e a arrogância é punida. Não é surpreendente ver um ouvinte escolher, se tiver a opção, uma interpretação com a trajetória mais satisfatória. $^{57}$

\footnotetext{
54 "Representation, stereotyping, strategies of signification and power: the network in which a culture is fashioned does appear as a texture of signs linked by endless connotations and denotations, a meaning system of inextricable complexity that is reflected, developed and recorded in the multifarious act of writing."

55 "Semantically, several meanings are activated by identical or similar forms in a text."

56 "... is a two-sided, cooperative social act."

57 "Our social conditioning means it is gratifying to see narratives where pomposity is deflated, excessive authority is thwarted, modesty is rewarded and arrogance is punished. It should not be surprising then to see a listener choose, when given the freedom, an interpretation with the most satisfying trajectory."
} 


\subsubsection{Ironia, sarcasmo, duplo sentido}

A linguagem sensível é rica de insinuações, provocações, alusões e modulações. Por isso, definir essa linguagem sensível ou diferenciar suas manifestações - ironia, sarcasmo, logro, duplo sentido - é tarefa complexa pois, no dizer de Alba-Juez (2014, p. 6), "pesquisar a ironia mais cedo ou mais tarde se torna uma empreitada irônica, pois quanto mais se estuda e analisa, mais difícil é definir e estabelecer claras delimitações do fenômeno." 58

A ironia, como visto acima, é uma das manifestações da linguagem sensível, assim como o sarcasmo e as colocações de duplo sentido. Por sarcasmo pode-se entender um tipo de ironia mais amarga e provocatória, às vezes quase um insulto. A

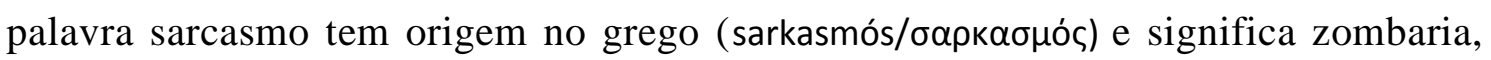
motejo, escárnio (http://www.significados.com.br/sarcasmo/); seria uma reação menos moderada que a ironia. Está presente na literatura como sátira, que tem a finalidade de apontar e ridicularizar defeitos, sejam de indivíduos ou de grupos. Por exemplo, dizer a um homem que a camisa dele é bonita e depois perguntar se na loja em que ele a comprou também vendia roupa masculina é um comentário sarcástico (e também sugerindo preconceito).

Já o duplo sentido pode ser visto como um tipo de trapaça linguística que, na alegação de Roland Barthes, o homem é prisioneiro irremediável da linguagem, e só pode se libertar por meio de uma 'trapaça' linguística, “essa trapaça salutar, essa esquiva, esse logro magnífico que permite ouvir a língua fora de seu poder, no esplendor de uma revolução permanente da linguagem, eu a chamo, quanto a mim: literatura" (SILVA, 2010, p. 294). É a fuga da linguagem pela própria linguagem. Em termos de linguagem sensível, o duplo sentido linguístico seria uma peculiaridade discursiva ligada "aos elementos integrantes das áreas da fonologia, da prosódia, da morfologia e/ou da sintaxe" (MARTINS e AMORIM, 2013) que, assim como a ironia e o sarcasmo, vai depender do trinômio emissor-contexto-receptor.

O enfoque dessa sessão será a ironia, pois nela se encaixam as outras formas de manipulação linguística; considera-se aqui a ironia como um conceito 'guardachuva', mais abrangente, apesar de não ter um “conjunto fixo de características

\footnotetext{
58 “....doing research on irony sooner or later becomes an ironic enterprise, for the more one studies and analyzes it, the more difficult it is to define and set clear and tidy boundaries to the phenomenon."
} 
linguísticas ou estilísticas: não há um tom ou um estilo irônico reconhecível” (MATEO, 2010, p. 198). As representações de sarcasmo e duplo sentido estão, de certa forma, incorporadas nesse mesmo âmbito, pois, de acordo com Eleni Kapogianni (2011, p. 4):

A ironia, como um termo guarda-chuva para diferentes manifestações como ironia situacional, ironia trágica e ironia verbal, é basicamente caracterizada pela existência de dualidade e contraste. Isso significa que o fenômeno da ironia pressupõe a existência de um contraste facilmente perceptível entre dois opostos. ${ }^{59}$

A ideia de que a ironia é dizer uma coisa querendo dizer outra não é suficientemente abrangente para uma definição, principalmente em se tratando de ironia verbal. Como apontado por Alba-Juez (2014, p. 6), "a distinção entre ironia e não ironia não é binária, mas sim um contínuo." ${ }^{60}$ Assim como não há palavras ou expressões humorísticas por si só, mas que se tornam humorísticas pelo uso semântico ou sintático num contexto, tampouco há palavras ou expressões que definam a ironia. A ironia, como uma contradição inferida, ativa uma série de interpretações subversivas que diferem de trocadilhos ou jogos de palavras; "a dupla interpretação da ironia é, portanto, diferente daquela do jogo de palavras, que é produto de uma estrutura linguística e que implica questões de significado e não de interpretação" (MATEO, 2010, p. 198).

O fenômeno da ironia é estudado há bastante tempo; Sócrates já a utilizava, quando fingia ignorância para ensinar. Já Cícero considerava a ironia como uma "figura retórica que culpa pelo elogio ou elogia pela culpa"61 (ALBA-JUEZ, 2014, p.6), se aproximando do que hoje seria a ironia situacional e verbal. Mais tarde, em Roma, Quintiliano expandiu a teoria e colocou a ironia como uma figura de linguagem, para dizer "o contrário do que é dito, um disfarce do completo significado do falante" ${ }^{62}$ (id., 2014, p. 7). Todas essas premissas partem do princípio que a ironia é sempre falsa ou insincera.

\footnotetext{
59 "Irony, as an umbrella term for a number of different manifestations such as situational irony, tragic irony and verbal irony, is basically characterized by the existence of duality and contrast. This means that the phenomenon of irony presupposes the existence of an easily detectable contrast between two counterparts."

60 “...irony versus non-irony is not a binary distinction but rather a continuum."

61 " "... a rhetorical figure that blames by praise or praises by blame."

62 "the contrary of what is said", "a disguise of the speaker's whole meaning".
} 
A ironia é um fenômeno pragmático, que surge "quando há algum tipo de contraste ou incongruência entre o que é dito (o conteúdo proposicional) e o que pode ser inferido da situação"63 (PELSMAEKERS e VAN BESIEN, 2002, p. 243). Essa incongruência pode ser uma oposição real, um eufemismo, ou um exagero. Muecke (MATEO, 2010, p. 198) aponta três elementos básicos para se chegar à ironia: é necessário que a situação a) seja apresentada em dois níveis, o inferior - ou a situação como aparece para a 'vítima' da ironia - e o superior - a situação do ponto de vista de quem a elabora; b) haja alguma oposição entre os dois; e c) inocência, isto é, o desconhecimento da existência dos dois níveis - ou a suposição desse desconhecimento.

Segundo Austin (PELSMAKERS e VAN BESIEN, 2002), todo ato de fala externa um ato locucionário, ilocucionário, e perlocucionário. Um ato locucionário é o próprio ato da fala; o ato ilocucionário se apresenta como uma afirmação, promessa, pergunta e assim por diante; e o ato perlocucionário é o efeito provocado pela locução. Por exemplo, se alguém diz: "você está sentado na minha poltrona", o ato locucionário é a própria fala; o ato ilocucionário é uma constatação e um tipo de protesto; e o ato perlocucionário é o de provocar um efeito em outra pessoa, no caso fazer com que ela saia da poltrona. No caso da ironia, em vez de ato locucionário, teríamos uma incongruência locucionária e uma incongruência ilocucionária geralmente, em forma de crítica -, que vão gerar efeitos perlocucionários, ou seja, criticar ou censurar e, ao mesmo tempo, criar algum tipo de divertimento ou distração.

Esse sentimento de contradição se relaciona diretamente aos fatores que afetam a percepção correta ou incorreta da ironia, e é ele que distingue a ironia do sarcasmo:

\footnotetext{
a ironia 'mal codificada' interpreta mal o real contexto da mensagem para que as contradições tenham que ser entendidas como normais, enquanto que uma afirmação sarcástica é aparentemente sincera e não provoca nenhum sentimento de contradição (MATEO, 2010, p. 199).
}

Esses fatores que afetam a percepção da ironia são: a capacidade de ser irônico e a percepção do receptor; as regras aceitas tanto por emissor quanto por

\footnotetext{
63 “....irony arises when there is some kind of contrast or incongruity between what is said (the propositional content) and what can be inferred from the situation."
} 
receptor e a familiaridade deles com elas; e a probabilidade de haver uma intenção irônica.

No contexto da percepção da ironia, e de acordo com o Princípio Cooperativo de Grice e suas máximas,

\begin{abstract}
há um acordo tácito entre os participantes em uma conversação de ambos fornecerem informação suficiente e apropriada (máxima da Quantidade), e fazerem contribuições que sejam verdadeiras e não dizerem nada que um acredite ser falso (Qualidade), dizer o que é relevante (Relação), e ser breve e ordenado, e evitar obscuridade e ambiguidade (Modo). A competência comunicativa do ouvinte o habilita a perceber quando o falante está transgredindo essas máximas e sendo irônico (MATEO, 2010, p. 200).
\end{abstract}

Levando tais princípios em consideração, a ironia surge de vários fatores e pode ser classificada em dois tipos, segundo Mateo (2010, p. 201): ironia intencional ou linguística versus ironia não intencional ou dramática, cuja diferença reside no discernimento ou não da intenção de produzir uma locução contraditória. Já Muecke (MATEO, 2010, p. 201) distingue quatro modos irônicos: ironia impessoal, em que a ironia está no que é dito, não em quem diz; ironia auto depreciativa, em que o ironista se mostra ignorante; ironia ingênua, em que há um afastamento do ironista, que provoca a ironia por meio de um personagem; e ironia dramatizada, em que a situação irônica é simplesmente apresentada pelo ironista, sem envolvimento dele. No espectro da ironia impessoal, encontram-se diversas técnicas, entre elas elogiar para culpar e vice-versa, pretensa dúvida, ironia por analogia, pretenso erro ou ignorância, contradição interna, raciocínio falacioso, paródia, alusão e insinuação, entre outras.

Sabe-se como a ironia é usada, mas não o porquê. Normalmente o ironista quer dizer muito mais do que diz. Dews, Kaplan e Winner (CONZ, 2010, p. 43), investigaram quatro funções da ironia: humor, que torna a crítica implítcita na ironia mais aceitável; status de elevação, que torna a crítica irônica mais forte que a literal; agressividade, pois a crítica irônica pode ser mais maldosa que a literal, e ainda deixa a interpretação sob a responsabilidade do ouvinte; e controle emocional, pois a suposta 'brincadeira' faz com que o ouvinte se sinta menos insultado.

A partir do momento em que compreendemos um enunciado como sendo irônico, tornamo-nos conscientes de que algo além do óbvio ou do literal está sendo dito e temos que estar prontos para inferir o que realmente se quer dizer (CONZ, 2010, p. 47). 
Das máximas Griceanas, Sperber e Wilson (CONZ, 2010, p. 24) utilizam a da relevância - aqui vista como os enunciados que geram expectativas não por alguma convenção linguística ou comunicativa, mas como uma busca comunicativa inerente à cognição humana - para esclarecer que a ironia envolve a expressão de uma atitude "e sua relevância depende, pelo menos em partes, da informação transmitida sobre a atitude do falante" (CONZ, 2010, p. 25). Tais atitudes são ilimitadas e podem indicar endosso ou dissociação do enunciado, demonstrando incerteza, ceticismo, raiva, e outros.

\footnotetext{
$\mathrm{Na}$ abordagem teórica da relevância, a ironia verbal envolve a expressão de uma atitude tacitamente dissociativa - enviesada, cética, amarga ou arremedada - em relação a um enunciado ou pensamento atribuído. [...] Ironia verbal consiste em ecoar um pensamento ou enunciado implicitamente atribuído com uma atitude tacitamente dissociativa (Sperber e Wilson, apud CONZ, 2010, p. 25).
}

Outra visão para o reconhecimento da ironia verbal é a de encontrar um denominador comum destacando algum tipo de "expectativa, desejo, regra social, entre outros, que foi violado" (CONZ, 2010, p. 29). Esse tipo de referência a expectativas violadas foi chamado de pretensão alusional por Kumon-Nakamura et al (id., 2010, p. 29). Para esses autores, todo enunciado irônico faz referência à oposição entre o que ocorre e o que deveria ter ocorrido; esse enunciado tem algum grau de insinceridade pragmática, ou seja, não é patente, pois, se a insinceridade for ostensiva, o enunciado deixa de ser irônico.

Em relação ao vínculo entre ironia e sarcasmo, Conz (2010, p. 39) afirma que esta é uma relação íntima, já que "ambos tendem a ser usados para se fazer um enunciado que tenha conotação emocional." Os dois se confundem, mas pode-se dizer que o sarcasmo é uma forma de humor, ao passo que a ironia pode ou não ser humorística. Aqui há um fator interessante a ser considerado: a entonação. Contexto e entonação são pistas inconfundíveis para a identificação da ironia ou do sarcasmo, assim como certas pistas verbais - hipérbole, metáforas, interjeições, tom de voz - e pistas não verbais, como a expressão facial e gestos.

Sejam quais forem as técnicas utilizadas para identificar ou criar a ironia - e o sarcasmo, e o duplo sentido - há sempre a necessidade de cooperação entre o emissor e o receptor. No caso do humor, trata-se de uma parceria entre o contador da piada e o receptor; no caso da ironia, parece ser mais uma conspiração entre eles. $\mathrm{O}$ 
contexto tem papel crucial na criação da ironia, e é necessário um "conhecimento prévio de natureza sócio-cultural para se poder saborear a ironia” (MATEO, 2010, p. 205). Para exemplificar essa composição ironia-sarcasmo-duplo sentido, a afirmação: 'você parece estar em plena forma...' - para alguém que visivelmente não está em forma - é um comentário irônico; se houver a continuação: ‘...de barril', já é uma crítica mais sarcástica. Se for acrescentada a frase: 'redondo é uma forma', pode-se dizer que é uma afirmativa com duplo sentido (no contexto).

Nessa vertente, a Teoria dos Dois Scripts e a Teoria Geral do Humor Verbal surgem como ferramentas para interpretar e entender as piadas, e Raskin e Attardo enfatizaram a perspectiva linguística da abordagem. No entanto, essas teorias podem também ser aplicadas a outros gêneros verbais ou sistemas semióticos, como a ironia ou a linguagem erótica. Há uma clara correspondência relacionada à oposição de scripts e suas ferramentas. A ironia, por exemplo, depende do contexto. Não há um conjunto fixo de características linguísticas ou estilísticas que definam a ironia. Segundo Mateo,

\footnotetext{
Da mesma maneira como não há palavras ou expressões que sejam humorísticas por si só, mas pelo seu uso semântico ou sintático em um contexto, e que terão de ser definidas "extrinsecamente" por suas conexões contextuais e relações semânticas, assim também a ironia depende de um contexto, uma vez que surge das relações de uma palavra, expressão ou ação com o texto ou uma situação inteira. (MATEO, 2010, p. 198)
}

Em suma, o que difere a ironia do jogo de palavras do humor é que este é o produto de uma estrutura linguística e que implica questões de significado e não de interpretação. A oposição entre os dois níveis da ironia precisa apresentar um sentimento de ambiguidade, pois realidade e aparência devem "estar presentes como verdadeiras" (MATEO, 2010, p. 198). A ironia expressa, pois, duas realidades opostas como verdadeiras, não implicando propósito de enganar.

Diferentemente do engano, em que o contraste entre os dois níveis pretende esconder um sentido verdadeiro, a ironia tem a intenção de ser entendida e o reconhecimento do real sentido, ou melhor, do fato de que há um real sentido diferente daquele que está sendo enunciado, é essencial para a obtenção do efeito irônico completo. (MATEO, 2010, p. 199)

\subsubsection{Preconceito, tabu, linguagem erótica}


Dentre todas as formas de comunicação, talvez a mais sensível seja a linguagem que externa preconceitos, tabus, erotismo, pois é a que mais exterioriza julgamentos de valor, crenças e convicções relativas à nossa visão do mundo e de nosso papel nele. Esse tipo de linguagem revela, mais que tudo, uma atitude que leva a predisposições e tendências comportamentais. Uma atitude se compõe de três elementos: um elemento cognitivo (referência a um objeto, que pode ser uma abstração, uma pessoa, um grupo ou instituição), um elemento afetivo (o valor que gera sentimentos positivos ou negativos e, consequentemente, atitudes também positivas ou negativas) e um elemento comportamental (predisposição de se aproximar ou se esquivar do objeto).

Essa prenoção é histórica e socialmente construída, segundo a definição de Gordon Allport (SILVA, 2007), psicólogo social que discorreu sobre a natureza do preconceito. Foi ele que mencionou a influência de "traços de personalidade, emoções e cognições no aparecimento do preconceito" (id., 2007, p. 57). De acordo com Gaines \& Reed (1995, apud SILVA, 2007, p. 57):

\footnotetext{
...segregação, preconceito e discriminação (...) não são resultados inevitáveis de processos biológicos ou cognitivos. Argumentamos, pelo contrário, que eles refletem a emergência histórica de comportamentos e sistemas de crenças específicas que equacionam diferenças físicas e culturais com "bondade" ou "maldade" dentro da espécie humana. Tais comportamentos e crenças surgirão apenas como uma consequência de histórias de opressão particulares.
}

Então o preconceito é "uma atitude hostil ou negativa para com determinado grupo, baseada em generalizações deformadas ou incompletas" (SILVA, 2007, p. 57). Esse é o chamado estereótipo, que seria causa e consequência do preconceito. $\mathrm{O}$ termo refere-se a crenças compartilhadas sobre atributos ou comportamentos usuais de pessoas ou grupos. O que é percebido como similar nos faz agir de acordo com essa percepção. O estereótipo é um “comportamento funcional e adaptativo, pois com frequência é uma forma de simplificar e agilizar nossa visão do mundo" (Paul, 1998, apud SILVA, 2007, p. 59). Em suma, um atalho para entender o mundo cuja possível consequência negativa é a generalização incorreta e rotuladora. Quando uma primeira impressão é guiada por um estereótipo, a tendência é deduzir coisas sobre ela de maneira imprecisa, assim perpetuando o estereótipo inicial. 
Já o tabu pode ser definido como "a proibição ou fuga, em qualquer sociedade, de comportamento potencialmente danoso para seus membros, podendo causar ansiedade, constrangimento, ou vergonha",64 (Wardhaugh, 2000, apud GAO, 2013, p. 2311). A palavra tabu vem da língua tonganesa, e significa 'sagrado' ou 'intocável'. Os assuntos tabus variam, mas em geral são assuntos referentes a sexo, morte, doença, secreções, funções orgânicas, assuntos religiosos, o supernatural, podendo se estender a outros aspectos da vida social.

No que diz respeito à manifestação desses tabus na linguagem, a inclinação é tentar amenizá-los e ou usar eufemismos - palavras ou expressões que neutralizam a agressividade - para evitar aborrecimentos e situações constrangedoras ou para proteger os sentimentos individuais. Segundo Orsi (2011, p. 336),

um tabu linguístico é decorrente das sanções, restrições e escrúpulos sociais; atua na não permissão ou na interdição de se pronunciar ou dizer certos itens lexicais aos quais se atribui algum poder e que, se violados, poderão trazer perseguições e castigos para quem os emprega.

Por vezes, a comunicação de pensamentos e emoções esbarra em preconceitos e tabus que "limitam ou modificam sua linguagem" (ORSI, 2011, p. 340). Essa limitação ou modificação pode se manifestar com um léxico erótico ou obsceno, com um palavrão - segundo Tartamella (apud ORSI, 2011, p. 335), um projétil verbal - ou até mesmo com o abrandamento de tal linguagem. O palavrão, por exemplo, é um elemento de catarse mal aceito pelas convenções sociais, o que o torna um tabu linguístico. Tal linguagem chula tem força expressiva de acordo com a carga semântica que é atribuída a ela: usada "na situação adequada, funciona como notas musicais para criar um determinado efeito na partitura, ou melhor, no discurso" (ORSI, 2011, p. 337). Podem-se usar também eufemismos e metáforas, sendo a opção dependente do ambiente cultural e do contexto.

Em relação à linguagem referente ao sexo e com conteúdo erótico, Santaemilia (2005, p. 3) afirma que é uma linguagem que permeia todos os tipos de texto:

sexo (sexualidade) é um discurso que se encontra na intersecção de pelos menos duas forças incontestáveis: por um lado, uma experiência privada e

\footnotetext{
64 “... taboo is the prohibition or avoidance in any society of behavior believed to be harmful to its
} members in that it would cause them anxiety, embarrassment, or shame." 
íntima que articula nossas vozes e nossos desejos; e por outro lado, um complexo processo de construção discursiva que é profundamente ideológica e altamente dependente da moralidade de cada período histórico, da instável dialética entre valores individuais e disciplina social. ${ }^{65}$

Trata-se de um discurso que está sempre presente, e ao mesmo tempo, é velado. Por isso, tanto eufemismos quanto disfemismos ${ }^{66}$ são utilizados para falar de sexo ou de qualquer linguagem que tenha referências sexuais - ou obscenas, ou eróticas. O uso do eufemismo protege valores sociais; o uso de disfemismos provoca rejeição moral. A reação à exposição à linguagem sexual depende de "suposições ou expectativas culturais, da atitude da época em relação ao corpo, à sexualidade ou a diferentes identidades sexuais"67 (SANTAEMILIA, 2005, p. 12). É uma linguagem vista de forma diferenciada em cada sociedade ou período, que vai usar, abusar ou evitar a referência de acordo com essa visão interlinguística e intercultural. "A linguagem do sexo serve para metaforizar nossos medos e ansiedades"68 (id., 2005, p. 16).

Enfim, a linguagem do sexo revela e reforça ideologias; ela dá origem a diferentes textos e discursos, registros e paradigmas, e é um mecanismo bastante poderoso. Como esclarece Santaemilia (2005, p. 15),

A linguagem sexual é talvez uma das melhores fontes de construção de identidade, de metáforas ideológicas, de narrativas que revolvem em torno do eu e que tentam defini-lo. O sexo origina discursos complexos (no senso Foucauldiano) em uma multiplicidade de níveis - pessoal, social, textual, cultural, histórico, etc. - que profundamente determinam nossa linguagem e nossa atitude. ${ }^{69}$

Por ser a linguagem erótica tão insidiosa e constante na comunicação, sua tradução demanda atenção especial e particularizada para não perder seu colorido; a

\footnotetext{
65 "Sex(uality) is a discourse which stands at the crossroads of at least two compelling forces: on the one hand, a private and intimate experience which articulates our voices and our desires; and on the other hand, a complex process of discursive construction which is profoundly ideological and highly dependent on the morality of each historical period, on the changeable dialectics between individual values and social discipline."

${ }^{66}$ Eufemismo = figura de linguagem que emprega termos mais agradáveis para suavizar o discurso.

Disfemismo (ou cacofemismo) = figura de linguagem que consiste em empregar deliberadamente termos ou expressões depreciativas, sarcásticas ou chulas para se referir a algum tema, coisa ou pessoa.

67 “...depends on cultural assumptions or expectations, on the period's attitude towards the body, sexuality or differing sexual identities."

68 "The language of sex serves to metaphorize our fears and anxieties."

69 "Sexual language is perhaps one of the best sources of identity construction, of ideological metaphors, or narrative which revolve around the self and try to define it. Sex originates complex discourses (in the Foucauldian sense) at a multiplicity of levels - personal, social, textual, cultural, historical, etc. - which strongly determine our language and our attitude."
} 
possibilidade de uma tradução 'neutra' não se aplica, "pois o material a trasladar a outra cultura é muito sensível e constitui o crisol de nossos preconceitos e nossos tabus mais profundos"70 (SANTAEMILIA, 2010, p. 128). A tradução de referências sexuais impõe limites discursivos que são uma reação aos valores e crenças de cada sociedade em um determinado momento histórico.

Outro aspecto importante a ser considerado na tradução da linguagem sensível é o contexto; é necessário um conhecimento sociocultural prévio para se 'saborear' o humor, a ironia, o sarcasmo, ou alguma alusão sexual. O contexto é essencial para tomar a ideia ou intenção original e adaptá-la à cultura alvo, para provocar uma resposta equivalente. Esse efeito equivalente é, na verdade, bastante intuitivo, pois não há como ser medido ou previsto por meio de alguma base objetiva. No entanto, como a equivalência é percebida mais gradual que absoluta, quanto mais a tradução se aproxima da fonte, "tanto em termos de forma e função, mais bem sucedida ela será" ${ }^{71}$ (CHIARO, 2012, p. 2).

Levando isso em consideração, Mateo (2010, p. 207) propõe uma pesquisa descritiva das estratégias tradutórias utilizadas para traduzir o humor e a linguagem sensível. Tais estratégias podem ser cotejadas com algumas estratégias já apresentadas acima; elas apenas enfocam as 'sub-estratégias', ou seja, as intenções de elogiar para culpar, expor contradições internas, insinuar, dramatizar, aludir ou parodiar. O que fica patente é que não há uma determinação absolutista em relação a quê ou como na tradução do humor ou da linguagem sensível; não há princípios universais. "Talvez um universal linguístico seja que nenhum grupo social usa a linguagem aleatoriamente"72 (GAO, 2013, p. 2313).

\footnotetext{
70 “....pues el material a trasladar a otra cultura es muy sensible y constituye el crisol de nuestros prejuicios y nuestros tabúes más profundos."

71 "...both in terms of form and function, the more successful it will be."

72 "Perhaps one linguistic universal is that no social group uses language quite at random."
} 


\section{3... na Tradução - Muito Além do Jardim ${ }^{73}$}

"Without translation,

we would be living in provinces bordering on silence." 74

George Steiner

Tudo é tradução. Desde Babel e a cizânia linguística despertada pela ira divina de ter seus domínios invadidos por iconoclastas inconformados com a impossibilidade de ver Deus que a tradução é instrumento fundamental de compreensão e comunicação. Talvez a alegoria babélica seja a metáfora ideal para a criação das várias línguas faladas no mundo; na mesma ocasião de tal criação, nasceu também a melancolia do tradutor que, segundo Lages (2007), em seu ato tradutório rememora Deus, sem jamais alcançar tal divindade ${ }^{75}$. Mas nem tudo é a melancolia da incompletude; do mito de Babel originou-se também uma infinita possibilidade de variações e cooperações, de tonalidades e musicalidades linguísticas, todas à espera de tradução, de propagação, de estranhamento e reconhecimento, de desdobramento e encontro.

A tradução é uma operação linguística por excelência. É também, nas palavras de Gregory Rabassa (GUZMÁN, 2008, p. 217), "uma travessia"76, com um caminho e uma finalidade, sem contudo perder sua natureza criativa. Mas, no questionamento de Rosas (2002, p. 76),

é difícil definir até que ponto a língua é um reflexo de hábitos e comportamentos que simplesmente 'existem' e até que ponto ela é uma arma de manejo estratégico na criação e na transformação daquilo que percebemos como 'realidade'.

\footnotetext{
${ }^{73}$ Muito além do jardim (Being there) é uma comédia dramática de 1979 que conta a história de Chance (Peter Sellers), um homem ingênuo, que passa toda a sua vida cuidando de um jardim e vendo televisão, seu único contato com o mundo. Nunca entrou num carro, não sabe ler ou escrever, não tem carteira de identidade, resumindo: não existe oficialmente. Quando seu patrão morre, é obrigado a deixar a casa em que sempre viveu e, acidentalmente, é atropelado pelo automóvel de Benjamin Rand (Melvyn Douglas), um grande magnata que se torna seu amigo e chega a apresenta-lo ao presidente (Jack Warden). Curiosamente, tudo dito por Chance ou até mesmo seu silêncio é considerado genial. Paralelamente, a saúde de Benjamin está crítica e Eve Rand (Shirley MacLaine), sua esposa, se apaixona por Chance.

74 “Sem tradução, estaríamos vivendo em províncias limítrofes ao silêncio."

75 "Segundo a interpretação tradicional do mítico relato bíblico, a criação de múltiplas línguas se deu em decorrência do castigo de Deus para o desejo de onipotência do homem, que aspirava, por meio da construção da torre, alçar-se às mesmas divinas alturas, ou seja, pretendia disputar o lugar de autoridade de Deus. Do ponto de vista da história e da teoria da tradução, pois, in principio fuit Babel: confusão, introdução da multiplicidade, da diferenciação no seio de uma desejada, suposta, plenitude linguística originária." (LAGES, 2007, P. 29/30)

76 "a setting-over"
} 
Nessa linha de pensamento, traduzir um texto humorístico, ou que contenha linguagem sensível, apresentaria problemas quando não há "compartilhamento de referências culturais entre os membros das línguas-culturas envolvidas e [quando] não há correspondência, em algum nível linguístico, entre as estruturas dessas línguas-culturas" (ROSAS, 2002, p. 89).

As estratégias tradutórias de humor verbal - e também da ironia, do sarcasmo, e de outras formas linguística e/ou culturalmente sensíveis incluem: a) humor/ironia no texto fonte vira humor/ironia no texto alvo por tradução literal; b) humor/ironia no texto fonte se torna humor/ironia no texto alvo por equivalência; c) humor/ironia se torna humor/ironia no texto alvo de forma diferente; d) humor/ironia é realçado no texto alvo com alguma palavra ou expressão; e) humor/ironia torna-se mais restrito ou explícito no texto alvo; f) humor/ironia torna-se sarcasmo; g) humor velado/ironia velada no texto fonte vem à superfície no texto alvo - perde-se a ironia; h) ambiguidade irônica ou humorística se perde na tradução; i) humor/ironia é substituída no texto alvo sem as oposições, eliminando as duas possíveis interpretações; j) humor/ironia é explicado em notas de rodapé no texto alvo; k) humor/ironia no texto fonte tem tradução literal, sem humor/ironia no texto alvo; 1) humor/ironia completamente suprimido no texto alvo; e m) o que não é humorístico ou irônico no texto fonte torna-se humorístico ou irônico no texto alvo.

É importante salientar o que Maria José Veiga chamou de Competência Tradutória de Humor Audiovisual. Os requisitos para alcançar tal competência seriam "eficiência, adequação e eficácia" (VEIGA, 2009, p. 9). A eficiência preconiza que a comunicação deve acontecer com um mínimo de esforço dos participantes, resultando possivelmente em reduções e elipses, e ao mesmo tempo objetivando um texto aceitável e relevante. Em termos de adequação, elementos como intertextualidade e contexto podem ser limitantes; por isso, a tradução audiovisual deve mostrar sensibilidade humorística e relevância. A eficácia vai se apresentar na produção bem sucedida da instância humorística. Segundo Beaugrande \& Dressler (VEIGA, 2009, p. 9), os sete padrões ou elementos de textualidade que devem ser seguidos são: “coesão, coerência, intencionalidade, aceitabilidade, informação, situação e intertextualidade" ${ }^{\text {77 }}$.

77 “...cohesion, coherence, intentionality, acceptability, informativity, situationality, and intertextuality.” 
A intenção final seria desenvolver uma "cumplicidade humorística", isto é, aprender a "conversar" com o texto fonte para "mediar" a recriação do humor no texto alvo, de maneira que ele não caia num vácuo tradutório onde a piada se perde, a ironia é suprimida, os estereótipos são desvirtuados e as referências culturais são excluídas. Os elementos constitutivos dessa Competência Tradutória são: Competência Técnica, ou seja, domínio das técnicas de legendagem; Competência Tradutória, tanto linguística quanto comunicativa; e Cumplicidade Humorística, isto é, sensibilidade e consciência do humor.

Ainda, há que se considerar os fatores externos que influenciam a tradução de humor audiovisual. Segundo De Rosa, é necessário distinguir o humor línguacultural do humor linguístico. Por humor língua-cultural, entende-se toda forma de humor "cujo conteúdo cômico se baseia numa interação conjunta de elementos verbais e culturais"(DE ROSA, 2011, p. 6), como menções a personagens famosos, culinária local e semelhantes; e o humor linguístico é transmitido "principalmente por meio da comunicação verbal, dos simples sons até as piadas baseadas em jogos de palavras, alusões, etc.” (id., p. 7). Já segundo Shipley (2007, p. 985), há as considerações sobre: a) Intervalo de Tempo, ou seja, quão recente a referência humorística ou irônica é, o que vai influenciar a compreensão da intenção do texto; b) as considerações sobre Classe Social e Educacional, que se refere quase sempre ao alvo das piadas ou comentários jocosos e irônicos, possivelmente limitando a percepção; c) as decisões de caráter cultural, que frequentemente recaem sobre o tradutor, que vai decidir quais elementos traduzir, levando em conta sua própria percepção cultural; e d) as informações sobre a publicação, que vão influenciar a escolha do texto a ser traduzido, assim como o tipo de tradução e tradutor. Todos esses fatores devem ser levados em consideração na tradução de humor e da linguagem sensível. ${ }^{78}$

As teorias de tradução de humor se baseiam não só no tipo de piada que vai ser traduzida - trocadilho, chiste, jogo de palavras - mas também nas teorias de superioridade e incoerência. De acordo com Liberatti (2011), o riso pode surgir da sensação de superioridade de um indivíduo frente a outro ou a alguma situação, em geral depreciativa, ou pode ser proveniente da incoerência como força motriz de

\footnotetext{
78 “Time Frame Considerations, Social-class and Educational Considerations, Cultural Awareness Decisions, and Publication Background Information.
} 
toda situação cômica. Nesse caso, "o humor é tido como forte dissolução de uma atitude, que é causada pela associação de duas ideias inicialmente distantes" (LIBERATTI, 2011, p. 222). Por fim, para que a piada tenha aceitação, é essencial que os 'leitores' da piada estejam inteirados das ideias opostas (oposição de scripts) que se apresentam numa situação. E o tradutor deve se informar sobre os aspectos socioculturais do público leitor para estabelecer as relações inusitadas que vão gerar o humor.

Tal humor, segundo Veiga (2009, p. 3), é uma manifestação psicológica e cognitiva, diferente do riso, que é um fenômeno neurofisiológico e não necessariamente relacionado ao humor. Ele também é um conceito relativo e subjetivo, que pode ser diferente de uma pessoa para outra, de um contexto a outro, de uma cultura a outra. Um fator é inegável: humor e inteligência são correlatos, o que leva à inferência que a tradução de humor requer um tipo de inteligência refinada e qualificada, para demonstrar, no texto alvo, as idiossincrasias e meandros do texto fonte.

De certa forma, e de uma maneira quase intuitiva, os mesmos princípios se aplicam à tradução de linguagem sensível - ironia, tabu, preconceito, linguagem erótica - pois as estratégias tradutórias acabam se assemelhando. Uma possibilidade para a tradução de humor e da linguagem sensível, como já descrito e detalhado anteriormente, seria a Skopostheorie (Teoria do Escopo) proposta por Katharina Reiss e Hans Vermeer em 1985. Por tratar-se de uma abordagem funcionalista e pragmática da tradução, a tradução torna-se translação ou ação translativa, que pressupõe que

\footnotetext{
quando alguém traduz ou interpreta, produz um texto. A tradução/interpretação também deve funcionar de forma ótima para a finalidade prevista. Eis aqui o princípio fundamental de nossa teoria da translação. O que está em jogo é a capacidade de funcionamento do translatum (o resultado da translação) numa determinada situação, e não a transferência linguística com a maior "fidelidade" possível a um texto de partida [...], concebido sempre em outras condições, para outra situação e para "usuários" distintos dos do texto final. (REISS e VERMEER, apud ROSAS, 2003, p. 145)
}

A teoria do escopo indica uma ação complexa, pois parte de uma situação em que uma primeira ação já existe; então, a decisão do tradutor é se e o que traduzir, bem como a estratégia a seguir. O princípio dominante da translação é sua 
finalidade, ou a função da ação translatória, que serve para se alcançar um objetivo. Em suma, "o que se faz é secundário diante do objetivo da ação e sua consecução" (ROSAS, 2003, p. 146). Para que se defina a decisão funcional de uma 'translação', três fases devem ser abordadas: 1. a determinação do escopo - saber quem são os receptores finais; 2. a atribuição de novos valores às partes do texto de partida - que modificações são necessárias; e 3. a realização do escopo - texto produzido a partir da avaliação feita pelo tradutor das expectativas do receptor, implicando uma transferência cultural e linguística.

Segundo a teoria do escopo, o tradutor sempre age intencionalmente, ou seja, com um propósito - há uma razão para toda ação. Nessa linha de raciocínio, Christiane Nord (2005, p. 24) desenvolve a diferença entre ação translatória e tradução. A primeira é a variedade de coisas que o tradutor faz durante todo o seu trabalho, como analisar os aspectos culturais de ambas as línguas. Já a tradução é o que o tradutor verdadeiramente faz enquanto verte o texto para a língua de chegada. Para Nord, a tarefa do tradutor seria: a) analisar a aceitação e viabilidade da tradução; b) verificar se a tradução é realmente necessária; c) especificar as atividades necessárias para realizar a tradução; e d) executar a ação translacional. "A função da tradução não reside no texto de partida. Um mesmo texto pode originar diferentes tipos de tradução, dependendo da situação em que a tradução será utilizada" (ENOMOTO, 2005, p. 18).

Resumindo o que já foi detalhado anteriormente, Christiane Nord (2005) sistematizou as ideias propostas na Teoria do Escopo de Hans Vermeer e Katharina Reiss e propôs uma abordagem funcionalista de propósito comunicativo com foco específico na tradução, com base nas três funções básicas da língua: a referencial, a expressiva e a apelativa. Além dessas, Nord propõe uma quarta função, a função fática. Para fins tradutórios - ou melhor, translatórios - todas essas funções podem apresentar dificuldades.

Recapitulando e exemplificando, a função referencial envolve a referência a objetos e fenômenos do mundo, e traduzir essas referências terá maior ou menor grau de dificuldade dependendo do conhecimento compartilhado entre as culturas. A função expressiva se refere à atitude do 'emissor' ao mundo em sua volta; a dificuldade translatória seria interpretar o texto fonte nos termos do sistema de valores da cultura fonte. A função apelativa, como diz o nome, apela à sensibilidade 
do receptor e sua disposição a responder de uma maneira específica; a ação translatória vai exigir familiaridade e aproximação ao sistema de valores da cultura alvo. Por fim, a função fática tenta abrir e fechar o canal entre o emissor e o receptor, deixando-o aberto o necessário para que haja comunicação. A função fática se baseia nas convenções linguísticas, não linguísticas e paralinguísticas; na tradução, "quanto mais convencional a forma linguística, menos reparamos nela"79 (NORD, 2014, p. 44). O problema se dá quando uma forma que é convencional numa cultura não o é em outra.

As diferentes funções comunicativas vão exigir estratégias tradutórias diferentes. Se a finalidade de uma tradução é manter o texto fonte invariável, os marcadores de função devem ser adaptados aos padrões da cultura alvo; caso contrário - se os marcadores da cultura fonte forem reproduzidos rigorosamente - os receptores da mensagem podem atribuir uma função diferente a esse texto. Por exemplo, um ditado conhecido em alemão (Liebe geht durch den Magen - que seria O amor passa pela boca) não tem 'coerência intratextual' (NORD, 2014, p. 45) em português. Uma possibilidade seria traduzir para $O$ peixe morre pela boca, mas não teria o mesmo apelo (função apelativa). Outra possibilidade seria homem se pega pela bocalestômago, mas talvez perder-se-ia a função referencial, pois particularizaria o 'amor' apenas para o homem. Para Nord (2014, p. 45), o funcionalismo não significa que o amor passa pela boca tenha necessariamente que ser substituído por o peixe morre pela boca; "funcionalidade simplesmente significa que os tradutores devem estar cientes desses aspectos e levá-los em consideração em suas decisões." 80

Tem-se que a função de uma tradução pode ser analisada sob uma perspectiva dupla: a) na relação entre o texto alvo e o público receptor e b) na relação entre o texto alvo e o texto fonte. Para sistematizar essas considerações acerca da ação translacional, Nord (2014, p. 47) elaborou uma tipologia baseada na abordagem funcionalista, que envolve "fazer uma distinção entre a função do processo de tradução e a função do texto alvo como resultado desse processo." ${ }^{81}$ Isso posto, há dois tipos de processo de tradução. O primeiro objetiva produzir, na língua alvo, um

\footnotetext{
79 "The more conventional the linguistic form, the less notice we take of it."

80 "Functionality simply means translators should be aware of these aspects and take them into consideration in their decisions."

81 “... making a distinction between the functions of the translation process and the function of the target text as the result of this process."
} 
documento de uma interação comunicativa na qual o emissor se comunica por meio de um texto fonte sob condições culturais da fonte também. $O$ segundo busca produzir na língua alvo um instrumento para uma nova interação comunicativa entre o emissor e o receptor, usando o texto fonte como modelo.

O primeiro tipo, a tradução documental, é um metatexto, cuja função comunicativa se realiza indiretamente: a tradução apela para a experiência cultural do mundo que o receptor tem. Já o segundo tipo, a tradução instrumental, é um texto em si próprio, que funciona como um texto não traduzido. A tradução instrumental pode se destinar a realizar a mesma função que o texto fonte (tradução equifuncional) ou uma função diferente do texto fonte (tradução heterofuncional). A escolha por um tipo ou outro de tradução vai determinar as decisões subsequentes do tradutor. Tais decisões se baseiam nas informações sobre: a função pretendida do texto, os receptores do texto, o provável período e local de recepção, o meio de transmissão e o motivo para produção ou recepção do texto.

Assim, segundo Nord (2005, p. 23), os princípios básicos da tradução funcional, que vem ao encontro das premissas básicas da tradução de humor e da linguagem sensível, seriam os seguintes: a) o propósito da tradução determina a escolha do método e das estratégias; b) o propósito da tradução se define na descrição da situação para a qual o texto se destina; c) o fator mais importante é a função que se deseja alcançar no texto alvo; d) a função do texto é atribuída ao texto pelo receptor no momento da recepção; e) o texto deve ter sua função facilmente reconhecível; e f) a função do texto alvo pode ser diferente da função do texto fonte, e isso não é incompatível ou contraditório.

A teoria do Escopo de Reiss e Vermeer e a teoria funcionalista desenvolvida por Nord vêm se mostrando uma grande tendência para a tradução, principalmente a audiovisual, pois foca no propósito da tradução. No entanto, transpor a barreira entre teoria e prática não é um movimento muito suave, como a própria Nord (SUOJANEN et al., 2015, p. 1) lamentou:

A orientação voltada para o receptor tem sido um aspecto particularmente sensível da teoria funcionalista e sua aplicabilidade desde o início. Os críticos perguntam como os tradutores sabem o que o público receptor espera de uma tradução. De fato, é fácil falar sobre as expectativas do público receptor, mas 
ainda mais difícil é obter evidências empíricas do que o público realmente espera. $^{82}$

Seguindo a mesma orientação funcionalista, Gregory Rabassa busca definir a tradução - e as estratégias translacionais - recorrendo a uma ideia de equivalência, muito distinta da equivalência matemática, cartesiana. Para ele, a tradução é uma operação linguística; a "língua é ligada intrinsecamente a processos mentais, vistos sob a perspectiva do indivíduo, e a processos sociais, do ponto de vista da comunidade" $" 83$ (CUÉLLAR, 2011, p. 3). Essa individualidade da língua encontra similitudes em outras línguas: a equivalência. O tradutor, então, precisa ter essa sensibilidade, esse conhecimento subjetivo, "o ouvido tradutório" ${ }^{84}$. Assim, as estratégias tradutórias de Rabassa são canalizadas nesse possível 'sexto sentido' tradutório.

Primeiramente, Rabassa afirma que a tradução deve ser feita já na primeira leitura, o que ele chamou de 'leitura cirúrgica' (surgical reading). O tradutor já faz a leitura pensando na intenção comunicativa do texto, ou o que o autor 'quer dizer'. A estratégia chamada de solução de problemas (problem solving) é uma re-leitura da Teoria do Escopo, que passa pelas seguintes etapas: identificar o problema, descrever o problema, analisar as possíveis escolhas, e apresentar a solução - assim como determinar o escopo, analisar as opções e realizar o escopo. Rabassa também aplica diversas estratégias ${ }^{85}$, sempre com o objetivo de desenvolver o 'ouvido tradutório', "sua competência para emular o efeito pretendido que a tradução provavelmente terá sobre o público alvo" "86 (CUÉLLAR, 2011, p. 4).

Um dos fatores enfocados pelas teorias funcionalistas foi uma abordagem muito mais voltada ao processo que ao produto, seja ele o texto fonte ou o texto alvo. Nesse âmbito é que entra a multidisciplinaridade, isto é, a busca por subsídios

\footnotetext{
82 "Audience orientation has been a particularly sensitive aspect of functionalist theory and applications from the start. Critics have been asking how translators know what the audience expects of a translation. Indeed, it is easy to talk about the audience's expectations but much more difficult to obtain empirical proof of what audiences really expect."

83 "...language is intrinsically linked to thought processes, seen from the perspective of the individual, and to social processes from a community viewpoint."

84 "the ear in translating", em CUÉLLAR, 2011, p.12.

${ }^{85}$ Entre as estratégias utilizadas por Gregory Rabassa, estão a estrangeirização (mantendo o texto no original), a ficcionalização (re-processamento do real sob nova ótica), e interligação semântica (transformação dos significados) que mostram a figura do tradutor como leitor ativo; ele não é controlado pela obra; ele reflete na tradução o que ocorre no encontro entre as línguas e na interação entre o texto e o leitor.

86 "....his competence to emulate the intended effect the translation is likely to have on the target audience.”
} 
em várias áreas do conhecimento para responder à pergunta postulada por Heloísa Barbosa (2007, p. 15) - "como traduzir?" - que passa pela análise do discurso, antropologia, filosofia, sociologia, lógica, psicologia cognitiva e semiótica, entre outras.

Após extensiva pesquisa sobre modelos e estratégias tradutórias, incluindo a proposta das sete 'soluções tradutórias' de Vinay e Darbelnet ${ }^{87}$, Heloísa Barbosa (2007) oferece aos profissionais da tradução uma proposta de categorização dos procedimentos técnicos da tradução, baseado no grau de divergência entre a língua fonte e a língua alvo - que ela chama de 'língua original' e 'língua da tradução'. Essa divergência, que tem como base as dificuldades apresentadas por Mounin (1963, apud BARBOSA, 2007, p. 20), se apresenta de quatro formas distintas, a saber: a) as diferenças das realidades extralinguísticas, ou seja, diferenças regionais e culturais; b) as maneiras diversas com que cada sistema linguístico vive essas realidades extralinguísticas; c) a organização morfológica ou sintática de cada sistema linguístico; e d) as dissonâncias estilísticas, ou seja, de registro e de adequação de um enunciado.

Heloísa Barbosa (2007) propõe quatro eixos de distribuição dos procedimentos técnicos da tradução. Se houver convergência do sistema linguístico, da realidade extralinguística e do estilo - situação bastante hipotética, pois até mesmo uma mesma língua pode ter realidades extralinguísticas muito diferentes, do ponto de vista estilístico e afetivo - o tradutor pode usar a tradução palavra-porpalavra e a tradução literal. O primeiro procedimento pode ser utilizado em partes do texto, e o segundo poderia funcionar "como uma pré-tradução que permitiria ao tradutor avaliar que procedimentos deverá empregar em sua tradução" (BARBOSA, 2007, p. 100).

Se houver divergência do sistema linguístico, no nível lexical, morfológico ou sintático, o tradutor se verá obrigado a lançar mão de procedimentos mais complexos como a transposição, um procedimento feito espontaneamente pelo

\footnotetext{
${ }^{87}$ A tipologia de soluções tradutórias de Vinay e Darbelnet, apresentada em 1958, inspirou muitas listas similares. As soluções apresentadas partem da 'tradução literal' no centro, como ideal; acima dela há as soluções que incorporam elementos do texto de partida - decalque e empréstimo - e abaixo estão as soluções que se aproximam mais da tradução 'oblíqua' e que apresentam mais dificuldade tradutória transposição, modulação, correspondência (equivalência) e adaptação. Segundo os autores, a zona central seria a zona mais 'segura'. Os autores também segmentaram as explicações de cada solução tradutória em três grandes seções: léxico, colocação e 'mensagem', e argumentaram a favor do tradutor não como um ator 'principal', mas cujo trabalho ainda requer um trabalho criativo intenso. (PYM, 2014, p. 7)
} 
tradutor, ao optar pelo artigo masculino ou feminino, pela desinência do singular ou do plural ao traduzir uma frase simples como the girls are beautiful. ${ }^{88} \mathrm{~A}$ complexidade dos procedimentos é diretamente proporcional à divergência maior ou menor do sistema linguístico. Assim, além da transposição, outros procedimentos incluem a modulação - que reflete a diferença das línguas na interpretação da realidade $^{89}$ - e a equivalência, que é uma substituição funcional, muito frequente em expressões idiomáticas e ditos populares ${ }^{90}$.

Quando a divergência for observada no estilo, entendido na acepção de Bally (BARBOSA, 2007, p. 96) como

os fatos de expressão da linguagem organizada do ponto de vista de seu conteúdo afetivo, isto é, expressão dos fatos da sensibilidade pela linguagem e ação dos fatos de linguagem sobre a sensibilidade.

então os procedimentos passíveis de utilização são a omissãa $o^{91}$ e seu invés, a explicitação ${ }^{92}$, assim como a compensação - ou deslocamento de um recurso estilístico - e a reconstrução - que consiste em dividir e reagrupar períodos e orações para que o segmento se torne mais interativo e iterativo, sendo que ambos procedimentos normalmente envolvem trechos maiores, e as melhorias, que são procedimentos talvez mais intuitivos e que visam a compreensão mais fluida do texto, para "não se repetirem na tradução os erros de fato ou outros tipos de erro cometidos no TLO (texto na língua original)" (BARBOSA, 2007, p. 70).

Por fim, as divergências da realidade extralinguística são geralmente as mais visíveis - pois causam divergências não só lexicais como também nos modos expressivos - e as que causam mais estranheza ao leitor/receptor. Essas divergências culturais demandam procedimentos técnicos que sirvam de ponte entre tais culturas. Entre eles está a transferência, que acontece quando o material textual original é introduzido no texto alvo, seja sob a forma de estrangeirismo - ou empréstimo, que

\footnotetext{
${ }^{88}$ As meninas são bonitas - e não 'a meninas', ou 'as meninas é', ou 'as meninas são bonita', e assim por diante.

${ }^{89}$ Como na expressão "it's raining cats and dogs", traduzida por "está chovendo pacas" (mantendo a referência a animais) ou "está chovendo canivetes".

${ }^{90}$ A tradicional resposta a um espirro, "saúde", que em inglês seria "God bless you" ou apenas "bless you”.

${ }^{91}$ Omissão de elementos que sejam desnecessários ou extremamente repetitivos na tradução, como é o caso de pronomes pessoais na tradução do inglês para o português.

${ }^{92}$ Usando o exemplo anterior, a explicitação do pronome pessoal seria imperativa na tradução do português para o inglês.
} 
sempre virá entre aspas ou em itálico - ou de transliteração - a substituição de uma convenção gráfica por outra - ou ainda a aclimatação, também chamada de decalque, que ocorre quando os empréstimos são adaptados à língua que os recebe. Há também a transferência com explicação, um esclarecimento que pode vir sob a forma de nota de rodapé ou explicação diluída no texto. Pode ainda haver a explicação sem nenhuma transferência, ou seja, a substituição do estrangeirismo sem explicitá-lo. Por último, a adaptação, que é a recriação de uma realidade extralinguística por outra equivalente na língua da tradução.

É importante ressaltar que tais procedimentos - sistematizados na figura abaixo - não estão restritos às categorias em que foram classificados; as divergências tampouco têm uma hierarquização e os eixos mencionados podem se intercalar e se mesclar, pois a ação translacional é bastante dinâmica e multifacetada. Segundo Heloísa Barbosa (2007, p 100), "a seleção dos procedimentos técnicos da tradução passaria a ser informada pela teoria das funções da linguagem, pelo tipo de texto e pela finalidade da tradução.”

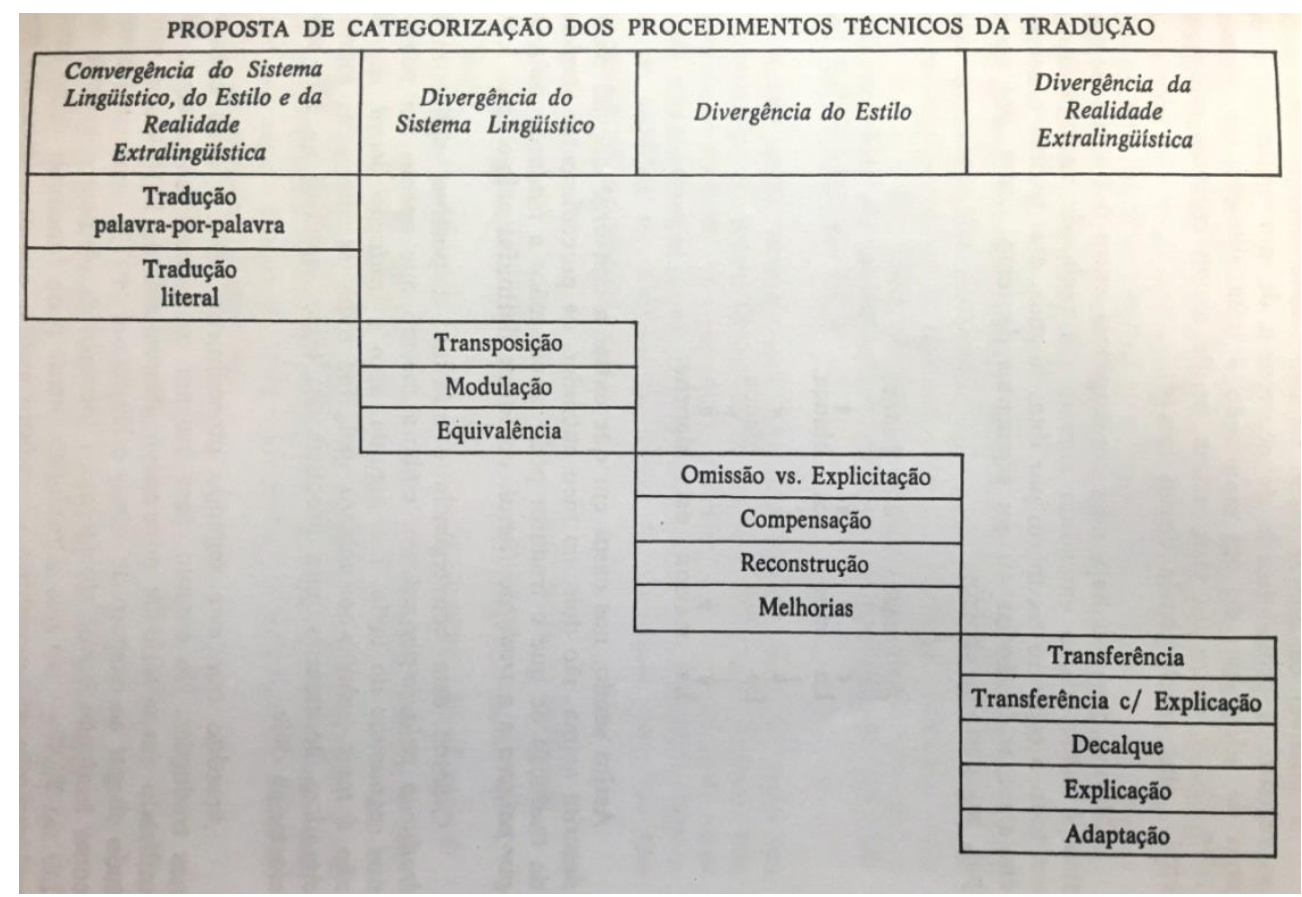

Figura 1. Proposta de categorização dos procedimentos técnicos da tradução, de Heloísa Gonçalves Barbosa. Procedimentos Técnicos da Tradução: Uma Nova Proposta. 2007. 
Os procedimentos técnicos da tradução propostos por Heloísa Barbosa se assemelham às modalidades tradutórias de Francis Henrik Aubert que pretendem ser "um modelo descritivo que meça e quantifique o grau que diferencia o texto original e sua respectiva tradução" (LEIVAS WAQUIL, 2013). Seu modelo inclui 13 modalidades: 1. Omissão: a informação não pode ser recuperada no texto meta; 2. Transcrição: "o grau zero da tradução", ou a mesma unidade sendo transferida para o texto meta, pois pertence ao repertório de ambas (como doughnut, em inglês e mais recentemente - em português); 3. Empréstimo: reprodução de um segmento no texto meta; 4. Decalque: empréstimo que sofre alterações morfológicas ou gráficas; 5. Tradução literal: para Aubert, a tradução palavra por palavra; 6. Transposição: tradução de uma unidade com mudanças morfossintáticas; 7. Explicitação/implicitação: tornar explícita ou implícita - modalidades opostas informação no texto meta; 8. Modulação: alteração ou deslocamento na estrutura semântica, com manutenção do sentido; 9. Adaptação: chamada pelo autor de 'assimilação cultural'; 10. Tradução intersemiótica: transferência de símbolos, figuras e outros para matéria textual; 11. Erro: casos de inadequação, chamados pelo autor de trocar "gato por lebre"; 12. Correção: melhora do texto fonte na produção do texto meta; e 13. Acréscimo: inclusão de segmento textual que não constava no original, sendo diferente da explicitação, no sentido de ser uma elucidação.

Como é perceptível, as estratégias/modalidades de Heloísa Barbosa e Francis Aubert, sendo ambos os modelos baseados na proposta de Vinay e Darbelnet, se assemelham bastante. As modalidades de Aubert têm a preocupação adicional de aplicar a teoria à prática, sendo a tradução literal, a transposição e a modulação as modalidades mais frequentes em suas análises. Aubert faz ainda a ressalva sobre a "possibilidade de que as modalidades apareçam sozinhas ou em conjunto em uma mesma sentença, o que chama, respectivamente, de 'estado puro' e 'forma híbrida"” (LEIVAS WAQUIL, 2013, p. 62).

Ainda que seja uma evidência muito mais implícita e subjacente que empírica, o tradutor é, também, público receptor. A orientação voltada ao leitor/receptor é uma tendência que tem na Tradução Centrada no Usuário (UserCentered Translation - UCT) uma ferramenta para operacionalizar as abordagens funcionalistas. A UCT preconiza que a "informação sobre os usuários é reunida iterativamente, durante o processo e por meio de métodos diferentes, e essa 
informação é usada para criar uma tradução utilizável"93 (SUOJANEN et al., 2015, p. 4). É interessante salientar a utilização do termo 'usuário', em vez de receptor, recipiente, ou público/leitor/espectador. Usuário foi a escolha porque, de alguma forma, o receptor/leitor vai 'usar' a tradução. Se uma tradução é vista como um meio para um fim, a leitura dela vai pode ser vista como uso.

A iteratividade se refere a um modo operacional cíclico, e no círculo interno encontram-se as estratégias de tradução, a tradução em si e a revisão. Em torno desse núcleo estão: a necessidade de tradução, onde os usuários são definidos e descritos; as especificações, ou os objetivos da tradução, assim como quando e como; os modelos mentais, que seria o momento de formação de uma visão mais clara dos usuários; e a avaliação heurística e o teste de usabilidade, que nada mais é que a revisão e reavaliação constante das estratégias tradutórias. Há ainda etapas posteriores à tradução dentro do modelo UCT: o post-mortem, que é a reflexão sobre o projeto, o processo e o produto final; e a pesquisa de recepção, cujo objeto é "descobrir como os leitores entendem o texto traduzido ou que tipos de estratégias de tradução são mais úteis e aceitáveis do ponto de vista do leitor"94 (SUOJANEN et al., 2015, p. 6), que vai resultar num feedback que, por sua vez, vai lançar luz nos conceitos de usabilidade, ou facilidade de uso, e experiência de usuário, conceito holístico que inclui emoções, preferências, crenças e percepções do usuário.

\footnotetext{
93 “....information about users is gathered iteratively throughout the process and through different methods, and this information is used to create a usable translation."

94 “... to find out how readers understand translated texts or what kinds of translation strategies are most useful and acceptable from the readers' perspective."
} 


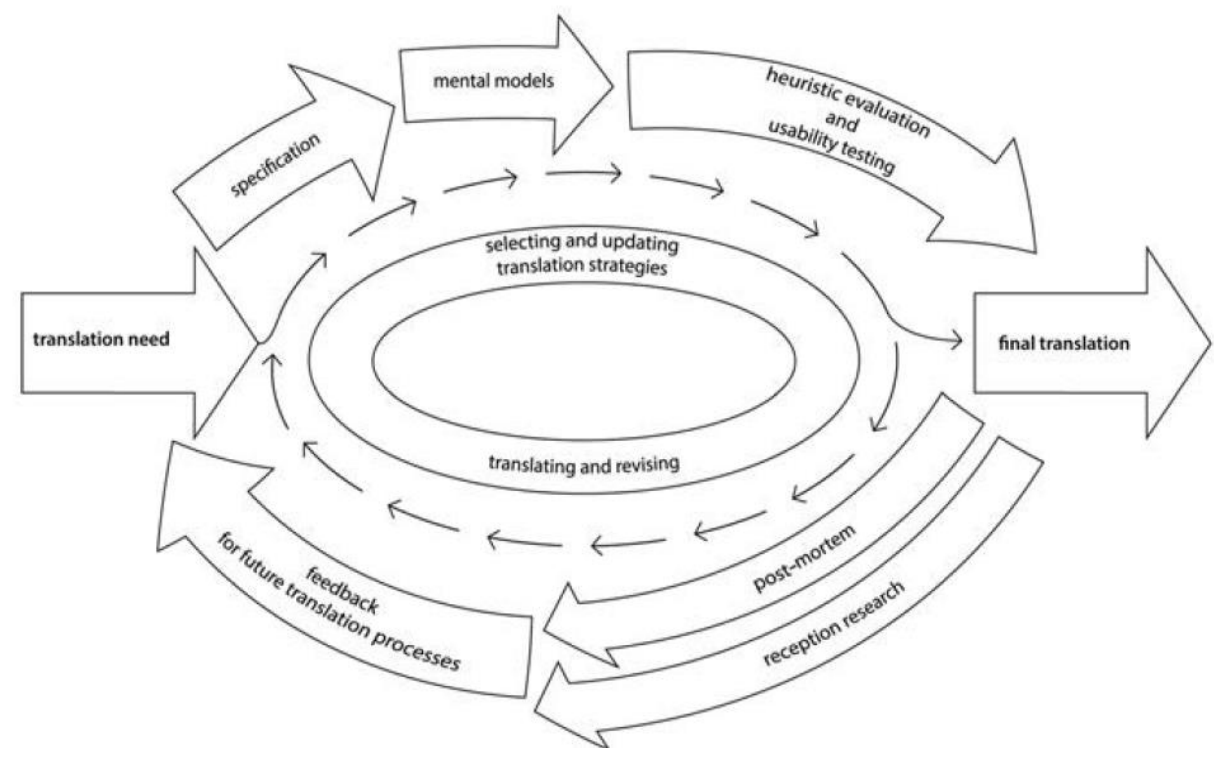

Figura 2. Processo de Tradução Centrada no Usuário.

O objetivo final é que emissor e receptor desempenhem suas funções e que essa interação "funcione". Todas as teorias e estratégias tradutórias evidenciam que a "tradução tem caráter transformador e que inevitavelmente dará origem a 'outro' texto" (MARTINS e AMORIM, 2013, p. 113). É importante lembrar que o tradutor é também o leitor que vai 'entender' o texto e dimensioná-lo a partir da determinação do escopo e da função do ato translacional.

Mais ainda, o tradutor pode explorar possibilidades criativas, já que a língua tem um papel extremamente 'produtivo' numa representação cultural, com suas forças centrífugas e centrípetas. No caso do humor, na verdade, "parece que realmente não há como fugir do fato que o humor é cercado por margens"95 (CHIARO (ed.), 2012, p. 121). Por isso a importância do conhecimento cultural e experiência para apreciar o humor, as nuances linguísticas e o impacto da distância emocional, uma vez que culturas diferentes vão ver e apreciar de forma distinta a manifestação do humor e de linguagem sensível.

A recente ferramenta UCT encontrou nas teorias funcionalistas seu melhor meio de expressão. É um modelo de utilização que preconiza a ergonomia cognitiva, ou seja, como os processos mentais - como percepção, memória, raciocínio e resposta motora - podem afetar a usabilidade dos textos, além de sua habilidade de suscitar e manter o interesse do leitor. Uma das estratégias usadas nessa 'ginástica

\footnotetext{
95 "It would appear that there is indeed no escaping the fact that humor is surrounded by borders."
} 
cognitiva' é a explicitação, que acontece quando "aspectos gramaticais, semânticos ou pragmáticos que estão implícitos ou pressupostos no texto fonte são explicitados na tradução"96 (SUOJANEN et al., 2015, p. 55). A explicitação é uma das estratégias mais eficazes para a UCT; além dela, outras estratégias de adaptação pragmáticas relevantes para a tradução voltada para o usuário são: adições, que não deixam de ser explicitações, mas são também outros tipos de acréscimos explicativos ou suplementares; omissões, que são exclusões de material desnecessário ou óbvio, além de elementos tabu; substituições, que pode ser trocar uma alusão estranha por uma mais familiar; e rearranjos textuais, na estrutura ou formulação sintática.

Tais estratégias vão ao encontro da intenção de uma experiência mais positiva para o usuário da tradução, ou ao menos o construto do usuário pretendido, um modelo do futuro usuário da tradução e de suas futuras reações. Segundo Mossop (2007, apud SUOJANEN et al, 2015, p. 65):

\begin{abstract}
A reação do leitor à tradução pode ser considerada sob dois pontos de vista: do ponto de vista da recepção, há a reação real do leitor; do ponto de vista da produção, há a reação imaginada na mente do tradutor. É a reação imaginada que será a questão aqui. ${ }^{97}$
\end{abstract}

Para a Tradução Centrada no Usuário, o leitor não é apenas um receptor de infomação, mas um usuário, que tem função de decodificador, de profissional, de criador de significado. Nesse sentido, escritor e leitor estão unidos numa espécie de parceria; o leitor tem "papel central na determinação do significado de um texto. Nem o escritor e nem o texto tem controle ou criam significado: eles só dão ao leitor uma oportunidade de interpretação independente"98 (SUOJANEN et al., 2015, p. $67)$.

O processo de tradução é intricado e envolve grande variedade de modelos, estratégias e perspectivas, todos se subvertendo ou se re-integrando, sempre com a intenção de interatividade. Como colocado por Venuti (apud SUOJANEN et al., 2015, p. 42):

\footnotetext{
96 “...grammatical, semantic or pragmatic aspects that are implicit or presupposed in the source text are made explicit in the translation."

97 "Reader reaction to translation can be considered from two points of view: from the point of view of reception, there is the actual reaction of the reader; from the point of view of production, there is the reaction imagined in the mind of the translator. It is the imagined reaction which will be of concern here." 98 "....central role in determining the meaning of a text. Neither the writer nor the text can control or even create the meaning; they only provide the readers with an opportunity for an independent interpretation."
} 
O leitor deve aprender novas maneiras de pensar e a tradução deve abrir novos caminhos de interpretação: a tradução que inicia um evento introduz uma diferença linguística e cultural, iniciando novas maneiras de pensar inspiradas na interpretação do texto fonte. ${ }^{99}$

\title{
1.4.Legendagem - Tempos Modernos ${ }^{100}$
}

\author{
Subtitles offer a way \\ into worlds outside of ourselves. ${ }^{101}$ \\ Atom Egoyan e Ian Balfour
}

A legendagem pode ser definida como uma prática tradutória que consiste em

apresentar um texto escrito, geralmente na parte inferior da tela, que tenta recontar o diálogo original dos falantes, assim como os elementos discursivos que aparecem na imagem (letras, inserções, pichações, inscrições, cartazes, e outros), e a informação contida na trilha sonora (músicas, vozes em off) ${ }^{102}$ (DÍAZ-CINTAS e REMAEL, 2007, p. 8)

Em termos técnicos, a legendagem está constrita a determinados aspectos que limitam sua abrangência espaço-temporal; tal descrição será feita na próxima sessão. Em termos linguísticos, a legendagem também obedece a certos parâmetros que diferem um pouco dos critérios técnicos de legendagem, pois restringe as funções extralinguísticas (classe social, gênero, idade) e paralinguísticas (gestos, movimentos, expressões faciais). Essa natureza complexa determina restrições. Segundo Panek (2009, p. 14),

A legendagem como processo artístico de tradução é limitado por restrições formais (quantitativas), que surgem do fato que as legendas devem se integrar

\footnotetext{
99 "The reader is to learn new ways of thinking and the translation is to open up new interpretative avenues: The translation that sets going an event introduces a linguistic and cultural difference in the institution, initiating new ways of thinking inspired by an interpretation of the source text."

${ }^{100}$ Tempos modernos (Modern times) é um filme de 1938 sobre um operário (Charles Chaplin) de uma linha de montagem que testou uma "máquina revolucionária" para evitar a hora do almoço, e é levado à loucura pela "monotonia frenética" do seu trabalho. Após um longo período em um sanatório, ele fica curado de sua crise nervosa, mas desempregado. Ele deixa o hospital para começar sua nova vida, mas encontra uma crise generalizada e equivocadamente é preso como um agitador comunista, que liderava uma marcha de operários em protesto. Simultaneamente, uma jovem rouba comida para salvar suas irmãs famintas, que ainda são muito novas. Elas não têm mãe e o pai está desempregado, mas o pior ainda está por vir, pois ele é morto em um conflito. A lei vai cuidar das órfãs, mas enquanto as menores são levadas, a jovem consegue escapar.

${ }^{101}$ Legendas mostram um caminho para mundos fora de nós.

102 “...presenting a written text, generally on the lower part of the screen, that endeavours to recount the original dialogue of the speakers, as well as the discursive elements that appear in the image (letters, inserts, graffiti, inscriptions, placards, and the like), and the information that is contained on the soundtrack (songs, voices off)."
} 
aos canais comunicativos que as acompanham (texto, imagem e som) e a habilidade e velocidade de leitura do espectador. [...] Além disso, a legendagem envolve restrições textuais (qualitativas) que se referem à língua, ao estilo, ao público alvo e às diferenças culturais. ${ }^{103}$

Ou seja, "a legendagem estabelece, a priori, uma relação de conflito com a totalidade do produto" (GOROVITZ, 2006, p. 22), pois é um acréscimo à totalidade do filme. Programas legendados apresentam três componentes: a palavra, a imagem, e as legendas, numa combinação de fatores visuais e sonoros que transmitem uma mensagem. Cabe aqui uma individuação; Liberatti (2011, p. 220) estabeleceu uma distinção entre legendagem - a gravação de legendas no filme, o tempo de aparição, tamanho da letra, ou seja, aspectos técnicos - e legendação, que se refere ao trabalho intelectual do tradutor, aos procedimentos utilizados para a tradução de um texto. Assim como na tradução de textos, a legendação também pode ser subdividida em: a) legendação intralingual, ou vertical, destinada a deficientes auditivos; e b) legendação interlingual, ou diagonal, feita a partir de uma língua falada para outra na forma escrita. Ainda que distintas, ambas ocorrem no mesmo contexto audiovisual, envolvem conversão da língua falada para texto escrito e exigem redução da quantidade de diálogo para obedecer as regras técnicas exigidas.

Como se observa na figura abaixo, o processo de legendação é um processo diagonal de tradução diassemiótica que 'atravessa' da fala na língua fonte para o texto escrito na língua alvo. Então, a legendação pode ser definida como "uma tradução diassemiótica na mídia polissemiótica (incluindo filmes, TV, vídeo e DVD), na forma de texto escrito apresentado na tela em sincronia com o diálogo

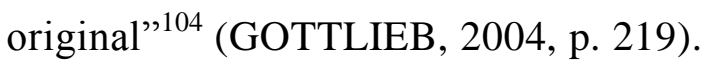

\footnotetext{
103 "Subtitling as an artistic translation process is constrained by formal (quantitative) constraints which arise from the fact that subtitles should be integrated with the accompanying communicative channels (text, image and sound) and the receiver's reading speed ability. [...] Additionally, subtitling involves textual (qualitative) restrictions that refer to the language, the style, the target audience and cultural differences."

104 "Subtitling can be defined as diasemiotic translation in polysemiotic media (including films, TV, video and DVD), in the form of one or more lines of written text presented on the screen in sync with the original dialogue."
} 


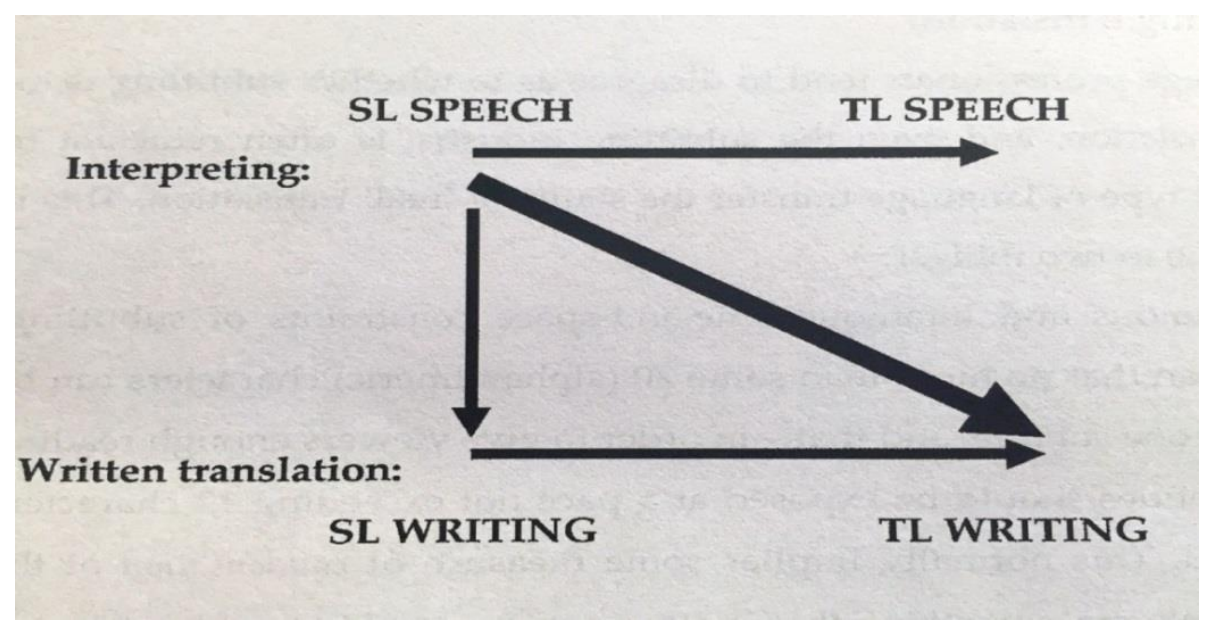

Figura 3. Tradução diagonal. (GOTTLIEB, 2004)

Segundo Branco (2013, p. 110), em algumas cenas, tanto cenário quanto expressões faciais dos personagens podem ser mais importantes que a fala, e o espectador, mesmo inconscientemente, está realizando uma tradução intersemiótica. A fala é repleta de inflexões e variações que não são transportadas ao texto escrito; essa é uma prerrogativa do espectador, pois a legendagem, "apropriada no fenômeno geral de recepção da mensagem, oferece pontos de partida que sustentam o ato de reconstrução da mensagem pelo espectador" (GOROVITZ, 2006, p. 46). Em última instância, é o espectador que vai reconstruir a mensagem com base na combinação de fatores a que é exposto, o que vai ao encontro dos princípios da tradução funcional e da tradução centrada no usuário. Como em outros textos - além dos humorísticos e os que contêm linguagem sensível -, os critérios de usabilidade das legendas são atrelados à cultura e à língua, pois, segundo Gorovitz (2006, p. 66),

É evidente que o tradutor deve facilitar ao máximo a atividade do espectador, restringindo a utilização da pontuação, estabelecendo boas conexões (quebras coerentes adequadas à imagem), omitindo, sintetizando, utilizando preferencialmente palavras menores, optando por palavras mais expressivas e estéticas, variando o tamanho da mensagem, evitando estruturas complexas, cacofonias visuais, variando as estruturas sintáticas e os estilos, etc.

Levando todas essas considerações para o universo da legendagem/legendação, poder-se-ia afirmar que a tradução para a legendagem, seja para textos humorísticos, irônicos, sensíveis ou não, pode buscar nas teorias de tradução funcionais a resposta para encontrar o canal de comunicação entre texto e espectador. A mensagem audiovisual é a soma do som com a imagem. Se alguma coisa passa despercebida, a comunicação foi falha; é preciso uma interação inventiva 
e criativa, já que um texto pode ter tantas leituras quanto leitores houver. Ridd (apud FERREIRA, GOLDNADEL e KRAUSPENHAR, 2007, p. 8) afirma que o legendador deve levar em conta que a legenda "não é uma tradução convencional, mas um auxílio comunicativo ao espectador que não domina a língua original do filme." Assim, as legendas precisam ter unidade semântica e contribuir para o filme, para "compensar o esforço do espectador" de ler a legenda ao mesmo tempo em que observa as imagens na tela.

Em relação à legendagem/legendação de humor e de linguagem sensível, Yau Wai-Ping (CHIARO, 2012, p. 119) coloca,

Diálogos legendados ou dublados não só expressam humor audiovisual do texto fonte, mas também emitem uma mensagem lateral sobre a identidade cultural e relações de poder do público alvo. ${ }^{105}$

A combinação simultânea dos fatores visuais e sonoros é que vai permitir que o espectador [re]crie a mensagem, com todos os aspectos envolvidos. Tal mensagem encerra também a percepção de gestos, entonações e ritmos que compensam as 'ausências' nos diálogos legendados. A mensagem contida nas legendas, com todas as manifestações culturais e extralinguísticas que a envolvem, passa por um processo de reconhecimento e familiarização que permite que o espectador construa uma mensagem efetiva e afetiva da mensagem pretendida. De acordo com Gorovitz (2006, p. 20),

o texto sofre uma reformulação na qual os elementos são rearticulados, como que dublados virtualmente pelo espectador, que colore os espaços brancos da tela [...], palco para a encenação de mitos e símbolos presentes e atuantes na sociedade.

Pedersen também aborda os aspectos culturais da legendagem/legendação, tanto no que diz respeito às expressões culturais intralinguísticas quanto as extralinguísticas. Por referências culturais extralinguísticas (ECR, sigla em inglês extralinguistic culture-bound references), ele entende os itens culturais que não fazem parte do sistema de linguagem, ainda que ele mesmo contra-argumente

\footnotetext{
105 "Subtitles and dubbed dialogue not only convey audiovisual humor of the source text but also emit a lateral message about the cultural identity and power relations of the target audience."
} 
dizendo que, "dependendo do ponto de vista, tudo, algumas coisas, ou nada é puramente intralinguístico"106 (PEDERSEN, 2005, p. 2).

Para traduzir, ou 'transportar', elementos culturais, para a legenda, Pedersen (2005) utiliza diversas estratégias. Em primeiro lugar, ele singulariza o equivalente oficial, ou seja, um processo meramente burocrático que obedece um padrão já estabelecido $^{107}$. A partir daí, Pedersen passa por uma longa lista de estratégias que vão se aproximar mais da língua fonte ou da língua alvo (ou, como ele coloca, texto fonte e texto alvo). As estratégias mais voltadas ao texto fonte são: retenção, que permite que o elemento da língua fonte 'entre' no texto alvo, especificação, que acrescenta informação não presente no texto fonte; explicitação, que é uma expansão de material que está latente no texto fonte, como uma abreviatura, por exemplo; adição, que acrescenta material que na cultura do texto fonte não precisa de explicação ${ }^{108}$; e tradução direta, onde nada é acrescentado ou subtraído, com suas subcategorias - decalque e deslocamento ${ }^{109}$. Já se aproximando mais da língua alvo, as estratégias são: generalização, que é a substituição de algo específico para algo mais geral; substituição, seja cultural - onde a referência cultural fonte é removida seja por meio de paráfrase, que é reformular a referência cultural; e omissão, que é a eliminação do elemento cultural.

A título de complementação, a figura abaixo mostra as estratégias esmiuçadas por Pedersen para a legendagem/legendação. "Isso não significa que, necessariamente, os legendadores estejam cientes das escolhas que fazem, já que parte do processo pode estar internalizado ou subconsciente" ${ }^{110}$ (PEDERSEN, 2005, p. 9). Isso ocorre principalmente quando mais de uma estratégia é utilizada. Os parâmetros que influenciam a decisão por qual estratégia utilizar são: transculturalidade, ou como as culturas estão interconectadas e emaranhadas atualmente; extratextualidade, ou a existência ou não de um referente cultural fora do texto fonte; centralidade da referência, que fará a escolha pender entre estratégias de retenção ou omissão; redundância intersemiótica, que implica economia nas legendas, evitando repetições; co-texto, que evita repetições no diálogo; restrições

\footnotetext{
106 “...depending on your standpoint, everything, some things, or nothing is purely intralinguistic."

${ }^{107}$ Como, por exemplo, traduzir Donald Duck por Pato Donald.

${ }^{108}$ A explicitação e a adição são modos de especificação.

${ }^{109}$ Decalque seria um 'empréstimo linguístico' que considera mais a forma que a ideia, como 'cartão postal' ou 'arranha-céu'; o deslocamento se aproxima do texto alvo.

110 "It does not necessarily mean that the subtitlers themselves are consciously aware of what choices they make, as part of the process may be internalized and subconscious."
} 
específicas da mídia, que determinam os limites das legendas; e considerações paratextuais, que são os parâmetros relacionados ao filme - gênero, normas do cliente, prazos, etc.

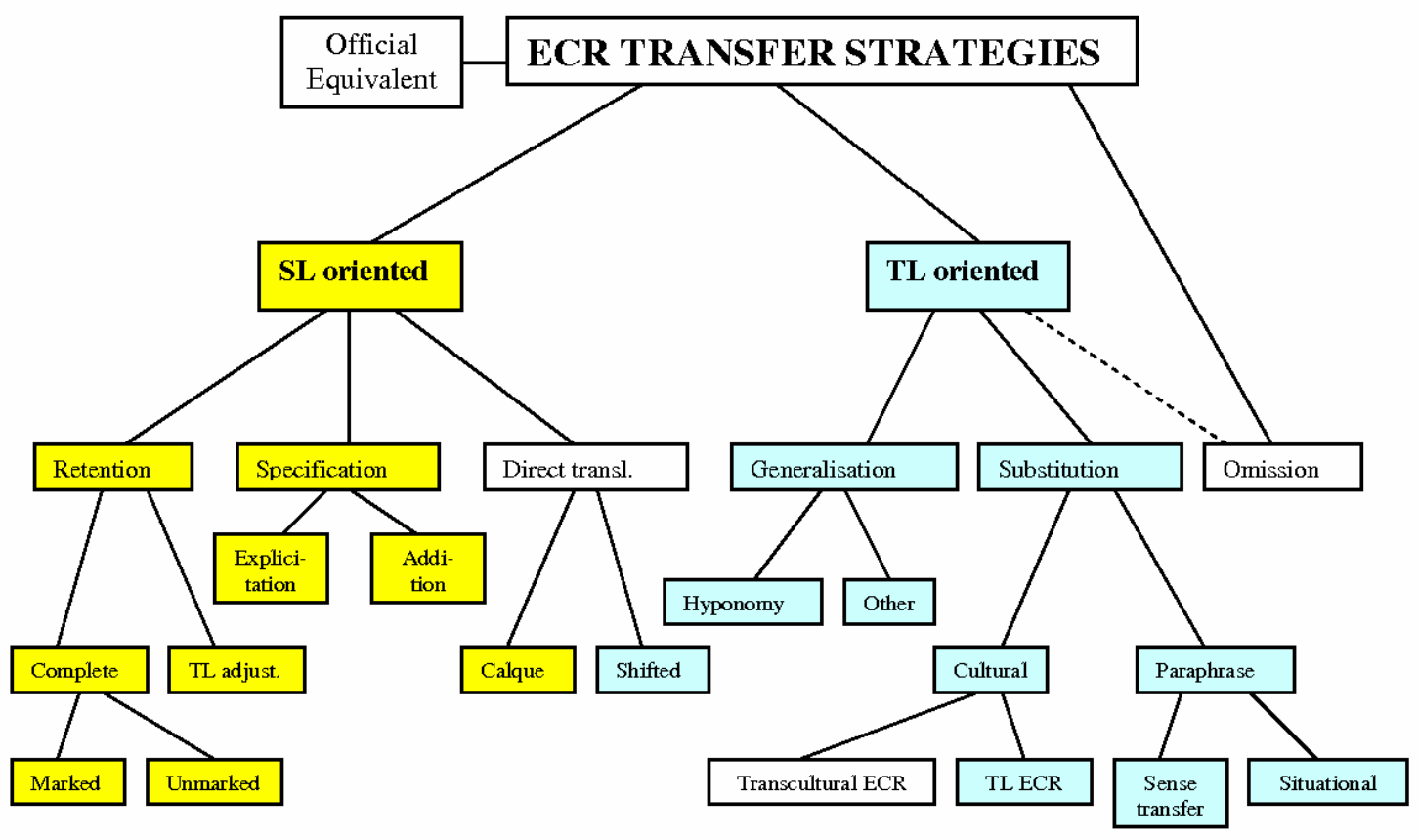

Figura 4. Estratégias de tradução para legendagem de elementos culturais extralinguísticos.

Traduzir, pois, é uma "atividade humana realizada através de estratégias mentais empregadas na tarefa de transferir significados de um código linguístico para outro" (BARBOSA, 2007, p. 21). Traduzir humor e linguagem sensível é "qualitativamente diferente de qualquer outro tipo de tradução" (LIBERATTI, 2011, p. 219). Traduzir para a legendagem "não consiste apenas na tradução do texto, mas também nas imagens do mesmo" (MARTINS e AMORIM, 2013, p. 109). Por isso, o tradutor, como receptor e emissor do conteúdo do filme,

negocia significados e sentidos não mais apenas com o texto original e com o construto mental que corresponde à sua visão do autor original do texto, mas com outro construto mental, o de sua visão, unitária ou multifacetada, do conjunto de receptores da tradução que empreenderá do texto. (AUBERT, 1994, apud GOROVITZ, 2006, p. 47) 


\title{
Considerações técnicas da legendagem
}

Em termos técnicos, a legendagem seria, de acordo com Georgakopoulou (2006, apud DÍAZ-CINTAS e ANDERSON, 2009, p. 21),

\begin{abstract}
...traduções escritas do diálogo original condensadas, que aparecem como linhas de texto, geralmente posicionadas no pé da tela. As legendas aparecem e desaparecem para coincidir temporalmente com a porção correspondente do diálogo original e são quase sempre adicionadas à imagem na tela numa data posterior, como atividade pós-produção. ${ }^{11}$
\end{abstract}

As principais restrições para a legendagem, do ponto de vista técnico, são espaciais e temporais, e afetam diretamente o formato das legendas. Sabe-se que há dois tipos de informação para o espectador: a ação na tela, e a tradução dos diálogos. Para que o texto legendado seja eficaz, segundo Georgakopoulou (apud DÍAZCINTAS e ANDERSON, 2009, p. 21), ele precisa "preservar a sequência de atos da fala [...] de forma a refazer a dinâmica da comunicação." ${ }^{112}$ Quando o aspecto visual for essencial para a compreensão da cena, as legendas deveriam mostrar só o estritamente necessário; se, ao contrário, a informação crucial estiver no que é dito, as legendas deveriam ser mais completas. A facilidade de leitura - legibilidade depende muito de como as palavras estão organizadas na tela. Aqui a referência é não somente dependente da organização espacial na tela, mas também do uso da gramática e da estrutura sintática.

A legendagem é uma forma de tradução complexa e única. Gottlieb (1992, apud PANEK, 2009, p. 11) menciona que a legendagem possui os seguintes componentes: se apresenta na forma escrita; é aditiva, ou seja, é suplementar ao original; é imediata, não se pode voltar ou ir mais a frente; é síncrona, pois o original e a tradução são percebidos ao mesmo tempo; e é polimidiática, pois há mais de um canal comunicando a mensagem. Obviamente, tem seus prós e contras; as legendas tomam espaço da tela e, mesmo que o espectador não queira ler, seus olhos são involuntariamente atraídos para o ‘intruso’ da tela. Por outro lado, é a

\footnotetext{
111 “...condensed written translations of original dialogue which appear as lines of text, usually positioned towards the foot of the screen. Subtitles appear and disappear to coincide in time with the corresponding portion of the original dialogue and are almost always added to the screen image at a later date as a postproduction activity."

112 "... to preserve the sequence of speech acts $[\ldots]$ in such a way as to relay the dynamics of communication".
} 
única forma de tradução audiovisual que permite o contato com a língua original, possibilitando perceber nuances extralinguísticas.

O espaço da legenda não permite longas explicações. A regra geral é que haja apenas duas linhas de legendas, sendo o número de caracteres em cada linha dependente do meio em que a legenda é veiculada; no máximo 35 caracteres por linha no caso da televisão, chegando até 40 no cinema. Mais do que isso, segundo Karamitroglou (1998) seria contraproducente, pois haveria a necessidade de diminuir o tamanho da fonte, afetando a legibilidade. A posição ideal na tela seria na parte central inferior, que geralmente não influencia a apreciação estética do filme; as legendas não podem tomar mais que $20 \%$ do espaço da tela. Além disso, os caracteres não-serifados ${ }^{113}$ são preferíveis. A centralização das legendas facilita a leitura, já que a maior parte da ação visual ocorre no centro da tela. Por fim, a cor de preferência deve ser o branco pálido, pois cores fortes podem ser cansativas para o espectador. Também devem preferencialmente estar numa caixa ("ghost-box") cinza transparente - em vez de caracteres com contornos - pois "foi provado que é mais fácil ler com um fundo fixo que num fundo variável"114 (KARAMITROGLOU, 1998).

A velocidade de leitura de um adulto ${ }^{115}$ é, em geral, de 150 a 180 palavras por minuto; esse é um parâmetro que deve ser respeitado na legendagem, e significa que um máximo de duas linhas de 35 caracteres cada deveria ficar na tela por 6 segundos, já contando o tempo de 'gatilho', isto é, o tempo que o cérebro demora para iniciar a leitura. Em contrapartida, o tempo mínimo de uma legenda na tela é de 1 segundo e meio; menos do que isso, a legenda passaria despercebida. No entanto, se tal legenda - de apenas uma ou duas palavras - ficar na tela por mais que 1 segundo e meio, o espectador fará a 're-leitura', o que é negativo para a compreensão do filme, por ser tempo 'tirado' da ação visual. Além disso, há um intervalo de 1/4 de segundo para a entrada da legenda após o início da fala; é o tempo

\footnotetext{
${ }^{113}$ Em tipografia, as serifas são os pequenos traços e prolongamentos que ocorrem no fim das hastes das letras. Tradicionalmente, os textos serifados são utilizados em blocos longos, enquanto textos sem serifa são utilizados em textos mais curtos. No caso das legendas, os tipos ARIAL e HELVETICA são os mais utilizados.

114 “...it has been proven that it is easier for the eye to read against a fixed rather than a varying/moving background."

${ }^{115}$ Uma média feita entre espectadores com idades variando entre 14 e 65 anos; a velocidade de leitura de crianças entre 6 e 14 anos é de 90-120 palavras por minuto, o que influencia o cálculo da duração das legendas na tela.
} 
do cérebro processar a informação e começar a ler. O mesmo acontece na saída: a legenda não pode ficar mais de 2 segundos na tela após o fim da fala. Por fim, 1/4 de segundo deve ser deixado entre legendas.

Com relação à pontuação, há padrões diferenciados para cada empresa responsável pela legendagem. Em geral, Karamitroglou (1998) sustenta que reticências devem ser usadas para indicar que uma fala continuará na próxima legenda; da mesma forma, os pontos devem ser também colocados no início da fala seguinte, demonstrando que é a continuação do que foi dito. Se a escolha for pela eliminação dessas reticências, a frase seguinte deve iniciar com letra minúscula. Travessões devem ser colocados no início de cada frase de um diálogo, caso haja duas frases na mesma legenda; caso contrário, o travessão é desnecessário. Os outros símbolos de pontuação - vírgulas, dois pontos, ponto e vírgula, aspas, parênteses, colchetes - devem ser usados como em material impresso. Parênteses para comentários ou explicações podem ser usados, desde que não ultrapassem o tempo alocado à legenda.

A divisão de linhas deve obedecer ao máximo às regras gramaticais e sintáticas da língua alvo. Como regra geral, não se deve separar o artigo do substantivo ou segmentar uma locução. Por exemplo, a frase: 'A separação daqueles dois parecia inevitável' deveria ser separada numa legenda assim:

A separação daqueles dois

parecia inevitável.

Ou talvez assim:

A separação

daqueles dois parecia inevitável.

No entanto, não seria de leitura fácil ou agradável as opções:

A separação daqueles

dois parecia inevitável.

A separação daqueles dois parecia

inevitável. 
Das opções mais 'legíveis', a segunda seria ainda mais aconselhável, pois a sequência mais longa de caracteres é a inferior, tornando ainda mais confortável a leitura e deixando mais espaço para as informações visuais. O tamanho ideal seria o de duas linhas com o mesmo número de caracteres, pois o espectador, de maneira geral, sempre lê material nesse formato; caso isso seja impossível, deve-se tentar colocar mais informação na linha inferior. Deve haver uma consonância entre sintaxe e geometria. "No entanto, se tivermos que sacrificar alguma, deveríamos sacrificar a geometria"116 (KARAMITROGLOU, 1998).

Diante de tais limitações ou restrições, é necessário ajustar a mensagem da forma mais adequada possível, já que, segundo Martins e Amorim (2013, p. 108), “a dificuldade é o fato de que é quase impossível lermos na mesma frequência de velocidade na qual escutamos." Por isso, as estratégias tradutórias para a legendagem buscam omitir certos elementos que são comuns à fala, como repetições, vocativos, construções gramaticalmente inaceitáveis, lapsos, contradições, correções, palavras conhecidas internacionalmente ou óbvias - como sim, não, ok -, expressões de afirmação, negação, surpresa ou polidez que são acompanhadas por gestual, interjeições, e palavras de preenchimento. ${ }^{117}$

Tais estratégias, obviamente, são semelhantes às estratégias tradutórias já mencionadas aqui; a particularidade é que elas têm que se adaptar ao espaço restrito da legenda e aos canais semióticos do meio audiovisual: a imagem, o texto, os efeitos sonoros e a fala. Mais acima foram apresentadas as estratégias tradutórias de acordo com Barbosa (2007) e Pedersen (2005). Gottlieb (2005) também propôs uma série de estratégias para legendagem que são particularizadas e estudadas dentro desse universo específico. São elas: a transferência, em que toda a mensagem é transmitida fielmente; a imitação, em que se preserva a forma original; a transcrição, que preserva as peculiaridades e até irregularidades da língua fonte; a expansão, que adiciona informações complementares para tornar a mensagem mais compreensível (não muito utilizada devido à limitação espaço-temporal); a paráfrase, que altera a mensagem para dar uma forma mais fidedigna na língua alvo;

\footnotetext{
116 "However, if we had to sacrifice the one for the sake of the other, we should prefer to sacrifice geometry."

${ }^{117}$ Conhecidas em inglês como 'padding', quase sempre vazias de significação, são apenas palavras que preenchem lacunas no discurso, como "hum", "veja bem", "sabe”, e outras.
} 
o deslocamento, que muda uma mensagem de maneira a produzir o mesmo efeito no espectador; a condensação, que reduz a mensagem sem perder o conteúdo; a supressão, que exclui deliberadamente parte da mensagem, principalmente a que não tem conteúdo, como visto acima (expressões de surpresa, negação); o extermínio, que é a redução extensa de partes importantes da mensagem; e a renúncia, que é a não tradução.

Como visto anteriormente, há uma transferência diagonal na legendagem; é uma tradução diassemiótica, pois aparece como uma interação entre vários sistemas de significação e há o envolvimento de diferentes canais. Isso faz com que as legendas sejam facilmente percebidas e objeto de crítica ao mesmo tempo. Além disso, tem um caráter efêmero, segundo Martinez (2007):

não há replay, portanto, se o espectador não assimila o texto da legenda naqueles dois ou três segundos em que permanece na tela, sua compreensão do conteúdo geral do programa fica prejudicada.

$\mathrm{Na}$ tradução diagonal, traduz-se do código oral, mais livre, para o código escrito, mais rígido. É uma operação/ação translacional que envolve a complexa interação entre seus componentes principais, a palavra falada, a imagem e a legenda; isso impõe um notável encargo ao legendador que, segundo Gottlieb (2004, p. 222),

Além de ser um excelente tradutor, um bom legendador precisa ter o ouvido musical de um intérprete, o discernimento de um editor de notícias, e o senso de estética de um designer. Além disso, [...] o legendador também deve ter a mão firme de um cirurgião e o timing de um percussionista. ${ }^{118}$

\footnotetext{
118 "Apart from being an excellent translator, a good subtitler needs the musical ears of an interpreter, the no-nonsense judgement of a news editor, and a designer's sense of esthetics. In addition, [...] the subtitler must also have the steady hand of a surgeon and the timing of a percussionist."
} 


\section{METODOLOGIA - Mentes Perigosas ${ }^{119}$}

Este estudo está dividido em duas partes distintas: uma visão teórica da tradução do humor e da linguagem sensível em comédias brasileiras, das técnicas de legendagem e das estratégias da legendagem de humor, com análise descritiva da literatura sobre os temas abordados; e um estudo de caso sobre as instâncias de humor e linguagem sensível nas legendas em inglês de comédias brasileiras, de diversas épocas da cinematografia brasileira, com vistas a determinar pontos de estranhamento, verificar as soluções apresentadas, e analisar e comentar tais soluções, apresentando possíveis alternativas.

O estudo de caso é, segundo o sociólogo Robert K. Yin, "a estratégia de preferência quando as perguntas a serem respondidas são 'como' e 'por que', quando o investigador não tem controle sobre os eventos, e quando o foco está num fenômeno contemporâneo em um contexto real." (SARAJEVA, 2009) ${ }^{120}$ O estudo de caso é flexível e examina os eventos com maior profundidade, analisando o contexto e enfocando a análise detalhada do todo.

Há um conceito estereotipado do método de estudo de caso, de "parente pobre" entre os métodos de ciência social (YIN, 2001), um esforço de pesquisa menos desejável; talvez a inquietação se deva ao fato de estudos de caso fazerem uma análise “generalizante” e não "particularizante”. Segundo Schramm (1971, apud YIN, 2001), “a essência de um estudo de caso (...) é que ela tenta esclarecer uma decisão ou um conjunto de decisões: o motivo pelo qual foram tomadas, como foram implementadas e com quais resultados."

O estudo de caso é uma investigação empírica que se beneficia de suposições teóricas para conduzir a coleta e análise de dados; é, portanto, uma estratégia de

\footnotetext{
${ }^{119}$ Mentes perigosas (Dangerous minds) é um filme de 1995 que conta a história de uma ex-oficial da marinha que abandona a vida militar para ser professora de inglês. Só que logo na primeira escola que começa a lecionar ela vai se deparar com diversas barreiras. Sendo um colégio de negros, latinos e na maioria de pessoas pobres, ela terá que lidar com a rebeldia dos alunos. Como a professora Louanne Johnson (Michelle Pfeiffer) não consegue através de métodos convencionais a atenção da sua turma, ela parte para outra forma de ensino. Passa a dar aulas com caratê e músicas de Bob Dylan, tentando ajudar a turma através de métodos pouco convencionais.

120 "[...] the preferred strategy when 'how' and 'why' questions are being posed, when the investigator has little control over events, and when the focus is on a contemporary phenomenon within some real-life context."
} 
pesquisa exploratória natural e prática que questiona “a) o que será explorado; b) o propósito da exploração; c) os critérios através dos quais se julgará a exploração como bem-sucedida." (YIN, 2001). 


\section{ANÁLISE DOS FILMES - A Última Sessão de Cinema ${ }^{121}$}

A tarefa do tradutor é libertar na própria língua aquela língua pura, que está exilada na estrangeira; libertar na transpoetização aquela língua que está cativa na obra.

Walter Benjamin

Cada espectador vai 'ver' um filme de uma maneira distinta, assim como cada leitor 'lê' um livro de maneira diferente; não vemos o mundo como ele é, mas como nós somos. Do ponto de vista do leitor ou espectador, um livro ou um filme é uma obra acabada; do ponto de vista do tradutor/legendador, o mesmo livro ou filme é um projeto, no qual ele atua como receptor e emissor. Tal processo de recepção é um encadeamento de efeitos, criações e recriações; "o receptor do filme estrangeiro, isolado do sentido dos diálogos, tem a ele um acesso intermediado" (GOROVITZ, 2006, p. 23). $\mathrm{O}$ acesso e a significação da mensagem se fazem a partir de associações em que o espectador "familiariza o desconhecido e reconhece os elementos familiares em processos de identificação e distanciamento que realizam a apropriação da mensagem" (id., 2006, p. 23).

No caso de filmes estrangeiros legendados, o espectador reconhece as mensagens por meio das legendas e dos elementos que estão disponíveis, como a tonalidade do diálogo, os toques de humor e ironia, e outras funções que não aparecem na tradução escrita. No ato de recepção,

esse espectador reconstrói o diálogo a partir de um misto de situações que fazem parte da sua vivência e de progressivas familiarizações, restaurando as inadequações e as carências da mensagem legendada. (GOROVITZ, 2006, p. 24)

A análise que se segue vai examinar as estratégias tradutórias dos filmes selecionados, sob a luz das abordagens funcionalistas de Reiss e Vermeer e Nord, dos modelos de tradução de Heloisa Barbosa e das estratégias tradutórias propostas

\footnotetext{
${ }^{121}$ A última sessão de cinema (The last picture show) é um filme de 1971, com o seguinte enredo: entre a $2^{a}$ Guerra Mundial e a Guerra da Coreia, dois jovens, Duane Jackson (Jeff Bridges) e Sonny Crawford (Timothy Bottoms), vivem em Anarene, uma pequena cidade do Texas. Eles se parecem fisicamente, mas mentalmente e emocionalmente são opostos. Passam boa parte do tempo no cinema ou no salão de sinuca. Enquanto Duane tenta se firmar frequentando festas de embalo, Sonny é iniciado no sexo por Ruth Popper (Cloris Leachman), a frustrada esposa do seu treinador. Mas os dois compartilham um desejo: Jacy (Cybill Shpeherd).
} 
por Pedersen e Gottlieb. As considerações técnicas serão feitas a cada análise, pois as legendas seguem padrões diferentes.

Legendas não são um trabalho independente, ou mesmo um texto independente. São parte de uma entidade textual multimodal maior, e são uma ajuda para que o espectador veja um filme em língua estrangeira. Assim, o papel da tradução nesse processo é claramente subordinado e instrumental. Em outras palavras, a tradução é usada como apoio para o filme. ${ }^{122}$ (SUOJANEN et al., 2015, p. 85)

122 "Subtitles are not an independent work of art, or even an independent text. They are a part of a larger, multimodal textual entity, and they are the viewer's aid in watching a foreign-language program. Thus, the role of a translation in the viewing process is clearly subordinate and instrumental. In other words, the translation is used as support in the viewing." 


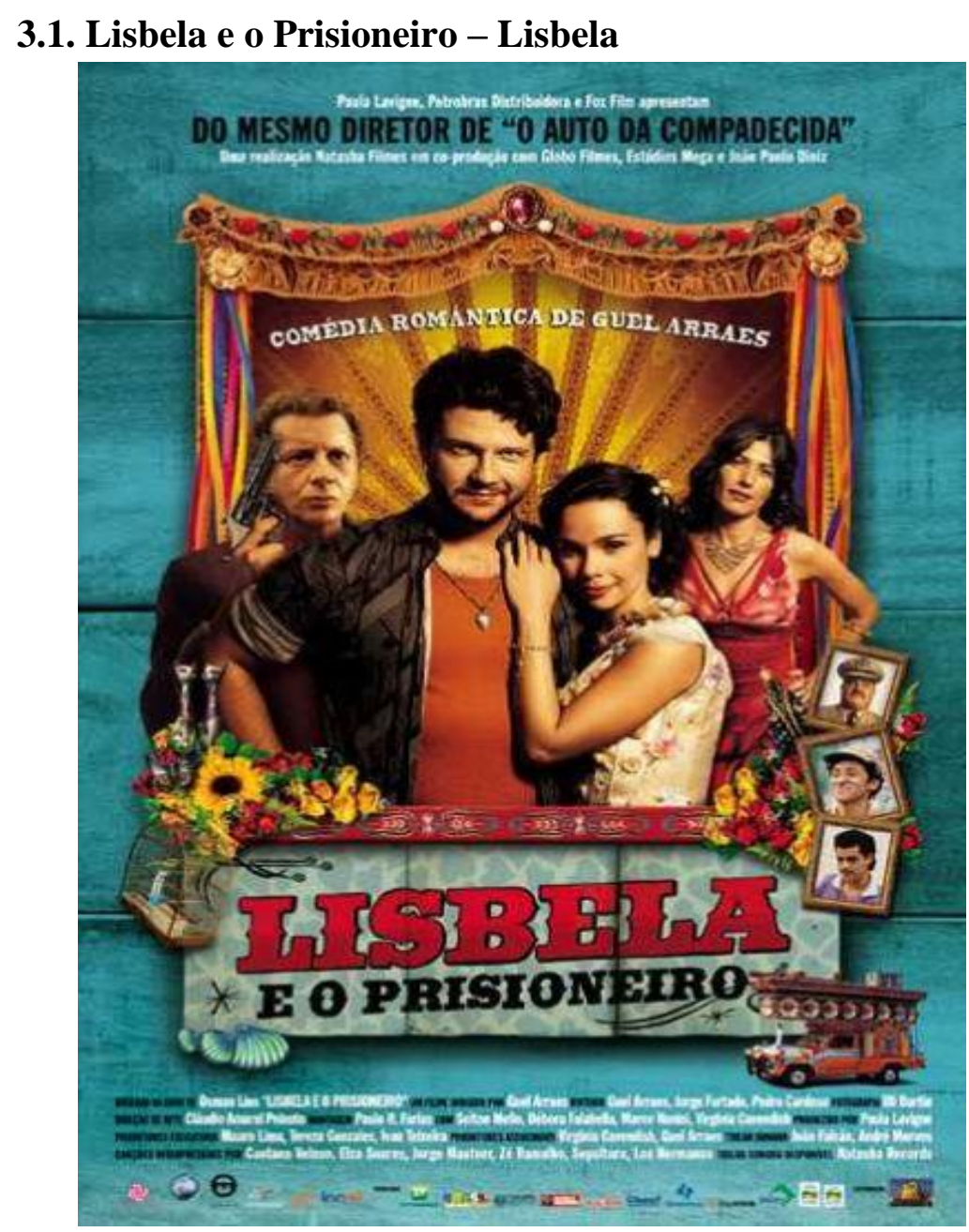

Figura 5. Capa do DVD do filme Lisbela e o prisioneiro.

O filme Lisbela e o Prisioneiro é uma produção brasileira de Guel Arraes, de 107 minutos, sendo o DVD uma produção de Paula Lavigne, Petrobras Distribuidora e Fox Home Entertainment, realização de Natasha Filmes em coprodução com Globo Filmes, Estúdios Mega e João Paulo Diniz. É uma comédia romântica de classificação livre, baseada na obra de Osman Lins e "conta a história divertida do malandro, aventureiro e conquistador Leléu (Selton Mello) e da mocinha sonhadora Lisbela (Débora Falabella), que adora ver filmes americanos e sonha com os heróis do cinema."

A história, segundo a descrição do DVD:

Lisbela está noiva e de casamento marcado, quando Leléu chega à cidade. O casal se encanta e passa a viver uma história cheia de personagens tirados do cenário nordestino. Eles vão sofrer pressões da família, do meio social e também com as suas próprias dúvidas e hesitações. Mas, em uma reviravolta final, cheia de bravura 
e humor, eles seguem seus destinos. Como a própria Lisbela diz, a graça não é saber o que acontece. É saber como acontece e quando acontece.

Há diversas situações cômicas ou espirituosas no decorrer do filme. Para efeitos de visualização, cada trecho será analisado individualmente. As barras [/] mostram as divisões das legendas. No filme Lisbela e o Prisioneiro, as legendas são centralizadas na parte inferior da tela, com caracteres de cor branca com bordas pretas, como é o usual na indústria cinematográfica brasileira.

\begin{tabular}{|c|c|c|}
\hline Minutagem & Fala do personagem & Tradução/Legenda \\
\hline 03:31 & $\begin{array}{l}\text { Leléu: Povo de } \\
\text { Paudalho, onde há vida, há } \\
\text { esperança. E o que eu trago } \\
\text { aqui dentro deste carro não é } \\
\text { milagre, não é macumba, não é } \\
\text { catimbó. Não vacina contra } \\
\text { sogra, não combate praga de } \\
\text { madrinha. Ele não dá cabelo a } \\
\text { careca, braço a cotó, nem } \\
\text { vergonha a quem não tem. A } \\
\text { mercadoria que eu tenho para } \\
\text { oferecer não cura todos os } \\
\text { males, mas só um: o mal de } \\
\text { amor. Não dá jeito em todas as } \\
\text { doenças, mas apenas em uma: a } \\
\text { fraqueza do homem. Não alivia } \\
\text { todas as dores, mas acaba com } \\
\text { a pior delas, que é a dor de } \\
\text { corno. }\end{array}$ & $\begin{array}{l}\text { People of Paudalho, where } \\
\text { there is life, there is hope./ And } \\
\text { what I have inside this truck isn't a } \\
\text { miracle,/ black magic or } \\
\text { witchcraft./ It won't keep your } \\
\text { mother-in-law away or protect you } \\
\text { from the evil eye./ It won't furnish } \\
\text { hair to the bald, arms to the } \\
\text { armless,/ or shame to the } \\
\text { shameless. The product I have to } \\
\text { offer/ doesn't cure all ills, just one: } \\
\text { the malady of love./ It doesn't } \\
\text { work against all sicknesses, just } \\
\text { one:/ a man's weakness. It doesn't } \\
\text { relieve all pains,/ it only puts an } \\
\text { end to the worst one: the pain of } \\
\text { being a cuckold./ }\end{array}$ \\
\hline
\end{tabular}


Neste trecho, logo no início do filme, a passagem humorística tem aspectos visuais incluídos, que é quando o personagem principal chega de caminhão à cidade de Paudalho, anunciando um produto milagroso. Não houve nenhuma omissão de caráter linguístico, em princípio, visto que os termos muito específicos da região, como 'catimbó' ou 'cotó', não foram eliminados; houve apenas uma 'amenização' na tradução, pois 'witchcraft' e 'armless' não têm o mesmo peso linguístico/regionalista. Ainda que a cidade de Paudalho seja um município real, situado no estado de Pernambuco, o tradutor poderia ter acrescentado um toque humorístico e talvez irônico se houvesse traduzido o nome da cidade para, por exemplo, "Garlicstick" ou "Garlidick". A referência à dor de corno poderia se encaixar no tipo de humor de uma comunidade ou regional/nacional, ainda que a tradução ('pain of being a cuckold') seja bastante pertinente, pois 'cuckold' é um termo pejorativo para designar o homem cuja mulher foi ou é infiel ${ }^{123}$. O que fica sem resposta é se a cultura receptora tem o mesmo entendimento do que está envolvido na descrição da dor de corno. Aqui houve uma explicitação, ainda que mínima, com modulação de 'dor de corno' para 'pain of being a cuckold' (em vez de 'cuckold's pain'); tal acréscimo manteve "a essência da cultura original, mas simplificando o processo de compreensão para o receptor alvo" ${ }^{124}$ (IRALA e FERNÁNDEZ, 2004).

\begin{tabular}{|c|c|c|}
\hline Minutagem & Fala do personagem & Tradução/Legenda \\
\hline $04: 34$ & $\begin{array}{l}\text { Leléu: "Chegue pra lá, } \\
\text { Maria, depois, vamos resolver } \\
\text { essa história mais tarde." } \\
\text { Mas em compensação, } \\
\text { mais tarde dá 1, dá } 2 \text {, dá } 3 \text { horas } \\
\text { da manhã e ele conversando. }\end{array}$ & $\begin{array}{l}\text { "Get away, Maria, get } \\
\text { away, we'll take care of it later."/ } \\
\text { But later, when it's } 1 \\
\text { o'clock, } 2 \text { o'clock, } 3 \text { o'clock in the } \\
\text { morning,/ he's still talking on and } \\
\text { on./ }\end{array}$ \\
\hline
\end{tabular}

\footnotetext{
${ }^{123}$ De acordo com o Urban Dictionary (www.urbandictionary.com), o termo 'cuckold' tem origem em 'cuckoo', que é a ave cuco, cujo hábito parasítico das fêmeas de colocar seus ovos em ninhos alheios pode ter gerado a reputação figurativa de infidelidade.

124 “...la esencia de la cultura original, pero simplificando el proceso de comprensión para el receptor meta."
} 
Nesse caso, o humor com conotação sexual ficou prejudicado quando o tradutor explicitou que os números se referiam a horas passadas e não a possíveis encontros sexuais ou número de coitos, como deixa implícito o texto original em português. Ainda que possa ser considerado humor de uma comunidade específica, a tradução poderia ter se aproximado mais da intenção humorística da fala se eliminasse a palavra 'o'clock' após 1 e 2: “But later, it's 1, 2, 3 o'clock in the morning, he's still talking on and on." A tradução se beneficiaria da tática da supressão.

\begin{tabular}{|l|c|l|}
\hline Minutagem & Fala do personagem & \multicolumn{1}{|c|}{ Tradução/Legenda } \\
\hline $04: 57$ & $\begin{array}{l}\text { Leléu: A bateria colou } \\
\text { as placas uma na outra e o } \\
\text { ponteiro velho do relógio } \\
\text { enferrujou às seis e meia e não } \\
\text { dá meio-dia de jeito nenhum. }\end{array}$ & $\begin{array}{l}\text { His batteries are corroded/ } \\
\text { and the hand of that old clock is } \\
\text { stuck rusted at six-thirty/ and } \\
\text { there's no way it will ever point to } \\
\text { twelve noon./ }\end{array}$ \\
\hline
\end{tabular}

Nesse trecho a tradução foi literal e precisa, ainda que 'corroded' não tenha a mesma intencionalidade de 'colar as placas'. Mas a alusão sexual é mantida e tanto a fala em português quanto o texto em inglês - aliados ao gestual da imagem provocam o riso.

\begin{tabular}{|l|c|c|}
\hline Minutagem & Fala do personagem & Tradução/Legenda \\
\hline $07: 07$ & Prazeres: Você tem & Pleasures: Do you have \\
& diploma de salafrário? & your swindler's diploma?/ \\
Leléu: Tenho, mas é & Leléu: Yes, but it is forged./ \\
& Palsificado. & Pleasures: Very funny. \\
& Prazeres: Gaiato. & \\
\hline
\end{tabular}

Nesse caso a tradução também captou exatamente o jogo de palavras e a tradução literal foi bastante efetiva. No caso de 'gaiato', a tradução/modulação com acréscimo de um 'very' para dar gradação ao 'funny' carregado de ironia é mais 
eficaz que a tradução literal, por 'naughty' ou 'mischievous', por exemplo. A legenda combinada à imagem se mostrou uma solução refinada.

Nesse trecho, o personagem principal recebe a visita de esposas descontentes com o produto por ele vendido. Cabe apontar que os nomes das senhoras não são traduzidos, exceto: 'Prazeres $\rightarrow$ Pleasures' e 'das Dores $\rightarrow$ Pains ${ }^{125}$. A ideia da tradução foi interessante, mas o humor parece ter ficado um pouco fora de contexto e talvez não seja compreensível ao espectador estrangeiro.

\begin{tabular}{|l|c|c|}
\hline Minutagem & Fala do personagem & Tradução/Legenda \\
\hline $10: 50$ & $\begin{array}{r}\text { Lisbela: Tá querendo } \\
\text { jantar na hora do almoço, é? } \\
\text { Douglas: É que quanto } \\
\text { mais a hora vai chegando, mais } \\
\text { fome vai dando. }\end{array}$ & $\begin{array}{l}\text { Lisbela: You want to have } \\
\text { to mealtime, the hungrier people } \\
\text { get./ }\end{array}$ \\
\hline
\end{tabular}

O trecho acima foi traduzido quase literalmente e manteve a característica de humor; não obstante, a referência talvez não seja prontamente compreendida, ainda que possa ser inferida. Esse é o tipo de humor que é bastante regional, muito específico de uma comunidade ou região, e até mesmo em outras partes do Brasil a menção seria à 'sobremesa antes do almoço' e não ao ‘jantar na hora do almoço'. A alusão sexual é subentendida, tanto no original quanto na tradução.

\begin{tabular}{|l|c|c|}
\hline Minutagem & Fala do personagem & Tradução/Legenda \\
\hline $11: 44$ & Pai: Acontece um & Father: There's some stuff \\
& $\begin{array}{c}\text { Lisbela: Um troço? } \\
\text { Pai: Sim, filha, a moça }\end{array}$ & $\begin{array}{c}\text { Father: Yes, child,/ the girl } \\
\text { that happens.../ } \\
\end{array}$ \\
& torna-se mulher... \\
\hline
\end{tabular}

\footnotetext{
${ }^{125}$ Não se buscou a equivalência de Prazeres - Joys e Dores - Sorrows, que são nomes (ainda que utilizados em contextos religiosos) existentes na língua/cultura alvo.
} 
A referência humorística aqui é quase exclusivamente visual, pois não há muita fala e é uma situação em que o gatilho do humor seria rir 'de' e não rir 'com'. A tradução de 'troço' por 'stuff' é correta, mas o efeito humorístico poderia transparecer mais se fosse traduzido por 'this thing' ou 'whatchamicallit'. Qualquer uma das opções caberia sem problemas na legenda e possivelmente seria mais espirituoso.

\begin{tabular}{|c|c|c|}
\hline Minutagem & Fala do personagem & Tradução/Legenda \\
\hline $27: 06$ & $\begin{array}{l}\text { Douglas: Pra essa } \\
\text { Paraíba virar macaco falta tão } \\
\text { pouco que a entrada devia ser } \\
\text { franca. }\end{array}$ & $\begin{array}{l}\text { For as little as it will take to } \\
\text { turn this hick into an ape,/ the } \\
\text { ticket should be free. }\end{array}$ \\
\hline
\end{tabular}

Nesse trecho a linguagem da tradução parece estar um pouco truncada, talvez a escolha gramatical não tenha sido a mais apropriada; houve uma transposição gramatical. O entendimento ficou prejudicado pela tradução talvez por demais preciosista e, com ele, o humor pretendido. É um comentário preconceituoso que deve ser entendido dentro do contexto regional; a alusão à 'Paraíba' ${ }^{126}$ referindo-se a uma mulher da região, com a tradução 'hick', que seria 'jeca', 'caipira'. Uma opção mais compacta e pontual seria a utilização da ordem direta: "Well, this hick is almost an ape. The ticket should be free." ou algo semelhante, mas que não fosse de leitura difícil, pois, de acordo com Ridd (1996, p. 477), “a legenda não deve ser somente um elemento comunicativo, mas também capaz de transmitir prazer linguístico."

\begin{tabular}{|l|c|c|}
\hline Minutagem & Fala do personagem & Tradução/Legenda \\
\hline $37: 40$ & $\begin{array}{c}\text { Narrador: Será que } \\
\text { nosso herói aguenta o tranco da } \\
\text { besta-fera das Alagoas? Ou ele }\end{array}$ & $\begin{array}{c}\text { Will our hero survive the } \\
\text { threat from the wild beast from } \\
\end{array}$ \\
\hline
\end{tabular}

126 "Paraíba" pode ser usado para definir várias coisas; no caso, trata-se de uma mulher. No nordeste do Brasil, chamar uma mulher de Paraíba é considerá-la forte e lutadora; já no sul do país, Paraíba pode se referir a qualquer nordestino ou a uma mulher de aspecto e comportamento masculinos. 


\begin{tabular}{|l|l|l|l|}
\hline & $\begin{array}{l}\text { agora se estupora e termina } \\
\text { batendo a caçoleta? }\end{array}$ & $\begin{array}{l}\text { wounded/ and end up six feet } \\
\text { under?/ }\end{array}$ \\
\hline
\end{tabular}

Aqui há muitas referências regionais, como 'aguentar o tranco', 'besta-fera', 'estuporar' e 'bater a caçoleta'. A tradução encontrou soluções eficazes, mas ainda assim algumas das referências culturais foram prejudicadas, não só pelas escolhas tradutórias, mas principalmente pelo espaço exíguo da legenda, que impediu a explicitação. A expressão 'mortally wounded' extrapola a ideia de estuporar, que seria 'paralisar' ou 'arruinar'; poderia ser substituída por 'blown out', passando também a informalidade do texto original. O uso de 'end up six feet under' também traduz precisamente a ideia de 'bater a caçoleta', mas também poderia ser substituído por 'kick the bucket', que talvez soasse mais regionalista. Não obstante, o gatilho de humor está presente, e tanto o significado quanto a forma linguística e a função comunicativa permanecem subjacentes na tradução. Os elementos visuais - o rosto tenso, o olhar malvado - reforçam a fala e a tradução legendada.

\begin{tabular}{|c|c|c|}
\hline Minutagem & Fala do personagem & Tradução/Legenda \\
\hline $43: 28$ & $\begin{array}{l}\text { Cabo: Minha mulher } \\
\text { parece mais um papagaio. } \\
\text { Leléu: Como é isso? Ela } \\
\text { é verde? } \\
\text { Cabo: Não, mas fala sem } \\
\text { parar. } \\
\text { (...) } \\
\text { Cabo: Depois come que } \\
\text { é só uma gota. }\end{array}$ & $\begin{array}{l}\text { Corporal: My wife is like a } \\
\text { parrot./ } \\
\text { Leléu: How's that? Is she } \\
\text { green? } \\
\text { Corporal: No, but she never } \\
\text { stops talking./ } \\
\qquad \text { (...) } \\
\text { Corporal: Besides that, } \\
\text { she's eating me out of house and } \\
\text { home!/ }\end{array}$ \\
\hline
\end{tabular}

A piada aqui é curta e traduzida literalmente, sem qualquer perda de significado. Houve uma substituição na segunda parte, tendo o tradutor encontrado uma expressão tão antiga como '[...] que é só uma gota' e com a mesma intenção 
regionalista, bastante específica. A substituição com acréscimo foi uma estratégia bastante eficaz.

Há nessa passagem do filme uma música, "Você não me ensinou a te esquecer" ${ }^{\prime 27}$, do compositor e cantor Caetano Veloso, que poderia também fazer parte das legendas. Não entraria na categoria humorística em si, pois não é cômica ou espirituosa, mas certamente auxiliaria na compreensão do momento do filme. De certa forma, ela pode ser considerada 'humorística' porque dá um toque de ironia ao dilema pelo qual passam os personagens. Segundo Díaz-Cintas (2007, p. 9), a informação contida na trilha sonora também seria objeto de legendagem; aqui, a música é quase um personagem. No entanto, talvez "devido ao espaço limitado destinado às legendas, certos elementos da trilha sonora precisam ser omitidos" (DÍAZ-CINTAS e ANDERSON, 2009, p. 25).

\begin{tabular}{|c|c|c|}
\hline Minutagem & Fala do personagem & Tradução/Legenda \\
\hline 53:05 & $\begin{array}{l}\text { Douglas: ...uma parada } \\
\text { que aconteceu comigo... com } \\
\text { um amigo meu, que acha que } \\
\text { foi corno. } \\
\text { Tenente: Às suas ordens, } \\
\text { Douglas. Salientando que eu } \\
\text { tenho apenas o conhecimento } \\
\text { teórico do assunto. } \\
\text { Cabo: Nessa matéria, } \\
\text { prefiro ser ignorante. } \\
\text { Tenente: E eu pra corno } \\
\text { sou vacinado. } \\
\text { Douglas: Você acha que } \\
\text { um homem pode ser corno } \\
\text { antes do casamento? }\end{array}$ & $\begin{array}{l}\text { Douglas: It's about } \\
\text { something terrible that happened to } \\
\text { me.../ to a friend of mine,/ who } \\
\text { thinks he's been cuckolded./ } \\
\text { Chief: At your service, } \\
\text { Douglas./ Let me emphasize that I } \\
\text { only have a theoretical knowledge } \\
\text { of the subject./ } \\
\text { Corporal: On this topic, I } \\
\text { prefer to be ignorant./ } \\
\text { Chief: And I'm immune./ } \\
\text { Douglas: Do you think a } \\
\text { man can be cuckolded before he } \\
\text { gets married?/ }\end{array}$ \\
\hline
\end{tabular}

\footnotetext{
${ }^{127} \mathrm{https}: / / \mathrm{www} \cdot$ youtube.com/watch?v=L1tidRNvd6Y

128 "Because of the limited space generally available for subtitles, certain elements of the soundtrack have to be omitted."
} 


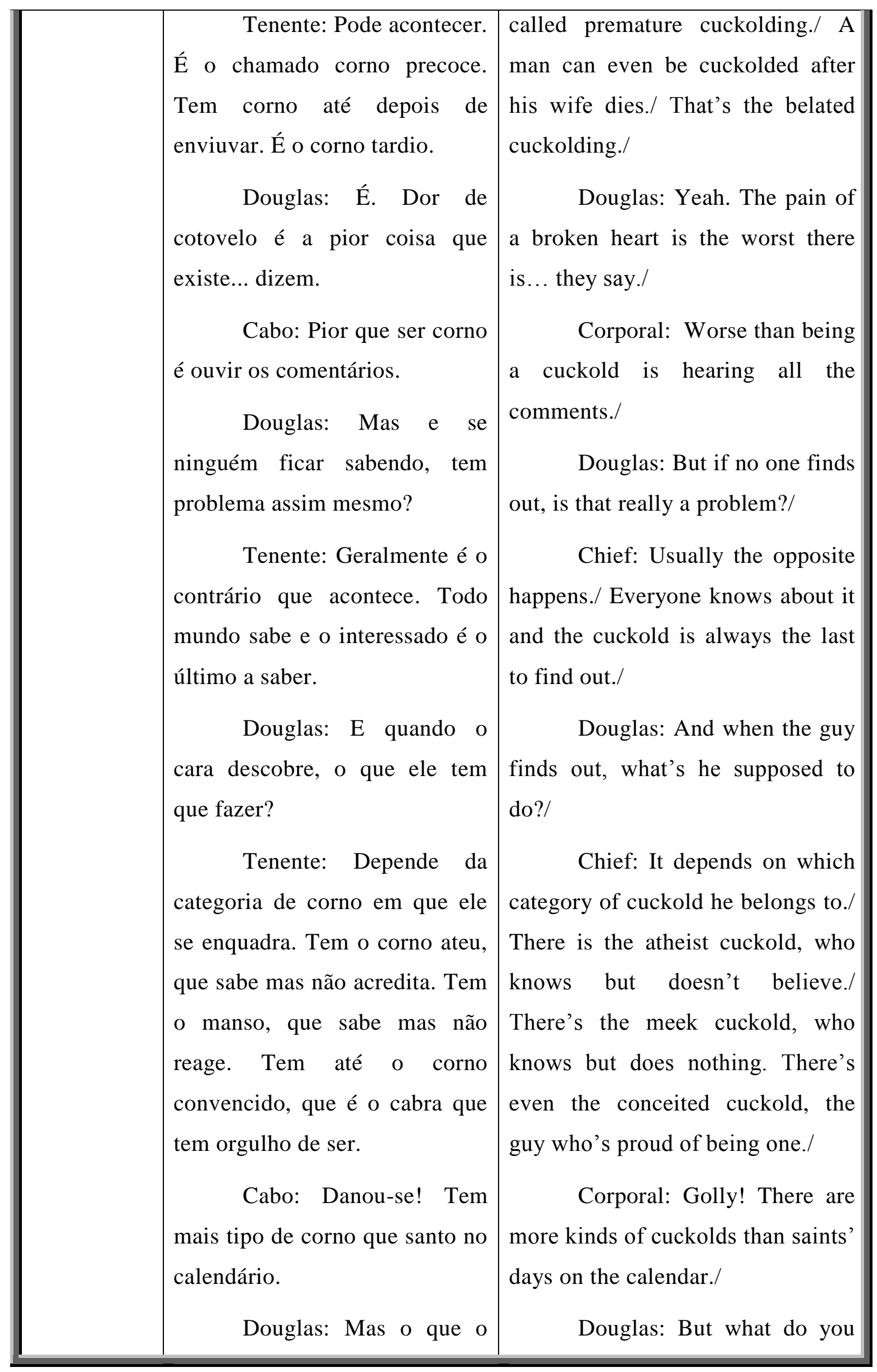




\begin{tabular}{|c|c|}
\hline $\begin{array}{l}\text { senhor acha que um homem } \\
\text { deve fazer quando descobre que } \\
\text { foi corneado? } \\
\text { Tenente: Tem que matar } \\
\text { o cara que o enfeitou. } \\
\text { Douglas: E se o mané } \\
\text { não tiver coragem de matar? } \\
\text { Tenente: Ihh, essa é a } \\
\text { pior qualidade de corno que } \\
\text { tem. É o corno frouxo. }\end{array}$ & $\begin{array}{l}\text { think a man should do/ when he } \\
\text { discovers he's been cuckolded?/ } \\
\text { Chief: He has to kill the guy } \\
\text { who put horns on him./ } \\
\text { Douglas: And what if this } \\
\text { fellow doesn't have the guts to } \\
\text { kill?/ } \\
\text { Chief: That's the worst } \\
\text { category there is./ That's the } \\
\text { cowardly cuckold./ }\end{array}$ \\
\hline
\end{tabular}

A sequência acima faz uma descrição detalhada dos tipos de corno existentes. A tradução meticulosa traz todos os elementos espirituosos do trecho sem precisar fazer uso de substituições ou supressões. Logo no início há um acréscimo que pode ser considerado desnecessário, pois já diz que é uma coisa 'terrível', o que não está explícito - nem implícito - na fala. Depois, a solução para 'dor de cotovelo' (the pain of a broken heart), ainda que não exatamente precisa, também faz menção a uma parte do corpo - cotovelo, coração - e sugere uma explicitação. O que permanece incerto é se a referência a 'cornos' é tão forte para outra cultura que não seja a brasileira. Não obstante, a tradução mantém o efeito cômico da situação. O único trecho que talvez pudesse ser mais elaborado seria a fala do tenente, que diz que "Tem que matar o cara que o enfeitou", traduzido por "He has to kill the guy who put horns on him". Talvez o uso de 'embellish' ou 'adorn' traria um sentido mais irônico, como pretendido na fala. A tradução de "danou-se" pela interjeição "golly" foi uma das raras vezes em que não houve supressão de elementos desnecessários à legenda, que não têm conteúdo semântico.

\begin{tabular}{|l|c|c|}
\hline Minutagem & Fala do personagem & Tradução/Legenda \\
\hline $1: 09: 02$ & Tenente: Cabo Citonho, & Chief: Corporal Citonho, \\
& ponha esse homem na cela. & put this man in the saddle./ \\
\hline
\end{tabular}




\begin{tabular}{|l|l|l|} 
Leléu: Pra que sela? E & \multicolumn{1}{|c|}{$\begin{array}{l}\text { Leléu: Why do I need a } \\
\text { eu vou andar a cavalo pra } \\
\text { precisar de sela? }\end{array}$} \\
$\begin{array}{l}\text { Cabo: A cela que ele tá } \\
\text { horseback?/ } \\
\text { falando é com c cedilha. }\end{array}$ & $\begin{array}{l}\text { Corporal: It's a nickname. } \\
\text { "The saddle" is the cell in the } \\
\text { middle./ }\end{array}$ \\
\hline
\end{tabular}

Este talvez seja o trecho humorístico com jogo de palavras com maior dificuldade de tradução. O humor aqui é puramente linguístico, que faz uso de elementos específicos da língua portuguesa. Primeiro temos os homófonos 'cela' e 'sela' e depois o 'c cedilha'. Nenhum deles tem correspondência na língua inglesa. Pode-se dizer que a substituição feita pelo tradutor foi bastante inteligente e espirituosa, e a ideia de duplo sentido, de 'trapaça linguística', está presente tanto na fala original quanto na tradução para a legenda. A estratégia foi precisa e a mão do tradutor não ficou perceptível. Essa é uma das instâncias em que se demonstra a análise dos aspectos intratextuais e extratextuais da ação comunicativa e translacional; os elementos relevantes no que diz respeito à função do texto fonte foram respeitados e mantidos na tradução, ainda que a execução tenha extrapolado a perspectiva linguística e passado a uma perspectiva semântica (c cedilha - cell in the middle).

\begin{tabular}{|c|c|c|}
\hline Minutagem & Fala do personagem & Tradução/Legenda \\
\hline $1: 21: 01$ & $\begin{array}{l}\text { Frederico Evandro: } \mathrm{O} \\
\text { que você tem entre as pernas } \\
\text { não mata nem passarinho. } \\
\text { Francisquinha: Eita, tava } \\
\text { bem engatilhado, desarmou foi } \\
\text { no susto. } \\
\text { Frederico Evandro: } \\
\text { Quem é essa mulher? }\end{array}$ & $\begin{array}{l}\text { Frederico Evandro: What } \\
\text { you have between your legs } \\
\text { wouldn't hurt a fly./ } \\
\text { Frannie: It was well cocked } \\
\text { before, it was the fright that } \\
\text { disarmed it./ } \\
\text { Frederico Evandro: Who's } \\
\text { this woman? }\end{array}$ \\
\hline
\end{tabular}




\begin{tabular}{|l|l|l|}
\hline \multicolumn{1}{|c|}{ Cabo: É minha esposa. } & \multicolumn{2}{|c|}{ Corporal: My wife, sir./ } \\
Frederico Evandro: Mas & \multicolumn{1}{|l|}{$\begin{array}{l}\text { Frederico Evandro: But } \\
\text { é alimentar pinto com pão-de- } \\
\text { ló. }\end{array}$} & $\begin{array}{l}\text { that's like feeding steak to a } \\
\text { worm!/ }\end{array}$ \\
\hline
\end{tabular}

Esse trecho foi selecionado para ilustrar não só o enunciado espirituoso, como também a solução tradutória, que utilizou paráfrase e substituição compensatória, como se vê em 'matar passarinho' $\rightarrow$ 'hurt a fly' e 'alimentar pinto com pão-de-ló' $\rightarrow$ 'feed steak to a worm'. Foram soluções criativas e pertinentes, que mantiveram a informalidade do original, demonstrando claramente a ação translacional integral. Nas palavras de Reiss (NORD, 2005, p. 9), a tradução ideal seria aquela "na qual o objetivo na LA [língua alvo] é a equivalência no que se refere ao conteúdo conceitual, à forma linguística e à função comunicativa de um TF

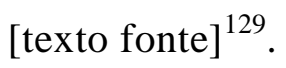

\begin{tabular}{|c|c|c|}
\hline Minutagem & Fala do personagem & Tradução/Legenda \\
\hline $1: 26: 00$ & $\begin{array}{l}\text { Leléu: } \\
\text { ajudaum. Domininha } \\
\text { Ainda bem que cheguei a } \\
\text { tempum. Ficares quietus, num } \\
\text { falares nadum. Dê um fim nesse } \\
\text { casamentum, em nome do } \\
\text { Espírito Santo... Largai desse } \\
\text { alesadus e me encontrai atrás da } \\
\text { igrejam Espirito Santi... }\end{array}$ & $\begin{array}{l}\text { Leléu: Little girl help } \\
\text { meum. Dominis, dominis./ I got } \\
\text { here just in timehum./ Keep } \\
\text { quietum, don't give me awayii./ } \\
\text { And let's stoppis this weddingum } \\
\text { by the Holy Spirito Santi.../ Lose } \\
\text { that halfwittus, meet me behindus } \\
\text { the churcham,/ Spirito Santi.../ }\end{array}$ \\
\hline
\end{tabular}

Mais uma vez, o trecho escolhido demonstra a criatividade do tradutor ao selecionar a estratégia tradutória, desde a escolha vocabular à latinização das palavras. Talvez a única opção que poderia ser modificada seria a de 'awayii', pois

\footnotetext{
129 "in which the aim in the TL [target language] is equivalence as regards the conceptual contente, linguistic form and communicative function of a SL [source language] text."
} 
não soa como latim de missa e não tem similares no texto. Uma solução possível seria 'awayum'.

Há várias outras passagens humorísticas no filme. Os trechos assinalados demonstram tanto a criatividade quanto a priorização de estratégias feitas pelo tradutor ao longo do filme. Não há instâncias significativas de desvantagem linguística ou supressão tradutória, apesar da dificuldade imposta pelo texto original, de cunho bastante regionalista. Mas um texto transcultural é possível, como afirma Possenti (1998, apud ROSAS, 2002, p. 39):

É verdade, pois, que as piadas são culturais, até mesmo em sentido estrito. Mas, menos do que poderia parecer, se com isso se quiser dizer que para cada grupo social ou país os fatores relevantes são muito específicos. Às vezes, ao contrário do que se diz correntemente, poder-se-á ser levado a pensar que as piadas são quase universais... não só no sentido de que quase todos os povos produzem piadas, mas no sentido de que elas versam sobre poucos tópicos, sempre os mesmos, e variam apenas como decorrência de certas especificidades linguísticas. 


\subsection{A Marvada Carne - Strong Meat}

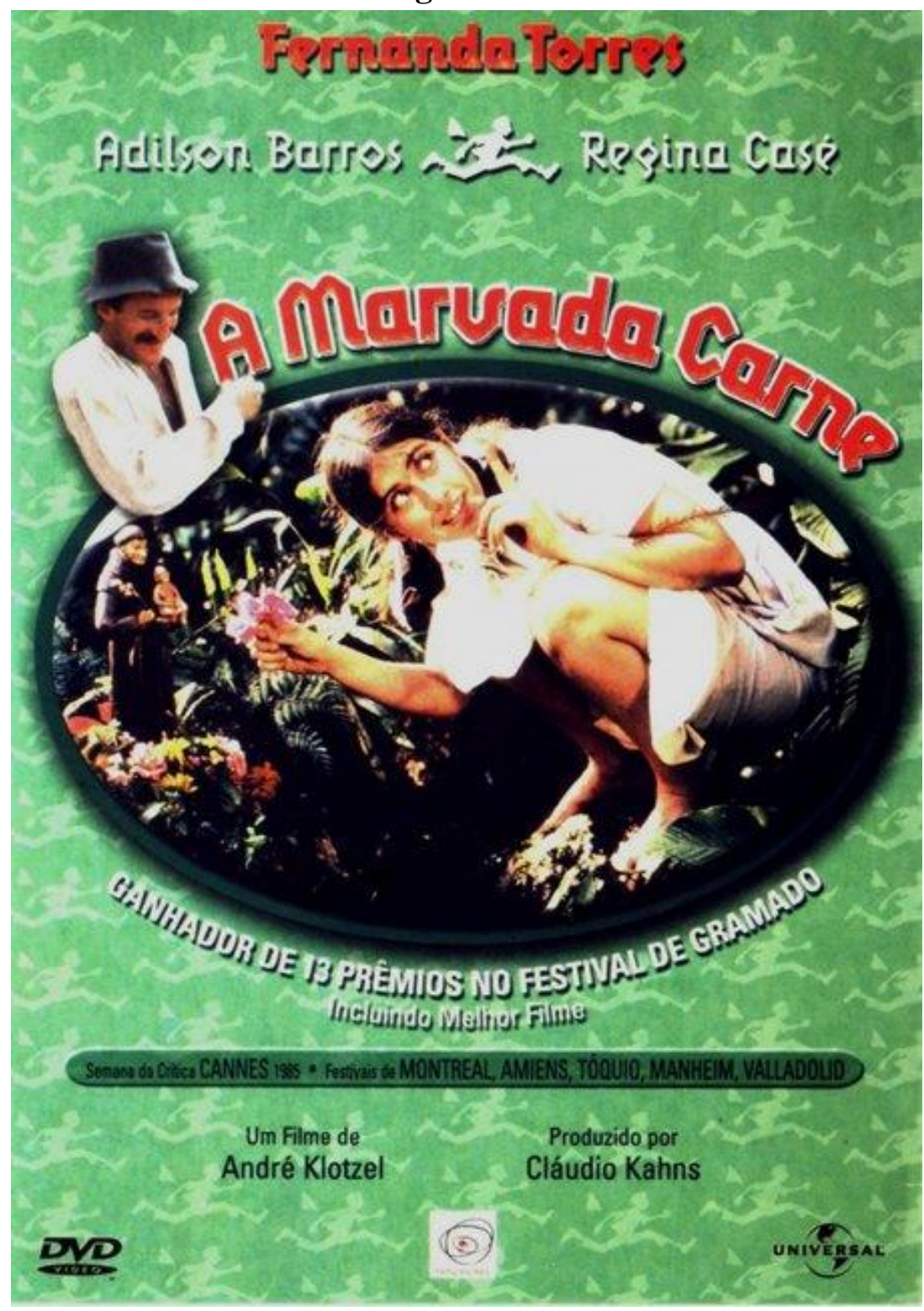

Figura 6. Capa do DVD do filme A marvada carne.

A Marvada Carne é um filme de 1985, produzido por Cláudio Kanhs, da Tatu Filmes, dirigido por André Klotzel e estrelado por Fernanda Torres, Adilson Barros e Regina Casé. Ganhou onze prêmios no Festival de Gramado, no mesmo ano em que foi lançado, incluindo Melhor Filme pelo Júri Oficial e pelo Júri Popular. A Marvada Carne é uma comédia que mostra as hilariantes aventuras de Carula (Fernanda Torres), uma garota simples, do interior, que tem um grande sonho na vida: casar-se. E para isso ela está disposta a tudo.

A história, segundo a descrição do DVD: 
Nhô Quim vive lá nos cafundós em companhia do cachorro e da cabra de estimação. Aquela vidinha besta no meio do mato não dá pé e ele resolve cair no mundo e procurar a solução para duas questões que o incomodam: arranjar uma boa moça para o casório e comer a tal carne de boi, um desejo que fica ruminando sem parar dentro dele. Nas suas andanças Nhô Quim vai dar na casa de Nhô Totó e Nhá Policena, cuja filha, Sá Carula, está em conflito com Santo Antônio, que não anda colaborando para ela arranjar um bom partido. E logo Nhô Quim descobre que o pai da moça tem um boi reservado para a ocasião do casamento da filha. Será este o momento para Nhô Quim realizar seus dois maiores desejos?

As legendas desse título são amarelas com bordas pretas, um pouco maiores que as legendas padrão utilizadas em filmes para DVD mais recentes. Estão centralizadas na parte de baixo da tela. A leitura é fácil e fluida, ainda que a cor seja um pouco forte demais e chame muita atenção para a legenda.

\begin{tabular}{|c|c|c|}
\hline Minutagem & Fala do personagem & Tradução/Legenda \\
\hline $07: 18$ & $\begin{array}{l}\text { [música] Santo Antônio } \\
\text { venerado } \\
\text { Meu santinho namorado } \\
\text { Encontra o que tá } \\
\text { perdido } \\
\text { Me ajuda a encontrar } \\
\text { marido } \\
\text { Eu fui no mato cortar } \\
\text { lenha, Santo Antônio me } \\
\text { chamou. } \\
\text { Se santo que é santo me } \\
\text { chama }\end{array}$ & $\begin{array}{l}\text { [song] "Santo } \\
\text { Antonio"/That I revere } \\
\text { My little sant/So very dear } \\
\text { A plea for help/Will you } \\
\text { heed } \\
\text { Find me the husband/That I } \\
\text { need so } \\
\text { I went to the bush/to cut } \\
\text { some wood } \\
\text { "Santo Antonio" beckoned } \\
\text { me If that's a saint } \\
\text { behaves/What would a sinner do to } \\
\text { me? Santo Antonio" gave me a } \\
\text { wink/From the top of his altar }\end{array}$ \\
\hline
\end{tabular}




\begin{tabular}{|l|r|r|r|} 
piscou & Antônio me & Take a look at the saucy \\
& De cima de seu altar \\
saint/Trying to woo me & \\
Santo óia o maluco do & \\
& Querendo me namorar. & \\
\hline
\end{tabular}

Logo no início do filme, a personagem Carula - que é uma adolescente do interior do Brasil que tem o sonho de se casar e para isso pede a benção de Santo Antônio, o santo casamenteiro - canta para uma estatueta de Santo Antônio. A legenda manteve o nome "Santo Antônio" - retenção - e houve uma tentativa de manter a rima em alguns versos. O teor humorístico é uma combinação de elementos visuais (a estatueta do santo com diferentes expressões faciais) e sonoros (a música). Também no início, estabeleceu-se o pronome de tratamento 'nhô' Quim (nhô corruptela de senhor), e 'suh' (a forma regional - sulista - de 'sir'). Por fim, há também no início uma expressão usada pelo pai de Carula que vai se tornar recorrente ao longo do filme: "Me passou" - "Oh, yeah. It slipped my mind". É uma estratégia tradutória de acréscimo, "técnica que pode ser utilizada quando as restrições formais da legendagem possibilitam tal oportunidade"130 (PANEK, 2009, p. 52).

\begin{tabular}{|c|c|c|}
\hline Minutagem & Fala do personagem & Tradução/Legenda \\
\hline $22: 48$ & $\begin{array}{l}\text { Narrador: Hoje em dia } \\
\text { num sei, né? Hoje em dia as } \\
\text { coisas anda muito diferentes. } \\
\text { Mas naquele tempo eu posso } \\
\text { lhe garantir... Que quem } \\
\text { bebesse no copo de um } \\
\text { estrupício qualquer... Que }\end{array}$ & $\begin{array}{l}\text { Narrator: Nowadays/I don’t } \\
\text { know any more. } \\
\text { Nowadays/things are } \\
\text { different. } \\
\text { In those days/I can } \\
\text { guarantee... }\end{array}$ \\
\hline
\end{tabular}

130 "The technique can be applied when the formal constraints of subtitling offer such an opportunity." 


\begin{tabular}{|l|l|l}
\hline $\begin{array}{l}\text { descobria os segredos dele. Ah, } \\
\text { isso descobria mesmo. }\end{array}$ & that if you drank/in \\
& someon's glass... & \\
& you'd find out his \\
& secrets./All of them.
\end{tabular}

Não foram reproduzidas as incorreções gramaticais da fala; como mencionado anteriormente, a ideia é que a legenda 'coopere' com o espectador, que seja um elemento harmônico do filme. As incorreções foram eliminadas também porque, como afirma Gorovitz (2006, p. 10), a legendagem "não deixa de ser um elemento intruso à obra"; assim, uma tentativa de reproduzir a incorreção no texto escrito poderia ser considerada intrusiva, não reproduziria o valor da fala e seria visto apenas como uma falha ou um erro ortográfico. A tradução de 'estrupício' por ‘someon' (grafado incorretamente) foi uma generalização, pois eliminou qualquer imagem mental de um estrupício ${ }^{131}$.

\begin{tabular}{|l|l|r|r|}
\hline Minutagem & Fala do personagem & \multicolumn{2}{|c|}{ Tradução/Legenda } \\
\hline $25: 12$ & $\begin{array}{l}\text { Nhô Quim: Nunca ouviu } \\
\text { dizer? Rio que moça donzela } \\
\text { toma banho pelada.. nunca } \\
\text { mais dá peixe. }\end{array}$ & $\begin{array}{r}\text { Suh Quim: Haven't ever } \\
\text { heard? }\end{array}$ \\
\hline
\end{tabular}

A solução tradutória para esse trecho que tem um toque bem regionalista foi a adição de elementos (pelada $=$ in the raw) e a utilização - talvez não intencional - de rima. O duplo, ou triplo, negativo da última frase foi uma modulação e uma explicitação ou explicação, e foi bastante efetiva. Há uma falha tradutória grave aos 30 minutos do filme; uma música - uma moda de viola - que, além de não ser traduzida (provavelmente causando frustração no espectador de língua estrangeira), é legendada em português. Não há razão alguma para isso, já que a música é de

\footnotetext{
${ }^{131}$ Estrupício = um estorvo, um encosto que só atrapalha e incomoda o outro.
} 
compreensão relativamente fácil - apesar das incorreções gramaticais e lexicais, além dos erros em português - e certamente tal expediente pode ter o efeito de aborrecer o espectador, que não vai compreender o que está escrito, mas ao mesmo tempo vai continuar a leitura; a legenda será ainda mais intrusiva e, nesse caso, vai criar uma barreira que pode gerar um sentimento de perda irreparável no telespectador. A impressão que se tem é que o tradutor/legendador transferiu sua 'melancolia benjaminiana' para o espectador; houve uma renúncia que, segundo Gottlieb (2005), é a escolha pela não tradução.

O sór já vem despontando

Abre a porta moça não (*no salão)

Não é que eu tenha pressa

Nem deixa a sua função

$\mathrm{Eu}$ sou um rapaz sorteiro

Pra trai não deixou pensão (*deixo)

É dispensar o casado

Pra cuidar da obrigação

Chega pra cá rapaziada

Vamo reuni os cortazão

Traçar uma roda bem feita

No meio deste salão

Vamo riti com a viola (*repicar a viola)

Pra bater o pé no chão

Vou repeti o sapatiado

Pra despedir da canção (*função)

Abra a porta ou a janela

Venha ver quem é que eu sou

Sou aquele desprezado 
Que você mesmo (*me) desprezou ${ }^{132}$

\begin{tabular}{|c|c|c|}
\hline Minutagem & Fala do personagem & Tradução/Legenda \\
\hline $1: 06: 29$ & $\begin{array}{l}\text { Nhô Quim: É gordo, né? } \\
\text { Vendedor: Gordo. É, o } \\
\text { senhor precisa conhecer o } \\
\text { nosso carnê. } \\
\text { Nhô Quim: De boi? } \\
\text { Vendedor: Carnê. } \\
\text { Nhô Quim: Carne. } \\
\text { Vendedor: Carne de boi, } \\
\text { claro. O senhor está falando } \\
\text { com a pessoa certa. } \\
\text { Vai levar a boiada toda } \\
\text { ou é um só? } \\
\text { Nhô Quim: Num dá pra } \\
\text { entendeu? O senhor me dá a } \\
\text { grana já que facilita. } \\
\text { fevar esse negócio aí. A gente } \\
\text { fazer no picado? } \\
\text { Vendedor: No picado? }\end{array}$ & $\begin{array}{l}\text { Suh Quim: -It's a fat one, } \\
\text { huh? } \\
\text { Salesclerk: -Fat indeed. } \\
\text { Salesclerk: You must } \\
\text { hear/about our installment plan. } \\
\text { Suh Quim: For beef? } \\
\text { Salesclerk:-Installment } \\
\text { plan. } \\
\text { Suh Quim: -Meat. } \\
\text { Salesclerk: } \\
\text { course! Meat, } \\
\text { You're speaking/to the right } \\
\text { (herson. } \\
\text { the cut? } \\
\text { Are you going to take/the } \\
\text { for you. } \\
\text { Suh Quim: Couldn't you } \\
\text { whole herd, or just one? }\end{array}$ \\
\hline
\end{tabular}

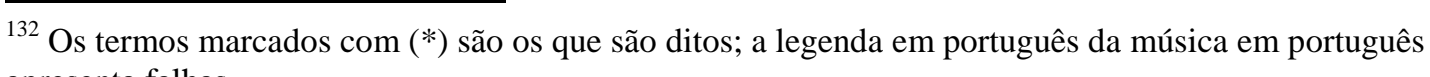
apresenta falhas. 


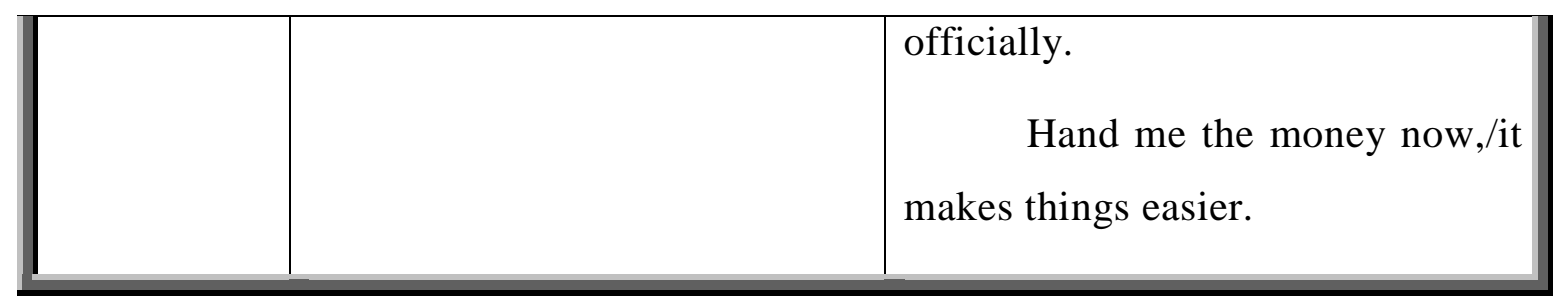

Mais uma vez, a intenção humorística aqui é linguística, isto é, a fala em português faz uma diferenciação apenas na acentuação da palavra (carne - carnê). $\mathrm{Na}$ impossibilidade de brincar com o trocadilho, o tradutor fez uma tradução literal, na qual ignorou o jogo de palavras 'carne x carnê', mas logo em seguida brincou com a palavra 'meat', que é 'carne', mas de certa forma poderia levar o espectador a 'interpretar' os termos e fazer uma referência a 'meet' (conhecer), ainda que a palavra esteja corretamente grafada na legenda. Pode-se dizer que houve supressão do efeito humorístico, que já era velado, pois tampouco fica patente na cena.

\begin{tabular}{|l|c|c|}
\hline Minutagem & Fala do personagem & Tradução/Legenda \\
\hline $1: 11: 30$ & $\begin{array}{r}\text { Narrador: E entonces. } \\
\text { Entonces tem Jacu e tem Jacó. } \\
\text { Tem jaú e tem socó. Entrou por } \\
\text { uma porta e saiu pela outra. E } \\
\text { quem quiser que conte outra. }\end{array}$ & $\begin{array}{c}\text { Narrator: And then./you } \\
\text { give a little... }\end{array}$ \\
& And you take a little. \\
& You gon in one door/and \\
& & And if you want/to tel \\
& & another story, feel free! \\
\hline
\end{tabular}

A fala final do filme é bastante regionalista; as referências a Jacu e Jacó significam pessoas de todos os níveis, do bobo caipira ao nobre; jaú e socó são também referências regionais, um peixe e uma ave, respectivamente. Nesse momento da fala do narrador-personagem, ele já havia trazido a 'famiage'(família) para a 'tar da cidade'; a câmera se abre em panorâmica para mostrar a periferia de uma cidade. A referência maior aqui é a representação do caipira urbanizado, que finalmente conseguiu comer a carne que tanto queria e se estabeleceu em alguma periferia de cidade grande. A carne é a simbologia para a ascensão social. Ele agora 
faz churrasco na laje, o que revê a "coletividade festiva da roça original de Nhô Quim na forma dada pelo novo contexto social" (MEIRA, 2009). Todo o filme é uma alegoria à proletarização urbana, e há a “desagregação dos antigos valores, formas de sociabilidade e crenças, portanto, as antigas raízes do Brasil rural são arrancadas" (PEREIRA, 2007). Não haverá mais histórias de brigas com Santo Antônio, de ludibriar o Curupira e o capeta, de colar nariz do lado oposto; acabou o faz de conta, e há uma ironia fina nisso; talvez por isso a expressão típica para finalizar um conto é utilizada: entrou por uma porta e saiu pela outra, quem quiser que conte outra. É como se o narrador-personagem nhô Quim estivesse num conto fantástico.

A tradução desse trecho fez uso da estratégia de substituição na primeira parte (and then you give a little, and you take a little) que deixa a mesma dúvida em relação à significação e conteúdo semântico da fala original. Em relação à segunda parte, da conhecida expressão que finaliza contos em português, a estratégia utilizada foi a tradução literal ou quase palavra-por-palavra. É interessante salientar que há expressões em inglês tão corriqueiras para finalizar contos como em português; o tradutor poderia ter se utilizado delas: 'and so the story goes', 'snip, snap, snout, this tale's told out', ou 'an' the wheel bend, an' the story end', uma expressão também arraigada, com rima, que se ajustaria ao espaço da legenda. 


\subsection{Quincas Berro D’Água - Quincas Wateryell}

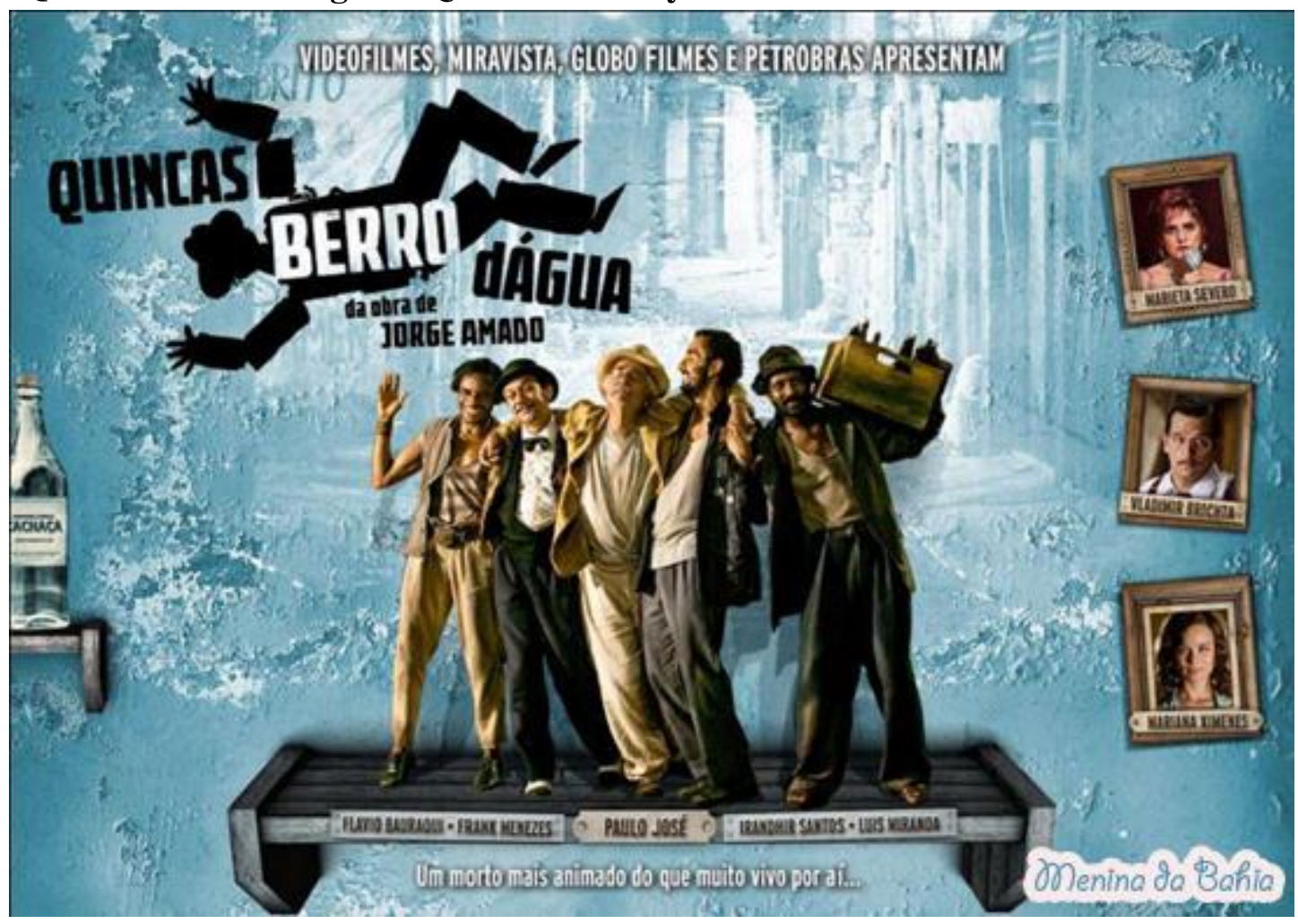

Figura 7. Capa do DVD do filme Quincas Berro D'Água.

Quincas Berro D'Água é um filme brasileiro de 2010, do gênero comédia, dirigido por Sérgio Machado e com roteiro baseado no livro A Morte e a Morte de Quincas Berro d'Água, do escritor Jorge Amado.

Quincas é um homem bruto que mora na região do cais de Salvador. Trabalhador, militante comunista, ateu, beberrão e mulherengo, ele morre ao levar um tiro de um policial durante uma manifestação grevista. É então que Quincas recebe uma missão espírita: perdoar e guiar o policial que o matou para um caminho certo na vida. Desta forma, Quincas pagará sua dívida com Deus e com as pessoas que magoou enquanto vivo.

A história, segundo a descrição do DVD:

Rei dos botecos, bordéis e gafieiras da Bahia, o ex-funcionário público Quincas Berro d’Água é encontrado morto em sua cama. Inconformados com sua morte, seus melhores amigos roubam o corpo e o levam para uma última noite, regada a festa e muita bebida. Em meio a mil confusões, Quincas vive a sua segunda e definitiva morte, desta vez como sempre sonhou. 
Todo o filme é uma brincadeira com a morte, ainda que com uma visão bastante negativa. Cabe ressaltar que o fenômeno da morte tem significação plural e é sui generis a cada cultura; é um elemento social. Nessa obra, o Quincas morto é o Quincas liberto, dos preconceitos, dos padrões sociais, por meio de ironias, chistes, silogismos e trocadilhos. E Quincas só se sente vivo quando está morto.

As legendas desse DVD são brancas com bordas pretas e um sombreamento avermelhado/alaranjado, centralizadas na parte inferior da tela.

\begin{tabular}{|c|c|c|}
\hline Minutagem & Fala do personagem & Tradução/Legenda \\
\hline 3:00 & $\begin{array}{l}\text { Quincas: Eu pensei } \\
\text { comigo... tô ferrado! Era a } \\
\text { morte mandando a conta da } \\
\text { esbórnia, da cachaça } \\
\text { desregrada, das noites na orgia. }\end{array}$ & $\begin{array}{l}\text { Quincas: I thought to } \\
\text { myself... } \\
\text { "I'm fucked"! } \\
\text { It was Death, charging/for } \\
\text { the years of whoring... } \\
\text { the bingeing... } \\
\text { and the nights/in the } \\
\text { brothels. }\end{array}$ \\
\hline
\end{tabular}

A introdução do filme ja tem uma linguagem carregada, acentuada/intensificada na tradução (ferrado $=$ fucked $/$ esbórnia $=$ whoring). A tradução passou por uma aclimatação, mostrando o contexto e identificando, para o espectador, o estilo do filme. Essa contextualização é importante, pois o "contexto geralmente dá ao diálogo mais peso"133 (BANNON, 2010).

\begin{tabular}{|l|c|c|}
\hline Minutagem & Fala do personagem & \multicolumn{3}{|c|}{ Tradução/Legenda } \\
\hline $5: 27$ & Pastinha: Passei no & Greasy: I went by Mãe \\
& $\begin{array}{l}\text { terreiro de Mãe Ana, e na casa } \\
\text { de Benedita Boa Bunda e no }\end{array}$ & $\begin{array}{l}\text { Ana's,/Benedita's and Alonso's } \\
\text { bar. }\end{array}$ \\
\hline
\end{tabular}

133 "Context often gives dialogue great weight." 
Nesse trecho, a omissão de 'terreiro' e 'boa bunda' e o uso da imitação (Mãe Ana) eliminaram referências importantes, ainda que a ideia de terreiro seja de difícil tradução. A primeira referência a Benedita Boa Bunda foi omitida, mas no minuto 32, Benedita Boa Bunda foi traduzida como Benedita GoodArse. A omissão aqui pode ter sido causada pelo espaço exíguo para a legenda.

\begin{tabular}{|l|c|c|}
\hline Minutagem & Fala do personagem & Tradução/Legenda \\
\hline $8: 20$ & Mulher: El buelo. & Woman: -"El Cake-sito"! \\
& Manuela: El buelo? & Manuela: -"El Cake-sito"? \\
& Enfia en el meio del cuelo. & Stick it up your "arse-sito"! \\
\hline
\end{tabular}

A referência humorística aqui foi recriada por meio de adaptação, ou o procedimento de estrangeirismo aclimatado, pois o sufixo [s]ito é uma referência direta e conhecida da língua espanhola para os espectadores de língua inglesa, assim como a ditongação é sinal - utilizado erroneamente - de 'espanholização'. O humor foi mantido e a linguagem sexual também, ainda que arse-sito soe como um diminutivo, amenizando a referência. Aos 9 minutos de filme, uma não tradução chama a atenção: 'cumpadi' é traduzido na legenda por 'compadre'. O espectador/leitor pode ser levado a crer que Compadre é o nome do personagem.

\begin{tabular}{|l|l|l|l|}
\hline Minutagem & \multicolumn{2}{|c|}{ Fala do personagem } & \multicolumn{2}{|c|}{ Tradução/Legenda } \\
\hline $10: 35$ & \multicolumn{1}{|c|}{ Mulher: Eu achei que } & Woman: You seem more \\
& $\begin{array}{l}\text { você está um pouco mais } \\
\text { fortinha. }\end{array}$ & curved, no? & \\
\hline
\end{tabular}

O trecho curto só exemplifica um tipo de linguagem irônica que é muito comum em qualquer cultura - fazer comentários críticos sobre a constituição física das pessoas. A tradução suavizou um pouco a crítica/ironia, pois 'curved' pode ser 
até considerado um adjetivo positivo, e o original em português diz 'fortinha', que é bastante sarcástico. Talvez a adição de 'bit' (a bit more curved) mostrasse uma modulação mais adequada e reforçasse a ironia.

\begin{tabular}{|c|c|c|}
\hline Minutagem & Fala do personagem & Tradução/Legenda \\
\hline $15: 05$ & $\begin{array}{l}\text { Quincas [em off]: } \\
\text { Gostava de tudo do jeito dela e } \\
\text { não comia caruru azedo de } \\
\text { ninguém. }\end{array}$ & $\begin{array}{l}\text { Quincas [off]: Wouldn't } \\
\text { take "no"/for an answer. Took no } \\
\text { shit. }\end{array}$ \\
\hline
\end{tabular}

O tradutor/legendador usou duas expressões idiomáticas para, de certa forma, explicar a fala original. $\mathrm{Na}$ verdade, as duas expressões têm significados semelhantes; pode ser que a omissão dos sujeitos na tradução seja uma estratégia de aproximação da informalidade da fala original. Certamente, seria uma tarefa intrincada traduzir literalmente 'caruru azedo', mas a referência humorística/regional foi perdida. As legendas seriam mais fáceis e agradáveis de ler se cada frase estivesse em uma linha diferente; elas caberiam dentro dos limites estabelecidos, principalmente se as aspas da palavra 'no' fossem eliminadas (Wouldn't take no for an answer. / Took no shit.)

\begin{tabular}{|l|c|c|}
\hline Minutagem & Fala do personagem & Tradução/Legenda \\
\hline $16: 15$ & Pastinha: Ele prometeu & Greasy: He swore he'd be \\
& que ia virar a noite biritando. & on the piss! \\
\hline
\end{tabular}

Nessa frase há a utilização do procedimento de equivalência, pormenorizado por Heloisa Barbosa, que busca uma expressão correspondente à original quando há divergência do sistema linguístico, ou seja, divergências na organização do sistema linguístico, "seja ao nível lexical, morfológico ou sintático e as diversas maneiras como cada sistema linguístico divide e analisa as experiências da realidade extralinguística" (BARBOSA, 2007, p.67) . Aqui o nível de informalidade foi mantido e a pitada humorística também. 


\begin{tabular}{|c|c|c|}
\hline Minutagem & Fala do personagem & Tradução/Legenda \\
\hline $17: 51$ & $\begin{array}{l}\text { Homem: A filha dele } \\
\text { mandou a gente embora. } \\
\text { Mulher: } \\
\text { branquela azeda! Ficava } \\
\text { olhando pra gente como se } \\
\text { tivesse um rei na barriga. } \\
\text { Homem: É melhor não } \\
\text { ter a festa. } \\
\text { Mãe-de-santo: } \\
\text { consultei Iemanjá, ela disse } \\
\text { que a festa vai acontecer. }\end{array}$ & $\begin{array}{l}\text { Man: -His daughter kicked } \\
\text { us out! } \\
\text { Woman: -Stuck-up whitey! } \\
\text { Looked at us like she } \\
\text { was/the Queen of Sheba! } \\
\text { Man: She didn't want us/to } \\
\text { perform the rites. } \\
\text { Mother: I've consulted } \\
\text { Iemanj and/the celebration will be } \\
\text { held. }\end{array}$ \\
\hline
\end{tabular}

Aqui a estratégia usada para a tradução de branquela azeda foi a de aproximação, omitindo a palavra 'azeda', mas compensando com 'stuck-up'; houve uma transposição que manteve a intenção do xingamento, nem aumentando e nem suavizando. A adaptação/equivalência de 'rei na barriga' por 'Queen of Sheba' foi bastante pertinente e manteve o toque de ironia sarcástica do original. Logo em seguida, no entanto, há uma alteração total da fala (É melhor não ter a festa $=$ She didn't want us to perform the rites) que não chega a afetar o diálogo, mas que certamente não faz referência ao que foi dito; é possível que o tradutor/legendador estivesse trabalhando a partir de um script enviado previamente. Por fim, a alteração de 'Iemanjá' para 'Iemanj' parece ter sido causada pela falta de acentos diacríticos nas legendas em inglês, pois não é ocorrência única ao longo do filme; nesse caso, não haveria conflito na tradução, mas uma falha técnica. Aos 20 minutos do filme, há uma tradução literal de um xingamento (Jararacas! = Vipers!) que se encaixou perfeitamente na intenção e propósito da fala original. 


\begin{tabular}{|l|c|c|}
\hline $21: 27$ & Quincas [morto]: Saco & Quincas [dead]: Fart-bag! \\
& de peido! & Trumpet-blowhole! \\
& Cu de corneta! & \\
\hline
\end{tabular}

A tradução desse trecho curto não foi literal, mas utilizou recursos de adaptação e modulação que deram à legenda o mesmo toque de humor que, associado à imagem da situação embaraçosa (a tia acometida pela flatulência), certamente provocou o riso no espectador. O humor que utiliza recursos escatológicos tem o caráter universal e quase sempre gera o riso, até pelo constrangimento que causa.

\begin{tabular}{|l|r|c|}
\hline Minutagem & Fala do personagem & Tradução/Legenda \\
\hline $22: 05$ & $\begin{array}{r}\text { Leonardo: Wanda, pensa } \\
\text { bem, Wanda, olha! O jeito que } \\
\text { ele tá vestido! Todo pimpão! }\end{array}$ & $\begin{array}{c}\text { Leonardo: Look how he's } \\
\text { dressed?/To the nine-pins! }\end{array}$ \\
\hline
\end{tabular}

Esse trecho também curto sinaliza a utilização da omissão ou supressão de palavras sem conteúdo semântico (pensa bem) e a supressão do nome (Wanda). O 'olha' exclamativo foi transposto para a frase seguinte. A expressão 'todo pimpão' é bastante antiga e denota uma pessoa vestida com elegância; janota. O toque de humor/ironia é justamente esse, a incongruência entre o lugar do velório, a própria pessoa que estava sendo velada e a elegância dos trajes. A tradução por 'to the ninepins' parece ter misturado duas expressões da língua inglesa: 'dressed to the nines' (vestido/a elegantemente, como se fosse a uma festa em horário nobre) e 'nine pins', que é uma modalidade do boliche. Talvez o 'pins' tenha sido acrescentado para dar uma ilusão - ou alusão - de aliteração. De toda maneira, a expressão (to the nines) também é antiga e apropriada ao estilo.

\begin{tabular}{|l|l|l|}
\hline Minutagem & Fala do personagem & Tradução/Legenda \\
\hline
\end{tabular}




\begin{tabular}{|c|c|c|}
\hline $25: 16$ & $\begin{array}{l}\text { Mulher: Graças a Deus } \\
\text { era comprimido de magnésio. } \\
\text { Passou o dia todo no banheiro. } \\
\text { Chorando por cima e chorando } \\
\text { por baixo. } \\
\text { Mulher 2: Cada um } \\
\text { chora por onde sente saudade. }\end{array}$ & $\begin{array}{l}\text { Woman: Thank God,/the } \\
\text { pills were Magnesium! } \\
\text { She spent the rest of the } \\
\text { day/in the toilet! } \\
\text { Crying,/from top to bottom! } \\
\text { Woman 2: Each cries/from } \\
\text { where they feel most sad! }\end{array}$ \\
\hline
\end{tabular}

A alusão sexual aparece na tradução deste trecho de forma implícita, com uma modulação gramatical (sente saudade $=$ feel most sad) que, apesar da incorreção, sugere o coito anal. A tradução dessa insinuação foi ligeiramente suavizada - possivelmente pela ausência de um equivalente direto para 'saudade' - e parece mostrar um pouco de auto-censura. No entanto, a referência ficou clara. Segundo Santaemilia (2010, p. 128), “a tradução dos episódios amorosos ou das sugestões sexuais não se regem por critérios de verdade ou de adequação gramatical, mas de efetividade estética, cultural, ideológica."134

\begin{tabular}{|c|c|c|}
\hline Minutagem & Fala do personagem & Tradução/Legenda \\
\hline $26: 30$ & $\begin{array}{l}\text { Quincas [morto]: Minha } \\
\text { espanholita do fiofó de } \\
\text { castanhola. }\end{array}$ & $\begin{array}{l}\text { Quincas [dead]: I miss my } \\
\text { Spanish floozy/with her bum of } \\
\text { castanets. }\end{array}$ \\
\hline
\end{tabular}

Aqui há outra menção sexual, dessa vez sutilmente aumentada com a adição do substantivo floozy ${ }^{135}$, acréscimo esse que pode ter compensado a falta de um termo específico para 'fiofó', que sugere mais o ânus que bum (traseiro).

\begin{tabular}{|l|l|l|}
\hline Minutagem & Fala do personagem & Tradução/Legenda \\
\hline
\end{tabular}

\footnotetext{
134 “....la traducción de los episodios amorosos o de las sugerencias sexuales no se rigen por criterios de verdad o de adecuación gramatical, sino de efectividad estética, cultural, ideológica."

${ }^{135}$ Segundo o www.urbandictionary.com, floozy é uma mulher de moral sexual questionável ou mulher promíscua.
} 


\begin{tabular}{|l|l|l|}
\hline 28:40 & $\begin{array}{l}\text { Quincas [morto]: Pelo } \\
\text { rumo da campainha, essa velha } \\
\text { já queimou a rosquinha. }\end{array}$ & $\begin{array}{l}\text { Quincas [dead]: By the } \\
\text { rhythm in her rumba,/she sat on a } \\
\text { cucumber! }\end{array}$ \\
\hline
\end{tabular}

Mais uma vez há uma alusão sexual que foi traduzida usando a estratégia descrita por Gottlieb como deslocamento, que seria buscar uma expressão que produzisse o mesmo efeito na língua alvo. As duas expressões foram eficazmente substituídas (rumo da campainha $=$ rhythm of her rumba e queimou a rosquinha $=$ sat on a cucumber) e o efeito cômico transparece.

\begin{tabular}{|c|c|c|}
\hline Minutagem & Fala do personagem & Tradução/Legenda \\
\hline $29: 20$ & $\begin{array}{l}\text { Curió: Choram as putas } \\
\text { da Bahia } \\
\text { Bundas em desespero a } \\
\text { soluçar } \\
\text { Contigo, ó sultão dos } \\
\text { mares e da maresia } \\
\text { Foi a noite levando a lua } \\
\text { e nossa alegria } \\
\text { Ó Quincas, paizinho } \\
\text { querido... } \\
\text { Sem você, nós perdeu o } \\
\text { abrigo. }\end{array}$ & $\begin{array}{l}\text { Curie: Weep! Bahia's } \\
\text { harlots fair... } \\
\text { Backsides weeping in } \\
\text { despair. } \\
\text { With you, O Sheik/of tides } \\
\text { and watery shore... } \\
\text { Night's robbed the } \\
\text { moon,/our joy's no more! } \\
\text { Oh Quincas,/our dearest } \\
\text { little Father... we've } \\
\text { without you, } \\
\text { gone/and lost our only shelter! }\end{array}$ \\
\hline
\end{tabular}

Nesse trecho, o personagem Curió lê um poema escrito por ele para homenagear o morto. A tradução fez uso de paráfrases, condensações e acréscimos (harlots fair/ our joy no more) para igualar a rima do original. A última legenda poderia ter sido dividida de forma diferente para ser uma leitura mais agradável (without you, we've gone and lost/our only shelter). 


\begin{tabular}{|l|c|c|}
\hline Minutagem & Fala do personagem & Tradução/Legenda \\
\hline $37: 53$ & Quincas [morto]: Agora & Quincas [dead]: Now, the \\
& a jurupoca vai piar! & shit'll hit the fan! \\
\hline
\end{tabular}

O regionalismo da expressão ‘agora a jurupoca vai piar' é muito específico e não teria um similar na língua alvo. A tradução por the shit'll hit the fan é praticamente uma substituição total, com uma transposição de sentido, pois a expressão em inglês não tem conotação sexual, que pode ser subentendida na expressão em português. ${ }^{136}$ Há, então, um abrandamento da expressão original; "o eufemismo e a ironia são formas de transgredir as regras linguístico-sociais, de dizer e não dizer"137 (SANTAEMILIA, 2010, p. 135)

\begin{tabular}{|l|l|l|l|}
\hline Minutagem & \multicolumn{1}{|c|}{ Fala do personagem } & \multicolumn{3}{|c|}{ Tradução/Legenda } \\
\hline $49: 15$ & \multicolumn{1}{|c|}{ Curió: Fique quieta que } & \multicolumn{1}{c|}{ Curie: Gonna be a god } \\
& $\begin{array}{l}\text { daqui a pouco você vai virar } \\
\text { quitute de orixá. }\end{array}$ & snack. & \\
\hline
\end{tabular}

A tradução desse pequeno trecho fez uma redução extensiva, uma dizimação, estratégia explicitada por Gottlieb quando há perda de conteúdo semântico ou estilítico. Tal estratégia, segundo Panek (2009, p. 45), diminui o esforço de compreensão do espectador, mas “pode ser considerada inaceitável, já que o texto traduzido não é tão engraçado quanto o original.",138

\begin{tabular}{|c|c|c|}
\hline Minutagem & Fala do personagem & Tradução/Legenda \\
\hline $1: 01: 45$ & Quincas [morto]: $\mathrm{O}$ & Quincas [dead]: The Orix \\
\hline
\end{tabular}

\footnotetext{
${ }^{136}$ Jurupoca (ou jerupoca; jiripoca) é um peixe de água doce que tem a mandíbula projetada para a frente. Costuma nadar na superfície da água e emitir um som semelhante ao pio de um pássaro, o que fez surgir a expressão "hoje a jiripoca vai piar" que, popularmente, se refere a sexo; algo como "hoje a coisa vai ser quente" ou "hoje o pau vai comer".

137 "El eufemismo y la ironía son formas de transgredir las reglas lingüístico-sociales, de decir y no decir."

138 "...it can be found unacceptable, as the translated text is not as funny as the original."
} 


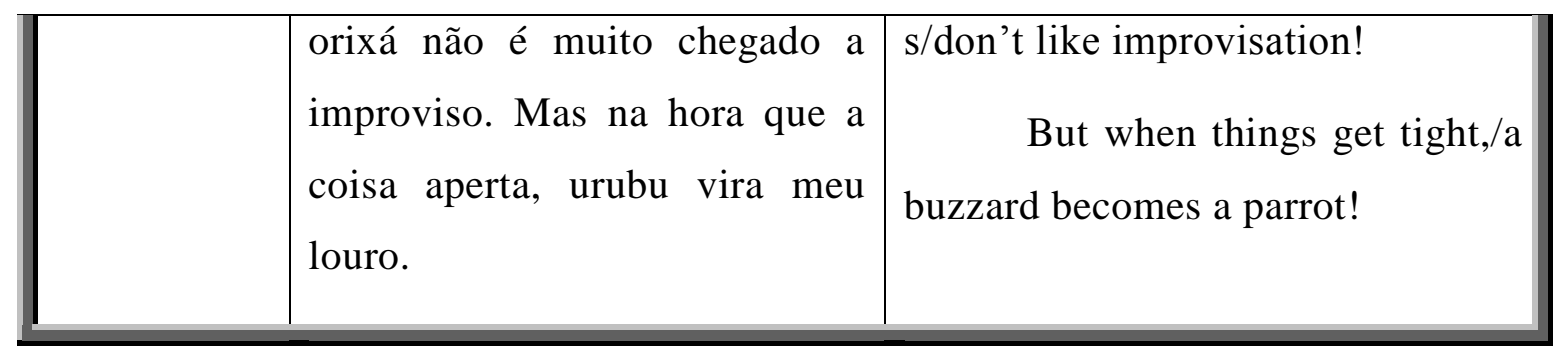

Nesse trecho, houve uma tradução literal, a mesma associação foi feita, sugerindo uma convergência do sistema linguístico e do estilo. Ainda que a piada não seja imediatamente [re]conhecida pelo espectador, a ideia traz em si a carga humorística. Mais uma vez parece ter havido uma falha no uso dos acentos, pois Orixá perdeu o "a" acentuado; provavelmente, uma falha técnica durante o processo de legendagem.

\begin{tabular}{|l|l|l|l|}
\hline Minutagem & \multicolumn{4}{|c|}{ Fala do personagem } & \multicolumn{2}{|c|}{ Tradução/Legenda } \\
\hline 1:03:20 & Leonardo: Ave Maria, & \multicolumn{1}{l|}{ Leonardo: It gave me a } \\
& $\begin{array}{l}\text { me deu um susto você lá } \\
\text { conversando com aquela } \\
\text { macumbeira. }\end{array}$ & Voodoo to see you/talking to that \\
& & & \\
\hline
\end{tabular}

A tradução para a legenda deletou o vocativo (Ave Maria) e fez um neologismo que, de certa forma, 'pejorativou' o termo macumbeira. Segundo Panek (2009, p. 51), “a falta de elementos correspondentes entre duas línguas implica em soluções inovadoras" ${ }^{\prime 139}$. O legendador preferiu não manter a palavra como decalque, mas fazer uma adaptação.

\begin{tabular}{|l|c|cc|}
\hline Minutagem & Fala do personagem & \multicolumn{3}{|c|}{ Tradução/Legenda } \\
\hline $1: 16: 19$ & Homem: Todo guerreiro & Man: Every blade has a \\
& tem seu dia de pururuca. & blunt day. & \\
& & & \\
\hline
\end{tabular}

139 "the lack of corresponding elements between two languages entails novel solutions." 
Esse trecho foi destacado por apresentar uma utilização eficaz da estratégia de substituição, com a "transferência do nível de formalidade ou informalidade do elemento fonte" ${ }^{140}$ (PANEK, 2009, p. 48). Há uma orientação 'domesticadora' que mantém a informalidade do original e ainda há uma referência à blade (lâmina; espada) que remete a 'guerreiro'.

\begin{tabular}{|l|c|c|}
\hline Minutagem & Fala do personagem & Tradução/Legenda \\
\hline $1: 18: 40$ & Quincas [morto]: O & $\begin{array}{c}\text { Quincas [dead]: Gene Kelly } \\
\end{array}$ \\
& $\begin{array}{l}\text { Gene Kelly do Pelourinho, } \\
\text { dançando no meio da putaria. }\end{array}$ & of Pillory Hill,/living the high-life! \\
\hline
\end{tabular}

Pode-se dizer que, nesse trecho, exceto pela manutenção do nome - bastante conhecido na maioria das culturas - Gene Kelly, houve um abrandamento dos elementos da linguagem mais sensível (putaria) mas, como o termo aqui é empregado de forma genérica, a tradução conseguiu realçar a ideia de uma vida 'desregrada'. A tradução de Pelourinho por Pillory Hill (que é uma localidade na Inglaterra) foi uma substituição que não parece ter sido apropriada; a imitação/decalque funcionaria melhor, já que Pelourinho parece ser uma referência mais conhecida que Pillory Hill.

\begin{tabular}{|c|c|c|}
\hline Minutagem & Fala do personagem & Tradução/Legenda \\
\hline $1: 19: 19$ & $\begin{array}{l}\text { Quincas [morto]: Quem } \\
\text { diz que tudo tem seu lado bom, } \\
\text { é porque ainda não teve dor de } \\
\text { dente, hemorróida, ou não } \\
\text { conheceu Miguel Charuto. } \\
\text { Miguel era o cão chupando } \\
\text { manga. }\end{array}$ & $\begin{array}{l}\text { Quincas [dead]: Whoever } \\
\text { says everything/in life has a good } \\
\text { side... } \\
\text { hasn't } \\
\text { toothach,/hemoroides... } \\
\text { or met Cigar Joe. } \\
\text { Joe was an ape sucking on } \\
\text { lemons. }\end{array}$ \\
\hline
\end{tabular}

140 “...to transfer the 'level of formality or informality' of the source element." 
A tradução de Miguel Charuto por Cigar Joe é um exemplo de modulação/substituição que funciona porque a informação principal - o charuto permanece; e Miguel é quase tão genérico quanto Joe. A referência humorística/irônica do 'cão chupando manga' (uma pessoa muito feia, horrenda) é mantida na substituição por 'ape sucking on lemons', ainda que a ideia de 'suck on lemons' tenha mais a ver com o humor - ou mau humor - da pessoa. A referência pode ser tanto a uma pessoa feia como a uma pessoa amarga. De qualquer maneira, o referencial imagético leva a crer que um gorila chupando limões não deve ser uma visão muito bela.

\begin{tabular}{|c|c|c|}
\hline Minutagem & Fala do personagem & Tradução/Legenda \\
\hline $1: 34: 56$ & $\begin{array}{l}\text { Quincas [morto]: Cada } \\
\text { qual que cuide de seu enterro. } \\
\text { Impossível, não há. } \\
\text { Sete palmos de terra não } \\
\text { vão me incarcerar. Vagueio no } \\
\text { sabor das ondas, num leito de } \\
\text { espuma do mar. } \\
\text { Nem no céu, nem no } \\
\text { inferno. No mar é que eu vou } \\
\text { morar. } \\
\text { Esperando Manuela, no } \\
\text { colo de Iemanjá. } \\
\text { Tristeza não paga dívida, } \\
\text { é ditado bem conhecido. } \\
\text { caixão tem que chorar a } \\
\text { morte guem morreu sem ter } \\
\text { vivido. }\end{array}$ & $\begin{array}{l}\text { Quincas [dead]:Each can } \\
\text { choose/the way he'll go. } \\
\text { Nothing's impossible,/if } \\
\text { you know how. } \\
\text { Six feet of soil... } \\
\text { won't be my home... } \\
\text { I'll float the waves... } \\
\text { on beds of foam. } \\
\text { Not in heaven or hell./In the } \\
\text { sea I'll rest... } \\
\text { To await Manuela,/on } \\
\text { Iamanj's breast. } \\
\text { They say that/"sorrow } \\
\text { I'll not go down/to an } \\
\text { make more room... } \\
\text { Wout way the debt"... } \\
\text { death,/hasn't lived as yet. } \\
\text { you can save my coffin/to } \\
\text { weeps at }\end{array}$ \\
\hline
\end{tabular}




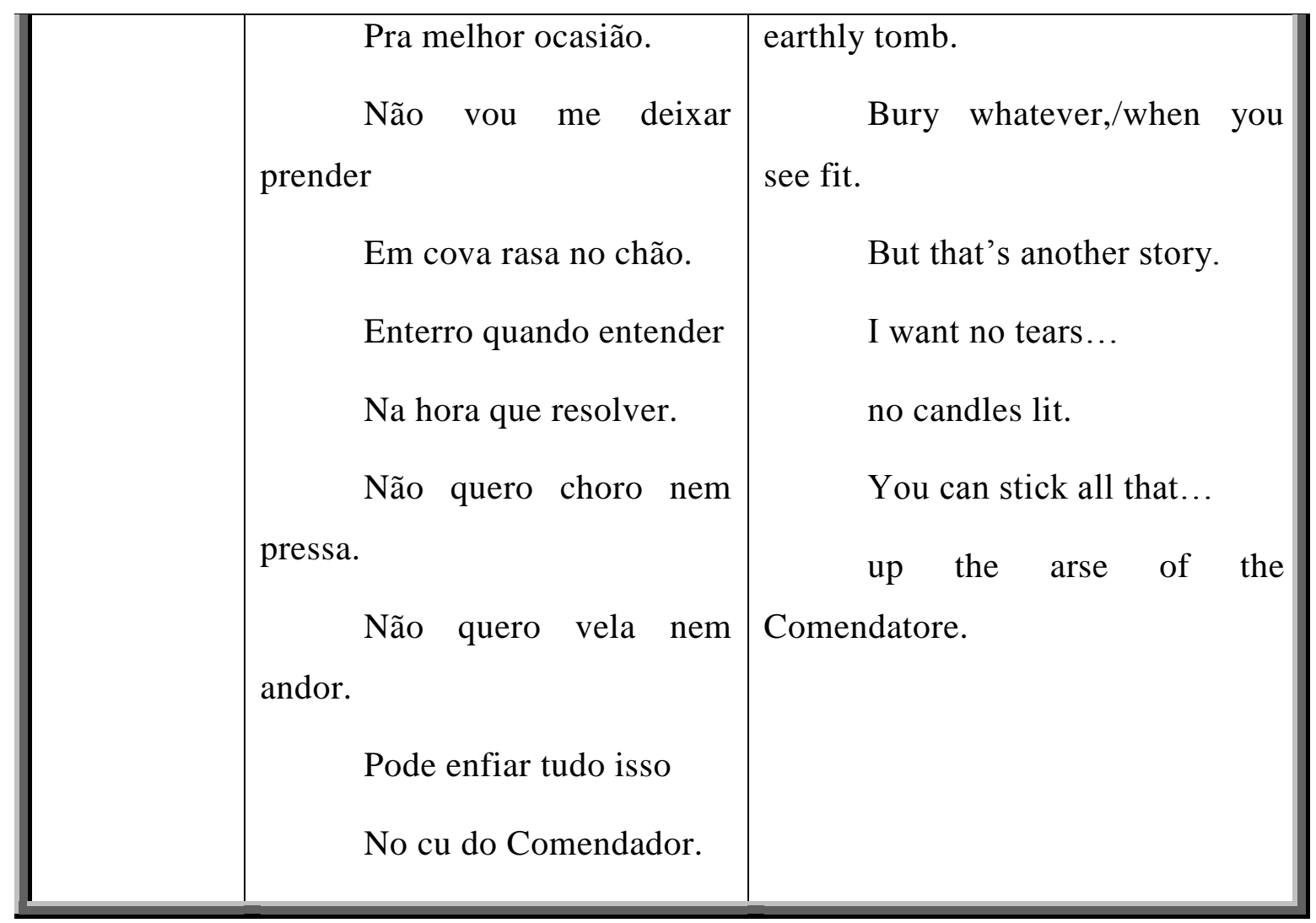

Os versos finais do filme Quincas Berro D’Água começam em tom melancólico e sorumbático para terminar em apoteótico xingamento, que quebra as expectativas construídas ao longo do monólogo e aciona o riso, catártico até, pois dá um toque de humor a um tema - a morte - que, apesar de não estar dentro do espectro de linguagem considerada sensível, é um tabu em muitas culturas. Brincar com ela é, muitas vezes, a forma de lidar com a ideia. Todo o filme é uma zombaria com a ideia da morte, e há muitos eufemismos e substituições na legenda pois, segundo GAO (2013, p. 2313), “palavras e expressões eufemísticas possibilitam que falemos coisas desagradáveis e neutralizemos os aborrecimentos". ${ }^{141}$

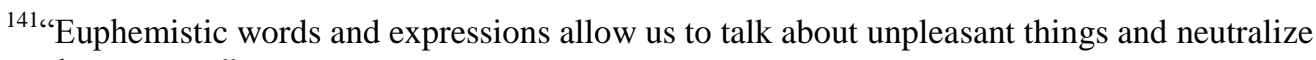
unpleasantness."
} 


\subsection{O Auto da Compadecida - A Dog's Will}

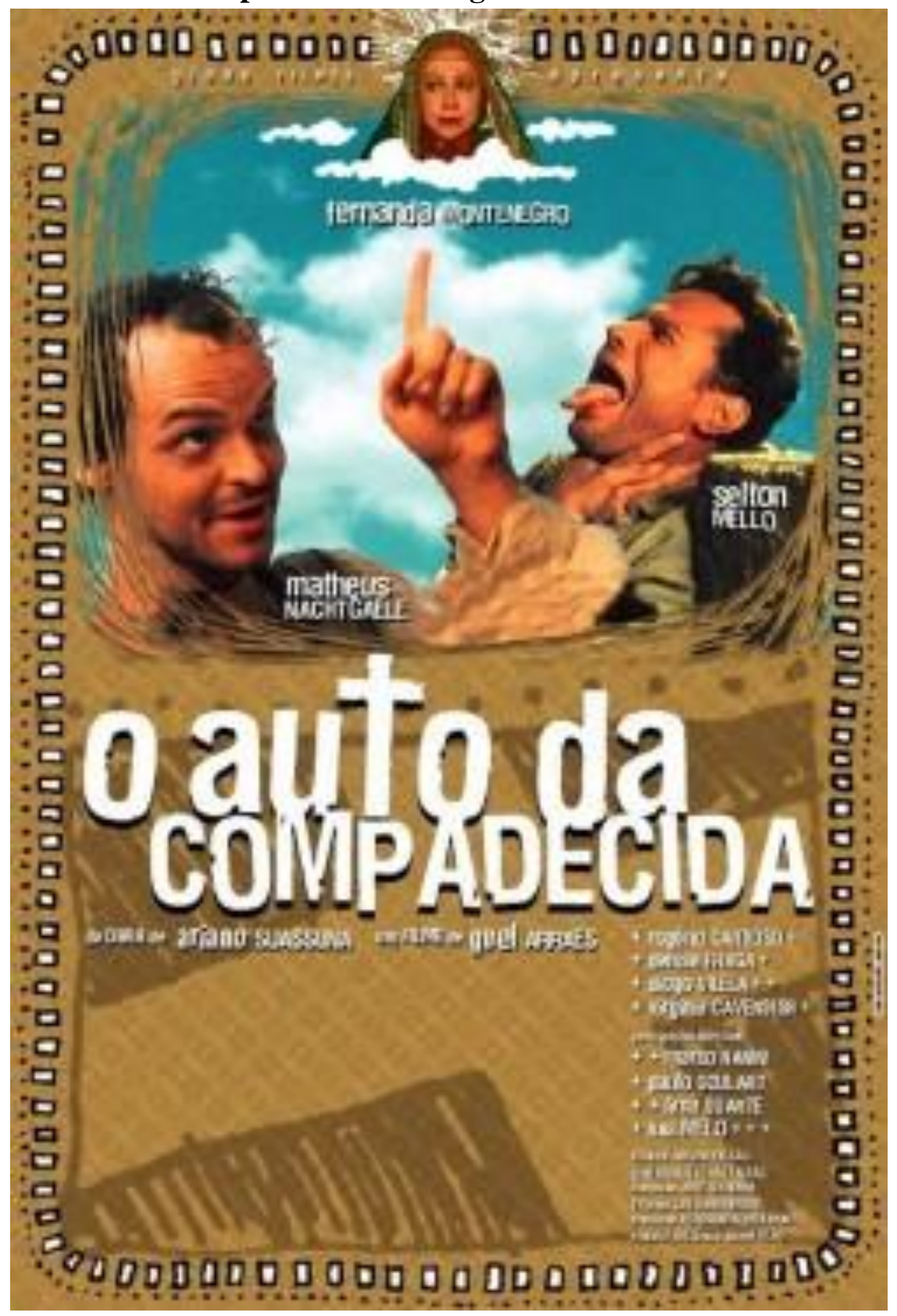

Figura 8. Capa do DVD do filme $O$ auto da Compadecida.

O Auto da Compadecida é um filme brasileiro de comédia e drama lançado em 1999. Dirigido por Guel Arraes e com roteiro de Adriana Falcão, o filme é baseado na peça teatral "Auto da Compadecida" de 1955 de Ariano Suassuna, com elementos de $O$ Santo e a Porca e Torturas de um Coração, ambas do mesmo autor, e influências do clássico de Giovanni Boccaccio Decameron. O filme recebeu durante o Grande Prêmio Cinema Brasil, evento criado pelo Ministério da Cultura, as premiações de melhor diretor, melhor roteiro, melhor lançamento e melhor ator. 
As filmagens do filme foram feitas em 1999 na cidade de Cabaceiras, interior do estado da Paraíba, conhecida por ser palco de vários outros filmes brasileiros, com parceria de produção entre a Globo Filmes e a Lereby Produções. Estreou em 10 de setembro de 1999, no Brasil, e foi exibido em outros países em eventos de cinema e em mídia para distribuição. Nos Estados Unidos, o filme foi renomeado como A Dog's Will. Foi recebido com críticas positivas na maioria dos países da América do Sul.

As legendas são brancas com bordas pretas, seguindo o padrão de legendas para DVD. Estão centralizadas na parte inferior da tela, e a leitura é fácil e fluida.

O filme é bem regionalista, sendo a tradição nordestina claramente identificada - ainda que um pouco 'modernizada' - nas festas típicas, nas referências ao cangaço e na figura do sertanejo que, segundo Darcy Ribeiro (apud MOREIRA, 2013, p. 7), é retratado

por sua religiosidade singela tendente ao messianismo fanático, por seu carrancismo de hábitos, por seu laconismo e rusticidade, por sua predisposição ao sacrifício e à violência. E, ainda, pelas qualidades morais características das formações pastoris do mundo inteiro, como o culto da honra pessoal, o brio e a fidelidade à suas chefaturas.

\begin{tabular}{|c|c|c|}
\hline Minutagem & Fala do personagem & Tradução/Legenda \\
\hline $02: 51$ & $\begin{array}{l}\text { João: Já leram para mim } \\
\text { um folheto que reza mais que } \\
60 \text { qualidades de corno. } \\
\text { Chicó: Nossa! Tem mais } \\
\text { corno que passarinho! } \\
\text { João:Tem corno pro } \\
\text { alfabeto todo, desde o } \\
\text { apressado, que é corno antes } \\
\text { mesmo de casar, até o zeloso, } \\
\text { que só gosta de ver a mulher } \\
\text { bem vestida. }\end{array}$ & $\begin{array}{l}\text { Jack: There are more } \\
\text { than/60 types of cuckolds. } \\
\text { Chicó: Wow! That's } \\
\text { more/than there are birds! } \\
\text { Jack: The "hasty" type } \\
\text { is/cuckolded before marriage... } \\
\text { and the "careful" type/likes } \\
\text { his wife well-dressed! }\end{array}$ \\
\hline
\end{tabular}


Nesse trecho, logo no início do filme, os protagonistas são apresentados como dois nordestinos nômades, procurando emprego. Nessa legenda, houve uma omissão de informação (pro alfabeto todo), pois na fala original o personagem cita exemplos com "A" e "Z" e a tradução não seguiu a linha; a solução foi omitir toda a frase relativa ao alfabeto. Houve também omissão no início, sobre o 'folheto' que leram para o João; a tradução foi bem mais direta e brusca.

\begin{tabular}{|c|c|c|}
\hline Minutagem & Fala do personagem & Tradução/Legenda \\
\hline 11:09 & $\begin{array}{l}\text { Padre: Já está fedendo? } \\
\text { Major } \\
\text { Fedendo? Quem? } \\
\text { Padre: A bichinha. } \\
\text { Major Moraes: Não! } \\
\text { Mas o que que o senhor quer } \\
\text { dizer? } \\
\text { Padre: Nada, desculpe, é } \\
\text { só mesmo um modo de falar. } \\
\text { Major: Pois o senhor } \\
\text { anda com um modo de falar } \\
\text { muito esquisito. } \\
\text { Padre: Desculpe um } \\
\text { pobre padre sem instrução. } \\
\text { Qual é a doença, major? } \\
\text { Rabuge? }\end{array}$ & $\begin{array}{l}\text { Priest: -Does it stink yet? } \\
\text { Major Moraes: -Stink? } \\
\text { What? } \\
\text { Priest: -Your little one. } \\
\text { Major: No! } \\
\text { Major: -What do you mean } \\
\text { by that? } \\
\text { Priest: -Nothing. Manner of } \\
\text { speaking. } \\
\text { Major: Well, this manner/of } \\
\text { yours is very odd. } \\
\text { Priest: } \\
\text { and/spread to her whole body. } \\
\text { Major: On her "tail"? } \\
\text { old,/ignorant priest. } \\
\text { Priest: -What ails her? The } \\
\text { Priest: Yes. I've seen one } \\
\text { mange? }\end{array}$ \\
\hline
\end{tabular}




\begin{tabular}{|c|c|}
\hline 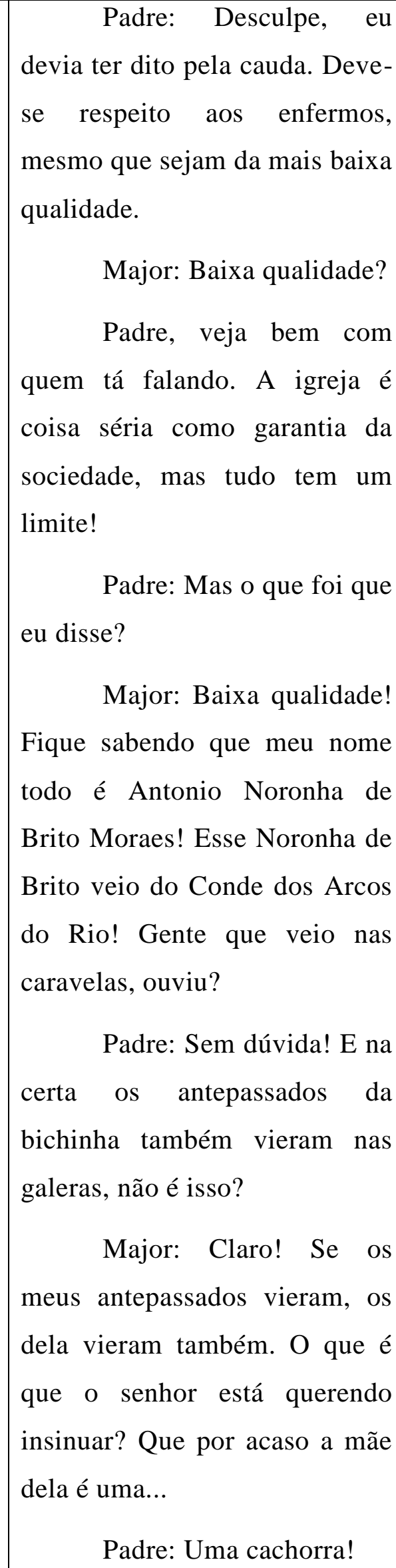 & 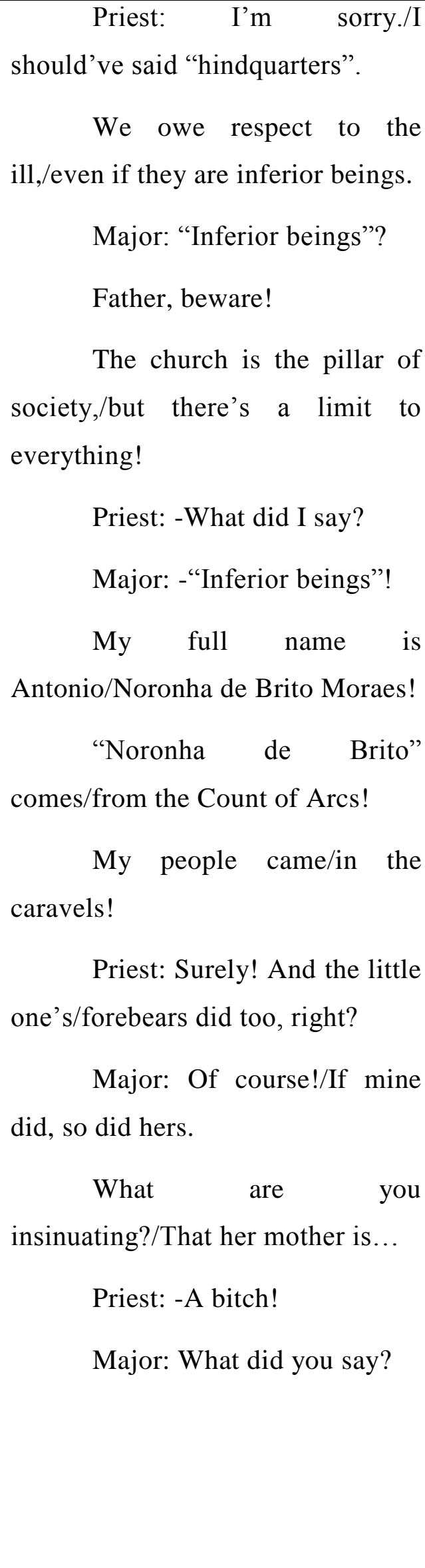 \\
\hline
\end{tabular}




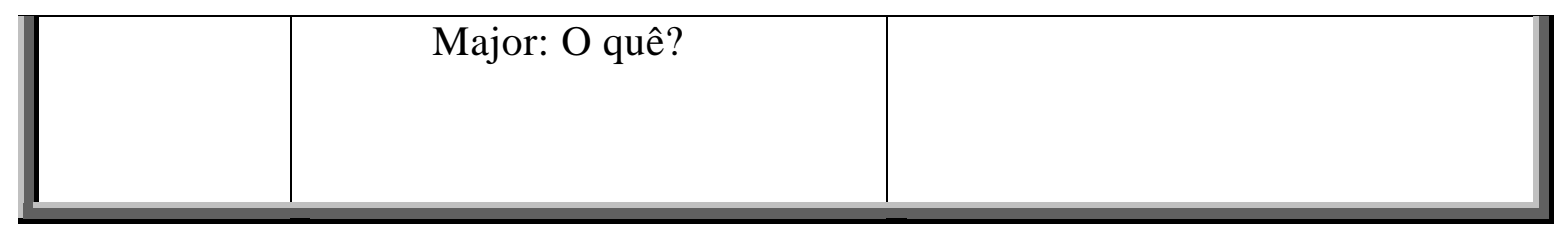

Este trecho, bastante longo, foi quase todo traduzido literalmente, e o toque de humor e ironia foi mantido pois o humor resulta da confusão criada anteriormente (o major fala de sua filha e o padre acha que ele está falando de sua cachorra). Mais uma vez, a tríade imagem-som-legenda funciona em sintonia para criar o efeito desejado. A entonação dos personagens acrescenta ao tom humorístico e a ambiguidade do diálogo gera a incongruência, ingrediente principal do humor. Como diz Ridd (1996, p. 476), “a legenda é um elemento a mais na estética do filme ou vídeo", e aqui funcionaram com precisão para transmitir todo o colorido espirituoso do diálogo.

\begin{tabular}{|c|c|c|}
\hline Minutagem & Fala do personagem & Tradução/Legenda \\
\hline $21: 25$ & $\begin{array}{l}\text { João Grilo: Muito pior é } \\
\text { enterrar a cachorra em latim, } \\
\text { como se fosse cristã, e nem por } \\
\text { isso eu vou chamá-lo de safado. } \\
\text { Bispo: O que é isso? } \\
\text { Padre: Uma dor que me } \\
\text { deu assim de repente. } \\
\text { João Grilo: Coitado! } \\
\text { Mais o senhor tinha que ver era } \\
\text { o grito que minha patroa dava } \\
\text { enquanto se fazia o enterro da } \\
\text { cachorra. } \\
\text { Padre: João Grilo, meu } \\
\text { querido, me acuda, por favor! } \\
\text { João Grilo: Eu? Quem }\end{array}$ & $\begin{array}{l}\text { Jack the Cricket: It's much } \\
\text { worse to bury a bitch in/Latin, in a } \\
\text { Christian funeral... } \\
\text { and even then I } \\
\text { wouldn't/call you a rascal! } \\
\text { Bishop: -What's wrong? } \\
\text { Priest: -Suddenly, I'm in } \\
\text { pain! } \\
\text { Jack: Poor Father! But you } \\
\text { should have/heard my mistress at } \\
\text { the funeral. } \\
\text { Priest: Help me, Jack the } \\
\text { Cricket,/dear friend, I'm dying! } \\
\text { Jack: Me? Who am I to help } \\
\text { a priest?/I'm nothing but a rascal! }\end{array}$ \\
\hline
\end{tabular}




\begin{tabular}{|c|c|}
\hline $\begin{array}{l}\text { sou eu pra socorrer padre? Eu, } \\
\text { um amarelo muito safado! } \\
\text { Padre: Eu retiro o que } \\
\text { disse, João. } \\
\text { João: Retirando ou não } \\
\text { retirando, o fato é que a } \\
\text { cachorra enterrou-se em latim. } \\
\text { Bispo: Cachorra? } \\
\text { Enterrada em latim? } \\
\text { Padre: Enterrada } \\
\text { latindo, senhor Bispo. "Au-au- } \\
\text { au-au”, num sabe? } \\
\text { Bispo: Não sei, não } \\
\text { senhor. E nunca vi cachorra } \\
\text { morta latir. }\end{array}$ & $\begin{array}{l}\text { Priest: -I take it back! } \\
\text { Jack: -Take it back... } \\
\text {...but the bitch was buried } \\
\text { in Latin. } \\
\text { Bishop: -A bitch? Buried in } \\
\text { Latin? } \\
\text { Priest: He means it was } \\
\text { barking./'Bowwow", you know? } \\
\text { Bishop: No, I don't. I've } \\
\text { never/seen a dead dog bark. }\end{array}$ \\
\hline
\end{tabular}

Mais uma vez, quase todo o trecho foi traduzido literalmente, com pequenas modificações para adequação ao espaço da legenda. No final, o jogo de palavras (latim x latir), que no original criou o efeito cômico, ficou prejudicado na tradução, pois não houve o mesmo jogo que produza o mesmo efeito sonoro. Como comenta Possenti (1998, p. 43),

só há aparentemente um tipo de piada que não pode ser repetida, ou que não é transcultural: as que dependem estritamente de fatores linguísticos e, portanto, só podem funcionar no interior de uma língua ou de línguas estreitamente aparentadas.

Ainda assim, a frase final do bispo é eficiente para aquecer o gatilho de humor.

\begin{tabular}{|c|c|c|}
\hline Minutagem & Fala do personagem & Tradução/Legenda \\
\hline $23: 45$ & $\begin{array}{l}\text { Chicó: } \\
\text { senhora? Já }\end{array}$ & $\begin{array}{l}\text { Chicó: -How are you? Do } \\
\text { you feel better? }\end{array}$ \\
\hline
\end{tabular}




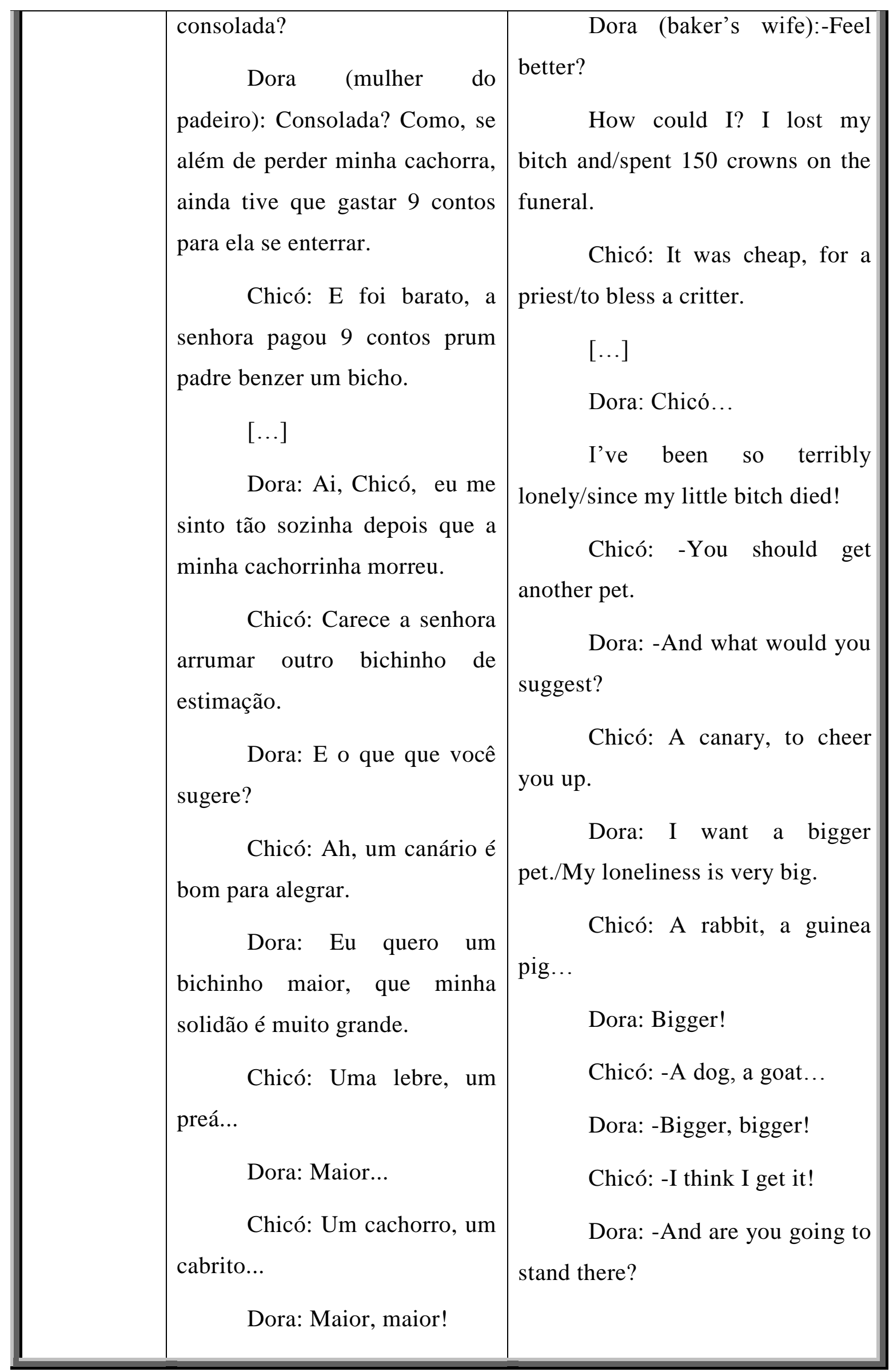




\begin{tabular}{|l|l|l|}
\hline \multicolumn{1}{|c|}{ Chicó: Parece que eu tô } \\
entendendo... \\
aí, é?
\end{tabular} \mid

A alusão sexual aqui é bastante óbvia, ainda que não explícita. Segundo Santaemilia (2005, p. 4), “a linguagem sexual é um discurso muito mais abrangente. Podemos verificar uma presença esmagadora de sexo em nossa vida cotidiana - em nossas palavras, em nossos textos, em nossas projeções simbólicas." No trecho acima, o enunciado é engraçado porque garante a dupla interpretação, e essa alusão sexual tem um irresistível toque de humor, o que remete a Possenti, que afirma que o modelo das piadas permanece, com as mudanças de referências; os tópicos, temas e estereótipos são basicamente os mesmos.

[...] apesar de culturalmente diferidos, os povos riem das mesmas coisas. $\mathrm{O}$ enunciado humorístico é resultado da interação social e surge muitas vezes da observação do diferente, daquilo que causa estranheza, da esperteza alheia. É a forma encontrada para criticar atitudes, para dar voz ao que não pode ser dito. $\mathrm{O}$ homem produz e consome o cômico a partir da sua própria natureza falha e crítica. (MOREIRA, 2013, p. 5)

\begin{tabular}{|l|l|c|c|}
\hline Minutagem & Fala do personagem & \multicolumn{2}{|c|}{ Tradução/Legenda } \\
\hline $51: 45$ & Chicó: Mas quedê & Chicó: Where's Jack the \\
& $\begin{array}{l}\text { aquele João Grilo, o quengo } \\
\text { mais fino do nordeste? Capaz } \\
\text { de fazer dormindo o que } \\
\text { ninguém faz acordado? }\end{array}$ & Cricket,/the sharpest mind of all... \\
\end{tabular}

Todas as referências regionais foram omitidas nesse trecho, possivelmente pelo limite das legendas ou pela ausência de um equivalente que não necessitasse de expansão. Além disso, houve uma transposição e substituição que talvez tenha causado um certo conflito entre o que foi dito e o que o espectador leu na legenda (capaz de fazer dormindo o que ninguém faz acordado $\mathrm{x}$ the smartest and boldest even in his sleep). Uma tradução que fizesse a mesma oposição entre ‘dormindo' e 
'acordado' talvez fosse mais eficaz para transmitir a mensagem, já que a legenda é, no dizer de Moreira (2013, p. 3), "uma síntese da fala de cada personagem."

\begin{tabular}{|l|r|r|}
\hline Minutagem & Fala do personagem & Tradução/Legenda \\
\hline $54: 20$ & Chicó: Comigo é assim, & Chicó: I'll show them a \\
& escreveu, não leu, o pau comeu. & thing or two! \\
\hline
\end{tabular}

Esse trecho foi selecionado por ser um exemplo de deslocamento que é eficaz mas o efeito cômico não transparece. A expressão na língua fonte é bem tradicional do falar regionalista/nacional, e a expressão traduzida também é corriqueira na língua alvo. Panek (2009) se concentra no esforço de processamento do receptor. Aqui, a tradução não causa esforço no espectador, e a imagem que acompanha o som é o que caracteriza o cômico - e o irônico, pois o personagem não é nada corajoso da situação.

\begin{tabular}{|l|l|l|}
\hline Minutagem & \multicolumn{1}{|c|}{ Fala do personagem } & \multicolumn{2}{|c|}{ Tradução/Legenda } \\
\hline $1: 10: 18$ & \multicolumn{1}{|c|}{ Diabo: Estão vendo? O } & \multicolumn{1}{c|}{ Devil: See? The devil } \\
& $\begin{array}{l}\text { diabo não é tão feio quanto } \\
\text { parece. }\end{array}$ & isn't/as ugly as they say. \\
\hline
\end{tabular}

Aqui também o curto trecho foi escolhido para evidenciar uma tradução literal que não afeta negativamente o esforço de processamento e, combinada à imagem, provoca uma reação de riso espontâneo, pela incongruência entre imagem e texto.

\begin{tabular}{|l|l|c|}
\hline Minutagem & \multicolumn{1}{|c|}{ Fala do personagem } & Tradução/Legenda \\
\hline $1: 26: 15$ & \multicolumn{1}{|c|}{ Diabo: Ah, não tem } & Devil: There's no hope! \\
& $\begin{array}{l}\text { jeito! Homem que mulher } \\
\text { governa... }\end{array}$ & $\begin{array}{l}\text { It's always like that when/a } \\
\text { woman rules over a man! }\end{array}$ \\
\hline
\end{tabular}


O trecho acima mostra uma fala do diabo fazendo referência a Jesus e Maria. A estratégia usada foi a explicitação ou expansão (It's always like that...) que tem efeito de explicar/detalhar o sentido do que foi dito. É uma referência irônica e sexista e o legendador escolheu acrescentar informações para enfatizar a ironia. "Na verdade, o processo de criação das legendas resulta da leitura, da interpretação e das escolhas do legendista, no momento de fazer a sua tradução" (MOREIRA, 2013, p. 3). Aqui a legenda apresenta uma falha técnica de divisão, o que pode dificultar a leitura e compreensão mais fluida do texto.

\begin{tabular}{|l|l|l|}
\hline Minutagem & Fala do personagem & Tradução/Legenda \\
\hline $1: 29: 29$ & Jesus: Mãe, se a senhora & \multicolumn{1}{|c|}{ Jesus: Mother, if you go on } \\
& $\begin{array}{l}\text { continuar a interceder desse } \\
\text { jeito por todos, o inferno vai } \\
\text { terminar virando uma } \\
\text { repartição pública... Existe, mas } \\
\text { não funciona. }\end{array}$ & $\begin{array}{c}\text { hell's going to be like/a } \\
\text { government agency... }\end{array}$ \\
\hline
\end{tabular}

A referência irônica foi também traduzida literalmente, uma transferência que manteve o tom sarcástico para gerar o riso. Espera-se que o espectador tenha essa referência da suposta incompetência ou imperícia dos funcionários de repartições públicas; assim, a tradução é eficiente e alcança - ou até intensifica - o efeito humorístico.

De maneira geral, as estratégias utilizadas nas legendas do filme, ainda que inconscientemente, pois o tradutor/legendador pensa em soluções, mais que em estratégias intermediárias, foram, em grande parte, estratégias eficazes de tradução literal ou de explicitação/explicação. No entanto, o conhecimento das estratégias é de extrema importância para que o efeito pretendido pela fala seja consistente e coerentemente transferidos para a legenda. Segundo Panek (2009, p. 53), “o uso 
adequado dessas técnicas pode facilitar a compreensão do humor e a chegada do espectador à interpretação pretendida."142

142 "a reasonable use of these techniques can ease humor comprehension and the target audience's arrival at the intended interpretation. 


\subsection{Cine Holliúdy}

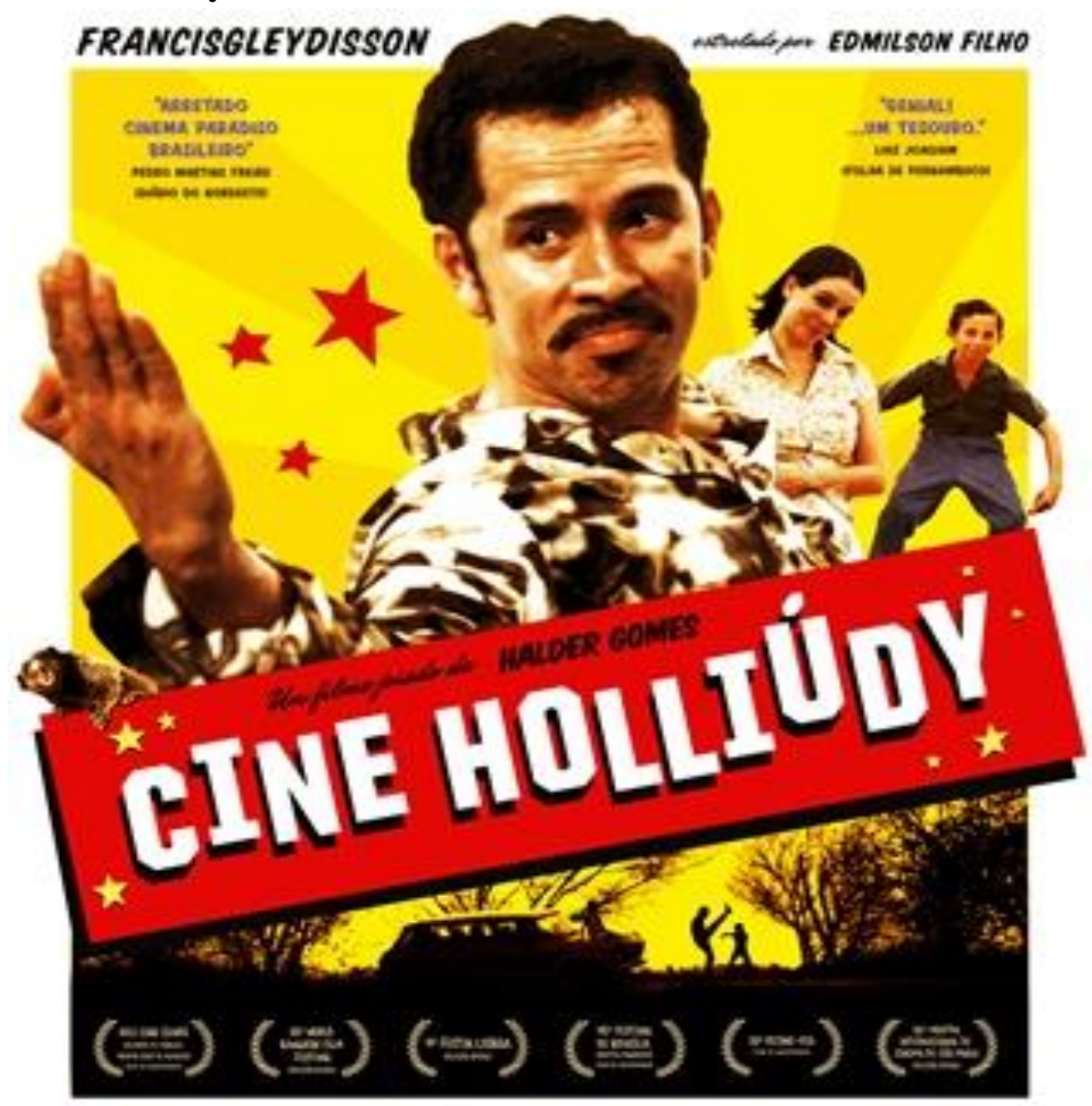

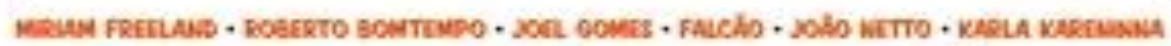

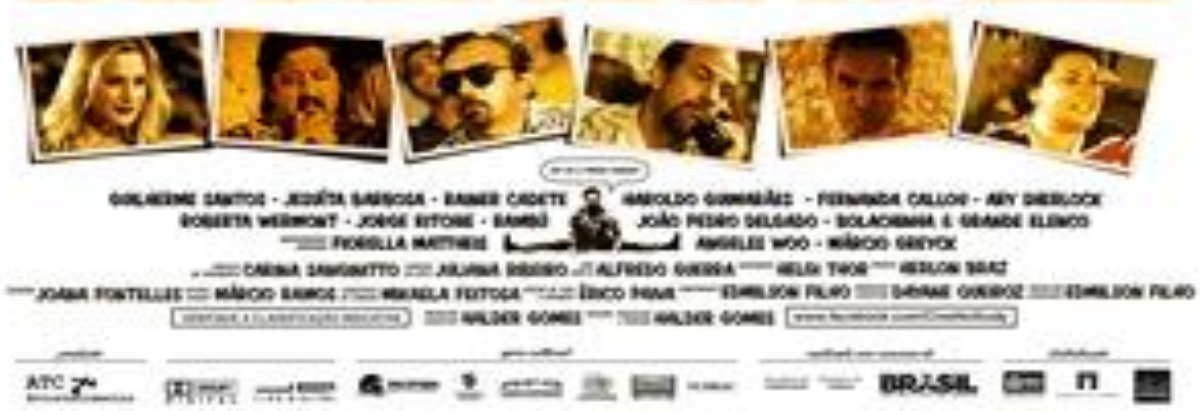

Figura 9. Capa do DVD do filme Cine Holliúdy.

Cine Holliúdy é um filme de comédia brasileiro de 2013, dirigido por Halder Gomes e estrelado por Edmilson Filho, Miriam Freeland e Roberto Bomtempo. O filme foi o primeiro no edital de longa-metragens de baixo orçamento do Ministério da Cultura do Brasil em 2009, sendo uma versão em longa-metragem do premiado curta Cine Holliúdy - O Astista Contra o Caba do Mal. Levou 481.203 espectadores ao cinema em 2013 e faturou 4,9 milhões de reais. 
O curta foi visto em 80 festivais de 20 países e ganhou 42 prêmios. "Nos festivais, os críticos me animaram e falaram que tinha que fazer um longa-metragem desse filme e, realmente, tinha muito material para isso", afirmou o diretor Halder. O longa foi lançado em 9 de agosto de 2013 em Fortaleza e em algumas cidades de sua região metropolitana.

\section{A história, segundo a descrição do DVD:}

Interior do Ceará, década de 1970. A popularização da TV permitiu que os habitantes da cidade desfrutassem de um bem até então desconhecido. Porém, o televisor afastou as pessoas dos cinemas. É aí que Francisgleydisson entra em ação. Ele é o proprietário do Cine Holiúdy, um pequeno cinema da cidade que terá a difícil missão de se manter vivo como opção de entretenimento.

As legendas são brancas com sombreado preto quase imperceptível e centralizadas no canto inferior da tela, seguindo os padrões utilizados para legendas no Brasil. A leitura é fácil e fluida, apesar de uns poucos erros gramaticais ao longo do filme.

Logo no início do filme - aos 3 segundos de reprodução - há o aviso: "Vocês vão assistir ao primeiro filme nacional falado em "Cearensês", por isso, as legendas". Com 1'20" de reprodução, apresenta-se o Certificado de Censura, traduzido como Censorship Certificate. As letras vão aparecendo na tela aos poucos, como numa máquina de escrever: Este filme contém cenas de Cearensidade explícita. A legendaque aparece no meio da tela antes do original em português, diz: This movie contains scenes/ Cearensidade make explicit. Talvez a intenção tenha sido a de fazer um chiste ou mostrar o tom de paródia desde o início, mas o efeito é negativo devido aos erros gramaticais. Segue-se a apresentação dos personagens, todos eles traduzidos; alguns adaptados, como demonstrado na sequência abaixo.

\begin{tabular}{|l|l|l|}
\hline Minutagem & Fala do personagem & Tradução/Legenda \\
\hline $03: 04$ & A Espilicute & The First Lady \\
& O Simiofóbico & The Apephobic \\
\hline
\end{tabular}




\begin{tabular}{|c|c|c|}
\hline & A Vanderléia (car) & The Dolly Parton \\
Kong Afilhado do King & King Kong's son in law \\
\hline
\end{tabular}

No início, ao apresentar os insanos personagens do filme, há uma série de adaptações que são extremamente eficazes; Barbosa (2007, p. 76) diz que "a adaptação é o limite extremo da tradução". Exceto a referência a King Kong, nenhuma outra se encaixa na realidade extralinguística da língua alvo; a estratégia foi bem empregada nesse trecho de apresentação.

\begin{tabular}{|l|c|c|}
\hline Minutagem & Fala do personagem & \multicolumn{2}{|c|}{ Tradução/Legenda } \\
\hline $10: 24$ & $\begin{array}{l}\text { Mãe de Valdisney: Eu } \\
\text { quero é que tu pegue uma } \\
\text { hérnia no pulmão, seu bibelô de } \\
\text { macumba! }\end{array}$ & $\begin{array}{c}\text { Valdisney's mother: Go } \\
\text { catch a lung hernia,/ you voodoo } \\
\text { toy. }\end{array}$ \\
& $\begin{array}{c}\text { Valdisney: Mãe, e a tevê } \\
\text { que a senhora ia comprar? } \\
\text { Mãe de Valdisney: }\end{array}$ & $\begin{array}{c}\text { Valdisney: And the color } \\
\text { Quando o Papa casar. }\end{array}$ \\
\hline
\end{tabular}

A primeira referência cômica aqui é o próprio nome do personagem, Valdisney (corruptela de Walt Disney); no entanto, essa referência só será explicitada mais tarde no filme, quando o personagem escreve seu nome. A tradução de macumba por voodoo pode ser uma menção sensível, pois fazer piada de cunho religioso pode gerar conflitos. Houve uma condensação na explicação do tipo de televisão que o menino queria e uma tradução literal que mostra que "o humor 
possui particularidades sociais, culturais, etárias e de gênero, mas carrega intrinsicamente um caráter universal.” (MOREIRA, 2013, p. 5)

\begin{tabular}{|l|c|cc|}
\hline Minutagem & Fala do personagem & Tradução/Legenda & \\
\hline $12: 43$ & [Em pôster] Haky & Here & \\
& kudybebonuntemdono & Drunk Ass don't have \\
& & owner & \\
& & & \\
\hline
\end{tabular}

A legenda aqui se refere ao cartaz num bar; o recurso de unir as letras tornaria a leitura extremamente difícil. O espectador/leitor possivelmente já terá dificuldade de compreensão da forma em que está, pois houve um tipo de transcrição na intenção de preservar todo o conteúdo do que estava escrito, na mesma forma, mantendo as irregularidades e peculiaridades. O erro gramatical tenta reproduzir a forma, mas o resultado não parece diminuir o esforço de processamento do receptor.

\begin{tabular}{|l|l|l|}
\hline Minutagem & Fala do personagem & \multicolumn{1}{|c|}{ Tradução/Legenda } \\
\hline $25: 30$ & Graciosa [esposa]: Nós & Graciosa [wife]: We have \\
& $\begin{array}{l}\text { já moramos em tudo quanto foi } \\
\text { canto desse mundor Já } \\
\text { moramos dentro da Vanusa, da } \\
\end{array}$ & \multicolumn{1}{l|}{ lived all over. } \\
& Vanderléia, da Cláudia Barroso. lived inside of Dolly \\
& & Turner \\
\hline
\end{tabular}

A técnica utilizada nesse trecho foi de aproximação, uma estratégia de estrangeirização, que adaptou os nomes dos carros da família, de cantoras brasileiras para cantoras/atrizes norte-americanas. Haverá um esforço mínimo de processamento por parte do receptor, e o efeito humorístico relevante é mantido. 


\begin{tabular}{|l|l|l|}
\hline Minutagem & \multicolumn{1}{|c|}{ Fala do personagem } & \multicolumn{1}{|c|}{ Tradução/Legenda } \\
\hline $31: 00$ & $\begin{array}{l}\text { Cabo Amâncio: Até que } \\
\text { enfim aparece alguma coisa que } \\
\text { preste nessa antesala do cu do } \\
\text { mundo. }\end{array}$ & $\begin{array}{l}\text { Corporal Amâncio: At last } \\
\text { some good entertainment/here in } \\
\text { the middle of nowhere. }\end{array}$ \\
\hline
\end{tabular}

Nesse trecho houve uma minimização do conteúdo, uma modulação que deliberadamente excluiu o palavrão (cu do mundo) e deixou o texto escrito mais impreciso. Não haveria espaço para uma explicação ou adaptação, mas a intenção da fala poderia ser alcançada com, por exemplo, a adição de fucking antes de nowhere; caberia na legenda e o receptor saberia que a linguagem dessa fala é mais maliciosa que o que está manifesto na legenda.

\begin{tabular}{|l|c|c|}
\hline Minutagem & Fala do personagem & Tradução/Legenda \\
\hline $40: 35$ & Médica: A loura do & Doctor: Carrie \\
& banheiro & \\
\hline
\end{tabular}

A tradução/adaptação de 'a loura do banheiro'143 por 'Carrie'144 é um exemplo da criatividade e percepção do tradutor/legendador; ambas as referências são amedrontadoras, mas também evocam a descrença e assuntos tabu, como morte, doenças, comportamentos doentios, etc.

\footnotetext{
${ }^{143}$ Personagem de lenda urbana brasileira; menina loura que morreu enquanto matava aula e agora assombra banheiros de escolas. Há várias maneiras de evocá-la.

${ }^{144}$ Personagem fictício do livro de Stephen King, Carrie é uma adolescente com poderes de telecinese que mata todos que fazem algum mal para ela.
} 


\begin{tabular}{|c|c|c|}
\hline Minutagem & Fala do personagem & Tradução/Legenda \\
\hline $44: 21$ & $\begin{array}{l}\text { Francin: Sim, pai. Mas o } \\
\text { que que tem a ver o cinema com } \\
\text { a Bliblia? } \\
\text { Francisgleydisson: Ora, } \\
\text { já pensou se Jesus não abria o } \\
\text { precedente da ressurreição? } \\
\text { Será que tinha coragem de ter } \\
\text { uma ideia dessa? } \\
\text { Francin: Égua, pai, por } \\
\text { isso que eu sou teu ídolo, ó. }\end{array}$ & $\begin{array}{l}\text { Francin: But what's the } \\
\text { correlation between/the cinema } \\
\text { and the Bible. } \\
\text { Francisgleydisson: What if } \\
\text { Jesus hadn't/invented the } \\
\text { ressurrection? } \\
\text { Could I have thought of it? } \\
\text { Francin: That's why I'm } \\
\text { your idol. }\end{array}$ \\
\hline
\end{tabular}

O humor nesse trecho aparece com a resposta do filho, que troca a correspondência e diz que ele é o ídolo do pai, e não o contrário. Aqui houve a omissão de palavras sem conteúdo verbal, pois, em relação à legenda, segundo Moreira (2013, p. 3), "que quanto mais sucinta, esta costuma ser mais fácil de assimilar”. A segunda legenda foi dividida de forma errônea, separando uma construção verbal; isso provoca cansaço de leitura e torna a legenda menos eficaz.

\begin{tabular}{|c|c|c|}
\hline Minutagem & Fala do personagem & Tradução/Legenda \\
\hline $45: 05$ & $\begin{array}{l}\text { Francisgleydisson: } \text { Tá } \\
\text { vendo aí, Francin, o mais } \\
\text { importante da tradução é tu } \\
\text { saber ler as figuras. O olho é o } \\
\text { maior troglodita. Fala qualquer } \\
\text { idioma. } \\
\text { Francin: E precisa da } \\
\text { macaúba para ler as figuras? } \\
\text { Graciosa: Não, filho, }\end{array}$ & $\begin{array}{l}\text { Francisgleydisson: You see, } \\
\text { the most important/thing in } \\
\text { translation } \\
\text { is knowing how to/read the } \\
\text { figures. } \\
\text { The eye is the best } \\
\text { troglodyte. } \\
\text { Speaks any language. } \\
\text { Francin: Do you need }\end{array}$ \\
\hline
\end{tabular}




\begin{tabular}{|l|l|l|}
\hline $\begin{array}{l}\text { macaúba é só para dublar, } \\
\text { lembra? }\end{array}$ & $\begin{array}{l}\text { macauba/to read the figures? } \\
\text { Graciosa: No, macauba } \\
\text { is/only for dubbing. }\end{array}$ \\
\hline
\end{tabular}

O trecho acima utiliza a técnica da tradução literal e consegue despertar o riso pois imagem e som complementam a legenda e o engraçado é que, na verdade, não há nada muito engraçado. Segundo Moreira (2009, p. 6), “quanto mais óbvio, mais engraçado, quanto mais simples, mais cômico; seguindo essas premissas, concluímos que a piada mais elaborada não é, necessariamente, a mais engraçada."

\begin{tabular}{|c|c|c|}
\hline Minutagem & Fala do personagem & Tradução/Legenda \\
\hline $48: 20$ & $\begin{array}{l}\text { Acrísio: Tu acha que um } \\
\text { bicho desse peitava Lampião, } \\
\text { Anfrísio? } \\
\text { Anfrísio: } \\
\text { Acrísio. } \\
\text { Acrísio: Depende, } \\
\text { quê, Anfrísio? } \\
\text { Anfrísio: Oxi, depende } \\
\text { de um monte de coisa, Acrísio. } \\
\text { Acrísio: Lampião não } \\
\text { sabia dar uma voadora dessa, } \\
\text { Anfrísio. } \\
\text { Anfrísio: } \\
\text { compensação, Lampião sabia } \\
\text { brigar de faca. }\end{array}$ & $\begin{array}{l}\text { Acrísio: You think this } \\
\text { Chinese would face Jesse James? } \\
\text { Anfrísio: Depends, Acrisio. } \\
\text { Acrísio: Depends of what, } \\
\text { Anfrisio? } \\
\text { Anfrísio: Depends on a lot } \\
\text { of things. } \\
\text { Acrísio: Jesse James didn't } \\
\text { know/how to kick like this. } \\
\text { Anfrísio: But he knew how } \\
\text { to use a gun. }\end{array}$ \\
\hline
\end{tabular}

Mais uma vez, houve uma adaptação e a mudança da referência regional/nacional Lampião para a referência Jesse James. A modulação da referência 
foi completa, pois no final, brigar de faca foi traduzido por 'use a gun', já que Jesse James era um fora-da-lei que sabia muito bem utilizar uma arma. A referência humorística permanece íntegra na legenda.

\begin{tabular}{|c|c|c|}
\hline Minutagem & Fala do personagem & Tradução/Legenda \\
\hline $49: 22$ & $\begin{array}{l}\text { Menino: Ah, cego Isaías, } \\
\text { só vai vendo. Égua, mas, ô } \\
\text { coisa medonha! Ó aí, cego, sete } \\
\text { contra um. } \\
\text { Cego: Sete? Aí é } \\
\text { setenta. }\end{array}$ & $\begin{array}{l}\text { Boy: You gotta see for } \\
\text { yourself,/Blind Isaias. } \\
\text { Awesome!/That's wild! } \\
\text { Five against one. } \\
\text { Blind man: Five? She's } \\
\text { horny. }\end{array}$ \\
\hline
\end{tabular}

Nesse trecho o humor já está implícito quando o menino diz ao cego que ele precisa ver aquilo; não há nenhuma referência discriminatória na cena, mas obviamente foi uma piada usando um estereótipo. A fala do cego parece fazer referência a uma passagem bíblica. ${ }^{145}$ Já a tradução da legenda tem claramente uma alusão sexual, não só na palavra horny como na insinuação dos five against one (cinco contra um). ${ }^{146}$

\begin{tabular}{|c|c|c|}
\hline Minutagem & Fala do personagem & Tradução/Legenda \\
\hline $57: 24$ & $\begin{array}{c}\text { Títulos dos filmes } \\
\text { [criados por Francisgleydisson] } \\
\text { A FAMÍLIA METE PÊA } \\
\text { A GALEGA } \\
\text { APAIXONADA } \\
\text { O CALANGO DO CÃO }\end{array}$ & $\begin{array}{l}\text { THE KICKASS FAMILY } \\
\text { BLONDE IN LOVE } \\
\text { DEVIL'S LIZARD } \\
\text { PLEURA DESTROYER }\end{array}$ \\
\hline
\end{tabular}

\footnotetext{
${ }^{145}$ Mateus, 18: perdoarás teu irmão não sete vezes, mas setenta vezes sete.

${ }^{146} \mathrm{Cinco}=$ dedos $/$ um $=$ pênis .
} 


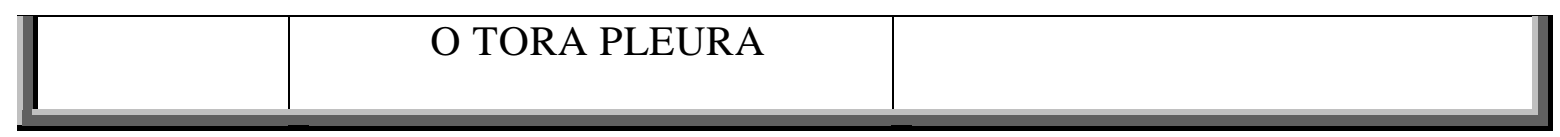

Não são as falas traduzidas aqui, mas sim os títulos dos filmes que seriam apresentados no cinema. A estratégia de tradução foi a adaptação e o humor foi mantido, pois os títulos causam estranheza nas duas línguas.

\begin{tabular}{|l|c|c|}
\hline Minutagem & Fala do personagem & Tradução/Legenda \\
\hline $58: 50$ & Bêbado: Olhe aqui, tira & Drunkard: Here, it's all on \\
& $\begin{array}{l}\text { aí uma inteira, duas meia, e o } \\
\text { troco o senhor compre de } \\
\text { farinha para dar de comer a } \\
\text { esses chinesinhos aí que tão } \\
\text { tudo encardido de fome. }\end{array}$ & and you can keep the cange. \\
\hline
\end{tabular}

A legenda nesse trecho omitiu diversos elementos da fala e ainda tinha um erro importante de ortografia $($ cange $=$ change). Houve uma dizimação, com perda tanto de conteúdo semântico quanto de conteúdo estilístico. Quase chegou à resignação, apontada por Gottlieb (2004) como resultado da incapacidade de traduzir a mensagem. Gerou um conflito, pois muita coisa foi dita e pouco foi legendado.

\begin{tabular}{|c|c|c|}
\hline Minutagem & Fala do personagem & Tradução/Legenda \\
\hline $1: 14: 58$ & $\begin{array}{l}\text { Homem: Ei, Isaías, cego } \\
\text { pode pagar à vista? } \\
\text { Isaías: Aidético, baitola. }\end{array}$ & $\begin{array}{l}\text { Man: } \text { Hey } \\
\text { Isaias,/what scene did you like } \\
\text { most? } \\
\text { Blind Isaias: Your mother } \\
\text { fucking. }\end{array}$ \\
\hline
\end{tabular}

Mais uma vez, a alusão à cegueira de Isaías brinca com estereótipos e linguagem obscena. $\mathrm{Na}$ fala original, a piada é com cegueira x pagar a vista, e a 
resposta foi um xingamento mais suave. Na legenda, a menção à cegueira foi mais moderada; talvez por isso a resposta tenha sido mais intensa, usando a estratégia da modulação e neologismo. Na verdade, foram duas piadas distintas; "o tradutor tem que ser, em certa medida, um inventor e um desafiador" ${ }^{\prime 47}$ (PANEK, 2009, p. 51).

\begin{tabular}{|c|c|c|}
\hline Minutagem & Fala do personagem & Tradução/Legenda \\
\hline $1: 20: 15$ & $\begin{array}{l}\text { Moça: Tá vendo que eu } \\
\text { vou acreditar num leruaite } \\
\text { desse. } \\
\text { Homem: Leruaite? Você } \\
\text { fala inglês, é? Fala inglês? }\end{array}$ & $\begin{array}{l}\text { Lady: Do you think I } \\
\text { actually/believe in this baloney? } \\
\text { Man: Bologne? Does she } \\
\text { speak English?/She speaks } \\
\text { English? }\end{array}$ \\
\hline
\end{tabular}

Aqui a piada é linguística e também cultural. O tradutor conseguiu criar um mecanismo de substituição para o jogo de palavras que foi extremamente eficaz e se encaixou perfeitamente na legenda. A piada na língua original é de compreensão mais difícil. ${ }^{148}$

\begin{tabular}{|l|c|c|}
\hline Minutagem & Fala do personagem & \multicolumn{1}{|c|}{ Tradução/Legenda } \\
\hline $1: 23: 18$ & Homem: Ai, essa prega & Man: He tore his asshole \\
& rainha! & wrinkles! \\
\hline
\end{tabular}

Essa fala curta exemplifica a estratégia da transferência com explicação, segundo Barbosa (2007, p. 74): “a condição necessária para o emprego da transferência [...] é que o leitor possa apreender seu significado através do contexto". A explicação, contida na legenda, é o verbo tore (tear = rasgar) que, associada à imagem, faz com que o espectador/leitor compreenda o que foi dito.

\footnotetext{
147 "a translator must be an inventor and a challenger to some extent."

${ }^{148}$ Leruaite $=$ conversa mole; xavecagem; conversa para boi dormir.
} 


\begin{tabular}{|l|l|l|}
\hline Minutagem & Fala do personagem & Tradução/Legenda \\
\hline $1: 24: 30$ & [pôster] & Don't miss!! \\
& Não perda! & The hero against the villain \\
& O artista contra o caba & \\
\hline
\end{tabular}

Aqui não há nenhuma forma de transcrição - de modo a manter o erro, a irregularidade - e há uma modulação para, de certa forma, simplificar o texto. Não há conflito ou ganho; talvez, como afirma Ridd (apud MOREIRA, 2013, p. 3), “inevitavelmente, algo da fala estará ausente nas legendas e o tradutor estará omitindo informação disponível para o espectador do filme”.

A partir de 1:26:45, há uma entrevista com Francisgleydisson - em inglês com legendas em português. As estratégias se invertem, mas ainda assim refletem a leitura e a interpretação do tradutor, pois, como afirma Bassnett (apud MOREIRA, 2009, p. 4), “a legenda é o resultado da interpretação do sentido geral do texto, que não pode ser dissociado da imagem”. 
3.6. O Bem Amado - The Well Loved One

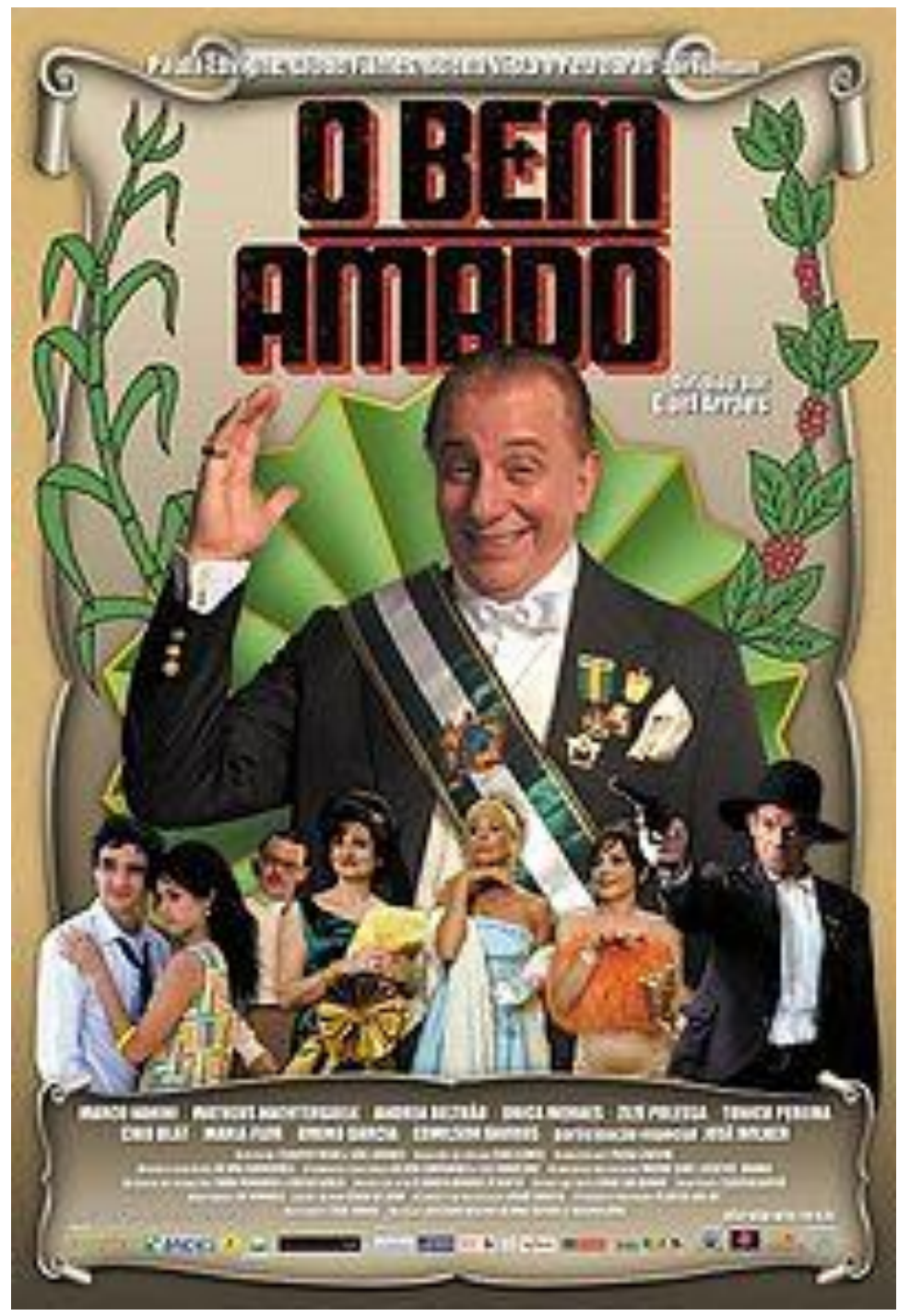

Figura 10. Capa do DVD do filme $O$ bem amado.

O filme “O Bem Amado" é um filme brasileiro de 2010, do gênero comédia dramática, dirigido por Guel Arraes, cuja estória se passa na cidade fictícia de Sucupira. Baseado na obra homônima de Dias Gomes, O Bem Amado conta a história do prefeito Odorico Paraguaçu, que tem como meta prioritária em sua administração na cidade de Sucupira a inauguração de um cemitério. De um lado é apoiado pelas irmãs Cajazeiras. Do outro, tem que lutar contra a forte oposição liderada por Vladmir, dono do jornaleco da cidade. Por falta de defunto, o prefeito nunca consegue realizar sua meta. Nem mesmo a chegada de Ernesto - um moribundo que não morre - e a contratação de Zeca Diabo, um cangaceiro matador, lhe proporcionam a realização do sonho. Odorico arma situações para que alguém 
morra, mas o primeiro corpo a ser sepultado em Sucupira será o do próprio prefeito, que de caçador se torna caça e passa de vilão à mártir. [wikipedia]

A história, segundo o DVD:

Baseado na obra de Dias Gomes, O BEM AMADO conta a história do prefeito Odorico Paraguaçu, que tem como meta prioritária em sua administração na cidade de Sucupira, a inauguração de um cemitério. De um lado é apoiado pelas irmãs Cajazeiras. Do outro, tem que lutar contra a forte oposição liderada por Vladimir, dono do jornaleco da cidade. Por falta de defunto, o prefeito tem dificuldade para realizar sua meta, mesmo depois da chegada de Ernesto - um moribundo que não morre - e a contratação de Zeca Diabo, um cangaceiro matador.

As legendas são brancas com bordas pretas e centralizadas na parte inferior da tela. O título foi traduzido por "The Well Beloved One”, tradução literal.

\begin{tabular}{|c|c|c|}
\hline Minutagem & Fala do personagem & Tradução/Legenda \\
\hline $1: 10$ & 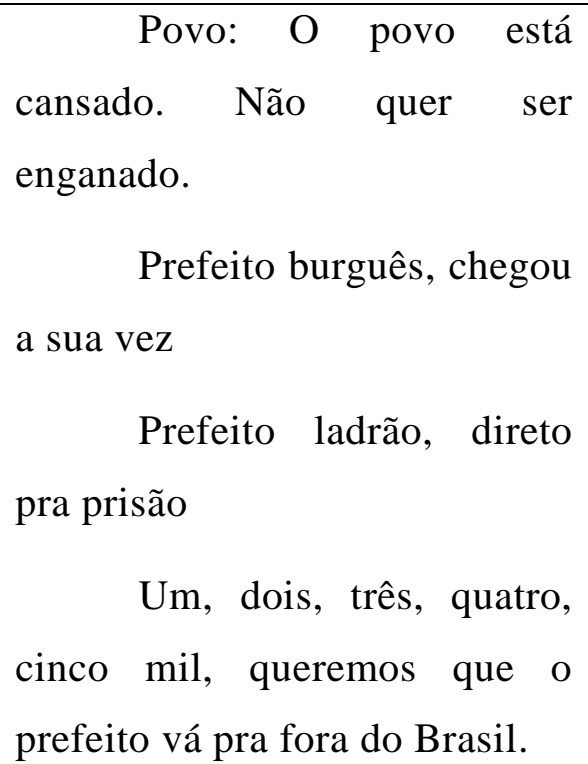 & $\begin{array}{l}\text { People: People are } \\
\text { tired./Don't want to be deceived } \\
\text { any longer. } \\
\text { Bourgeois mayor your time } \\
\text { has come/mayor thief straight to } \\
\text { jail... } \\
\text { One two three four } \\
\text { We don't want this } \\
\text { mayor/in brazil any more. }\end{array}$ \\
\hline
\end{tabular}

No início do filme, o povo está gritando palavras de ordem, com rimas; a primeira parte não teve rima na legenda, mas na segunda foi feita uma adaptação e a rima 'mil/Brasil' foi traduzida para 'four/more'. A primeira frase foi traduzida literalmente; houve tradução literal na segunda frase e um acréscimo na terceira, que 
deixou a estrutura meio truncada. O toque de humor - com uma pitada de ironia está na cena, do povo arremetendo contra os policiais e o personagem Zeca Diabo passando tranquilamente por todos eles, entrando na prefeitura e matando o prefeito.

\begin{tabular}{|c|c|c|}
\hline Minutagem & Fala do personagem & Tradução/Legenda \\
\hline $5: 24$ & $\begin{array}{l}\text { Odorico: Estou aqui, } \\
\text { com a alma lavada e enxaguada } \\
\text { de indignação, por esse } \\
\text { atentado covardista } \\
\text { crapulento. }\end{array}$ & $\begin{array}{l}\text { Odorico: Here I am... } \\
\text { with my soul washed/and } \\
\text { rinsed with indignation... } \\
\text { for this cowardly } \\
\text { and/heinous assassination. }\end{array}$ \\
\hline
\end{tabular}

A primeira fala do candidato a prefeito já mostra que o discurso é pontilhado de frases feitas, de palavras criadas, que certamente criam situações humorísticas. A tradução utiliza muitas adaptações, compensações e transposições. Também a tradução literal, como no trecho acima; em alguns momentos, o toque humorístico que na fala é predominantemente linguístico - acaba não sendo transferida completamente para a legenda. O excesso de palavras formais e 'inesperadas' é percebido como o toque de humor ou de ironia das legendas.

\begin{tabular}{|c|c|c|}
\hline Minutagem & Fala do personagem & Tradução/Legenda \\
\hline $6: 15$ & $\begin{array}{l}\text { Candidato: Uma galinha, } \\
\text { mesmo caipira, está custando } \\
\text { mil cruzeiros. Eu pergunto, } \\
\text { quem é que pode comer uma } \\
\text { galinha de mil cruzeiros? } \\
\text { Moleza: O galo, doutor! }\end{array}$ & $\begin{array}{l}\text { Candidate: A chicken costs } \\
\text { a thousand cruzeiros. } \\
\text { Who can eat... } \\
\text { a thousand-cruzeiros } \\
\text { chicken? } \\
\text { Moleza: The rooster Sir }\end{array}$ \\
\hline
\end{tabular}

A piada aqui é fácil e todo o composto multimodal - imagem e som - do filme colabora para a criação do momento humorístico. A tradução literal funcionou porque a piada é universal, assim como a alusão sexual do verbo 'comer'/'eat. 


\begin{tabular}{|c|c|c|}
\hline Minutagem & Fala do personagem & Tradução/Legenda \\
\hline $7: 10$ & $\begin{array}{l}\text { Repórter [em off]: O } \\
\text { planeta vivia na iminência de } \\
\text { uma guerra nuclear que } \\
\text { destruiria a humanidade. Mas } \\
\text { nada comparável à batalha } \\
\text { travada entre as forças políticas } \\
\text { de Sucupira. }\end{array}$ & $\begin{array}{l}\text { Reporter [off]: The planet } \\
\text { was on the verge of a nuclear/war } \\
\text { that would destroy the human race. } \\
\text { But nothing compared to the } \\
\text { battle/between the political forces } \\
\text { of Sucupira. }\end{array}$ \\
\hline
\end{tabular}

Nesse trecho, o toque de humor está no exagero; de novo, a estratégia usada é a tradução literal e o único senão das legendas é a divisão de 'nuclear/war'; talvez a solução seria uma terceira legenda para a divisão ser mais natural. Aqui também há uma música - Esta Terra, de Caetano Veloso ${ }^{149}$ - que bem poderia ser considerada um personagem do filme. Como afirma Díaz-Cintas (DÍAZ-CINTAS e REMAEL, 2007, p. 210), “idealmente, a música deveria ser traduzida na legendagem de um filme estrangeiro" $" 150$, a menos que o espaço não seja suficiente.

\begin{tabular}{|c|c|c|}
\hline Minutagem & Fala do personagem & Tradução/Legenda \\
\hline $8: 58$ & $\begin{array}{l}\text { Odorico: Um vexame } \\
\text { pro nosso prefeito, agora em } \\
\text { estado } \text { de } \quad \text { defuntice } \\
\text { compulsória, ter que andar três } \\
\text { léguas para ser enterrado. }\end{array}$ & $\begin{array}{l}\text { Odorico: Shame for our } \\
\text { mayor, now in state/of compulsory } \\
\text { deceasedness... } \\
\text { having to walk three } \\
\text { leagues/to be buried. }\end{array}$ \\
\hline
\end{tabular}

Toda a fala do personagem é humorística, pautada pelo exagero. A técnica da tradução literal foi utilizada novamente, e o efeito humorístico permanece, não só pelo vocabulário mas também porque o prefeito morto 'teve que andar três léguas para ser enterrado'.

\footnotetext{
${ }^{149}$ https://www.youtube.com/watch?v=_rfZHhAhSxQ

150 "Ideally, the song ought to be translated when subtitling the film into a foreign language."
} 


\begin{tabular}{|c|c|c|}
\hline Minutagem & Fala do personagem & Tradução/Legenda \\
\hline $10: 15$ & $\begin{array}{l}\text { Odorico: Povo de } \\
\text { Sucupira, meus conterrâneos. } \\
\text { Venho de branco para ser mais } \\
\text { claro. }\end{array}$ & $\begin{array}{l}\text { Odorico: People from } \\
\text { Sucupira,/my fellow citizens. I } \\
\text { came dressed in white/to make } \\
\text { myself more clear. }\end{array}$ \\
\hline
\end{tabular}

O curto trecho acima tem um toque de humor óbvio que, como já mencionado, quanto mais óbvio, mais engraçado. Aqui há mais uma música sem tradução, e pode-se dizer que houve certa perda de conteúdo, pois é uma música composta para o filme e há a possibilidade de inserir a legenda. Mas, como alega Moreira (2013, p. 8), “o legendista é quem escolhe colocar ou não uma marca em cada discurso, é quem decide, prioriza, omite, acrescenta, cria. Cada escolha tradutória tem uma razão de ser."

\begin{tabular}{|l|r|l|}
\hline Minutagem & Fala do personagem & \multicolumn{1}{|c|}{ Tradução/Legenda } \\
\hline $11: 28$ & Odorico: E o coração nu, & \multicolumn{1}{|c|}{ Odorico: e naked heart, } \\
& $\begin{array}{l}\text { despido estriptisicamente de } \\
\text { qualquer ambição de glória. }\end{array}$ & $\begin{array}{l}\text { stripped nude/of any ambition for } \\
\text { glory. }\end{array}$ \\
\hline
\end{tabular}

Nesse trecho curto o humor é mais uma vez óbvio, e a tradução, literal, exceto pela palavra criada (estriptisicamente) pelo personagem. Há um erro na legenda: a não tradução de 'e' por 'and'. Não representa um problema para a compreensão, é apenas uma falha técnica.

\begin{tabular}{|l|c|c|}
\hline Minutagem & \multicolumn{1}{|c|}{ Fala do personagem } & \multicolumn{1}{c|}{ Tradução/Legenda } \\
\hline $12: 31$ & \multicolumn{1}{|c|}{ Repórter [em off]: Esta } & \multicolumn{1}{c|}{ Reporter [off]: this story is } \\
& $\begin{array}{l}\text { estória é a reconstituição fiel } \\
\text { destes fatos. Ou não. }\end{array}$ & $\begin{array}{l}\text { a precise, or not,/recollection of } \\
\text { these events. }\end{array}$ \\
\hline
\end{tabular}


Aqui, o marcador de ironia ('ou não') foi transferido para o meio da frase, perdendo um pouco sua carga semântica; o local onde a locução foi inserido pode até ser considerado 'agramatical', pois separa o adjetivo do substantivo que ele modifica.

\begin{tabular}{|c|c|c|}
\hline Minutagem & Fala do personagem & Tradução/Legenda \\
\hline $14: 14$ & 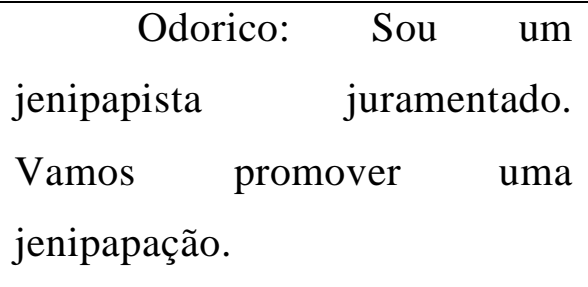 & $\begin{array}{l}\text { Odorico: I am a certified } \\
\text { Jenipapist. } \\
\text { Let's } \\
\text { Jenipapation. }\end{array}$ \\
\hline
\end{tabular}

A estratégia utilizada nesse trecho foi o decalque e a aclimatação, com a adição dos sufixos '-ist' e '-ation'; ocorreu uma exotização que funciona como gatilho de humor. O estranho/bizarro provoca o riso. Segundo Barbosa (2007, p. 73), "através desse processo [aclimatação], um radical estrangeiro se adapta à fonologia e à estrutura morfológica da língua que o importa.”

\begin{tabular}{|c|c|c|}
\hline Minutagem & Fala do personagem & Tradução/Legenda \\
\hline $16: 14$ & $\begin{array}{l}\text { Dulcineia: O senhor não } \\
\text { quer sentar, tomar um licor? } \\
\text { Odorico: Ótimo, ótimo. } \\
\text { Faremos uma sofação } \\
\text { licorística. Ou, se preferir, uma } \\
\text { licoração sofadística. }\end{array}$ & $\begin{array}{l}\text { Dulcineia: Would you like } \\
\text { to sit down,/drink a liqueur? } \\
\text { Odorico: Great idea. We'll } \\
\text { have a liquery couching. } \\
\text { Or if you prefer a } \\
\text { couchy/liquoration }\end{array}$ \\
\hline
\end{tabular}

O diálogo é uma sequência do diálogo anterior e os procedimentos utilizados são semelhantes, sendo a brincadeira aqui 'gramatical'. Em quase todas as legendas aqui transcritas, o procedimento mais utilizado foi a tradução literal, e ela funciona porque é direta e vem acompanhada de todo os gestos, movimentos e expressões faciais dos personagens. Segundo Moreira (2013, p. 4/5), 
Quando a legenda é resultado da tradução de humor é ainda de maior importância considerar a imagem e o gestual das cenas, informações fundamentais são apreendidas através de um olhar, do posicionamento corporal dos atores. Em alguns momentos os personagens se comunicam através de mímicas ou fazem caretas, em outro momento, o efeito humorístico fica a cargo da caracterização do personagem que, por si só já é engraçada.

\begin{tabular}{|c|c|c|}
\hline Minutagem & Fala do personagem & Tradução/Legenda \\
\hline $17: 57$ & $\begin{array}{l}\text { Odorico: Eu entendo. } \\
\text { Emboramente meu peito vá } \\
\text { continuar sempre em festa com } \\
\text { as lembranças desta noite e suas } \\
\text { promessas de etceteras. }\end{array}$ & $\begin{array}{l}\text { Odorico: I understand... } \\
\text { Though, my heart will } \\
\text { continue/to rejoice with the } \\
\text { memories... } \\
\text { of this evening/and your } \\
\text { promises of etc... }\end{array}$ \\
\hline
\end{tabular}

As 'promessas de etceteras' são uma sutil alusão sexual, tanto na fala original quanto na tradução. Aqui, a referência não é explícita, mas velada; no entanto, as imagens e o gestual dos personagens tornam a cena divertida, e a insinuação, leve. $\mathrm{O}$ eufemismo aqui utilizado mostra que, como afirma Santaemilia (2010, p. 140),

A tradução do sexual nos situa diante de nossas contradições mais íntimas, diante daquilo que podemos dizer e daquilo que temos que calar, diante de onde situamos os limites do aceitável moral, linguística ou sexualmente. ${ }^{151}$

\begin{tabular}{|l|l|llr|}
\hline Minutagem & \multicolumn{2}{|c|}{ Fala do personagem } & \multicolumn{3}{c|}{ Tradução/Legenda } \\
\hline $19: 14$ & $\begin{array}{l}\text { Odorico: Estamos na } \\
\text { hora do expediente, o senhor é } \\
\text { funcionário da prefeitura, e este } \\
\text { serviço é incompatível com seus } \\
\text { borboleteamentos. }\end{array}$ & $\begin{array}{l}\text { Odorico: } \\
\text { business hours,/you are a town hall } \\
\text { employee... }\end{array}$ & and & on \\
& this & work & is \\
\hline
\end{tabular}

151 “La traducción de lo sexual nos sitúa ante nuestras contradicciones más íntimas, ante aquello que podemos decir y aquello que hemos de callar, ante dónde situamos los límites de lo moral, lingüística o sexualmente aceptable." 


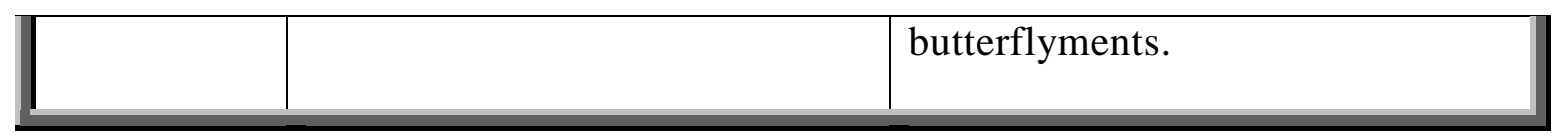

A tradução literal, mais uma vez utilizada aqui, é aquela "em que se mantém uma fidelidade semântica estrita, adequando porém a morfo-sintaxe às normas gramaticais da língua da tradução" (BARBOSA, 2007, p. 65). Tanto os borboleteamentos quanto os 'butterflyments' são palavras criadas para esse contexto. Segundo Gottlieb (2005, p. 16), quando a pessoas compram filmes estrangeiros, "elas esperam e aceitam a cultura estrangeira ostensiva". 152

\begin{tabular}{|c|c|c|}
\hline Minutagem & Fala do personagem & Tradução/Legenda \\
\hline $21: 12$ & $\begin{array}{l}\text { Dono do jornal: E o } \\
\text { povo sabe o que é certo ou } \\
\text { errado, rapaz? Se soubesse, não } \\
\text { teria eleito esse canalha! } \\
\text { Repórter: Não sei se está } \\
\text { certo ou errado, mas que está } \\
\text { dando certo, isso tá. Odorico } \\
\text { nunca teve tão popular. Você } \\
\text { não tem saída, homem. Aderir } \\
\text { você não pode, e protestar não } \\
\text { vai dar em nada. } \\
\text { lidar com canalhas, somente } \\
\text { agindo como um canalha. }\end{array}$ & $\begin{array}{l}\text { Newspaper owner: The } \\
\text { population doesn't know/right } \\
\text { from wrong. } \\
\text { If it did it would not } \\
\text { have/elected the bastard! } \\
\text { Reporter: I don't know if } \\
\text { it's right/or wrong but it's working } \\
\text { alright! } \\
\text { He has never been so } \\
\text { popular. } \\
\text { You have no choice } \\
\text { You can't join him, and } \\
\text { protesting/won't get us anywhere. } \\
\text { Owner: You're right. } \\
\text { In order to deal with } \\
\text { bastards/you have to act like a one. }\end{array}$ \\
\hline
\end{tabular}

152 "...they expect and accept the foreign culture to show." 
O diálogo é cheio de insinuações irônicas, pois o dono do jornal em questão é o opositor do prefeito. Como não há divergência do sistema linguístico, de estilo ou de realidade extralinguistica - principalmente por se tratar de uma obra de realismo fantástico - a tradução literal e a tradução palavra-por-palavra são os procedimentos que foram descritos por Heloisa Barbosa para essa tradução. Nesse modelo, segundo Newmark (apud PANEK, 2009, p. 50), “o referente e o efeito pragmático são equivalentes, i.e., as palavras não só se referem à mesma coisa, mas têm associações similares" $" 153$. Mais uma vez há uma música (sobre a bandeira do partido revolucionário) que poderia ter sido traduzida/legendada; o espectador/leitor se beneficiaria de mais esse recurso da tradução audiovisual. ${ }^{154}$

\begin{tabular}{|c|c|c|}
\hline Minutagem & Fala do personagem & Tradução/Legenda \\
\hline $22: 18$ & $\begin{array}{l}\text { Odorico: Não deem } \\
\text { ouvidos à essa imprensa } \\
\text { subvertente e marronzista. }\end{array}$ & $\begin{array}{l}\text { Odorico: Do not listen to } \\
\text { this disgusting,/subversive and } \\
\text { yellowish press. }\end{array}$ \\
\hline
\end{tabular}

A estratégia utilizada aqui foi a equivalência direta com o recurso da sufixação para se adequar à fala e dar um toque de humor. Também houve o acréscimo de um vocábulo, possivelmente escolha do tradutor, pois "o legendista é quem escolhe colocar ou não uma marca em cada discurso, é quem decide, prioriza, omite, acrescenta, cria" (MOREIRA, 2013, p. 8).

\begin{tabular}{|l|l|c|}
\hline Minutagem & Fala do personagem & Tradução/Legenda \\
\hline $24: 21$ & \multicolumn{1}{|c|}{ Odorico: Eu sou homem } \\
& $\begin{array}{l}\text { de uma palavra só, não sou um } \\
\text { bi-vocabular. }\end{array}$ & $\begin{array}{l}\text { Odorico: I'm a man of one } \\
\text { word,I'm not a man of two words. }\end{array}$ \\
\hline
\end{tabular}

Nesse curto trecho, houve uma explicitação que poderia ter sido substituída por um neologismo; como na fala original houve a criação de uma palavra (bi-

\footnotetext{
153 "the referent and the pragmatic effect are equivalent, i.e., the words not only refer to the same thing but have similar associations."

${ }^{154}$ A legenda aqui poderia estar em itálico, ou vir entre parênteses, como o 'closed caption', ou legenda oculta.
} 
vocabular), assim também poderia ter acontecido na tradução (bi-wordy, por exemplo).

\begin{tabular}{|c|c|c|}
\hline Minutagem & Fala do personagem & Tradução/Legenda \\
\hline $34: 37$ & $\begin{array}{l}\text { Odorico: Nem que chova } \\
\text { cabelo de sapo! Não quero você } \\
\text { de namorismo com aquele } \\
\text { elemento subversente e } \\
\text { esquerdizante da imprensa } \\
\text { marronzista. }\end{array}$ & $\begin{array}{l}\text { Odorico: Not even if starts } \\
\text { raining frog's hair! } \\
\text { I don't want you dating that } \\
\text { subversive/and leftish element... } \\
\text { from the yellowish press. }\end{array}$ \\
\hline
\end{tabular}

Todas as referências da fala original nesse trecho são de difícil tradução. $\mathrm{Na}$ primeira parte, a estratégia usada foi a tradução literal (cabelo de sapo - frog's hair). Já na segunda frase, 'namorismo', 'subversente' e 'esquerdizante' são palavras que não são comumente utilizadas, e que foram traduzidas com o uso de sufixações e substituições.

\begin{tabular}{|l|r|c|}
\hline Minutagem & Fala do personagem & Tradução/Legenda \\
\hline $58: 40$ & Odorico: É um indivíduo & Odorico: He is a double \\
& de duas caras, é um bi-facial! & face individual,/a bi-facial! \\
\hline
\end{tabular}

Aqui foi utilizada a estratégia do neologismo, como sugerido na legenda do minuto 24. O humor ficou de fácil entendimento e a legenda, literal e eficaz. Segundo Pedersen (2005, p. 5), “a carga semântica do texto fonte fica inalterada: nada é acrescentado, ou subtraído. Não há nenhum esforço para transferir conotações ou guiar o público alvo" 155 .

\begin{tabular}{|l|l|l}
\hline Minutagem & Fala do personagem & Tradução/Legenda \\
\hline
\end{tabular}

\footnotetext{
155 “... the semantic load of the ST ECR is unchanged: nothing is added, or subtracted. There is no effort made to transfer connotations or guide the TT audience in any way."
} 


\begin{tabular}{|l|rr|r|}
\hline $1: 13: 40$ & $\begin{array}{r}\text { Dulcineia: Ai, Do, } \\
\text { parece fotonovela. }\end{array}$ & $\begin{array}{r}\text { Dulcineia: Sound like a pulp } \\
\text { romance. }\end{array}$ \\
\hline
\end{tabular}

Por fim, apenas uma referência que foi traduzida por aproximação. A fotonovela é uma novela em quadrinhos que utiliza, no lugar dos desenhos, fotografias; foram muito populares entre as décadas de 1950 e 1970. Já o 'pulp romance', ou revista pulp, era o nome dado às revistas feitas com papel barato, fabricado a partir de polpa de celulose; tinham um clima noir, mas também havia histórias de fantasia e ficção científica.

No final do filme, repete-se a música do Odorico, e mais uma vez ela não é traduzida. O filme tem várias referências culturais, humorísticas e irônicas. $\mathrm{Na}$ verdade, os três aspectos estão interligados, o humor e a ironia são entendidos dentro de um esquema cultural implícito, pois

ambos serão determinados pelo tipo de texto e pelas convenções tradutórias, culturais e sociais da sua época, o tipo de receptor que têm em mente, o meio escolhido para a tradução, os valores relacionados à ironia, o que a comunidade pensa sobre ironia (MATEO, 2010, 216) 


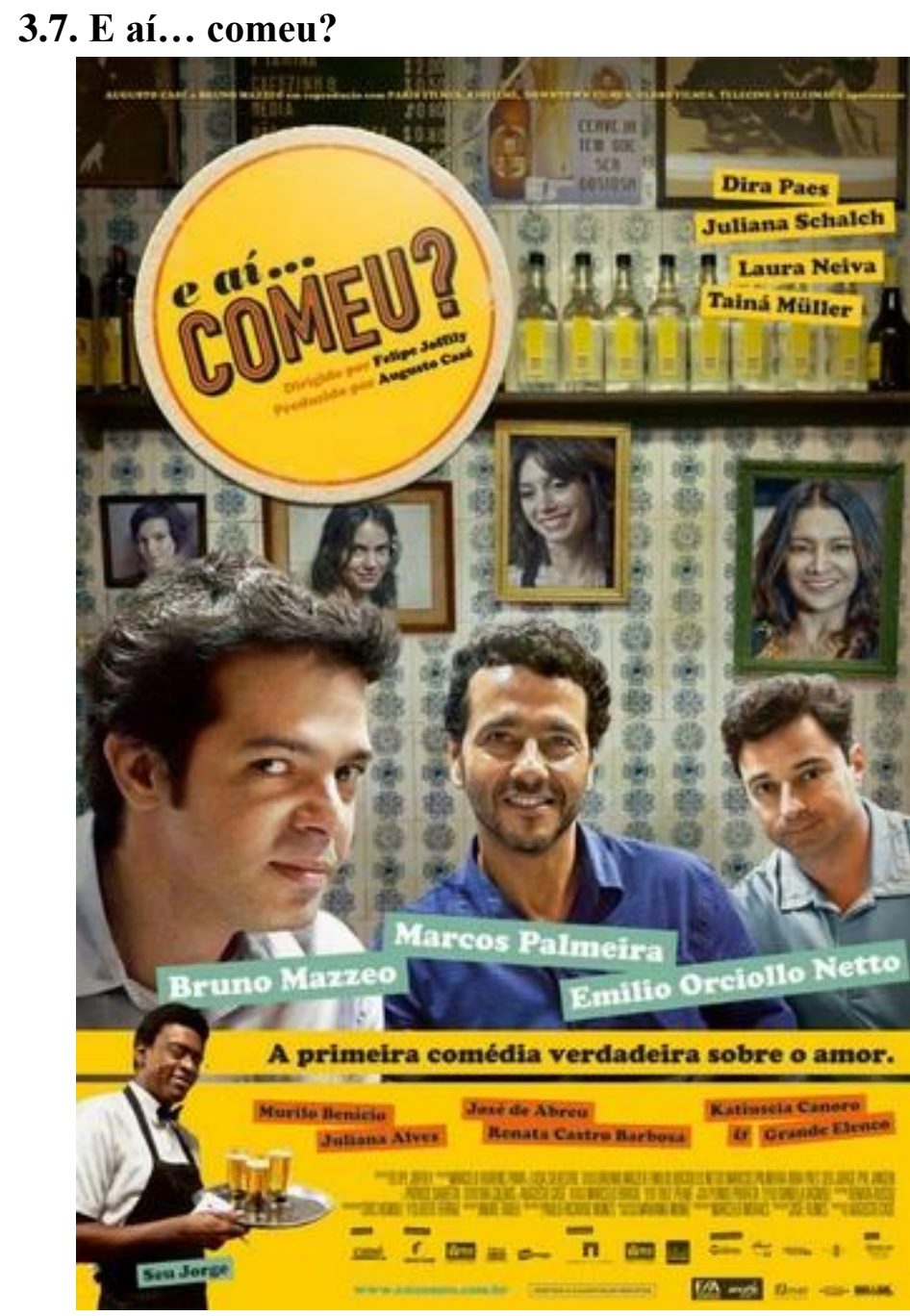

Figura 11. Capa do DVD do filme E aí... comeu?

E Aí... Comeu? é um filme de comédia brasileiro de 2012. Foi dirigido por Felipe Joffily, roteirizado por Marcelo Paiva e estrelado por Bruno Mazzeo, Marcos Palmeira e Emilio Netto. O filme é uma adaptação de uma peça homônima de Marcelo Rubens Paiva. Foi lançado em 22 de junho de 2012 pela Paris Filmes e teve uma receita de $\mathrm{R} \$ 26.157 .268$.

Fernando é um recém-separado, e não se conforma com o fracasso de seu casamento com Vitória, enquanto seu amigo Honório, um jornalista machão casado com Leila, não para de desconfiar que a esposa está traindo ele. Também amigo da dupla, Afonsinho sonha em ser um escritor de sucesso, tira onda de intelectual e se relaciona com prostitutas. Juntos, eles vão debater e descobrir qual é o papel deles nesse mundo povoado por mulheres, sejam elas interesses amorosos ou não. 
Em outubro de 2010, o filme já estava entrando em produção com Bruno Mazzeo, Emílio Orciollo e Marcos Palmeira já escalados para interpretar Fernando Moreira, Afonso Carvalho e Honório Alves, respectivamente. As filmagens se iniciaram apenas em novembro de 2011 no Rio de Janeiro e veio a ser finalizada em dezembro do mesmo ano.

\section{A história, segundo o DVD:}

Fernando (Bruno Mazzeo), Honório (Marcos Palmeira) e Fonsinho (Emilio Orciollo Netto) são três amigos de infância que justos procuram entender, no mundo atual, o papel do homem diante da nova mulher, após o fracasso do casamento de um deles.

As legendas são também brancas com bordas pretas, centralizadas no canto inferior da tela. De maneira geral, as divisões são feitas de acordo com modelos otimizados - que facilitam a leitura - e elas não interferem na imagem. O título do filme não foi traduzido.

\begin{tabular}{|c|c|c|}
\hline Minutagem & Fala do personagem & Tradução/Legenda \\
\hline $3: 00$ & $\begin{array}{l}\text { Honório: A noite tá uma } \\
\text { guerra, meu amigo. E a briga é } \\
\text { entre elas mesmas. Tudo pela } \\
\text { gente. Os espólios da guerra. O } \\
\text { botim somos nós, meu } \\
\text { camarada. Assim de mesa só de } \\
\text { mulher. Amigas até aparecer o } \\
\text { primeiro pedaço de pinto. Aí, } \\
\text { esquece as Barbies, Sex and the } \\
\text { City, esquece tudo: o bicho } \\
\text { pega. É dedo no olho, puxão de } \\
\text { cabelo, chutãozinho na coxa, } \\
\text { fofoca, vale tudo. Se a gata já }\end{array}$ & $\begin{array}{l}\text { Honório: Night is a war, my } \\
\text { friend. And the/ladies fight } \\
\text { amongst themselves. } \\
\text { Because of us. } \\
\text { Remains of war./We are the } \\
\text { booty, my friend. } \\
\text { Lots of tables full of } \\
\text { women. } \\
\text { Friends,/until the first dick } \\
\text { shows up. } \\
\text { After that, forget about } \\
\text { Barbies,/Sex and the City, forget }\end{array}$ \\
\hline
\end{tabular}




\begin{tabular}{|c|c|}
\hline $\begin{array}{l}\text { passou dos } 30 \text { e ainda não } \\
\text { casou, rapaz, ela sai pra noite } \\
\text { com tudo. A gente tem que } \\
\text { estar preparado. Corpo } \\
\text { trabalhado e dois Viagras no } \\
\text { bolso, pra garantir a cravada da } \\
\text { noite e a fincada da manhã. É a } \\
\text { revolução! Nós somos um } \\
\text { tesouro a ser conquistado. Nós } \\
\text { somos Constantinopla e elas são } \\
\text { os turcos. Quer dizer, nós não, } \\
\text { né, vocês. Que eu sou casado. } \\
\text { Fernando: } \\
\text { amarrado também pasta. } \\
\text { Honório: Não sou } \\
\text { cavalo. Apesar do tamanho do } \\
\text { meu pau, como você deve ter } \\
\text { notado. }\end{array}$ & 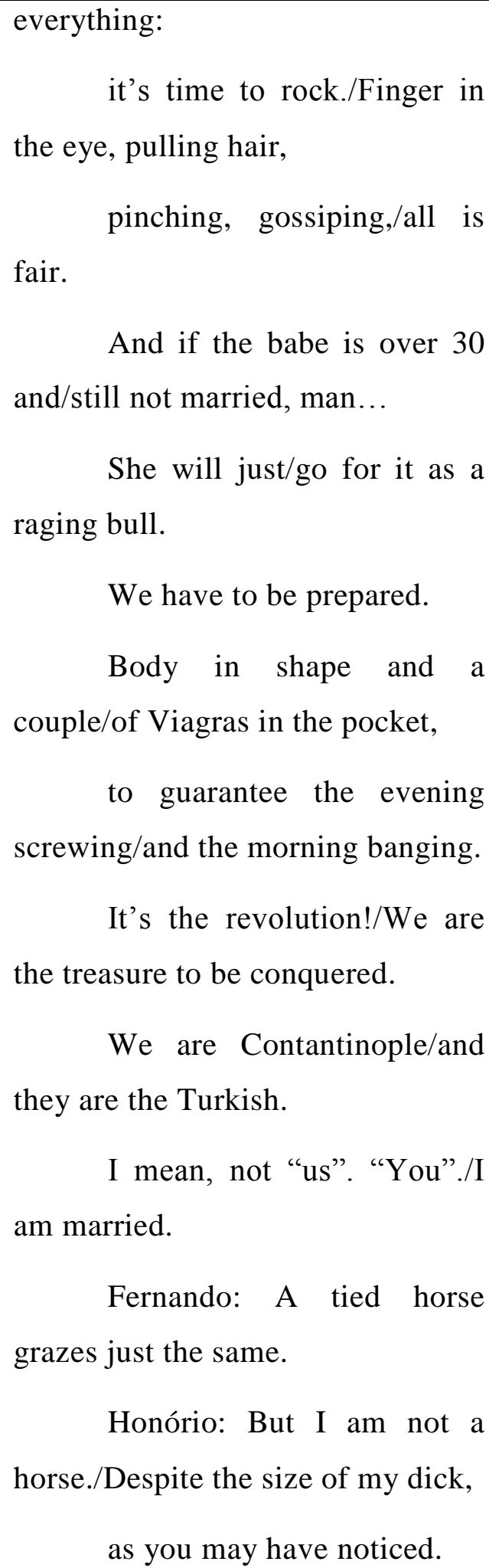 \\
\hline
\end{tabular}

A primeira fala do filme - com dois amigos conversando no banheiro de um bar, já traz o tom de humor sarcástico e de alusões sexuais, implícitas e explícitas. As estratégias usadas para a tradução foram a tradução literal, a substituição (o 
bicho pega = it's time to rock), e a transferência direta (Barbie e Sex and the City). A referência direta à Barbies e ao seriado Sex and the City acontece porque são elementos que já pertencem à cultura estrangeira. Talvez a expressão A tied horse grazes just the same, traduzida literalmente, seja um pouco estranha à cultura estrangeira, mas a ideia é transmitida e a referência humorística também. Não houve modulação da linguagem sexual, com eufemismos ou disfemismos; as referências são diretas e, nas palavras de Santaemilia (2005, p. 15), “a linguagem do sexo revela e reforça suposições culturais e ideológicas importantes (subjacentes), e é provavelmente o dispositivo contextualizador mais poderoso que existe."156

\begin{tabular}{|c|c|c|}
\hline Minutagem & Fala do personagem & Tradução/Legenda \\
\hline 7:05 & $\begin{array}{l}\text { Fernando: } \\
\text { comendo muito mal em todos } \\
\text { os sentidos. Principalmente o } \\
\text { duplo sentido. Tenho a } \\
\text { sensação de que eu não trepo } \\
\text { desde que o Zico perdeu o } \\
\text { pênalti na Copa do México. }\end{array}$ & $\begin{array}{l}\text { Fernando: I have been } \\
\text { eating poorly/in all respects, } \\
\text { especially sexually } \\
\text { speaking. } \\
\text { It feels like I haven't had } \\
\text { sex } \\
\text { since Zico missed the } \\
\text { penalty/in the Mexico World Cup. }\end{array}$ \\
\hline
\end{tabular}

A piada nesse trecho tem conotação sexual e referências culturais bem específicas, que foram traduzidas literalmente; houve também uma explicitação da alusão sexual (duplo sentido - sexually speaking). Possivelmente o jogador Zico seja conhecido, assim como a Copa do Mundo; a ideia aqui era usar o exagero para acentuar a piada. "Cada cultura tem suas piadas e sua forma de criá-las, de contá-las, e inclusive de transmiti-las a outras culturas" ${ }^{\prime 157}$ (IRALA e FERNANDEZ, 2004, p. 4)

\begin{tabular}{|l|l|l|}
\hline Minutagem & Fala do personagem & Tradução/Legenda \\
\hline
\end{tabular}

\footnotetext{
156 "The language of sex reveals and reinforces important (underlying) cultural and ideological assumptions, and is probably the most powerful textualising device there is."

157 "Cada cultura tiene sus chistes y su forma de crearlos, de contarlos, e incluso, de transmitirlos a otras culturas."
} 


\begin{tabular}{|l|l|l|}
\hline $10: 55$ & $\begin{array}{l}\text { Honório: Você num teve } \\
\text { um negócio com essa mulher? } \\
\begin{array}{l}\text { Fernando: Dei uma } \\
\text { raquetada só. }\end{array}\end{array}$ & $\begin{array}{l}\text { Honório: -You had an affair } \\
\text { with her? }\end{array}$ \\
\hline
\end{tabular}

Nesse trecho curto, a piada - de cunho sexual - foi mantida na tradução, mas houve uma modulação, e a tradução foi suavizada, sem perder a menção sexual. O humor está também na rapidez da piada, 'en passant'; o gatilho do riso está no inesperado, no tratamento 'acidental' do encontro sexual. O acréscimo da palavra 'alright' na legenda deu ainda um tom mais informal.

\begin{tabular}{|c|c|c|}
\hline Minutagem & Fala do personagem & Tradução/Legenda \\
\hline $20: 00$ & $\begin{array}{l}\text { Honório: Mas isso é um } \\
\text { absurdo! Onde é que vai a } \\
\text { decência, hein? As conquistas } \\
\text { que a gente lutou tanto para } \\
\text { conseguir? Foi para isso que a } \\
\text { gente pediu "Diretas Já"? Foi } \\
\text { pra isso que morreu } \\
\text { Marighella? }\end{array}$ & $\begin{array}{l}\text { Honório: But it's } \\
\text { absurd!/Where is the decency? } \\
\text { Everything we conquered } \\
\text { with so much struggle? } \\
\text { Where's the trade union? } \\
\text { We claimed/for "Direct Elections } \\
\text { Now" for this? } \\
\text { Marighella died for this? }\end{array}$ \\
\hline
\end{tabular}

Aqui, a piada é bastante restrita a um universo conhecedor de certas referências culturais bem específicas, como o movimento Diretas Já ${ }^{158}$ e o político e guerrilheiro Carlos Marighella ${ }^{159}$. Conhecer o histórico vai salientar o humor irônico do comentário de Fernando. Nos casos de comédias inteligentes, “que jogam com a

\footnotetext{
${ }^{158}$ Diretas Já foi um movimento civil de reivindicação por eleições presidenciais diretas no Brasil, ocorrido em 1983-84.

${ }^{159}$ Carlos Marighella, nascido em Salvador em dezembro de 1911, foi um político e guerrilheiro brasileiro, um dos principais organizadores da luta durante a ditadura militar; chegou a ser considerado o inimigo "número um" da ditadura.
} 
ironia e as sutilezas do humor"160 (IRALA e FERNANDEZ, 2004, p. 7), a estratégia tradutória precisa buscar um equilíbrio entre fidelidade e efetividade.

\begin{tabular}{|l|c|c|}
\hline Minutagem & Fala do personagem & Tradução/Legenda \\
\hline $50: 32$ & $\begin{array}{c}\text { Vitoria: Eu sempre falei } \\
\text { para você tocar a sua vida. } \\
\text { Fernando: Vitória, a } \\
\text { minha vida não é um trombone. }\end{array}$ & $\begin{array}{c}\text { Vitoria: I always told you/to } \\
\text { carry on with your life. }\end{array}$ \\
& $\begin{array}{c}\text { Fernando: Vitoria,/it's not } \\
\text { as simple as that. }\end{array}$ \\
\hline
\end{tabular}

Nesse trecho há uma simplificação da referência humorística, e a piada é anulada. O problema que se apresenta aqui é que, mais tarde (ver trecho abaixo), a mesma referência se repetirá. O tradutor/legendador manteve o jogo de palavras, mas a tradução não tem esse gatilho de humor.

\begin{tabular}{|c|c|c|}
\hline Minutagem & Fala do personagem & Tradução/Legenda \\
\hline $52: 06$ & $\begin{array}{l}\text { Advogado: } \\
\text { cliente quer que a parte } \\
\text { contrária toque a vida dele. } \\
\text { Advogada: Meu cliente } \\
\text { já falou que a vida dele não é } \\
\text { um trompete. } \\
\text { Fernando: Trombone... }\end{array}$ & $\begin{array}{l}\text { Lawyer: My client wants } \\
\text { the other part/to move on with his } \\
\text { life. } \\
\text { Lawyer 2: My client has } \\
\text { already said that/it's not as easy as } \\
\text { that. } \\
\text { Fernando: Simple... }\end{array}$ \\
\hline
\end{tabular}

A resolução da piada, ainda que inventiva, não tem uma referência humorística e, ainda que a paráfrase tenha sido coerente, o humor acabou sendo minimizado. Segundo Zabalbeascoa (apud LIBERATTI, 2011, p. 232),

existem várias características que podem trazer empecilhos à tradução. A principal delas é a dificuldade de manutenção do efeito cômico quando piadas são transpassadas de uma língua a outra, devido a diferenças nos conhecimentos prévios das audiências do texto fonte e do texto da tradução; diferenças de valores culturais, costumes e tradições, contexto profissional do tradutor, etc.

160 “...que juegan con la ironía y las sutilezas del humor.” 


\begin{tabular}{|c|c|c|}
\hline Minutagem & Fala do personagem & Tradução/Legenda \\
\hline $58: 55$ & $\begin{array}{l}\text { Alana: Fom? Quem } \\
\text { morreu? } \\
\text { Afonsinho: Alana? } \\
\text { Alana: Que que } \\
\text { aconteceu? } \\
\text { Afonsinho: Tava vendo } \\
\text { um filme agora e acabei } \\
\text { sentindo saudade... } \\
\text { Alana: Afonso, é o } \\
\text { seguinte: só me liga a essa hora } \\
\text { se for caso de polícia ou de } \\
\text { AIDS, tá legal? São } 5 \text { da } \\
\text { manhã! Romantismo aqui é só } \\
\text { depois do meio-dia! }\end{array}$ & $\begin{array}{l}\text { Alana: -Fom? Who died? } \\
\text { Afonsinho: -Alana? } \\
\text { Alana: What happened? } \\
\text { Afonsinho: I was watching } \\
\text { a movie/and ended up missing you } \\
\text { badly... } \\
\text { Alana: Afonso, only call me } \\
\text { at this time/if it's a case for the } \\
\text { police or of AIDS. } \\
\text { It's } 5 \text { am!/I can be romantic } \\
\text { only after midday! }\end{array}$ \\
\hline
\end{tabular}

A alusão sexual também está implícita aqui, além do humor e da ironia, mais explícitos. A ironia - situacional - está no fato que Afonso está ligando às 5 da manhã para uma garota de programa por quem se apaixonou e ela diz que só e caso de polícia ou AIDS. Garmendia (2014, p. 656) argumenta que enunciados irônicos podem ter vários padrões e ser colocados de diversas formas.

Assim, o que une todos os exemplos de ironia, o que é essencial e básico para a comunicação irônica, é algo bastante simples e básico: um conflito explícito entre o que o emissor quer comunicar e o que ele aparentemente está apresentando. Isso é algo que se encontra em qualquer enunciado irônico. ${ }^{161}$

\begin{tabular}{|l|l|l|}
\hline Minutagem & Fala do personagem & Tradução/Legenda \\
\hline
\end{tabular}

161 "Thus, what ties together all instances of irony, what is essential and basic for ironic communication, issomething rather simple and basic: an overt clash between what the speaker intends to communicate and what she is apparently putting forward. This is something that will be found beneath every ironic utterance." 


\begin{tabular}{|l|l|l|}
\hline 1:10:00 & $\begin{array}{l}\text { Afonsinho: Aí, cola } \\
\text { velcro do caralho. }\end{array}$ & \multicolumn{1}{c|}{$\begin{array}{l}\text { Afonsinho: -Fucking lesbo. } \\
\text { Mulher: O quê? Mulher }\end{array}$} \\
& $\begin{array}{l}\text { Woman: -What? } \\
\text { que cola velcro é a puta da tua } \\
\text { mãe! }\end{array}$ & $\begin{array}{l}\text { Lesbo is your/fucking } \\
\text { mother. }\end{array}$ \\
\hline
\end{tabular}

Esse trecho seria o mais pesado em termos de utilização de linguagem sensível, no caso, obscena. A tradução passou por uma adaptação e substituição (cola velcro por lesbo e do caralho por fucking) e a fala original tem mais carga semântica. No entanto, o gestual e a resolução da cena (primeiro o espanto de o comentário ter recebido uma resposta e depois a gargalhada) diluíram essa carga. Ainda há muito antagonismo quanto ao uso da palavra 'fucking', principalmente por expressar emoções como raiva ou frustração. Os palavrões que fazem referência a sexo ou excreções são os mais censurados e, ao mesmo tempo, os mais utilizados.

Em inglês, há o verbo 'to velcro', que seria 'juntar as áreas púbicas durante sexo lésbico'. Entretanto, o tradutor/legendador optou por um termo mais conhecido e, nesse caso, mais brando. Poderia ser um tipo de auto-censura, muito comum quando o tradutor se depara com algo que não considera 'aceitável' do ponto de vista social ou pessoal. Segundo Santaemilia (2008, p. 221), "auto-censura é uma batalha ética individual entre o eu e o contexto". ${ }^{162}$ É um controle auto-imposto que pode se revelar em traduções parciais, minimizações ou omissões de termos sexuais. Não é exatamente o caso aqui, pois a linguagem sexual foi traduzida, mas "historicamente, a linguagem sexual é uma área sensível""163 (id., p. 256) que se refere a todo um arcabouço de ideias e valores do tradutor:

A auto-censura pode incluir todas as formas imagináveis de eliminação, distorção, redução, desajuste, infidelidade e assim por diante. Há exemplos grosseiros de auto-censura, cujo modelo ideológico é bastante óbvio ${ }^{164}$ (SANTAEMILIA, 2008, p. 224).

\footnotetext{
162 “...self-censorship is an individual ethical struggle between self and context."

163 "Historically, sex-related language has been a highly sensitive area."

164 "Self-censorships may include all the imaginable forms of elimination, distortion, downgrading, misadjustment, infidelity, and so on. There are blunt and unrefined instances of self-censorship, whose ideological design is pretty obvious."
} 


\begin{tabular}{|c|c|c|}
\hline Minutagem & Fala do personagem & Tradução/Legenda \\
\hline $1: 37: 11$ & 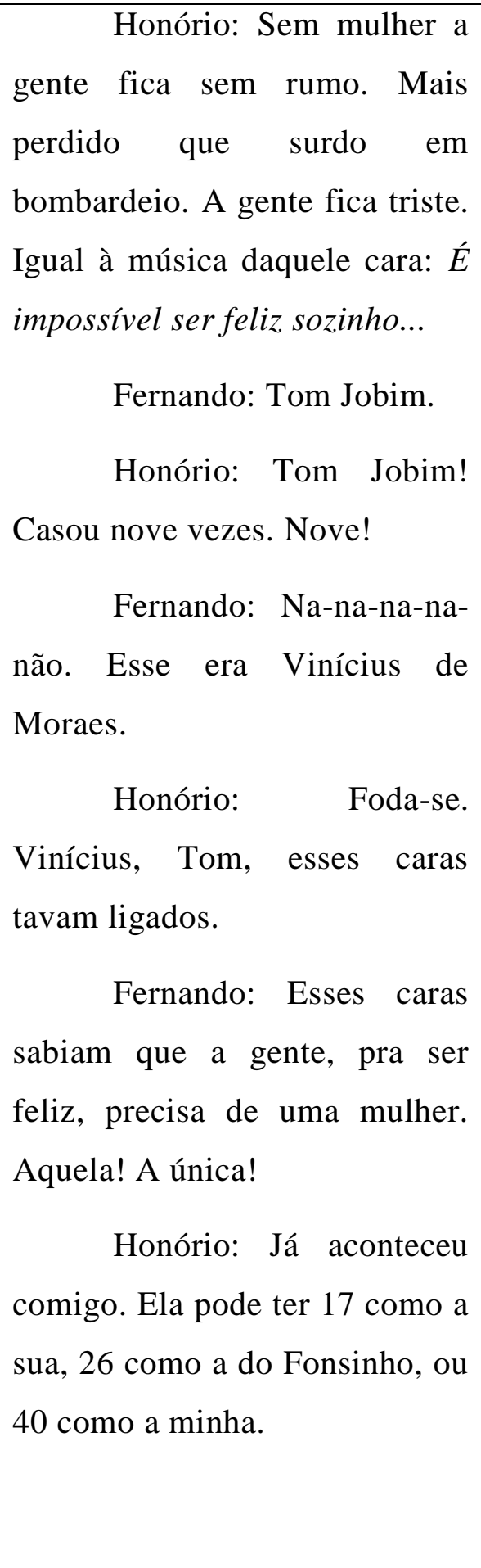 & 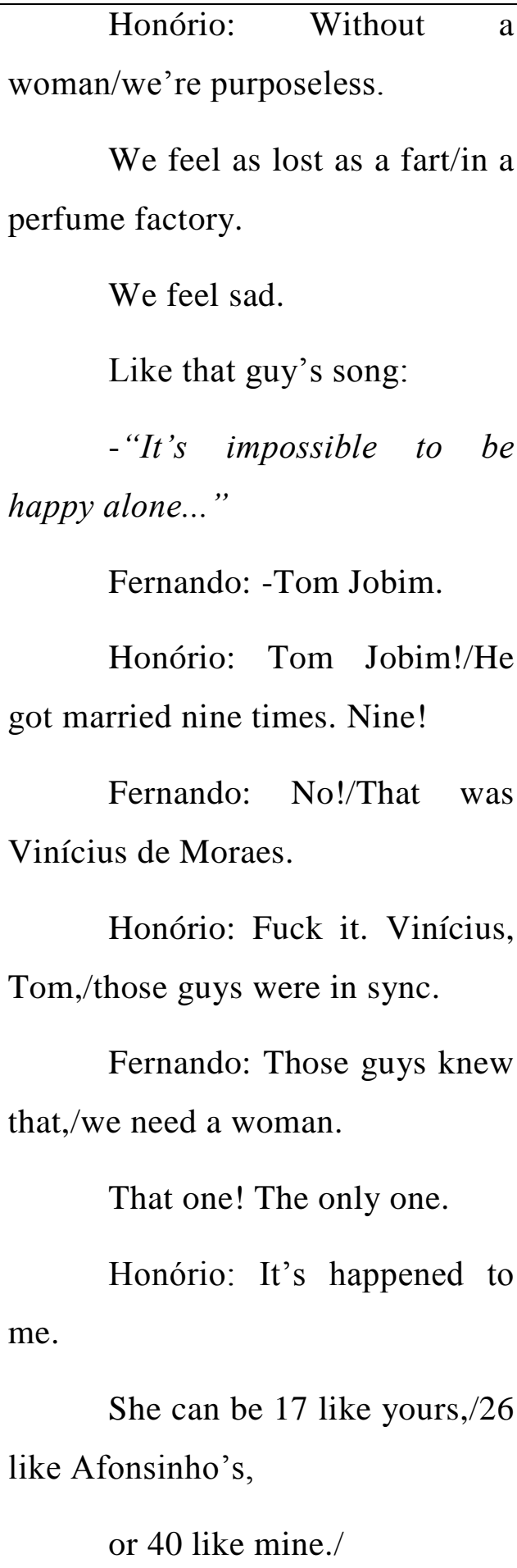 \\
\hline Minutagem & Fala do personagem & Tradução/Legenda \\
\hline $1: 37: 48$ & $\begin{array}{l}\text { Honório: Sem elas, a } \\
\text { gente não consegue nem } \\
\text { desenhar um "O" com o cu na }\end{array}$ & $\begin{array}{l}\text { Honório: Without them, } \\
\text { we can't even draw an }\end{array}$ \\
\hline
\end{tabular}




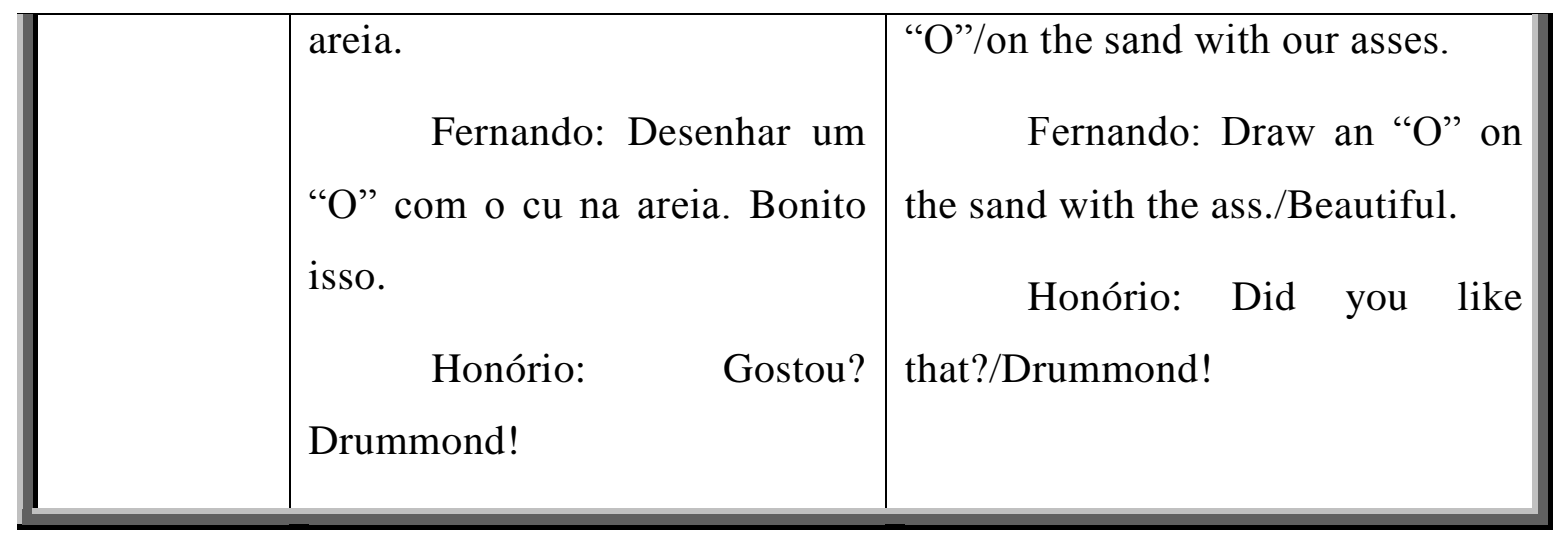

Já no final do filme, os mesmos amigos se encontram, e o discurso é bem diferente do inicial; a ironia fica patente, como uma 'contradição inferida' ${ }^{165}$, pois não há uma menção ao que foi dito no início. O tom melancólico acrescenta à ironia velada, mas a característica mais marcante deste trecho é o humor. Na primeira parte, há a substituição da expressão 'mais perdido que surdo em tiroteio' ${ }^{166}$ por 'as lost as a fart in a perfume factory ${ }^{167}$, com efeito cômico igual - ou talvez um pouco mais acentuado na legenda; na segunda parte, a tradução foi literal com transposição/conversão estrutural que, segundo Panek (2009, p. 46) é "uma mudança de categoria gramatical"168. Houve apenas a inversão das locuções adverbiais, e a intenção humorística permaneceu a mesma.

As referências aos poetas/músicos Tom Jobim, Vinícius de Moraes e Drummond $^{169}$ foram mantidas, sem alterações ou explicações. Levando-se em consideração que o público que assiste um filme brasileiro com legendas em inglês é

\footnotetext{
${ }^{165}$ Segundo Alba-Juez (2014, p. 1), "uma característica permanente e sempre presente na ironia verbal, contradição inferida, que deve ser diferenciada da contradição pura, direta (não-inferida) e também da negação indireta, pois uma contradição que é expressa diretamente não pode ser considerada irônica (já que não tem o componente crucial: inferência), e uma negação indireta pode ou não ser irônica (dependendo da situação), e por isso não pode ser considerada uma característica permanente do fenômeno. ["a permanent and ever-present feature of verbal irony, namely, inferred contradiction, which has to be distinguished from plain, direct (non-inferred) contradiction as well as from indirect negation, for a contradiction which is directly expressed cannot be interpreted as ironical (since it lacks a crucial component: inference), and an indirect negation may or may not be ironic (depending on the situation), and thus cannot be considered a permanent feature of the phenomenon.”]

${ }^{166}$ A expressão também pode ser: mais perdido que cego em tiroteio.

${ }^{167} \mathrm{Em}$ tradução literal, mais perdido que um peido numa fábrica de perfume.

168 "a change in grammatical category."

${ }^{169}$ Tom Jobim - Antônio Carlos Brasileiro de Almeida Jobim (Rio de Janeiro, 25 de janeiro de 1927 Nova York, 8 de dezembro de 1994) foi compositor, maestro, pianista, cantor, arranjador e violonista, um dos criadores e principais forças do movimento da bossa nova. Vinícius de Moraes - Marcus Vinícius de Moraes (Rio de Janeiro, 19 de outubro de 1913 - Rio de Janeiro, 9 de julho de 1980) foi diplomata, dramaturgo, jornalista, poeta e compositor brasileiro, com vasta obra passando pela literatura, teatro, cinema e música. Drummond - Carlos Drummond de Andrade (Itabira, 31 de outubro de 1902 - Rio de Janeiro, 17 de agosto de 1987) foi poeta, contista e cronista, considerado por muitos o mais influente poeta brasileiro do século XX. (fonte: www.wikipedia.org)
} 
um público único, que busca um diferencial no entretenimento, é de se esperar que conheçam - ou se interessem e procurem saber mais sobre - os brasileiros famosos citados. O nome de Drummond poderia ser precedido por 'the poet', facilitando até a busca posterior.

O filme termina em festa e não há diálogos, há uma música (Erasmo Carlos Sou uma criança, não entendo nada) que, por caracterizar o momento que os personagens estavam passando, recebeu status de personagem e também foi legendada. Há algumas limitações para a tradução e legendagem de músicas; em geral, as letras não contribuem diretamente para a história.

Mas se a música for longa, os espectadores que não entenderem as palavras vão, no mínimo, querer saber o que ela significa, e podem até ficar muito frustrados. Sabe-se que se os diretores decidem incluir uma música, isso geralmente é feito com um propósito, e os espectadores que não entendem a letra não podem compreender a relevância. Então, na dúvida, legende. ${ }^{170}$ (DÍAZ-CINTAS e REMAEL, 2007, p. 208)

\footnotetext{
170 "But if a song is rather long, viewers who do not understand the words will start wondering about their meaning at best, and become seriously frustrated in the worst case. It is safe to say that if directors decide to include a song, this is usually done for a purpose, and viewers who do not understand the words cannot estimate their relevance. So, when in doubt: subtitle."
} 


\title{
CONSIDERAÇÕES FINAIS - E o Vento Levou ${ }^{171}$
}

\author{
As ideias estão contidas e praticamente engastadas nas palavras \\ como pedras preciosas num anel. Elas se incorporam às palavras \\ como a alma ao corpo, de tal modo que constituem um todo. \\ As ideias são, portanto, inseparáveis das palavras, e se \\ se separarem delas, não serão mais as mesmas.
}

Giacomo Leopardi

A multiplicidade de estímulos origina uma miríade de interpretações, sutilezas, singelezas e pormenores em cada linguagem, em cada forma de comunicação. Tais formas de comunicação se entrelaçam na multimodalidade partilhada, num entusiasmado retorno a Babel, ou talvez a uma Babel às avessas, onde a necessidade de comunicação determina a busca por todas as texturas e nuances da tradução. Tradução que é intermediada por diversos canais em diferentes contextos e culturas, todas ricas e complexas. A Babel se expande e surge a necessidade de mediação: o específico que se torna geral; o particular que é compartilhado, sem perder a originalidade. A Babel demanda legendação.

Dentro desse universo da linguagem que busca tradução e legendação, há tantas intenções quanto há modos de expressão: a intenção do riso, da zombaria, da ironia, das palavras que preferem calar, e por aí vai. Pormenorizando ainda mais, como essa linguagem de humor e de ironia se apresenta no composto multimodal de um filme legendado?

As legendas limitam, mas também possibilitam. Possibilitam que um visite e interprete o outro, porque o processo só acontece se há um emissor e um receptor.

\footnotetext{
O que importa aqui deixar claro é o reconhecimento da recepção, do outro, como condição de qualquer produção de linguagem, oral ou escrita - tanto aquela recepção que é real, quanto a que é suposta; tanto aquela em que a pessoa do receptor e a do autor se distinguem, como aquela em que coincidem. (ROSAS, 2002, p. 26)
}

Levando-se em consideração o escopo deste estudo, o humor em todas as suas manifestações cabe no espaço exíguo da legenda porque há diversos

171 ...E o vento levou (Gone with the wind) é um filme de 1939 que retrata o sul estadunidense do século XIX, narrando a história de Scarlett O'Hara, filha de temperamento forte do proprietário de uma plantação, e sua perseguição romântica a Ashley Wilkes, que é casado com sua prima, Melania Hamilton, para se casar com Rhett Butler. A história é contada a partir da perspectiva dos sulistas brancos. 
procedimentos, técnicas e estratégias que o legendador - ou legendista - vai utilizar para encaixar as ideias, mesmo que tais estratégias sejam inconscientes, ou seja, não sejam pensadas a priori. Assim também acontece com a linguagem sensível, a que se manifesta em tantas falas, ou em alguns silêncios.

Há muitos ganhos: as línguas se aprimoram com o contato, e a tradução cria essa ponte. Há também conflitos, claro; alguns momentos em que o espectador - e leitor das legendas - sente a ausência do "retrato da fala" (RIDD, apud MOREIRA, 2013, p. 4). Momento de pensar lateral e criativamente, e utilizar estratégias que entrelacem as línguas, as culturas, as ideias, os valores. Na possibilidade da tradução literal, essa foi a escolha, já que não há divergências extremas de sistemas linguísticos, de estilo ou de realidade extralinguística entre as culturas estudadas. No entanto, a escolha mais descomplicada pela tradução literal também demonstra exiguidade de intermediação, já que não houve uma intencionalidade; nas palavras de Ridd (1996, p. 478), as legendas, "como instrumento de intermediação entre o discurso da trilha do filme e o espectador, poderão tornar elementos implícitos na língua de partida explícitos na língua meta, para facilitar e assegurar o entendimento". Mas diversos também foram os momentos em que a escolha recaiu em substituições, transferências, decalques, condensações, deslocamentos, explicitações e até omissões. E como humor com humor se resolve, os eventuais conflitos tradutórios também foram resolvidos. E as legendas foram as convenientes ‘intrusas' que intermediaram a comunicação entre as línguas e culturas. Nas palavras de Gottlieb (1994, p. 101),

\footnotetext{
A legendagem é um anfíbio: nada com a corrente da fala, definindo o ritmo da recepção; pula em intervalos regulares, permitindo que um novo texto seja lido; e sobrevoando a paisagem audiovisual, não se mistura às vozes humanas da paisagem: em vez disso, oferece ao público uma visão panorâmica do cenário. $^{172}$
}

Cada um dos sete filmes analisados nesse estudo apresentou, nas legendas, processos criativos de tradução de humor e linguagem sensível, manifesta em ironia, sarcasmo, linguagem sexual ou obscena, e afins. As estratégias tradutórias seguem os postulados das teorias funcionalistas da tradução, que buscam o propósito, a

\footnotetext{
172 "Subtitling is an amphibian: it flows with the current of speech, defining the pace of reception; it jumps at regular intervals, allowing a new text chunk to be read; and flying over the audiovisual landscape, it does not mingle with the human voices of that landscape: instead it provides the audience with a bird's-eye view of the scenery."
} 
finalidade da tradução, aproximando o processo cada vez mais do usuário, ou seja, o espectador, o leitor da legenda. Nessa reflexão, um registro é importante: em nenhum dos DVDs o profissional tradutor/legendador foi identificado, esse profissional conhecedor das

\begin{abstract}
diferenças e semelhanças dos dois discursos e tem que saber conjuminar as necessidades das legendas - enquanto discurso escrito que procura refletir um discurso oral - com as necessidades do espectador que se esforça para, concomitantemente, ler as legendas, entender o filme e desfrutar da beleza plástica da filmagem. Munido desta informação, o legendador pode avançar com maior segurança sobre a corda bamba que sustenta este ofício difícil mas intrigante que reúne equilíbrio linguístico e sensibilidade estética - arte, enfim (RIDD, 1996, p. 482).
\end{abstract}

Seria interessante que esse profissional tivesse mais visibilidade e reconhecimento; afinal, ele abre as janelas para que o mundo tenha mais colorido.

A tradução não é apenas uma janela aberta a outro mundo, ou mera retórica. Mais do que isso, a tradução é um canal aberto, frequentemente com certa relutância, através do qual influências externas podem penetrar a cultura nativa, desafiá-la, e até contribuir para subvertê-la. ${ }^{173}$ (LEFEVERE, 1992, apud DINIZ, 2013, p. 29)

\footnotetext{
173 "Translation is not just a window open on another world, or some such pious platitude. Rather translation is a channel opened, often not without a certain reluctance, through which foreign influences can penetrate the native culture, challenge it, and even contribute to subverting it."
} 


\section{REFERÊNCIAS BIBLIOGRÁFICAS - O silêncio dos inocentes ${ }^{174}$}

ABNT. Associação Brasileira de Normas Técnicas.

ALBA-JUEZ, Laura. Irony as inferred contradiction. Vestnik of People's Friendship University of Russia. Linguistics Series, nº 4, 2014. 140-153.

ALVAREZ, Roman e VIDAL, Carmen Perez (eds.). Translation, power, subversion. Clevedon: Multilingual Matters, 1996. 164p.

ATTARDO, Salvatore. Translation and humour: an approach based on the general theory of verbal humour (GTVH). The Translator, Volume 8, № 2, 2002. 173-194.

BANNON, D. The Elements of Subtitles. Edição Revisada e Expandida. Lulu.com, 2010. 168p.

BARBOSA, Heloisa Gonçalves. Procedimentos técnicos da tradução. Uma nova proposta. Campinas, SP: Editora Pontes, 2007. 128 p.

BRANCO, Sinara de Oliveira. Tradução intersemiótica e legendagem: Adaptação de linguagens para compreensão de culturas. Cadernos de Letras da UFF. Tradução, $n^{\circ}$ 48. 2013. 91-112.

CHIARO, Delia (ed.). Translation, humour and the media. Londres: Continuum International Publishing Group, 2012. 259p.

CONZ, Jaqueline. Ironia Verbal: Teorias e Considerações. 2010. Monografia de Graduação. Universidade Federal do Rio Grande do Sul.

CUÉLLAR, Sergio Bolaños. Gregory Rabassa's Views on Translation. Forma y Función, volume 24, nº1, 2011. Disponível em:

http://www.revistas.unal.edu.co/index.php/formayfuncion/article/view/29255/36090

DE ROSA, Gian Luigi. Dublando humor nos cartoons: Chico Bento na Itália.

Comunicação. X Congresso da Associação Internacional de Lusitanistas. Universidade do Algarve, julho de 2011.

DÍAZ-CINTAS, Jorge Díaz; REMAEL, Aline. Audiovisual translation: subtitling. Translation Practices Explained, v.11. Manchester: St. Jerome Publishing, 2007. 280 p.

DÍAZ-CINTAS, Jorge Díaz; ANDERSON, Gunilla (eds.). Audiovisual translation: language transfer on screen. Basingstoke: Palgrave Macmillan, 2009. 271p.

DINIZ, Thaïs Flores Nogueira. A new approach to the study of translation: from stage to screen. Disponível em: dialnet.unirioja.es/descarga/articulo/4925536.pdf

${ }^{174}$ O silêncio dos inocentes (Silence of the lambs) é um filme de 1991, no qual a agente do FBI Clarice Starling (Jodie Foster) é ordenada a encontrar um assassino que arranca a pele de suas vítimas. Para entender como ele pensa, ela procura o perigoso psicopata, Hannibal Lecter (Anthony Hopkins), encarcerado sob a acusação de canibalismo. 
ENOMOTO, Simone. Teoria da equivalência dinâmica versus paradigma funcionalista: pontos de aproximação e distanciamento. Monografia. Curitiba, 2005.

FERREIRA, Luciane Corrêa; GLODNADEL, Marcos; KRAUSPENHAR, Daiana Grings. A tradução da metáfora: uma abordagem cognitiva. Revista Virtual de Estudos da Linguagem - ReVEL, Volume 5, nº 8, 2007.

GAO, Chunming. A sociolinguistic study of English taboo language. Theory and Practice in Language Studies, Volume 3, nº 12, 2013.2310-2314.

GARMENDIA, Joana. The clash: humor and critical attitude in verbal irony. Humor, 27 (4), 2014. 641-659.

GENTZLER, Edwin. Teorias contemporâneas da tradução. São Paulo: Editora Madras, 2009, 296p. Tradução: Marcos Malvezzi.

GEORGAKOPOULOU, Panayota. Subtitling and globalisation. The Journal of Specialised Translation, Volume 6, Julho de 2006.

. Subtitling for the DVD industry. In: DÍAZ-CINTAS, Jorge e ANDERSON, Gunilla (eds.). Audiovisual translation: language transfer on screen. Basingstoke: Palgrave Macmillan, 2009. 21-35.

GOROVITZ, Sabine. Os labirintos da tradução. Brasília: Editora Universidade de Brasília, 2006. 78p.

GOTTLIEB, Henrik. Subtitling: diagonal translation. Perspectives. Volume 2, janeiro 1994. 101-121.

. Texts, translation and subtitling : in theory, and in Denmark. Translators and Translations. The Danish Institute at Athens: Aarhus Universitetsforlag, 2001, p. 149-192.

. Subtitles and international anglification. Nordic Journal of English

Studies. Volume 3, nº1, 2004. Disponível em

http://ojs.ub.gu.se/ojs/index.php/njes/article/view/244. Acesso em: 15/05/2015.

. Multidimensional translation: semantics turned semiotics. MuTra $2005-$

Challenges of Multidimensional Translation: Conference Proceedings, 2005. Disponível em

http://www.euroconferences.info/proceedings/2005_Proceedings/2005_Gottlieb_Henrik .pdf. Acesso em: 15/05/2015.

GUZMÁN, María Constanza. Rabassa and the "Narrow Act": between possibility and an ethics of doubt. TTR: traduction, terminology, redaction, volume $21, \mathrm{n}^{\circ} 1,2008$. 211-239. 
HAJMOHAMMADI, Ali. The viewer as the focus of subtitling. Translation Journal, Volume 8, No 4, Outubro 2004. Disponível em:

http://translationjournal.net/journal/30subtitling.htm. Acesso em: 03/08/2012.

HEMPELMANN, Christian F. Script opposition and logical mechanism in punning. Humor, volume 17, nº 4, 2004. 381-392.

INTERNET ENCYCLOPEDIA OF PHILOSOPHY.

http://www.iep.utm.edu/humor/\#H1

IRALA, Jana Cuéllar; FERNÁNDEZ, Andrea García-Falces. Cultura y humor: traductores al borde de un ataque de nervios. Linguax, 2004.

KAPOGIANNI, Eleni. Irony via “Surrealism”. Em DYNEL, Marta (ed.). The Pragmatics of Humour across Discourse Domains. 2011. 51-68.

KARAMITROGLOU, Fotios. A proposed set of subtitling standards in Europe. Translation Journal, Volume 2, nº 2, 1998.

. Towards a methodology for the investigation of norms in audiovisual

translation. Amsterdã e Atlanta, GA: Rodopi, 2000. 300 p.

KRIKMANN, Arvo. Contemporary linguistic theories of humour. Folklore: Electronic Journal of Folklore, volume 33, 2006. 27-58.

LAGES, Susana Kampff. Walter Benjamin: tradução e melancolia. São Paulo: Editora da Universidade de São Paulo, 2007. 258 p.

LEAL, Alice. Funcionalismo e tradução literária: o modelo de Christiane Nord em três contos ingleses contemporâneos. Scientia Traductionis, 2006.

LEIVAS WAQUIL, Marina. Unidades fraseológicas especializadas e técnicas tradutórias. Debate Terminológico, n. 9, novembro 2013. 56-81.

LIBERATTI, Elisângela. Legendagem de series humorísticas: um estudo da tradução do humor na série americana "Friends". Scientia Traductionis, 2011.

MARTÍN, Francisco José. La teoría de la traducción en Ortega. Cuadernos AISPI, 1995. Disponível em: http://cvc.cervantes.es/literatura/aispi/pdf/06/06_245.pdf

MARTINEZ, Sabrina Lopes. Tradução para legendas: Uma proposta para a formação de profissionais. Tese de Mestrado. Pontifícia Universidade Católica do Rio de Janeiro - PUC, 2007.

MARTINS, Raíra Verenich; AMORIM, Lauro Maia. Legendagem e dublagem: diferenças na tradução do humor. Traduzires, 2013. 101-128.

MATEO, Marta. A tradução da ironia. Cadernos de Tradução. Universidade Federal de Santa Catarina, volume 1, n²5, 2010. 197-220. 
MEIRA, Elinaldo S. Aos que tem Jacu, aos que tem Jacó ou aos que tem jaú e aos que tem socó: Caipira, Identidade e Cinema de Documentário. XII Conferência Brasileira de Folkcomunicação. 2009.

MOREIRA, Shirley Tiara de Souza. O auto da compadecida: o humor nordestino legendado. Revista Inventário, 12ª ed., Universidade Federal da Bahia, 2013.

NORD, Christiane. Defining translation functions: the translation brief as a guideline for the trainee translator. Ilha do Desterro, Universidade Federal de Santa Catarina, $\mathrm{n}^{\mathbf{o}}$ $33,1997.41-55$.

Translating as a purposeful activity: a prospective approach.

TradTerm, 2005. Disponível em:

http://www.revistas.usp.br/tradterm/article/view/49673

Translating as a purposeful activity. Translation Theories Explained.

Nova York: Routledge, 2014. 154p.

ORSI, Vivian. Tabu e preconceito linguístico. ReVEL, Volume 9, nº17, 2011.

PANEK, Magdalena. Subtitling humor: the analysis of selected translation techniques in subtitling elements containing humor. Dissertação de mestrado. Alemanha: GRIN, 2009. $62 \mathrm{p}$.

PEDERSEN, Jan. How is culture Rerndered in subtitles? MuTra - Challenges of Multidimensional Translation: Conference Proceedings, 2005.

PELSMAEKERS, Katja; VAN BESIEN, Fred. Subtitling irony: Blackadder in Dutch. The translator, Volume $8, \mathrm{n}^{\mathrm{o}}$ 2, 2002. 241-266.

PEREIRA, Ordilei Dias. A Marvada Carne: uma epopeia caipira. Plural, Revista do Programa de Pós-Graduação em Sociologia da USP, São Paulo, nº14, 2007. 33-50.

POSSENTI, Sírio. Os humores da língua: análises linguísticas de piadas. Campinas, SP: Mercado das Letras, 1998. 152 p.

Humor, língua e discurso. São Paulo: Editora Contexto, 2010. 185 p.

PYM, Anthony. Vinay and Darbelnet and the politics of translation solutions. Agosto de 2014. Disponível eletronicamente em: http://usuaris.tinet.cat/apym/online/translation/2014_vinay_darbelnet.pdf

RASKIN,Victor; HEMPELMANN, Christian F.; TAYLOR, Julia M. How to understand and assess a theory: the evolution of the SSTH into the GTVH and now into the OSTH. Exemplar do Autor, 2009. Disponível em: < www.researchgate.net> Acesso em maio/2015.

RAW, Laurence. Translation, adaptation and transformation. Londres: Bloomsbury, 2013, 220p. 
REISS, Katharina; VERMEER, Hans. Towards a general theory of translational action: Skopos Theory Explained. Manchester: St. Jerome, 2013. 221p.

RIDD, Mark David. Legendagem: corda bamba entre o oral e o escrito. In MAGALHÃES, Izabel. As múltiplas faces da linguagem. Brasília: Editora Universidade de Brasília, 1996. 475-483.

RIETVELD, Jessica. The mind of a subtitler: translation strategies employed in subtitling crime and comedy. Dissertação de mestrado, Utrecht University, Holanda, junho/2008.

ROMERO, Joaquín Maria Aguirre (ed.). Humor y comunicación. Homenaje a Ana María Vigara. Espéculo Nº 50, Madri, janeiro 2013.

ROSAS, Marta. Tradução de humor: transcriando piadas. Rio de Janeiro: Lucerna, 2002. 128p.

. Por uma teoria da tradução do humor. Trabalhos de Tradução. DELTA, Volume 19: Especial, 2003. 133-161.

RUYTER, Serieke. Tradução de humor do português brasileiro para o neerlandês. Dissertação de Mestrado. Universidade Utrecht, Holanda. 2012.

SÁ, Emilene Lubianco. O auto da Compadecida - A dog's will: an analysis of the translation of idioms in the English subtitle. Trabalho de conclusão de curso. Universidade Federal de Santa Catarina - UFSC. Novembro de 2014.

SANTAEMILIA, José. Researching the language of sex: gender, discourse and (im)politeness. In: SANTAEMILIA, José (ed.). The language of sex: saying and not saying. Valencia: Universitat de València, 2005. 3-22.

. The translation of sex-related language: the danger(s) of self-

censorship(s). TTR: traduction, terminologie, redaction, volume $21, \mathrm{n}^{\mathrm{o}} 2,2008$.

. Amor y erotismo en Vargas Llosa y su traducción al inglés. Trans, $\mathrm{n}^{\circ}$ 14,

2010.

SARAJEVA, Şebnem Susam. The case study research method in translation studies.

The Interpreter and Translator Trainer, Volume 3, $\mathrm{N}^{\mathrm{o}}$ 1, 2009. 37-56.

SHIPLEY, Trajan. Towards a humour translation checklist for students of translation. Interlinguística, $\mathrm{n}^{\circ}$ 17, 2007. 981-988.

SILVA, Adriana Nunan do Nascimento. Homossexualidade e discriminação: o preconceito sexual internalizado. Tese de Doutorado. Pontifícia Universidade Católica do Rio de Janeiro, 2007.

SILVA, Nilson Roberto Barros. Um estudo sobre a recepção do humor traduzido.

Dissertação de Mestrado. Universidade Estadual do Ceará, 2006. 
SILVA, Regina Céli Alves. A linguagem anárquica de Roland Barthes em dois momentos: Aula e o Grau Zero da Escritura. Cadernos do CNFL, Rio de Janeiro: CIFEFIL, 2010. v. XIII. 291-302.

SUOJANEN, Tytti, KOSKINEN, Kaisa, TUOMINEN, Tiina. User-centered translation. Londres/Nova York: Routledge, 2015, 166p.

VANDAELE, Jeroen. "Each Time We Laugh": translated humour in screen comedy. In: Vandaele, Jeroen (ed.) Translation and the (re)location of meaning. Selected Papers of the CETRA Research Seminars in Translation Studies, 1994-1996. Leuven: CETRA, 237-272.

. Humor in translation. The Translator, Volume 8, Number 2, 2002: Special Issue. Translating Humour. 147-152.

2011. 180-183.

Wordplay in translation. Handbook of Translation Studies, volume 2,

VEIGA, Maria José. Linguistic mechanisms of humour subtitling. Poster. $4^{\mathrm{o}}$ Fórum de Partilha Linguística. Universidade Nova de Lisboa, outubro de 2009.

YIN, Robert K. Estudo de caso: planejamento e métodos. Tradução Daniel Grassi. $2^{\mathrm{a}}$ ed. Porto Alegre: Bookman, 2001, 205p.

ZABALBEASCOA, Patrick. Factors in dubbing television comedy. Perspective Studies in Translatology. Janeiro 1994. 89-99.

Translating audiovisual screen irony. In GONZÁLEZ, Luis Pérez (ed.). Speaking in tongues: languages across contexts and users. English in the World Series, Edicions Universitat de València, 2003.

Fontes primárias

ARRAES, Guel. O auto da Compadecida. Globo Filmes. Manaus, 1999. DVD.

Lisbela e o prisioneiro. Petrobrás Distribuidora e Fox Home

Entertainment. Manaus, 2003. DVD.

. O bem amado. Petrobrás Distribuidora e Buena Vista Home

Entertainment. Manaus, 2010. DVD.

GOMES, Halder. Cine Holliúdy. Paris Filmes. Manaus, 2012. DVD.

JOFFILY, Felipe. E aí... Comeu? Paris Filmes. Manaus, 2012. DVD.

KLOTZEL, André. A Marvada Carne. Tatu Filmes. Manaus, 1985. DVD.

MACHADO, Sérgio. Quincas Berro D’Água. Buena Vista Home Entertainment. Manaus, 2010. DVD. 


\section{Bibliografia suplementar}

ALVES, Soraya Ferreira; ALENCASTRO, Karine Simões. A tradução de humor, cultura e valores na legendagem do filme "Como treinar seu dragão". Tradução \& Comunicação. Revista Brasileira de Tradutores, nº 26, 2013.

ARAÚJO, Vera Lúcia Santiago. Por que não são naturais algumas traduções produzidas para o meio audiovisual? Em Tradução \& comunicação. Revista brasileira de tradutores. SãoPaulo: Unibero, nº 10, 2001.

. O Processo de legendagem no Brasil. Revista do GELNE, Fortaleza, Volume $1 / 2, \mathrm{n}^{\mathrm{o}} 1,2006.156-159$.

ARGENTIM, Jéssica Pacharoni; ESQUEDA, Marileide Dias. A tradução para o inglês das variantes dialetais em Lisbela e o Prisioneiro. Tradução \& Comunicação. Revista Brasileira de Tradutores, $\mathrm{n}^{\circ}$ 24, 2012.

ARMELLINO, Elisa. Translating culture-bound elements in subtitling: an example of interlinguistic analysis: a scene from Scent of a Woman. Translation Journal, Volume $12, \mathrm{n}^{\mathrm{o}} 2$, abril de 2008.

ASSIS ROSA, Alexandra. Orality in Translation. Translation Studies, edição especial (ed. Paul Bandia), 2015. 1-17.

ATTARDO, Salvatore. Irony markers and functions: towards a goal-oriented theory of irony and its processing. Rask, Volume 12, 2000. 3-20.

AZEREDO, Patrícia Silva. E o Dadinho virou Lil'Dice: aspectos da domesticação e estrangeirização venutianas na versão para o inglês das legendas do filme Cidade de Deus. 2010. Monografia de Pós-Graduação em Tradução do Inglês. Universidade Gama Filho, Rio de Janeiro.

BEZERRA, Jacqueline Freitas. Verificação do modelo de tradução de Heloísa Gonçalves Barbosa na tradução da linguagem popular do romance Essa Terra, de Antônio Pires. Revista de Letras, n²1, Volume 1/2, janeiro/dezembro 1999.

BUCARIA, Chiara. Dubbing dark humour: a case study in audiovisual translation. Lodz Papers in Pragmatics 4.2, 2008.

CARVALHO, Carolina Alfaro. A tradução para legendas: dos polissistemas à singularidade do tradutor. Dissertação de mestrado. Rio de Janeiro: PUC-Rio. 2005. Disponível em: <http://www2.dbd.pucrio.br/pergamum/tesesabertas/0310729_05_pretextual.pdf $>$.

CHIARO, Delia. Verbally expressed humour on screen: reflections on translation and reception. The Journal of Specialised Translation. Volume 6, julho de 2006.

CHILE, Daniela M. Ioppi. The sitcom revisited: the translation of humor in a polysemiotic text. Cadernos de Tradução, Volume 1, no 4, 1999. Disponível em: https://periodicos.ufsc.br/index.php/traducao/article/view/5531/0 
DÍAZ-CINTAS, Jorge. Back to the future in subtitling. MuTra - Challenges of Multidimensional Translation: Conference Proceedings, 2005.

New Trends in Audiovisual Translation. Kindle Edition. Channel View Publications, 15 de setembro de 2011. 216 p.

DINIZ, Thaïs Flores Nogueira. Literatura e cinema: da semiótica à tradução cultural. Ouro Preto: Editora UFOP, 1999. 189p.

GEORGAKOPOULOU, Panayota. Challenges for the audiovisual industry in the digital age: the ever-changing needs of subtitler production. The Journal of Specialised Translation, Volume 17, janeiro de 2012.

GIOVANNI, Elena; ORERO, Pilar; AGOST, Rosa. Multidisciplinarity in audiovisual translation. MonTI, Volume 4, 2012. 9-22.

HAN, Chong; WANG, Kenny. Subtitling swearwords in reality TV series from English into Chinese: a corpus-based study of The Family. Translation \& Interpreting, Volume 6, n², 2014.

HIRSCH, Galia. Explicitations and other types of shifts in the translation of irony and humor. Target, Volume 23, $\mathrm{n}^{\circ}$ 2, 2011. 178-205.

KOGLIN, Arlene; OLIVEIRA, Sila Marisa. Variações terminológicas no campo Tradução Audiovisual: análise dos termos legendação, legendagem e tradução de/para legendas. Tradterm, São Paulo, volume 22, dezembro 2013.

KOMNACKÁ, Háta. Chesterman vs. Newmark: a comparison of two concepts of translation procedures. Trabalho de Conclusão de Curso. Universidade Masaryk, República Checa, 2009.

LAMMERTYN, María Ester. La traducción del humor verbal: traducciones al español de 'The Importance of Being Earnest' de Oscar Wilde. Transfer, Volume 1, maio 2010.

LAURIAN, Anne-Marie. Humour et traduction au contact des cultures. Meta: jornal des traducteurs, Volume 34, $\mathrm{n}^{\circ}$ 1, 1989. 5-14.

LEAL, Alice. Is the glass half empty or half full? Reflections on translation theory and practice in Brazil. Berlim: Frank \& Timme, 2014. 331 p.

LEAL, Christina Lachat. Visual perception and audiovisual translation: directed vision. MonTI, Volume 4, 2012.

LINDE, Zoe; KAY, Neil. The semiotics of subtitling. Manchester: St. Jerome, 1999.

LUIZ, Tiago Marques. A analítica bermaniana na tradução do humor dos coveiros de Hamlet. ARREDIA. Revista da Faculdade de Comunicação, Artes e Letras / UFGD. Volume 1, no 1, julho/dezembro 2012. 
MCLOUGHLIN, Laura Incalcaterra; BISCIO, Marie; MHAINNÍN, Máire Áine Ní (eds.). Audiovisual translation: subtitles and subtitling. New Trends in Translation Studies, Volume 9. Berlim: Peter Lang, 2011. 285p.

NIJLAND, Natalie. La subtitulación del humor en la serie Friends. Dissertação de Mestrado. Junho de 2012. Universidade Utrecht. Holanda.

NORD, Christiane. Loyalty and fidelity in specialized translation. Confluências: Revista de Tradução Científica e Técnica, nº 4, maio de 2006.

PALMA, Silvia. La traducción de los elementos culturales: el caso de Astérix y Mafalda. Encuentro Hispano-Francés de investigadores, Sevilla, 2005.

PEREGO, Elisa; DEL MISSER, Fabio; BOTTIROLI, Sara. Dubbing versus subtitling in young and older adults: cognitive and evaluative aspects. Perspectives: Studies in Translatology. Outubro de 2014. Disponível em: http://dx.doi.org/10.1080/0907676X.2014.912343

QUEIROZ, Bianca Rodrigues Bold. Tradução de humor: limites e possibilidades. Revista Ao Pé da Letra, Universidade Federal de Pernambuco, Volume 9, 2007.

REMAEL, Aline. Mainstream narrative film dialogue and subtitling. The Translator, Volume 9, $\mathrm{N}^{\mathrm{o}}$ 2, 2003. 225-247.

SAKELLARIOU, Panagiotis. The semiotic status of interlingual subtitling. Meta: Translators' Journal, Volume 57, n³, 2012. 677-693.

SPANAKAKI, Katia. Translating humor for subtitling. Translation Journal, Volume 11, No 2, Abril 2007. Disponível em: http://accurapid.com/journal/40humor.htm.

SZARKOWSKA, Agnieszka. The power of film translation. Translation Journal, Volume 9, N 2, Abril 2005. Disponível em: http://accurapid.com/journal/32film.htm.

VEIGA, Maria José Alves. O humor na tradução para legendagem: inglês/português. Tese de Doutorado. 2006. Universidade de Aveiro. Portugal.

ZOCOLI, Giovana Quadros. Traduzindo com humor: Um estudo de estilos e técnicas utilizadas nas traduções dos textos de Veríssimo e Fish. Projeto Final de Graduação, Universidade de Brasília, 2012. 